Csató László

\title{
A PÁROS ÖSSZEHASONLÍTÁSOKON ALAPULÓ RANGSOROLÁS MÓDSZERTANI ÉS ALKALMAZÁSI KÉRDÉSEI
}


Operációkutatás és Aktuáriustudományok Tanszék

Témavezetők:

Dr. Fülöp János Ph.D.

Dr. Temesi József CSc

(C) Csató László 


\section{Budapesti Corvinus Egyetem}

Általános és kvantitatív közgazdaságtan Doktori Iskola

A páros összehasonlításokon alapuló rangsorolás módszertani és alkalmazási kérdései

Doktori értekezés

Csató László 


\section{Tartalomjegyzék}

Ábrák jegyzéke

Táblázatok jegyzéke $\quad$ V

Köszönetnyilvánítás $\quad$ VII

1. Bevezetés 1

1.1. Célok és kihívások . . . . . . . . . . . . . . . . . . . . 1

1.2. Az értekezés szerkezete . . . . . . . . . . . . . . . . . . 2

1.3. Az értekezés eredményei . . . . . . . . . . . . . . . . 5

1.4. Jelölések . . . . . . . . . . . . . . . . . . . . . . . . . . . 6

2. A páros összehasonlításon alapuló rangsorolás modellje $\quad 7$

2.1. A rangsorolási probléma . . . . . . . . . . . . . 7

2.2. A mérkőzésmátrix gráf reprezentációja . . . . . . . . . . . . . . . 14

2.3. A rangsorolás különbözö megközelítései . . . . . . . . . . . . . . . 15

2.4. A pontozási eljárások axiomatikus szempontú áttekintése . . . . . . 19

2.5. Összegzés . . . . . . . . . . . . . . . . . . . 22

3. Pontozási eljárások 24

3.1. Néhány pontozási eljárás . . . . . . . . . . . . . . . . . . . . 24

3.2. A legkisebb négyzetek módszeréről _ . . . . . . . . . . . . 27

3.3. A megoldás egyértelmüsége . . . . . . . . . . . . . . . . . . . 31

3.3.1. A legkisebb négyzetek módszere . . . . . . . . . . . . . . . . . 31

3.3.2. Más pontozási eljárások . . . . . . . . . . . . . 33

3.4. Összegzés . . . . . . . . . . . . . . . . . 34

4. A legkisebb négyzetek módszerének gráf interpretációja 36

4.1. Az értékelővektor alternatív számítása . . . . . . . . . . . . . . . 37

4.2. Az eljárás iteratív felbontása . . . . . . . . . . . . . . . . . 38

4.2.1. A dekompozíció levezetése . . . . . . . . . . . . . . 38

4.2.2. Az irodalom hasonló eredményei . . . . . . . . . . . . . . . . 41

4.2.3. Értelmezés . . . . . . . . . . . . . . . . . . . . . 42 
4.2.4. Összevetés más pontozási eljárásokkal . . . . . . . . . . . . . 44

4.3. A gráf interpretáció általánosítása . . . . . . . . . . . . . . . 46

4.4. Összegzés . . . . . . . . . . . . . . . . . . . . . . . . 48

5. A pontozási eljárások néhány tulajdonsága 50

5.1. A rangsor változatlanságának megkövetelése . . . . . . . . . . . . . 51

5.1.1. Függetlenség az elnevezésektől . . . . . . . . . . . . . . . 51

5.1.2. Technikai összefüggések . . . . . . . . . . . . . . . . 52

5.2. Multiplikatív transzformációk . . . . . . . . . . . . . 53

5.3. Additív transzformációk . . . . . . . . . . . . . . . . . 57

5.3.1. Összeadhatóság . . . . . . . . . . . . . . . . . 57

5.3.2. Az összeadhatóság finomítása . . . . . . . . . . . . . . . 60

5.4. Az eredménymátrix és a rangsorok kapcsolata . . . . . . . . . . . . 62

5.4.1. Eredmények megfordítása . . . . . . . . . . . . . 62

5.4.2. Kapcsolat a lineáris rendezéssel . . . . . . . . . . . . . . . 64

5.5. Az összehasonlítások megváltozásának hatása . . . . . . . . . . . 67

5.5.1. Függetlenség az irreleváns összehasonlításoktól . . . . . . . . . 68

5.5.2. Függetlenség a döntetlenektöl . . . . . . . . . . . . . . 71

5.6. Összegzés . . . . . . . . . . . . . . . . 76

6. Kapcsolat a pontszám módszerrel $\quad 79$

6.1. Karakterizáció a körmérkőzéses esetben . . . . . . . . . . . . . . . . 79

6.1.1. A szükséges tulajdonságok . . . . . . . . . . . . . . 79

6.1.2. Axiomatizáció . . . . . . . . . . . . . . 83

6.2. Pontozási eljárások a pontszám módszer kiterjesztéseként . . . . . . 84

6.2.1. Az ismert axiómák . . . . . . . . . . . . . . 84

6.2.2. Általánosítás . . . . . . . . . . . . . . . . . . . . 86

6.3. Összegzés . . . . . . . . . . . . . . . . . . . . 90

7. Rangsorolás svájci rendszerü sakk csapatversenyekben $\quad 92$

7.1. Svájci rendszerü sakk csapatversenyek rangsorolásának modellezése 92

7.1.1. Svájci rendszerü sakkversenyek jellemzői . . . . . . . . . . . . 93

7.1.2. A sorrend meghatározása pontozási eljárásokkal . . . . . . . . 95

7.2. Alkalmazás: sakkcsapat Európa-bajnokságok . . . . . . . . . . . 99

7.2.1. Választott példák és megvalósítás . . . . . . . . . . . . . . . . 99

7.2.2. A rangsorok ábrázolása . . . . . . . . . . . . . . . . . . . . 102

7.2.3. Egy rangsor elemzése . . . . . . . . . . . . . . . . . . . 107

7.2.4. A rangsorok összehasonlítása és értékelése . . . . . . . . . . . 110

7.3. Összegzés . . . . . . . . . . . . . . . . . . . 115 
8. A páros összehasonlítások további alkalmazásai

8.1. Ígéretes felhasználási területek . . . . . . . . . . . . . . . . . . . 118

8.2. Páros összehasonlítások egyéni értékelésekből . . . . . . . . . . . . . 120

8.3. Megoldási keret a felmerülö problémákhoz . . . . . . . . . . . . . . 122

8.4. Összegzés . . . . . . . . . . . . . . . . . . . 125

9. Összefoglalás $\quad 126$

Függelékek $\quad 131$

F.I. Függelék: A reguláris páros összehasonlítási multigráf esete . . . . . 132

F.II. Függelék: Lineáris rendezések távolsága . . . . . . . . . . . . . . . . 137

F.III. Függelék: Sakkcsapat EB-k eredményei és rangsorai . . . . . . . . . 143

F.IV. Függelék: Rangsorok összehasonlítói ábrái .......... 150

F.V. Függelék: Axiómák összefoglaló táblázatai . . . . . . . . . . . . . . 153

$\begin{array}{ll}\text { Idézetek } & 158\end{array}$

Az idézetek forrása . . . . . . . . . . . . . . . . . . . . . . 158

Az idézetek fordítása . . . . . . . . . . . . . . . . . . . . 159

$\begin{array}{ll}\text { Irodalomjegyzék } & 160\end{array}$

$\begin{array}{lr}\text { Saját publikációk } & 172\end{array}$

Idegen nyelvü . . . . . . . . . . . . . . . . . . . . . . . . . . 172

Magyar nyelvü . . . . . . . . . . . . . . . . . . . . . 173 


\section{Ábrák jegyzéke}

2.1. A 2.1. Példa rangsorolási problémája . . . . . . . . . . . . . . . . 11

3.1. A 3.1. Példa rangsorolási problémája . . . . . . . . . . . . . . 29

3.2. A 3.1. Példa $\mathbf{x}(\varepsilon)$ értékelövektorai . . . . . . . . . . . . . . . . . 30

4.1. A 3.1. Példa kiegyensúlyozott összehasonlítási multigráfja . . . . . . . 42

4.2. A 4.1. Példa q értékelővektorának közelítése . . . . . . . . . . . . . . 43

5.1. Az 5.1. Példa rangsorolási problémája . . . . . . . . . . . . . 54

5.2. Az 5.3. Példa rangsorolási problémái . . . . . . . . . . . . . 58

5.3. Az 5.5. Példa rangsorolási problémája . . . . . . . . . . . . 66

5.4. Az 5.6. Példa rangsorolási problémája . . . . . . . . . . . . . . 67

5.5. Az 5.7. Példa rangsorolási problémái . . . . . . . . . . . . . . . 69

5.6. Az 5.9. Példa rangsorolási problémái . . . . . . . . . . . . . 75

6.1. A 6.1. Példa rangsorolási problémái . . . . . . . . . . . . . . . . . . 81

6.2. A 6.3. Példa rangsorolási problémája . . . . . . . . . . . . 86

6.3. A 6.5. Példa rangsorolási problémája . . . . . . . . . . . . . . 89

6.4. A 6.5. Példa $\mathbf{x}(\varepsilon)$ értékelővektorai . . . . . . . . . . . . . . . 90

7.1. A 2013-as sakkcsapat EB eredményeinek eloszlása . . . . . . . . . . . 101

7.2. A 2011-es sakkcsapat EB skálatérképei . . . . . . . . . . . . . . 105

7.3. A 2013-as sakkcsapat EB skálatérképei . . . . . . . . . . . . . . . . 106

7.4. Teljes elörejelző képesség, 2011-es sakkcsapat EB . . . . . . . . . . 111

7.5. Mintailleszkedés, 2013-as sakkcsapat EB . . . . . . . . . . . . 113

7.6. Stabilitás a fordulók között, 2011-es sakkcsapat EB . . . . . . . . . . 114

9.1. Az 5. fejezetben tárgyalt axiómák kapcsolata . . . . . . . . . . . . . . 127

F.1. Az F.I.1. Példa rangsorolási problémája . . . . . . . . . . . . . . . . . 132

F.2. Az F.I.1. Példa q értékelővektorának közelítése . . . . . . . . . . . . . 133

F.3. Az F.I.2. Példa rangsorolási problémája . . . . . . . . . . . . . . . . . 134

F.4. Az F.I.2. Példa q értékelővektorának közelítése . . . . . . . . . . . . . 135

F.5. Következő forduló elörejelző képessége, 2013-as sakkcsapat EB .... 151

F.6. Stabilitás a fordulók között, 2013-as sakkcsapat EB . . . . . . . . . . 152 


\section{Táblázatok jegyzéke}

7.1. A 2011-es sakkcsapat Európa-bajnokság rangsorainak távolsága . . . 103

7.2. Pozícióváltozások az $L S\left(A^{M P}\right)$ rangsor közelítésében, 2013 . . . . . . 108

9.1. Pontozási eljárások axiomatikus összehasonlítása . . . . . . . . . . . . 128

F.1. A 2011-es sakkcsapat Európa-bajnokság eredményei . . . . . . . . . . 144

F.2. A 2013-as sakkcsapat Európa-bajnokság eredményei . . . . . . . . . . 146

F.3. A 2011-es sakkcsapat Európa-bajnokság rangsorai . . . . . . . . . . . 148

F.4. A 2013-as sakkcsapat Európa-bajnokság rangsorai . . . . . . . . . . . 149

F.5. Fogalmak és pontozási eljárások . . . . . . . . . . . . . . . . . 153

F.6. Pontozási eljárások az axiómák tükrében . . . . . . . . . . . . . . 155

F.7. Tulajdonságok kapcsolata . . . . . . . . . . . . . . . . . 157 
Il n'y a que deux puissances au monde, le sabre et l'esprit: à la longue, le sabre est toujours vaincu par l'esprit.

Bonaparte Napóleon 


\section{Köszönetnyilvánítás}

Egyesek azt állították, hogy kitünő matematikus volt ez az uralkodó; kétségkívül mély és éles gondolkodásról tett tanúságot; ám az, amit matematikai tudása melletti bizonyítékul szoktak felhozni, nem túlságosan meggyözö; meg akarta változtatni a tízes számrendszert, s helyette a hatvannégyes számot javasolta, mert e szám magában foglalja a köböt is, és a négyzetet is, mert továbbá mindvégig osztható kettővel, és így végeredményben visszavezethető az egységre. Ez a gondolata csupán azt bizonyítja, hogy mindenben a rendkíülit és a nehezet kereste.

Voltaire: XII. Károly

Ezúton szeretnék köszönetet témavezetőimnek, Fülöp Jánosnak és Temesi Józsefnek, akik széleskörü szakmai támogatásuk mellett sokat tettek e dolgozat és az ahhoz vezető publikációim megszületéséért és színvonalának növeléséért. Hálával tartozom az MTA SZTAKI Mérnöki és Üzleti Intelligencia Kutatólaboratórium Operációkutatás és Döntési Rendszerek Kutatócsoportjának a kutatás feltételeinek biztosításáért.

Az értekezés kidolgozásában nagy segítséget nyújtottak konferencia előadásaim felkért hozzászólói, Kóczy Á. László (MKE éves konferencia 2011, 2012), Kőrösi Gábor (MKE-PTE doktorandusz nyári mühely 2013), Pintér Miklós Péter (BCE Közgazdaságtani Doktori Iskola éves konferenciája, 2013), Csóka Péter (MKE éves konferencia 2013) és Komlósi Sándor (MKE-PTE doktorandusz nyári mühely 2014) építő jellegü javaslatai. Köszönöm az ezeken és más szakmai rendezvényeken született többi kiegészítést is.

Hasznos ötleteket és észrevételeket kaptam Bíró Pétertől, Burak Cantól, Pavel Chebotarevtól, Forgó Ferenctől, Julio González-Díaztól, Schepp Zoltántól és Tasnádi Attilától, a BCE Közgazdaságtudományi Kar Matematika, illetve Operációkutatás és Aktuáriustudományok Tanszékének számos munkatársától, korábbi tanáraimtól. Szemináriumi meghívásaimért köszönet illeti Csendes Tibort és Illés Tibort, a 2011. évi Magyar Operációkutatási Konferencián való részvételemért pedig a Gazdaságmodellezési Társaságot. Nem feledkezhetek meg a BCE Játékelméleti Szeminárium szervezőiről, Pintér Miklós Péterről és Solymosi Tamásról, akik az elmúlt években számos alkalommal biztosítottak lehetőséget kutatási eredményeim megvitatására. 
Társszerzőim, Bozóki Sándor, Rónyai Lajos, Tapolcai János és Temesi József szintén nagyban hozzájárultak kutatómunkám sikereihez.

A tudományos kutatás iránti érdeklődés felkeltéséért köszönettel tartozok szakdolgozataim konzulenseinek, Révész Tamásnak és Vincze Jánosnak, valamint Zalai Ernőnek.

A kutatómunka hátországára térve köszönettel tartozom a HM HIM Hadtörténelmi Délutánok rendezvénysorozat szervezőinek és előadóinak. Mindenképp meg kell említenem Dr. Számvéber Norbert őrnagy úr és Kiss László nevét, akik kiváló könyveikkel segítették a tudományos kutatómunkától sem elszakadó kikapcsolódásomat.

Szüleim és testvérem feltétlen támogatásukkal, bátorító tanácsaikkal biztosították zavartalan kutatómunkámat. Szeretnék köszönetet mondani barátaimnak, B. A.nak, Cs. D.-nek, F. N.-nek, J. Zs.-nek, R. A. R.-nek és T. E.-nek, akik pozitívan fogadták sokszor merész gondolataimat. Különösen hálás vagyok E. D.-nek végtelen segítőkészségéért, valamint N. Zs. A.-nak (Ninának) a közös elképzelésekért.

Végül, de korántsem utolsósorban, ismét meg kell említenem Bozóki Sándort, aki talán a legtöbbet tette a disszertáció létrejöttéért.

A dolgozatban maradt hibákért természetesen kizárólag én vagyok felelős.

$\mathrm{Az}$ értekezéshez vezető kutatás részben a TÁMOP 4.2.4.A/1-11-1-2012-0001 azonosító számú Nemzeti Kiválóság Program - Hazai hallgatói, illetve kutatói személyi támogatást biztosító rendszer kidolgozása és működtetése országos program című kiemelt projekt keretében zajlott. A projekt az Európai Unió támogatásával, az Európai Szociális Alap társfinanszírozásával valósul meg. A szerző köszönetet mond az OTKA K 77420 és K 111797 pályázatok pénzügyi támogatásáért, valamint az MTA „Lendület” programjának is. 


\section{1. fejezet}

\section{Bevezetés}

All science is either physics or stamp collecting.

Ernest Rutherford

Az utóbbi évek, évtizedek mindennapi életünket egyik leginkább befolyásoló folyamata az információs technológia rohamos fejlődése. A világról rendelkezésre álló adatmennyiség bővülése azonban messze meghaladja az emberi elme befogadóképességének növekedését, ezért elengedhetetlen a beérkező információ szűrése, az adott pillanatban számunkra releváns tényezők kiválasztása. Ez szinte reménytelen feladat a prioritások világos meghatározása, rangsorolása nélkül. A döntési alternatívák különböző jellemzői, eltérő tulajdonságai miatt azonban ezek nem feltétlenül mérhetők egyetlen, jól meghatározott skálán. Ugyanakkor az objektumok páronkénti összehasonlításának eredménye ekkor is biztosíthatja a sorrend felállítását.

Valószínüleg nem gondolnánk, egy átlagos napon milyen sokszor találkozunk a páros összehasonlítások alapján történő rangsorolással. Ez húzódik meg az internetes keresés, egy sportbajnokság eredményei, vagy az online piacokról ismerős „Ehhez a termékhez leggyakrabban az alábbiakat választják vásárlóink” jellegű ajánlások mögött. Ezért úgy véljük, nem haszontalan megismerkedni a hasonló feladatok matematikai hátterével, a megoldásra javasolt módszerek alkalmazási lehetőségeivel.

\subsection{Célok és kihívások}

A páros összehasonlításokkal történő rangsorolás három, részben összefüggő területen vet fel kérdéseket. Az első a vizsgált gyakorlati probléma matematikai reprezentációja, a második az így keletkező feladat megoldása, a harmadik a kapott eredmények értelmezése. Értekezésünk az előbbi kettőre fókuszál, bár a 7. fejezetben bemutatott alkalmazásban az utóbbira is kitérünk.

Az első kérdés irodalma viszonylag korlátozott. Egy-egy alkalmazás leírásakor természetesen elengedhetetlen az adatok modellbe ágyazásának tárgyalása, mégsem 
ismerünk olyan cikket, tanulmányt, amely átfogóan elemezné ennek végrehajtását. E területen Jiang et al. (2011) munkája érdemel említést, bár ez szinte kizárólag az egyéni értékelésekből levezetett páros összehasonlítások meghatározásával foglalkozik. Ezért egyik célunk az ismert alkalmazások minél szélesebb körének bemutatása (bár itt sem törekedhettünk a teljességre), illetve a gyakorlati felhasználók számára hasznos tanácsok megfogalmazása. Emellett bemutatunk egy, korábbi kutatásaink (Csató, 2012a,b, 2013a) továbbfejlesztésének tekinthető konkrét alkalmazást.

A másik témában már több cikk született. A feladat megoldásának vizsgálatakor az axiomatikus tárgyalást fogjuk követni, mely Lloyd S. Shapley 2012-es Nobeldíjával újfent bizonyította létjogosultságát a közgazdaságtanban. Az egy-egy módszer karakterizációját, illetve az általunk használtnál szűkebb értelmezési tartományt tárgyaló (például Laslier (1997) vagy Altman és Tennenholtz (2008)) munkákon kívül három fontosabbat említenénk. Chebotarev és Shamis (1998a) az ismert axiomatizációkat tekinti át, számos szempont szerint csoportosítja a több mint 40 módszerhez kapcsolódó tulajdonságokat. Chebotarev és Shamis (1999) a győzelem-vereség egyesítésén és kombinálásán alapuló eljárások megkülönböztetése révén fogalmaz meg erős állításokat, bár a cikk végén ígért ${ }^{1}$ teljes körü karakterizáció eddig nem történt meg. Erre González-Díaz et al. (2014) sem vállalkozik, ellenben számtalan ismert módszert elemez a 14 választott axióma tükrében.

A kérdés általunk adott tárgyalása leginkább González-Díaz et al. (2014) cikkéhez hasonlít. Ehhez több új tulajdonságot vezetünk be, azonban terjedelmi okokból bizonyos eredményeinket kénytelenek voltunk mellőzni (Csató, 2013b, 2014b). Vizsgálatunkat a pontszám, az általánosított sorösszeg és a legkisebb négyzetek módszerekre szükítjük, döntésünket igyekszünk kimerítően indokolni. A González-Díaz et al. (2014) által szintén elemzett fair bets eljárással Csató (2013d) és Csató (2014b) foglalkozik, míg a maximum likelihoodot - elsősorban a lineáris megoldhatóság hiánya miatt teljesen mellőzzük.

\subsection{Az értekezés szerkezete}

A 2. fejezet a páros összehasonlításokkal történő rangsorolás egy, a későbbi tárgyalás alapját képező általános modelljét mutatja be. Bevezetjük a rangsorolási probléma fogalmát (2.1. alfejezet), melyre alternatív definíciókat, egy minimálisat és egy jobban áttekinthetőt adunk. Utóbbi lehetővé teszi a páros összehasonlítások gráf reprezentációját (2.2. alfejezet), ami komoly segítséget nyújt bizonyos módszerek értelmezésében. A 2.3. alfejezetben az objektumok sorrendjének felállítására javasolt

${ }^{1}$ The analysis of indirect scoring procedures started in this paper is intended to be continued with additional axioms (two possible conditions were mentioned in this section), and with the end goal of axiomatic construction of such procedures (Chebotarev és Shamis, 1999, 223. o.). 
megközelítéseket tekintjük át, és a pontozási eljárások használata mellett érvelünk. Ezek irodalmát axiomatikus szempontból ismertetjük (2.4. alfejezet), kitérve a karakterizációkra és a tudománymetriai alkalmazhatóság kérdésére. A 2.5. részben adott összefoglalás során egy aggregálással kapcsolatos problémát is felvetünk.

A 3. fejezet a pontozási eljárásokat tárgyalja. Definiáljuk a későbbiekben használt módszereket (3.1. alfejezet), köztük a klasszikus pontszámot és az általánosított sorösszeget (Chebotarev, 1989, 1994). A 3.2. alfejezetben a legkisebb négyzetek módszerét tárgyaljuk, a 3.3. alfejezetben pedig az egyértelmű megoldhatósággal támasztjuk alá a választott pontozási eljárások jelentőségét. A 3.4. szakasz összegzése röviden foglalkozik az általánosított sorösszeg paraméterének megválasztásával is.

A 4. fejezet az általánosított sorösszeg és a legkisebb négyzetek módszerének egy gráf interpretációját adja. Először technikailag előkészítjük a fő eredmény kimondását (4.1. alfejezet), majd a 4.2. alfejezetben részletesen elemezzük a legkisebb négyzetek iteratív felbontását. Kitérünk az irodalomban javasolt hasonló eljárásokra, a kapott matematikai formula értelmezésére és a rendhagyó esetek vizsgálatára (F.I. Függelék). Bemutatjuk a gráf interpretáció egy lehetséges kiterjesztését, az általánosított Buchholz módszert, bizonyítjuk az általánosított sorösszeggel való ekvivalenciáját (a 4.3. alfejezet). Tárgyalásunkat a 4.4. részben - az eredmények áttekintése mellett néhány nyitott kérdés felvetésével zárjuk.

Az 5. fejezet pontozási eljárásokra vonatkozó axiómákat ismertet, melyek teljesülését a pontszám, az általánosított sorösszeg, és a legkisebb négyzetek módszere esetén vizsgáljuk. Az 5.1. alfejezet a rangsor változatlanságának legegyszerübb eseteit tárgyalja korábban bevezetett fogalmak révén. Ezután a rangsorolási problémák multiplikatív (5.2. alfejezet) és additív (5.3. alfejezet) transzformációit elemezzük. Mindkettőhöz bevezetünk egy-egy új tulajdonságot, az előbbinél pedig rámutatunk egy, a szakirodalomban eddig nem említett következményre is. Az 5.4. rész az eredménymátrix és az objektumok sorrendjének kapcsolatával foglalkozik. Átfogó képet nyújtunk két ismert tulajdonság viszonyáról, emellett kísérletet teszünk a rangsorolás különböző megközelítéseinek egyesítésére. Megmutatjuk az irreleváns összehasonlítások értelmezését, melyet összekapcsolunk a rangsorolási problémák additivitásával, és vizsgáljuk a döntetlenek hatását (5.5. alfejezet). Ezt a szakaszt szintén rövid áttekintéssel és a saját eredmények kiemelésével fejezzük be (5.6. alfejezet).

A 6. fejezet az általánosított sorösszeg és a legkisebb négyzetek módszere pontszámmal való kapcsolatát elemzi. Utóbbi Bouyssou (1992) által adott karakterizációjának kimondásához két új tulajdonság, az erős monotonitás és a kör függetlenség bevezetése szükséges. Belátjuk, hogy ez az eredmény csak a körmérkőzéses rangsorolási problémák meglehetősen szűk halmazán érvényes (6.1. szakasz), ahol az általunk vizsgált pontozási eljárások ekvivalensek a pontszám módszerrel (6.2. alfejezet). Ezt követően egy korábbról ismert és egy új axiómán keresztül elemezzük a sorösszeggel 
megmaradó összefüggéseket hiányos és többszörös összehasonlítások megengedése jelenlétében. Befejezésül áttekintjük a kapott eredményeket, és rámutatunk, hogy az általános esetben egyetlen pontozási eljárásnak sem létezik elfogadhatónak tűnő axiomatizációja (6.3. alfejezet).

A 7. fejezetben a választott pontozási eljárásokat svájci rendszerű sakk csapatversenyek eredményének meghatározására alkalmazzuk. A 7.1. szakasz ezek rangsorolási problémaként történő modellezését ismerteti: foglalkozunk a nem körmérkőzéses esetben felmerülő kérdésekkel, az egyéni és csapatversenyek jellemzőivel, a hivatalos lexikografikus rendezések hibáival. Igyekszünk megőrizni az axiomatikus szemlélet előnyeit, definícióinkat összekapcsoljuk az előző fejezetekben bevezetett tulajdonságokkal. A 7.2. alfejezet két sakkcsapat Európa-bajnokság részletes elemzését adja. A rangsorok összehasonlítására az F.II. Függelékben tárgyalt távolságfüggvényeket (Can, 2014) használjuk, majd a sokdimenziós skálázás segítségével ábrázoljuk azokat. Az eltérések okait a 4 . fejezetben bizonyított dekompozícióval tárjuk fel. A sorrendeket három szempont, az előrejelző képesség, a mintailleszkedés és a robusztusság alapján értékeljük, következtetéseinket a 7.3. alfejezetben fogalmazzuk meg.

A 8. fejezet a páros összehasonlítások gyakorlati alkalmazásaival foglalkozik. Ismertetjük ezek használatát a statisztika (EKS-módszer), a tudománymetria, a pszichológia, a szavazáselmélet és a sport területén (8.1. alfejezet), majd bevezetjük a termékértékelési feladatok szavazó-alternatíva mátrixát, és rangsorolási problémára való visszavezetésének módjait (8.2. szakasz). A 8.3. alfejezetben egy keretet adunk a páros összehasonlítások alapján történő rangsorolásra, ajánlásainkat példákkal illusztráljuk. Tárgyalásunkat összefoglalással zárjuk (8.4. alfejezet).

Az egyes szakaszok tartalmát azok végén összegezzük, így a 9. fejezetben csak röviden vázoljuk a főbb pontokat, további kutatási irányokat. Az axiomatikus megközelítés eredményeit a 9.1. ábrán és a 9.1. táblázatban mutatjuk be.

Az értekezés függelékeiben megvizsgáljuk a gráf reprezentáció egy speciális, Csató (2014a) által nem tárgyalt esetét (F.I. Függelék), Can (2014) nyomán indokoljuk a távolságfüggvények kiválasztását (F.II. Függelék), közöljük a 7. fejezetben elemzett sakk csapatversenyek részleteit (F.III. Függelék) és néhány további ábrát (F.IV. Függelék), valamint összefoglaljuk a dolgozatban szereplő definíciókat, a pontozási eljárásokra bevezetett axiómák kapcsolatát és az ezekre vonatkozó állítások származási helyét (F.V. Függelék).

A különböző részek meglehetősen szorosan kapcsolódnak egymáshoz. A 2-6. fejezetek lényegében egymásra építkeznek, a módszertani megalapozásához elengedhetetlen vizsgálatokat tárgyalnak. A 7. fejezet viszont, bár felhasználja a bevezetett rangsorolási eljárásokat és axiomatikus eredményeket, önmagában is értelmezhető (Csató, 2014c). A 8. fejezetben adott áttekintés lazábban kötődik a többihez, egy korábbi cikkünk részét képezi (Csató, 2013d). 


\subsection{Az értekezés eredményei}

A 2. fejezetben ugyan nem kerül megfogalmazásra komolyabb önálló eredmény, az eredmény- és mérkőzésmátrixok bevezetését mégis jelentősnek tartjuk a szakirodalom egységes keretben történő elhelyezése, a gráf reprezentáció felépítése, és az axiomatikus vizsgálat szempontjából. Ezenkívül a különböző területeken javasolt eljárások és karakterizációk ismertetése tekinthető újdonságnak.

A 3. fejezetben a mi hozzájárulásunk a legkisebb négyzetek és az $L L S M$ módszer ekvivalenciájának megmutatása, mely lehetővé teszi a páros összehasonlításokra ismert axiomatikus eredmények alkalmazását az AHP módszertanban. Szintén saját eredmény a megoldhatóságra vonatkozó feltételek tárgyalása.

A 4. fejezetben a legkisebb négyzetek módszere, majd ennek alapján az általánosított sorösszeg gráf interpretációjának megmutatása tünik a legfontosabbnak, de - különösen a pozíciós erő tekintetében - lényegesnek tartjuk az irodalomban ismert módszerekkel történő összevetést is. A levezetésekhez többnyire jól ismert matematikai állításokat használunk, ezek összegyüjtése és megfelelő keretbe rendezése azonban nem kis feladatot jelentett.

Az 5. és 6. fejezetben adott axiomatikus tárgyalás jelentősebb eredményei:

- Az általánosított sorösszeg változó, a mérkőzésszámtól megfelelő mértékben függő $\varepsilon$ paraméterrel történő alkalmazásának belátása a homogenitás és az eredmény konzisztencia tulajdonságok révén;

- A skála invariancia bevezetése, melynek megkövetelésével egyes pontozási eljárások esetén bővíthető az egyértelmű megoldásra vezető rangsorolási problémák halmaza;

- A konzisztencia megsértésének belátása az általánosított sorösszeg módszer esetén;

- Az eredmény konzisztencia definíciója és vizsgálata;

- A szimmetria és a megfordíthatóság kapcsolatának részletes elemzése;

- A pontozási eljárások és a rangsorolási probléma lineáris rendezéssel közelítése között kapcsolatot teremtő lineáris rendezés megőrzése axióma bevezetése és megsértésének bizonyítása (Rónyai Lajossal közösen);

- A függetlenség az irreleváns eredményektől tulajdonság definíciója, valamint az irreleváns mérkőzésektől (eredményektől) való függetlenség összekapcsolása a(z eredmény) konzisztenciával az általunk tárgyalt általános esetben; 
- A függetlenség a döntetlenektől axióma bevezetése és vizsgálata;

- Bouyssou (1992) pontszám módszerre adott karakterizációja érvénytelenségének belátása az értelmezési tartomány bővítése esetén;

- Az általános esetben adott axiomatizációk kritikai elemzése;

- Az ellenfelek homogén kezelése tulajdonság bevezetése és vizsgálata.

A 7. fejezet egésze saját hozzájárulás. Bár korábban is születtek javaslatok rekurzív alapú módszerek használatára svájci rendszerü sakkversenyeken (Brozos-Vázquez et al., 2010), ez tekinthető az első, axiomatikus megközelítésű gyakorlati vizsgálatnak. Lezárjuk a sakk csapatversenyek rangsorolási problémaként való modellezésének kérdését, és jelentős lépést teszünk a megfelelő pontozási eljárás kiválasztása felé. Az alkalmazást bemutató rész szintén tartalmaz innovatív elemeket: a súlyozott távolság számítása nagy valószínűséggel Can (2014) javaslatának első gyakorlati alkalmazása, és - egy korábbi cikkünktől (Csató, 2013a) eltekintve - a sokdimenziós skálázást sem használták hasonló rangsorok összehasonlítására. Emellett kiemelnénk a stabilitás bevezetését a svájci rendszerü versenyek rangsorolásának értékelésére.

A 8. fejezet, a korábbiakkal ellentétben, nem módszertani jellegü. Itt lényegesnek tartjuk az alkalmazási területek összegyüjtését, tudomásunk szerint eddig sehol sem jelent meg a páros összehasonlítások statisztikai felhasználása. A megfogalmazott ajánlások nagymértékben segíthetik a gyakorlati felhasználók munkáját. Ennek illusztrálására felhívjuk az olvasó figyelmét a Telcs et al. (2013a) cikkre, erre adott reakciónkra (Csató, 2013c), és a viszontválaszra (Telcs et al., 2013b).

A 4. és a 7 . fejezet teljes egészében önálló eredményeket tartalmaz, emellett jelentős saját hozzájárulás található az 5. és a 6. részben. Ezek publikálása részben már megtörtént (Csató, 2014a), részben - korábbi kutatásaink folytatásaként (Csató, 2012a,b, 2013a) - folyamatban van (Csató, 2014b,c).

\subsection{Jelölések}

Az értekezés csak minimális matematikai (elsősorban algebrai) előképzettséget igényel az olvasótól, csaknem minden szükséges fogalmat definiálni fogunk. A kétdimenziós mátrixokat és skalárokat formázás nélkül, a vektorokat és többdimenziós mátrixokat félkövér betúkkel szedjük. $\mathrm{x}$ mindig oszlopvektor, a megfelelő sorvektort

$\mathbf{x}^{T}$ jelöli. A természetes számok $\mathbb{N}$ halmaza alatt az összes nemnegatív egész számot értjük, míg $\mathbb{R}_{+}$a nemnegatív valós számok halmaza. 


\section{2. fejezet}

\section{A páros összehasonlításon alapuló rangsorolás modellje}

The essence of the rationality concept is that choice on large sets must depend 'in a positive way' on choices in two-element sets.

Az 1. fejezetben vázolt feladatok megoldásához szükséges azok átfogalmazása a matematika nyelvére. A következőkben bemutatjuk a páros összehasonlítások általunk használt modelljét, és az ezek alapján történő rangsorolásra javasolt különböző megközelítéseket, melyek közül a pontozási eljárások használata mellett érvelünk.

\subsection{A rangsorolási probléma}

2.1. Jelölés. $\mathbf{0} \in \mathbb{R}^{n}$ a nullvektor.

$\mathbf{e} \in \mathbb{R}^{n}$ a csupa 1-esből álló vektor.

$O \in \mathbb{R}^{n \times n}$ a nullmátrix.

$I \in \mathbb{R}^{n \times n}$ az egységmátrix, melynek fóátlójában 1-esek, azon kívül pedig 0-k vannak. $J \in \mathbb{R}^{n \times n}$ a csupa 1-esből álló mátrix.

Mint láttuk, a páronként összehasonlított alternatívák rangsorolásának problémája több területen is felmerül, ennek megfelelően a szerteágazó irodalomban a feladatot eltérő megközelítéssel, különböző modellkeretek mellett tárgyalták, ezért elsőként az általunk használt koncepciókat mutatjuk be (Csató, 2014a).

2.1. Definíció. Objektumhalmaz (set of objects): ${ }^{2} N=\left\{X_{1}, X_{2}, \ldots, X_{n}\right\}, n \in \mathbb{N}$ az objektumok halmaza.

${ }^{2}$ Bár az értekezés magyar nyelven készült, tervezem a fóbb eredmények nemzetközi publikálását, ezért a fogalmak mögött zárójelben szerepel a már használt (ez esetben hivatkozással) vagy az általam alkotott angol terminológia. Utóbbival kapcsolatban bármilyen észrevételt szívesen fogadok. 
2.2. Definíció. Egyéni páros összehasonlítási mátrix (individual paired comparison matrix): ${ }^{3} R^{(p)}=\left(r_{i j}^{(p)}\right) \in \mathbb{R}_{+}^{n \times n}$ a parciálisan definiált egyéni páros összehasonlítási mátrix, ahol

- $r_{i j}^{(p)}$ és $r_{j i}^{(p)}$ ismeretlen, vagy $r_{i j}^{(p)}+r_{j i}^{(p)}=1$ minden $i \neq j$-re;

- $r_{i i}^{(p)}=0$ minden $i=1,2, \ldots, n$-re.

$R^{(p)}$ a $p$-edik szavazó preferenciáit, a p-edik kísérlet, esetleg egy sportbajnokság $p$-edik fordulójának eredményét stb. adja meg. Amennyiben $r_{i j}^{(p)}$ ismert, annak esélyeként értelmezhető, hogy a $p$-edik körben $X_{i}$ jobbnak bizonyult $X_{j}$-nél. A diagonálisban szereplő elemeknek, az objektumok önmagukkal vett összehasonlításainak a későbbiekben nem lesz jelentősége.

2.3. Definíció. Preferenciaprofil (preference profile): $\mathrm{Az}(N, \mathbf{R})$ pár egy preferenciaprofil, ahol $N$ az objektumok halmaza, míg $\mathbf{R}=\left(R^{(1)}, R^{(2)}, \ldots, R^{(m)}\right), m$ darab $n \times n$-es mátrix összessége, amire $R^{(p)}$ egyéni páros összehasonlítás mátrix minden $p=1,2, \ldots, m$ esetén.

2.2. Jelölés. Az $n$ elemű objektumhalmazok felett értelmezett preferenciaprofilok halmaza $\mathcal{R}_{*}^{n}$.

2.3. Jelölés. $\chi_{(N, \mathbf{R})}:\{1 ; 2 ; \ldots ; m\} \times N \times N \rightarrow\{0 ; 1\}$ az $(N, \mathbf{R})$ preferenciaprofilban ismert elemek indikátorfüggvénye:

$$
\chi_{(N, \mathbf{R})}\left(p, X_{i}, X_{j}\right)= \begin{cases}1 & \text { ha } X_{i} \neq X_{j} \text { és } r_{i j}^{(p)} \text { ismert } \\ 0 & \text { különben. }\end{cases}
$$

A páros összehasonlítások eredményeit egy újabb mátrixban összegezhetjük.

2.4. Definíció. Aggregált páros összehasonlítási mátrix (aggregated paired comparison matrix): $R=\left(r_{i j}\right) \in \mathbb{R}_{+}^{n \times n}$ az $(N, \mathbf{R})$ preferenciaprofilhoz tartozó aggregált páros összehasonlítási mátrix, ahol

$$
r_{i j}= \begin{cases}0 & \text { ha } \sum_{p=1}^{m} \chi_{(N, \mathbf{R})}\left(p, X_{i}, X_{j}\right)=0 \\ \sum_{p=1, \chi_{(N, \mathbf{R})}\left(p, X_{i}, X_{j}\right)=1}^{m} r_{i j}^{(p)} & \text { különben. }{ }^{4}\end{cases}
$$

Természetesen lehetőség van az $r_{i j}^{(p)}$ eredmények súlyozott összeadására, a szavazók vagy a fordulók jelentőségének megkülönböztetésére is, ha ezt megfelelő (külső) információ indokolja. Például sporteredmények előrejelzésekor hasznosnak tűnik az időben közelebbi mérkőzések fontosabbnak ítélése (Bassett, 1997).

${ }^{3}$ A páros összehasonlítás mátrix elnevezést az AHP (Analytic Hierarchy Process) módszertanban használt pairwise comparison matrix kifejezésnek tartjuk fenn (Saaty, 1980).

${ }^{4} \mathrm{Az}$ összegzés csak az ismert elemekre történik. 
2.5. Definíció. Irreducibilitás (irreducibility): Az $R$ aggregált páros összehasonlítási mátrix irreducibilis, ha minden $X_{i} \neq X_{j}$-re létezik olyan $X_{i}=X_{k_{0}}, X_{k_{1}}, \ldots, X_{k_{t}}=X_{j}$ objektumsorozat, hogy $r_{k_{\ell} k_{\ell+1}}>0$ minden $\ell=0,1, \ldots, t-1$ esetén. $R$ reducibilis, ha nem irreducibilis.

A fogalom minden négyzetes mátrixra értelmezhető.

2.6. Definíció. Rangsorolási probléma (ranking problem): $(N, R)$ az $(N, \mathbf{R})$ preferenciaprofilhoz tartozó rangsorolási probléma, ahol $R$ a preferenciaprofil aggregált páros összehasonlítási mátrixa.

2.4. Jelölés. A rangsorolási problémák halmaza $\mathcal{R}$. Az $N$ halmazon értelmezett, vagyis $n$ objektumot tartalmazó rangsorolási problémák halmaza $\mathcal{R}^{n}$.

2.1. Megjegyzés. Több $(N, \mathbf{R})$ preferenciaprofilhoz is tartozhat ugyanaz a rangsorolási probléma.

A 2.6. Definícióban megadott modell az alábbi jelenségek leírására alkalmas:

1. Döntetlen $\left(r_{i j}=r_{j i}\right)$ : a döntéshozók összességében nem képesek különbséget tenni két objektum között;

2. Eltérő preferenciaintenzitás $\left(r_{i j} \geq 0\right.$ tetszőleges) : a páros összehasonlítások eredménye nem feltétlenül binárisan (jobb/rosszabb) adott, hanem például gyakorisági alapon, így $r_{i j} /\left(r_{i j}+r_{j i}\right)=0,8$ azt jelentheti, hogy az $X_{i}$ objektum az esetek 80\%-ában bizonyult jobbnak $X_{j}$-nél;

3. Hiányzó összehasonlítás $\left(r_{i j}=r_{j i}=0\right)$ : két objektum egymás elleni teljesítménye ismeretlen;

4. Többszörös összehasonlítás $\left(r_{i j}+r_{j i}>1\right)$ : egyes objektumpárok viszonya több alkalommal került meghatározásra (például két teniszező több mérkőzést játszott egymással), esetleg különbözik az összehasonlítások megbízhatósága.

A döntetlenek megjelenése a változó preferenciaintenzitás megengedésének egyenes következménye. A többszörös összehasonlítások a preferenciaprofil definíciójából adódnak. Noha ideális esetben ezek száma minden objektumpár esetén azonos, a szavazóknak lehetőségük van a választás elkerülésére is, ezért egyes összehasonlítások hiányozhatnak. Ennek oka sokszor az objektumok jelentős száma: amennyiben a páros összehasonlítások elvégzése költség-, idő- vagy egyéb korlátokba ütközik, nincs lehetőség minden viszony lekérdezésére. Bizonyos sportágakban ezért rendeznek egyenes kieséses (knockout) vagy svájci rendszerü (Swiss-system) versenyeket. Egy másik eset lehet az előrejelzés igénye, mielőtt egy körmérkőzéses (round-robin) bajnokság összes fordulóját lejátszották volna.

Ugyanakkor modellünk két lehetőséget nem képes megragadni: 
1. Nem szimmetrikus kimenetel: két objektum páros összehasonlításakor nem lehet eltekinteni ennek irányától;

2. Önmagával vett összehasonlítás.

A nem szimmetrikus eredmények beépítése meglehetősen nehéz és ritka, bár például a sportban komoly jelentősége lehet. Ennek ellenére a fenti keret (Chebotarev és Shamis, 1998a; González-Díaz et al., 2014) szinte az összes, szakirodalomban ismert páros összehasonlítás definíciót magában foglalja, talán az egyetlen kivétel a súlyozott irányított gráf esete, mely megengedi az egyes csúcsokhoz tartozó pozitív súlyú hurokéleket (Herings et al., 2005). A később bemutatott tudománymetriai problémákra ez nem feltétlenül igaz, ott az önhivatkozásoknak is lehet jelentősége.

A fenti esetek egy gráf segítségével szemléltethetők, melynek minden csúcsa egy-egy objektumnak, az élek pedig a köztük levő összehasonlításoknak felelnek meg. Amennyiben az előzőekben említett komplikációk egyike sem áll fenn, olyan teljes irányított gráfról beszélhetünk, ahol az élek irányítása a szigorú preferenciarelációt írja le. Döntetlenek esetén két csúcs között oda-vissza irányú élek keletkezhetnek. Különböző intenzitások mellett súlyozott irányított gráfot kapunk. Hiányzó párok esetén a gráf nem teljes. Többszörös összehasonlításoknál két csúcsot több (akár súlyozott) él is összeköthet. Nem szimmetrikus eredmények megjelenésekor a két csúcs közötti élek súlya eltérő lehet attól függően, melyik irányba mutatnak, míg az „önmagával” vett összehasonlítások hurokélekként reprezentálhatók.

Bizonyos esetekben, elsősorban a könnyebb értelmezés okán célszerü lehet a páros összehasonlítások számát és kimenetelét egyaránt magába foglaló $R$ aggregált páros összehasonlítási mátrix két részre bontása.

2.7. Definíció. Eredménymátrix (results matrix): $A=\left(a_{i j}\right) \in \mathbb{R}^{n \times n}$ az $(N, \mathbf{R})$ preferenciaprofilhoz tartozó eredménymátrix, ahol $a_{i j}=r_{i j}-r_{j i}$ minden $X_{i} \neq X_{j}$-re és $a_{i i}=0$ minden $X_{i} \in N$-re.

Az $A$ eredménymátrix ferdén szimmetrikus $\left(A^{\top}=-A\right)$, és azonos a Saaty-féle páros összehasonlítás mátrixszal (Saaty, 1980), ha az utóbbi elemenkénti logaritmusait vesszük (Csató, 2012b).

2.8. Definíció. Mérkőzésmátrix (matches matrix): $M=\left(m_{i j}\right) \in \mathbb{R}^{n \times n}$ az $(N, \mathbf{R})$ preferenciaprofilhoz tartozó mérkőzésmátrix, ahol $m_{i j}=r_{i j}+r_{j i}$ minden $X_{i}, X_{j} \in$ $\in N$-re.

Az $M$ mérkőzésmátrix szimmetrikus $\left(M^{\top}=M\right)$.

2.2. Megjegyzés. $a_{i j} \in\left[-m_{i j}, m_{i j}\right]$ minden $X_{i}, X_{j} \in N$-re. Speciálisan $m_{i j}=0$ esetén $a_{i j}=0$. Továbbá $m_{i j}=\sum_{p=1}^{m} \chi_{(N, \mathbf{R})}\left(p, X_{i}, X_{j}\right)$ minden $X_{i}, X_{j} \in N$-re, azaz $M \in \mathbb{N}^{n \times n}$, az összehasonlítások száma minden objektumpárra egész. 
2.9. Definíció. Rangsorolási probléma (ranking problem): $(N, A, M) \in \mathcal{R}^{n}$ az $(N, \mathbf{R})$ preferenciaprofilhoz tartozó rangsorolási probléma, ahol $A$ és $M$ a megfelelő $R$ aggregált páros összehasonlítási mátrixból adódó eredmény- és mérkőzésmátrixok.

Ha a rangsorolási probléma csak az $(N, A, M) \in \mathcal{R}^{n}$ formában adott, azaz nem ismerjük a hozzá tartozó $(N, \mathbf{R})$ preferenciaprofilt, akkor az egyszerüség érdekében feltesszük, hogy az $M$ mérkőzésmátrix elemei egész számok. Ugyan a későbbi eredmények mindegyike érvényes a folytonos esetben is, de helyenként sokkal bonyolultabb jelölések alkalmazása válna szükségessé. Az alkalmazások szempontjából ez nem igazi megszorítás. Miután $0 \leq m_{i j} \leq m$, feltehető $m=\max \left\{m_{i j}: X_{i}, X_{j} \in N\right\}$.

2.3. Megjegyzés. Az $(N, A, M) \in \mathcal{R}^{n}$ rangsorolási problémát gyakran irányított gráfokkal szemléltetjük, ahol a csúcsok az objektumok, a $k$ számú $\left(X_{i}, X_{j}\right) \in N \times N$ nem irányított él az $\left[a_{i j}\left(=a_{j i}\right)=0, m_{i j}=k\right]$, a $k$ számú $\left(X_{i}, X_{j}\right) \in N \times N$ irányított él pedig az $\left[a_{i j}=k\left(a_{j i}=-k\right), m_{i j}=k\right]$ páros összehasonlítást jelöli.

2.1. ábra. A 2.1. Példa rangsorolási problémája

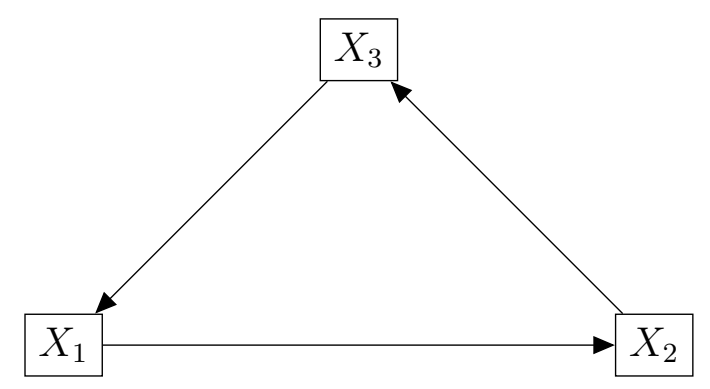

2.1. Példa. Tekintsük az $(N, A, M) \in \mathcal{R}^{3}$ rangsorolási problémát, ahol:

$$
A=\left[\begin{array}{ccc}
0 & 1 & -1 \\
-1 & 0 & 1 \\
1 & -1 & 0
\end{array}\right] \quad \text { és } \quad M=\left[\begin{array}{lll}
0 & 1 & 1 \\
1 & 0 & 1 \\
1 & 1 & 0
\end{array}\right]
$$

Ez a Condorcet-paradoxonnak (Condorcet, 1785) megfelelő példa a 2.1. ábrán látható.

2.10. Definíció. Speciális rangsorolási problémák: Egy $(N, A, M) \in \mathcal{R}^{n}$ rangsorolási probléma

- kiegyensúlyozott (balanced), ha $\sum_{X_{k} \in N} m_{i k}=\sum_{X_{k} \in N} m_{j k}$ minden $X_{i}, X_{j} \in$ $\in N$-re, azaz minden páros összehasonlítás ugyanannyiszor került végrehajtásra;

- körmérközéses (round-robin), ha $m_{i j}=m_{k \ell}$ minden $X_{i} \neq X_{j}$ és $X_{k} \neq X_{\ell}$ különböző objektumokból álló pár esetén;

- súlyozatlan (unweighted), ha $m_{i j} \in\{0 ; 1\}$ minden $X_{i}, X_{j} \in N$ esetén; 
- bajnokság (tournament), ha $m_{i j}=1$ és $a_{i j} \in\left\{-m_{i j} ; m_{i j}\right\}$ minden $X_{i} \neq X_{j}$-re.

Kiegyensúlyozottság esetén az ismert összehasonlítások egyenletesen helyezkednek el a rangsorolási problémában. A körmérkőzéses problémák abban az értelemben teljesnek tekinthetők, hogy $m=m_{i j}, X_{i} \neq X_{j}$ miatt egyetlen páros összehasonlítás sem ismeretlen. Súlyozatlan esetben nem megengedettek a többszörös összehasonlítások, az $A$ eredménymátrix szinte teljesen leírja a rangsorolási problémát, de $a_{i j}=0$ egyszerre felel meg a döntetlennek és a hiányzó összehasonlításnak. Bajnokságokban bármely két objektum összehasonlításra került, nincsenek döntetlenek vagy eltérő preferenciaintenzitások, azaz egy teljes, aszimmetrikus bináris reláció az $N$ halmazon. 2.5. Jelölés. A kiegyensúlyozott rangsorolási problémák halmaza $\mathcal{R}_{B}$.

A körmérkőzéses rangsorolási problémák halmaza $\mathcal{R}_{R}$.

A súlyozatlan rangsorolási problémák halmaza $\mathcal{R}_{U}$.

A bajnokságok halmaza $\mathcal{R}_{T}$.

2.4. Megjegyzés. $\mathcal{R}_{R} \subset \mathcal{R}_{B} \subset \mathcal{R}$ és $\mathcal{R}_{T} \subset\left(\mathcal{R}_{R} \cap \mathcal{R}_{U}\right) \subset \mathcal{R}_{B} \subset \mathcal{R}$.

2.11. Definíció. Speciális mérkőzésmátrixok (Brozos-Vázquez et al., 2008): Az M mérkőzésmátrix blokk diagonális (block diagonal), illetve blokk antidiagonális (block anti-diagonal), ha az $N$ halmaznak - az objektumok átindexelésének megengedésével - létezik olyan $N^{1} \cup N^{2}=N, N^{1} \cap N^{2}=\emptyset,\left|N_{1}\right|=n_{1} \geq 1$ és $\left|N_{2}\right|=n_{2}=n-n_{1} \geq 1$ partíciója, amire:

$$
M=\left(\begin{array}{cc}
M_{n_{1} \times n_{1}}^{1} & O_{n_{1} \times n_{2}} \\
O_{n_{2} \times n_{1}} & M_{n_{2} \times n_{2}}^{2}
\end{array}\right), \quad \text { illetve } \quad M=\left(\begin{array}{cc}
O_{n_{1} \times n_{1}} & M_{n_{1} \times n_{2}}^{1} \\
M_{n_{2} \times n_{1}}^{2} & O_{n_{2} \times n_{2}}
\end{array}\right)
$$

ahol az alsó indexek az almátrixok dimenzióit jelölik.

Ezek szintén értelmezhetők tetszőleges négyzetes mátrixra.

2.5. Megjegyzés. Az $R$ aggregált páros összehasonlítási mátrix akkor és csak akkor irreducibilis, ha nem blokk diagonális.

2.12. Definíció. Multihalmaz (multiset) (Chebotarev és Shamis, 1998a): A multihalmaz olyan halmaz, mely bizonyos elemeket többször is tartalmazhat.

A fogalmat Chebotarev és Shamis (1998a) egy pontozási eljárásokra vonatkozó axióma, az önkonzisztens monotonitás definiálása céljából vezette be.

2.6. Jelölés. $\uplus$ a halmazok olyan egyesítését (unióját) jelöli, mely megőrzi a többszörösen szereplő elemeket.

2.2. Példa. $O_{i}^{1}=\left\{X_{j}, X_{k}\right\}$ és $O_{i}^{2}=\left\{X_{k}, X_{\ell}\right\}$ esetén $O_{i}^{1} \uplus O_{i}^{2}=\left\{X_{i}, X_{k}, X_{k}, X_{\ell}\right\}$. 
2.13. Definíció. Ellenfél halmaz és multihalmaz: Legyen $(N, A, M) \in \mathcal{R}^{n}$ egy rangsorolási probléma. Ekkor

- az $X_{i} \in N$ objektum $p$-edik ellenfél halmaza (opponent set) a vele a $p$ edik körben összehasonlított objektumok halmaza: $O_{i}^{p}=\left\{X_{j}: m_{i j}=1\right\}$ minden $X_{i} \in N$-re és $p=1,2, \ldots, m$-re;

- az $X_{i} \in N$ objektum ellenfél multihalmaza (opponent multiset) a vele összehasonlított objektumok multihalmaza, mely pontosan annyiszor tar-

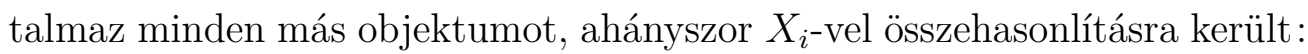
$O_{i}=\left\{X_{j}: \sharp X_{j}=m_{i j}\right\}$ minden $X_{i} \in N$-re.

Az $O_{i}$ ellenfél multihalmaz elemeit az $X_{i}$ objektum ellenfeleinek nevezzük.

2.6. Megjegyzés. $O_{i}=\uplus_{p=1}^{m} O_{i}^{p}$ minden $X_{i} \in N$-re.

2.7. Jelölés. $\left\{X_{j}\right\}^{m_{i j}} \subseteq O_{i}$ jelentése, hogy az $X_{j}$ objektum $m_{i j}$-szer szerepel $X_{i}$ ellenfél multihalmazában.

2.3. Példa. Legyen $N=\left\{X_{i}, X_{j}, X_{k}, X_{\ell}\right\}$ és $p=2$, valamint

$$
\chi_{(N, \mathbf{R})}\left(1, X_{i}, X_{j}\right)=\chi_{(N, \mathbf{R})}\left(1, X_{i}, X_{k}\right)=1 \text {, és } \chi_{(N, \mathbf{R})}\left(1, X_{i}, X_{\ell}\right)=0,
$$

illetve

$$
\chi_{(N, \mathbf{R})}\left(2, X_{i}, X_{j}\right)=0 \text {, és } \chi_{(N, \mathbf{R})}\left(2, X_{i}, X_{k}\right)=\chi_{(N, \mathbf{R})}\left(2, X_{i}, X_{\ell}\right)=1 \text {. }
$$

Ekkor $O_{i}^{1}=\left\{X_{j}, X_{k}\right\}$ és $O_{i}^{2}=\left\{X_{k}, X_{\ell}\right\}$, vagyis $O_{i}=O_{i}^{1} \uplus O_{i}^{2}=\left\{X_{i}, X_{k}, X_{k}, X_{\ell}\right\}$.

2.14. Definíció. Összehasonlítások száma: Legyen $(N, A, M) \in \mathcal{R}^{n}$ egy rangsorolási probléma. Ekkor

- az $X_{i} \in N$ objektum összehasonlításainak száma: $d_{i}=\sum_{X_{j} \in N} m_{i j}$;

- az összehasonlítások maximális száma: $\mathfrak{d}=\max \left\{d_{i}: X_{i} \in N\right\}$.

2.7. Megjegyzés. Egy rangsorolási probléma akkor és csak akkor kiegyensúlyozott, ha $\mathfrak{d}=d_{i}$ minden $X_{i} \in N$-re.

Súlyozatlan esetben $\mathfrak{d} \leq n-1$, körmérkőzéses rangsorolási problémákra $\mathfrak{d}=k(n-$ $-1), k \in \mathbb{N}$, bajnokságoknál pedig $\mathfrak{d}=n-1$, de ezen implikációk egyike sem igaz a fordított irányban. 


\subsection{A mérkőzésmátrix gráf reprezentációja}

Az $M$ mérkőzésmátrixot bizonyos esetekben gráfokkal reprezentáljuk, a következőkben ennek módját mutatjuk be.

2.15. Definíció. Gráfelméleti alapfogalmak: A $G=(N, E)$ pár egy gráf, ahol $N$ a csúcsok, E pedig az élek halmaza. Ekkor

- $G$ irányítatlan (undirected) gráf, ha $E \subseteq N \times N$ és $\left(X_{i}, X_{j}\right) \in E \Rightarrow$ $\left(X_{j}, X_{i}\right) \in E$ minden $X_{i}, X_{j} \in N$-re;

- G irányított (directed) gráf, ha $E \subseteq N \times N$ és $\left(X_{i}, X_{j}\right) \in E \nRightarrow\left(X_{j}, X_{i}\right) \in$ $\in E$

- $G$ egyszerü (simple) gráf, ha nem tartalmaz hurokélt, azaz $\left(X_{i}, X_{j}\right) \in$ $\in E \Rightarrow X_{i} \neq X_{j}$ minden $X_{i}, X_{j} \in N$-re;

- $G$ multigráf (multigraph), ha többszörös éleket is tartalmazhat, azaz $E \subseteq N \times N$ multihalmaz;

- G digráf (digraph), ha $G$ egyszerü, irányított gráf.

$G=(N, W)$ súlyozott (weighted) gráf, ha $W \in \mathbb{R}_{+}^{n \times n}$ egy nemnegatív mátrix, $w_{i j} \geq 0$ az $\left(X_{i}, X_{j}\right)$ él súlya.

A $G=(N, E)$ gráfban az $X_{i}=X_{k_{0}}, X_{k_{1}}, \ldots, X_{k_{t}}=X_{j}$ csúcssorozat egy $X_{i}$-ből $X_{j}$-be vezető út, ha $\left(X_{k_{\ell}}, X_{k_{\ell+1}}\right) \in E$ minden $\ell=0,1, \ldots, t-1$-re. Egy $X_{i}$-böl $X_{j}$-be vezető út kör, amennyiben $X_{i}=X_{j} . \mathrm{A} G=(N, E)$ irányítatlan gráf összefüggö, ha minden $X_{i}, X_{j} \in N$ esetén létezik $X_{i}$-ből $X_{j}$-be vezető út.

A $G=(N, E)$ irányítatlan gráfban az $X_{i} \in N$ csúcs fokszáma a vele szomszédos csúcsok száma: $\operatorname{deg}_{i}=\sharp\left\{X_{j}:\left(X_{i}, X_{j}\right) \in E\right\}$ minden $X_{i} \in N$-re. $D=\left(d_{i j}\right) \in \mathbb{R}^{n \times n}$ a fokszámokból képzett diagonális mátrix: $d_{i i}=\operatorname{deg}_{i}$ minden $X_{i} \in N$-re.

A $G=(N, E)$ multigráf

- páros (bipartite), ha léteznek olyan $\emptyset \neq U, V \subset N: U \cup V=N, U \cap V=\emptyset$ halmazok, hogy $\left(X_{i}, X_{j}\right) \in E \Rightarrow\left(X_{i}, X_{j}\right) \in U \times V$;

- reguláris (regular), ha $\operatorname{deg}_{i}=\operatorname{deg}_{j}$ minden $X_{i}, X_{j} \in N$-re;

- félreguláris páros (semiregular bipartite), ha páros, valamint $d e g_{i}=d e g_{j}$ minden $X_{i}, X_{j} \in U$-re és $\operatorname{deg}_{k}=\operatorname{deg}_{\ell}$ minden $X_{k}, X_{\ell} \in V$-re;

- reguláris páros (regular bipartite), ha reguláris és páros.

A $G=(N, E)$ multigráf szomszédsági mátrixa $T=\left(t_{i j}\right) \in \mathbb{R}^{n \times n}$, ahol $t_{i j}$ az $\left(X_{i}, X_{j}\right) \in E$ élek száma.

A $G=(N, E)$ multigráf Laplace-mátrixa $L=\left(\ell_{i j}\right) \in \mathbb{R}^{n \times n}$, ahol $L=D-T$. 
2.8. Megjegyzés. Egy páros multigráf nem tartalmaz páratlan hosszúságú kört.

2.1. Lemma. Egy $G=(N, E)$ multigráf Laplace-mátrixa szimmetrikus, $\mu_{1} \geq \mu_{2} \geq$ $\geq \ldots \geq \mu_{n}=0$ sajátértékei valósak, pozitív szemidefinit. $A \mu_{n}=0$-hoz tartozó sajátvektor $\mathbf{e}$.

Bizonyitás. Lásd Mohar (1991, Theorem 2.1).

2.16. Definíció. Összehasonlítási multigráf (comparison multigraph): Az irányítatlan $G:=(N, E)$ multigráf az $(N, A, M) \in \mathcal{R}^{n}$ rangsorolási problémához tartozó összehasonlítási multigráf, ahol az $N$ csúcshalmaz az objektumok halmaza és az $\left(X_{i}, X_{j}\right) \in E$ élek száma $m_{i j}$.

Egy $(N, A, M) \in \mathcal{R}^{n}$ rangsorolási problémához tartozó $G$ összehasonlítási multigráfban $\operatorname{deg}_{i}=d_{i}$, az $X_{i} \in N$ csúcs fokszáma a megfelelő objektum összehasonlításainak számával azonos.

2.9. Megjegyzés. A $G$ összehasonlítási multigráf csak az $M$ mérkőzésmátrixtól függ, Laplace-mátrixában $\ell_{i i}=d_{i}$ minden $X_{i} \in N$, és $\ell_{i j}=-m_{i j}$ minden $X_{i} \neq X_{j}$ esetén.

2.17. Definíció. Összefüggő rangsorolási probléma (connected ranking problem): $\operatorname{Egy}(N, A, M) \in \mathcal{R}^{n}$ rangsorolási probléma összefüggö, ha a hozzá tartozó $G=(N, E)$ összehasonlítási multigráf összefüggő.

2.8. Jelölés. Az összefüggő rangsorolási problémák halmaza $\mathcal{R}_{O}$.

Egy $(N, A, M) \in \mathcal{R}^{n}$ rangsorolási probléma akkor és csak akkor összefüggő, ha összehasonlítási multigráfjában minden $X_{i}, X_{j} \in N$-re található $X_{i}$-ből $X_{j}$-be vezető út.

2.2. Lemma. Legyen $(N, A, M) \in \mathcal{R}_{O}^{n}$ egy összefüggő rangsorolási probléma. Ekkor a következők ekvivalensek:

1. az $M$ mérközésmátrix blokk antidiagonális;

2. a G összehasonlítási multigráf páros.

Bizonyitás. Egy összefüggő (multi)gráf pontosan akkor páros, ha az $U$ és $V$ csúcshalmazokon belül nincs él.

\subsection{A rangsorolás különböző megközelítései}

A rangsorolási probléma definiálása után a következő feladatot az alternatívák sorba rendezése jelenti. Egyfajta információtömörítés válik szükségessé: az $n$ objektum $n(n-1) / 2$ kölcsönös „távolságát” kellene megfelelően leírni a megoldásként kapott 
rangsorból adódó $n-1$ különbséggel. Ez $n=2$ esetén tökéletesen reprodukálható, két objektum esetén a páros összehasonlítás kimenetele minden információt megad a sorrendről. Ha viszont azok száma legalább három, már felmerülhet a Condorcetparadoxonból (Condorcet, 1785) ismerős intranzitivitás problémája (2.1. Példa). Az ehhez hasonló inkonzisztenciák nem feltétlenül adathibából adódnak, konzisztens preferenciák aggregálása szintén ilyen következményekkel járhat.

Ez a nehézség már a körmérkőzéses rangsorolási problémák $\mathcal{R}_{R}$ osztályán is jelentkezik. Az általános esetben újabb bonyodalmak merülnek fel (David, 1987):

1. Az objektumok ellenfelei, az $O_{i}$ ellenfél multihalmazok elemei különböző erősségüek lehetnek, ami befolyásolja az általuk mutatott teljesítményt;

2. Az objektumok összehasonlításainak száma eltérhet egymástól, $d_{i} \neq d_{j}$.

David (1987) szerint az objektumok megfelelő rangsorolása nem várható el, ha azok összehasonlításainak száma jelentősen különbözik. Bizonyos esetekben a páros összehasonlítások olyan mértékű inkonzisztenciát tartalmazhatnak, ami értelmetlenné teszi egy rangsor felállítását. Ezzel a kérdéssel nem foglalkozunk, de felhívjuk a figyelmet Jiang et al. (2011) tanulmányára.

Moulin (1986) tanácsát követve célszerü elkülönítve vizsgálni a győztes megadásának, illetve egy teljes rangsor felállításának kérdését - mi csak az utóbbit fogjuk vizsgálni. Bár Bouyssou (2004) kísérletet tett a két megközelítés egyesítésére a legjobb alternatíva kiválasztásának sorozatos alkalmazása révén, eredményei arra utalnak, hogy az így definiált eljárások szinte biztosan megsértenek valamilyen monotonitási tulajdonságot, ezért a probléma megoldására inkább a közvetlen rangsoroló eljárások ajánlottak.

2.9. Jelölés. $X_{i} \succeq{ }_{(N, A, M)} X_{j}$ jelentése, hogy az $(N, A, M) \in \mathcal{R}^{n}$ rangsorolási problémában $X_{i}$ legalább olyan jó, mint $X_{j}$. Ez egyben meghatározza az alábbi relációkat:

- $X_{i} \succ_{(N, A, M)} X_{j}, X_{i}$ jobb $X_{j}$-nél, ha $X_{i} \succeq_{(N, A, M)} X_{j}$ és $X_{j} \nsucceq_{(N, A, M)} X_{i}$;

- $X_{i} \sim{ }_{(N, A, M)} X_{j}$, azaz $X_{i}$ és $X_{j}$ azonos erösségü, ha $X_{i} \succeq{ }_{(N, A, M)} X_{j}$ és $X_{j} \succeq{ }_{(N, A, M)} X_{i}$

- $X_{i} \perp_{(N, A, M)} X_{j}$, azaz $X_{i}$ és $X_{j}$ nem összehasonlítható, ha $X_{i} \nsucceq_{(N, A, M)} X_{j}$ és $X_{j} \nsucceq_{(N, A, M)} X_{i}$.

2.18. Definíció. Rangsor (ranking): Az $N$ objektumhalmazon értelmezett reflexív és tranzitív (de nem feltétlenül teljes) $\succeq_{(N, A, M)}$ bináris reláció rangsor.

2.10. Jelölés. Az $n$ objektumot tartalmazó rangsorok halmaza $\mathcal{P}^{n}$.

2.19. Definíció. Lineáris rendezés (linear order): Az $N$ objektumhalmazon értelmezett irreflexív, tranzitív, és teljes $\succ{ }_{(N, A, M)}$ bináris reláció lineáris rendezés. 
2.11. Jelölés. Az $n$ objektumot tartalmazó lineáris rendezések halmaza $\mathcal{L}^{n}$.

2.10. Megjegyzés. Minden lineáris rendezés tekinthető rangsornak, fordítva azonban nem feltétlenül, tehát $\mathcal{L}^{n} \subset \mathcal{P}^{n}$.

2.20. Definíció. Rangsorolási módszer (ranking method) : Egy $\mathcal{R}_{*}^{n} \rightarrow \mathcal{P}^{n}$ függvény rangsorolási módszer.

A rangsor meghatározásának egy lehetséges módja az alábbi.

2.21. Definíció. Általános pontozási eljárás (general scoring procedure): Egy $f$ : $\mathcal{R}_{*}^{n} \rightarrow \mathbb{R}^{n}$ függvény általános pontozási eljárás.

2.11. Megjegyzés. Minden $f: \mathcal{R}_{*}^{n} \rightarrow \mathbb{R}^{n}$ általános pontozási eljárás meghatároz egy $\succeq^{f}: \mathcal{R}^{n} \rightarrow \mathcal{P}^{n}$ rangsorolási módszert az $f_{i}(N, A, M) \geq f_{j}(N, A, M) \Rightarrow X_{i} \succeq$ $\succeq_{(N, A, M)}^{f} X_{j}$ definícióval. A kapott rangsor egyértelmü és teljes, $X_{i} \perp_{(N, A, M)}^{f} X_{j}$ nem lehetséges.

A továbbiakban csak olyan az általános pontozási eljárásokkal foglalkozunk, melyek az $R$ aggregált páros összehasonlítási mátrixon alapulnak. Chebotarev és Shamis (1999) bizonyítja, hogy egyetlen egyéni páros összehasonlítás mátrixon alapuló pontozási eljárás sem teljesítheti az önkonzisztens monotonitás (Chebotarev és Shamis, 1997) tulajdonságot. Utóbbi részletes bemutatását lásd Csató (2013b).

2.22. Definíció. Pontozási eljárás (scoring procedure): Egy $f: \mathcal{R}^{n} \rightarrow \mathbb{R}^{n}$ függvény pontozási eljárás.

2.23. Definíció. Arányosság (proportionality): Az $f^{1}, f^{2}: \mathcal{R}^{n} \rightarrow \mathbb{R}^{n}$ pontozási eljárások arányosak, ha létezik olyan $\kappa>0$ konstans, hogy $f^{1}(N, A, M)=\kappa f^{2}(N, A, M)$ minden $(N, A, M) \in \mathcal{R}^{n}$-re.

2.12. Jelölés. Az $f^{1}, f^{2}: \mathcal{R}^{n} \rightarrow \mathbb{R}^{n}$ pontozási eljárások arányosságának jele $f^{1} \propto f^{2}$.

2.3. Lemma. Arányos pontozási eljárások által generált rangsorok azonosak.

Ennél gyengébb összefüggés az alábbi.

2.24. Definíció. Ekvivalencia (equivalence) : Az $f^{1}, f^{2}: \mathcal{R}^{n} \rightarrow \mathbb{R}^{n}$ pontozási eljárások ekvivalensek, ha $f_{i}^{1}(N, A, M) \geq f_{j}^{1}(N, A, M) \Leftrightarrow f_{i}^{2}(N, A, M) \geq f_{j}^{2}(N, A, M)$ minden $X_{i}, X_{j} \in N$ objektumra és $(N, A, M) \in \mathcal{R}^{n}$ rangsorolási problémára.

2.13. Jelölés. Az $f^{1}, f^{2}: \mathcal{R}^{n} \rightarrow \mathbb{R}^{n}$ pontozási eljárások ekvivalenciájának jele $f^{1} \approx f^{2}$.

2.4. Lemma. Két arányos pontozási eljárás ekvivalens, az ekvivalenciából viszont nem következik az arányosság. 
A pontozási eljárásokon kívül a sorrend meghatározásának másik megközelítése a rangsorolás diszkrét optimalizálási problémaként való felfogása, egy $\mathcal{R}_{*}^{n} \rightarrow \mathcal{L}^{n}$ függvény közvetlen meghatározása.

2.25. Definíció. Optimális lineáris rendezés (optimal linear order) (Kemeny, 1959; Slater, 1961): A

$$
\min _{L \in \mathcal{L}^{n}} \sum_{X_{i}, X_{j} \in N}\left(r_{i j}: X_{i} \prec X_{j}\right)=\min _{L \in \mathcal{L}^{n}} \sum_{X_{i}, X_{j} \in N}\left(0,5 a_{i j}+0,5 m_{i j}: X_{i} \prec X_{j}\right)
$$

feladat $L \in \mathcal{L}^{n}$ megoldása egy, az $(N, A, M) \in \mathcal{R}^{n}$ rangsorolási problémához tartozó optimális lineáris rendezés.

A lineáris rendezés elvben kicserélhető egy $\mathcal{P}^{n}$-beli rangsorra, ekkor azonban nem világos, hogyan kell módosítani a célfüggvényt.

A feladat gyakran matematikai szempontból szép és mély kombinatorikus kérdésekhez, illetve bonyolult algoritmikus problémákhoz vezet (Hudry, 2009), de több, egymással összefüggő szempontból is kifogásolható:

1. Bizonyos esetekben, például azonos arányú körbeverések mellett a Condorcetparadoxonban, nem érdemes az érintett objektumok közül bármelyiket előrébb rangsorolni, indokolatlan a szigorú rendezés erőltetése;

2. Hiányzó páros összehasonlítások esetén még a lineáris rendezés rangsorral történő felváltása sem biztosítja egyes tulajdonságok, például az önkonzisztens monotonitás teljesülését (Chebotarev és Shamis, 1997);

3. A diszkrét optimalizálási módszerek normatív tulajdonságainak vizsgálata meglehetősen nehéz (Bouyssou, 2004);

4. A kapott sorrend gyakran nem egyértelmü, akár nagyméretű, sok objektumot tartalmazó esetekben is létezhetnek többszörös optimumok (Pasteur, 2010);

5. Általában kevésbé bünteti a gyengébb objektumok elleni rossz teljesítményt, mint a hasonlókkal szembenit, mert az előbbi biztosan növelni fogja a célfüggvényt, ami ellentétes a természetes elvárásainkkal (Pasteur, 2010).

Az első három elsősorban elméleti, az utolsó kettő viszont gyakorlati szempontból teszi kevéssé kívánatossá a megközelítés alkalmazását. Több optimális megoldás létezésekor különösen nehézzé válhat a kapott eredmény értelmezése.

A fenti problémák ellenére kétségtelenül vonzó egy valamilyen szempontból optimális megoldás megadása. A bináris, csak győzelmeket és vereségeket megengedő esetben például kézenfekvő választás - ahogy ez a 2.25. Definícióból adódik - azon összehasonlítások számának minimalizálása, ahol a rangsorban hátrébb található 
alternatíva jobbnak bizonyult egy nála előkelőbb helyen szereplőnél (Ali et al., 1986). Az ebből adódó bináris lineáris programozási feladat megoldása viszont nagyméretű problémák esetén meglehetősen bonyolult lehet. Egy ilyen, nem körmérkőzéses rangsorolási problémákra alkalmazható algoritmust tárgyal Coleman (2005).

A módszer iránt mélyebben érdeklődő olvasó figyelmébe ajánljuk Charon és Hudry (2007), illetve Charon és Hudry (2010) összefoglalóját.

\subsection{A pontozási eljárások axiomatikus szempontú áttekintése}

A pontozási eljárások talán legtömörebb jellemzése a következő: Scoring procedures transform profiles of individual preferences over a set of alternatives into scores of the alternatives. The scores can be used in themselves or serve as the basis for ranking or choice (Chebotarev és Shamis, 1998a, 299. o.). A leegyszerüsítés természetesen nem ,ingyenebéd”, az információtömörítés veszteségekkel járhat. Ez (is) indokolja a pontozási eljárások részletes elemzését.

Az ezirányú kutatások egyelőre kezdeti szakaszban vannak, semmiképpen sem tekinthetők lezártnak. Legígéretesebbnek egyfajta axiomatikus megközelítés alkalmazása tűnik: néhány kívánatos vagy elvárt tulajdonság definiálásával jól látható válnak azok ellentmondásai, kölcsönös kapcsolatai, és az egyes módszerek eltérései. Ez hasonlít a kooperatív játékelmélet elosztási koncepciói esetén követett megközelítéshez. A 2012-ben közgazdasági Nobel-díjat nyert Lloyd S. Shapley nevéhez füződő Shapley-értékre (Shapley, 1952) már számos axiomatizáció született, nem is említve a különböző játékosztályokon megfigyelhető eltéréseket (Pintér, 2009).

Több tanulmányban találkozunk egy-egy kiválasztott pontozási eljárás karakterizációjával, ezek azonban általában valamilyen szükebb halmazon, az itt vizsgáltnál kevésbé általános páros összehasonlítási mátrixok esetén érvényesek. Az első, közvetlenül adódó megoldási lehetőség a sorösszegek alapján történő rangsorolás, a pontszám módszer (Borda, 1781; Copeland, 1951). Ezt Rubinstein (1980) karakterizálta bajnokságokban $\left(\mathcal{R}_{T}\right)$, míg a szavazási modellekkel foglalkozó irodalomban legalább három különböző axiomatizáció létezik az $\mathcal{R}_{R}$ körmérkőzéses esetre (Young, 1974; Hansson és Sahlquist, 1976; Nitzan és Rubinstein, 1981; Bouyssou, 1992). Az itt tárgyalt általános esetben azonban egyik sem érvényes, ráadásul hiányzó és többszörös összehasonlítások mellett a módszer alkalmazása erősen vitatható (González-Díaz et al., 2014). A hiányzó összehasonlítások döntetlenként kezelésével ez a nehézség elvileg feloldható (Telcs et al., 2013a), ezzel azonban eltérünk az eredeti rangsorolási problémától, így attól különböző megoldást kaphatunk.

Számos módszer alapul a Perron-Frobenius tételen (egy nemnegatív, valós, négy- 
zetes és irreduciblis mátrix domináns sajátértékéhez tartozik az egyetlen szigorúan pozitív sajátvektor). Érdekesség, hogy az első ilyen, a sajátvektor iteratív számításához kapcsolódó javaslat már az állítás megjelenése előtt megszületett (Landau, 1895). Landau (1914) mintegy 20 évvel később, a tétel publikálása után újra visszatért a problémára. Ugyanezt az ötletet hasznosította Wei (1952) és Kendall (1955). Az $R$ aggregált páros összehasonlítási mátrix bizonyos transzformáltjainak domináns sajátvektorát használja az invariáns és a fair bets (Daniels, 1969; Moon és Pullman, 1970), vagy az előbbi egy perturbált változatának megfelelő PageRank módszer (Brin és Page, 1998). Ezeket az eljárásokat, Slutzki és Volij (2005), illetve Slutzki és Volij (2006) karakterizációit részletesen ismertette Csató (2013d), bár az invariáns módszer gráfelméleti, ordinális tulajdonságokon alapuló axiomatizációjára (Altman és Tennenholtz, 2005) nem tért ki.

A játékelméleti irodalomban hasonló feladatként merül fel egy irányított gráf csúcsainak rangsorolása. Ebben a környezetben könnyen érthető a lokális és globális pontozási eljárások megkülönböztetése: előbbiek az irányított gráf helyi struktúráját vizsgálják (a csúcsok értékelésénél csak azok közvetlen kapcsolatait, a bemenő és kimenő élek számát veszik figyelembe), utóbbiak viszont az egész gráfot tekintik (Herings et al., 2005). Ez egyúttal egy jól ismert axióma, az irreleváns összehasonlításoktól való függetlenség megjelenését indukálja (Rubinstein, 1980; González-Díaz et al., 2014), amit pontosan a lokális módszerek elégítenek ki. Rubinstein (1980) eredményének általánosítására van den Brink és Gilles (2003) tanulmánya tett kísérletet. A megoldási javaslatok közül érdemes még megemlíteni az invariáns és fair bets módszerekkel szoros kapcsolatban álló $\lambda$ eljárást (Borm et al., 2002; Slikker et al., 2012), és a pozíciós erőt (positional power) (Herings et al., 2005). Korábban már mindkettőt bemutattuk (Csató, 2013d), utóbbit részben itt is tárgyaljuk.

A különböző pontozási eljárásokra definiálása mellett viszonylag kevés az egyszerre több módszert axiomatikus megközelítéssel vizsgáló munka. Laslier (1997) számos megoldási koncepciót - a lehetséges karakterizációkra is kitérve - részletesen elemez, ugyanakkor vizsgálatát körmérkőzéses bajnokságokra korlátozza, ezért értekezésünk szempontjából kevésbé releváns. Chebotarev és Shamis (1998a) cikke kiváló áttekintést nyújt az ismert axiomatizációkról, több szempont szerint csoportosítja az ezekhez szükséges tulajdonságokat (összesen több mint 40 módszert tárgyal). Altman és Tennenholtz (2008) belátja, hogy irányított gráfokra nem létezik olyan pontozási eljárás, amely egyszerre rendelkezne jó lokális és globális tulajdonságokkal.

Chebotarev és Shamis (1999) az önkonzisztens monotonitás (Chebotarev és Shamis, 1997) szempontjából vizsgálja a pontozási eljárások két osztályát, bizonyítva, hogy minden győzelem-vereség kombináló (win-loss combining) eljárás megsérti azt. Ebbe a csoportba tartozik az invariáns és fair bets eljárás, illetve a játékelméleti irodalomban használt módszerek szinte mindegyike, köztük a $\lambda$ módszer és a pozíciós 
erő. Az önkonzisztens monotonitás kérdését részletesen tárgyalja Csató (2013b), érintőlegesen Csató (2013d) is foglalkozik vele.

Ugyanakkor létezik néhány olyan, győzelem-vereség egyesíto (win-loss unifying) eljárás, ami teljesíti az önkonzisztens monotonitást (Chebotarev és Shamis, 1999). Közülük kiemelkedik az egyik klasszikus módszer, a maximum likelihood (Zermelo, 1929; Bradley és Terry, 1952). Az eljárás széles körben ismert és elterjedt, azóta is születnek ezzel kapcsolatos eredmények: Conner és Grant (2000) a módszer kiterjesztésére tesz kísérletet, míg Conner és Grant (2009) egy új monotonitási tulajdonságról mutatja meg, hogy az általánosított eljárás teljesíti azt.

Az axiomatikus megközelítés a pontozási eljárások által meghatározott rangsorolási módszerek összehasonlítására is alkalmazható. González-Díaz et al. (2014) eredményei szerint kiemelkedően teljesít a maximum likelihood, amely azonban egy bonyolult nemlineáris egyenletrendszer megoldását kívánja, ezért számítási szempontból nem tekinthető tökéletes választásnak. Egy másik, elméleti szempontból vonzó eljárás az általánosított sorösszeg (generalized row sum) módszer (Chebotarev, 1989, 1994). Ez pontozási eljárások olyan parametrikus családja, melynek egyik határértéke a sorösszeg, másik pedig a legkisebb négyzetek (least squares) módszere (Horst, 1932; Mosteller, 1951; Morrissey, 1955; Gulliksen, 1956; Kaiser és Serlin, 1978). Kiszámítása egy lineáris egyenletrendszer megoldásával történik, ennek köszönhető gráfelméleti interpretációja is (Shamis, 1994).

Bár a legkisebb négyzetek módszere szintén megsérti az önkonzisztens monotonitás axiómáját (Chebotarev és Shamis, 1999; Csató, 2013d), egyszerüsége okán mégis széles körben használják. Belátható, hogy az eljárás ekvivalens a nem teljesen kitöltött páros összehasonlítás mátrixok esetén alkalmazott $L L S M$ módszerrel (Bozóki et al., 2010; Csató, 2012b), illetve a statisztikában használt EKS-eljárással; utóbbiról az alkalmazásokról szóló fejezetben olvashatunk. A párhuzamosan folyó kutatások eddig nem ismerték fel ezt az azonosságot, a megoldás egyértelmüségének legalább két bizonyítása létezik (Kaiser és Serlin, 1978; Bozóki et al., 2010).

Az egymástól független eredmények létezése azonban ezen a területen egyáltalán nem tekinthető rendkívülinek. Az invariáns módszer legalább három különböző alkalommal került bevezetésre (Daniels, 1969; Moon és Pullman, 1970; Pinski és Narin, 1976), a maximum likelihood esetén ugyancsak két alapművet szokás említeni (Zermelo, 1929; Bradley és Terry, 1952). Kóczy és Nichifor (2013) sem említi, hogy az invariáns módszer hibáinak korrigálására javasolt eljárásuk azonos a korábbról ismert fair bets módszerrel, így a szerzők valószínüsíthetően más úton jutottak erre a következtetésre. Hasonló esetek a játékelméletben sem ismeretlenek: a stabil házasság probléma megoldására szolgáló Gale-Shapley algoritmust (Gale és Shapley, 1962) gyakorlati felhasználók már a módszer publikálása előtt felfedezték.

Az utóbbi időben - González-Díaz et al. (2014) úttörő tanulmányától eltekintve - 
a legkisebb négyzetek módszere viszonylag kevés figyelmet kapott, holott az általánosított sorösszeg módszerrel való szoros kapcsolata azt sugallja, kedvező normatív tulajdonságokkal bírhat. Közeli rokonságban van a játékelméleti pozíciós erő fogalmával is, és a számítás menete, a PageRank módszerhez hasonlóan, szemléletesen értelmezhető gráfokon (Csató, 2014a). Ezek az érvek indokolják, hogy az axiomatikus megközelítés keretén belül a vele közeli kapcsolatban álló pontszám és általánosított sorösszeg mellett részletesen foglalkozunk a legkisebb négyzetek módszerével is.

Témánk részben érintkezik a tudománymetriában használt eljárások irodalmával, hiszen folyóiratok, cikkek vagy szerzők egymásra való hivatkozásai szintén leírhatók páros összehasonlításokkal. Azonban létezik egy alapvető különbség a két terület között: modellünkben az $X_{i}$ objektum $X_{j}$-vel szembeni jobb teljesítménye biztosan kedvezőtlen $X_{j}$ számára, míg az $X_{i}$-re való hivatkozás nem szükségképpen káros $X_{j}$-nek (Slutzki és Volij, 2006; González-Díaz et al., 2014). Ugyanakkor Kóczy és Strobel (2010), illetve Kóczy és Nichifor (2013) szerint az előbbi feltevés alkalmas lehet bizonyos manipulációs lehetőségek kizárására. Axiomatikus szemléletű tárgyalásunkban szintén említést érdemelnek Palacios-Huerta és Volij (2004), valamint Slutzki és Volij (2006) karakterizációs eredményei. Tudománymetriai problémákkal részben magunk is foglalkoztunk (Csató, 2013d).

\section{5. Összegzés}

A 2.1. szakaszban Chebotarev és Shamis (1998a), illetve González-Díaz et al. (2014) nyomán bemutattuk a páros összehasonlításon alapuló rangsorolás egyik legáltalánosabb modelljét, mely a nem szimmetrikus és az objektumok önmagukkal vett összehasonlításain kívül minden elképzelhető lehetőséget tartalmaz. Az eredményés mérkőzésmátrixok definiálásával rámutattunk a páros összehasonlítás mátrixokat használó AHP módszertannal (Saaty, 1980) való szoros kapcsolatra. Végül áttekintettük a fóbb fogalmakat és a rangsorolási problémák speciális eseteit.

A 2.2. alfejezet megmutatta a rangsorolási probléma összehasonlításainak szerkezetét tükröző $M$ mérkőzésmátrix gráf reprezentációját, amire azért volt szükségünk, mert több pontozási eljárásban szerepet játszik az összehasonlítási multigráf Laplace-mátrixa. A 2.3. részben a rangsorolás végrehajtásával foglalkoztunk. Megkülönböztettük a közvetlen megközelítést jelentő diszkrét optimalizálási feladatként való felfogást, a győztes sorozatos kiválasztásán alapuló módszereket, és a közvetett pontozási eljárások alkalmazását, majd felsorakoztattuk az utóbbiak használata mellett szóló érveinket.

A 2.3. alfejezet alapján a továbbiakban szinte kizárólag olyan pontozási eljárásokat tárgyalunk, melyek értelmezési tartománya - a 2.22. Definíciónak megfelelően - az $\mathcal{R}$ halmaz. Chebotarev és Shamis (1999) bizonyítja, hogy az $R^{(p)}$ egyéni páros össze- 
hasonlítás mátrixokon alapuló általános pontozási eljárások egyike sem teljesítheti az önkonzisztens monotonitás tulajdonságot.

A 2.4. alfejezetben axiomatikus szempontból mutattuk be a pontozási eljárások irodalmát. Röviden ismertettük a leggyakrabban használt módszereket, és kitértünk az ismert karakterizációkra. Számunkra különösen fontosnak bizonyult Chebotarev és Shamis (1998a) összefoglalója és González-Díaz et al. (2014) normatív alapú összehasonlítása. Előbbi a felsorolt eljárások és karakterizációk gazdagsága miatt, utóbbi pedig azért, mert a következőkben mi is egy hasonló szempontú vizsgálatot mutatunk be, lényegesen több axiómával, de kevesebb eljárásra fókuszálva. Említést tettünk a tudománymetriai tárgyalásokkal való kapcsolatról, bár a két terület eredményei nem feltétlenül feleltethetők meg egymásnak (Slutzki és Volij, 2006; González-Díaz et al., 2014).

A fejezetben a viszonylag korlátozott saját hozzájárulás ellenére fontosnak tartjuk az eredmény- és mérkőzésmátrixok bevezetését, mert ez teszi lehetővé a szakirodalom egységes keretben történő elhelyezését, a gráf reprezentáció felépítését. Ezenkívül a különböző területeken javasolt eljárások és karakterizációk ismertetése tekinthető újdonságnak.

Összefoglalónkat egy nyitott probléma felvetésével zárjuk. A páros összehasonlítások eredményének $R=\sum_{p=1}^{m} R^{(p)}$ aggregációja számos, az összehasonlításokkal kapcsolatos információt elfed, például $m=2$ esetén $r_{i j}=1$ egyaránt előállhat 1 és 0 , vagy 0,5 és 0,5 összegeként. Ennek ellenére nem ismerünk olyan pontozási eljárást, ami az aggregált $r_{i j}$ várható értéken kívül figyelembe venné az ezt eredményező $r_{i j}^{(p)}$ kimenetelek eloszlását, azt a tényt, hogy $r_{i j}^{(p)}$ általában nem azonos az $r_{i j} / m_{i j}$ átlaggal. Az $r_{i j}^{(p)}-r_{i j} / m_{i j}$ különbségek azonban jelentéssel bírhatnak $X_{i}$ és $X_{j}$ összehasonlítása szempontjából: a két objektum relatív viszonya sokkal stabilabbnak, megbízhatóbbnak tünik, ha $r_{i j}^{(p)} \approx r_{i j} / m_{i j}$ minden olyan $p=1,2, \ldots, m$-re, ahol $r_{i j}^{(p)}$ ismert. Egy lehetséges megoldás ennek beépítésére az $m_{i j}$ mérkőzésszám alkalmas transzformációja, növelése közel azonos $r_{i j}^{(p)}$ értékek esetén. 


\section{3. fejezet}

\section{Pontozási eljárások}

Kleine Opfer müssen gebracht werden.

Otto von Lilienthal

A 2. fejezetben megállapítottuk, hogy a páros összehasonlítások alapján történő rangsorolás elvégzésére a pontozási eljárások (2.22. Definíció) használata ajánlott.

\subsection{Néhány pontozási eljárás}

Az alábbiakban különböző rangsoroló eljárásokat mutatunk be.

3.1. Definíció. Név módszer (fixed-order method) (Slutzki és Volij, 2005): fo : $\mathcal{R}^{n} \rightarrow \mathbb{R}^{n}$, ahol $f o_{i}(N, A, M)=i$ minden $X_{i} \in N$-re és $(N, A, M) \in \mathcal{R}^{n}$-re.

A név módszer független az eredménymátrixtól, az értékelést az objektumok elnevezése határozza meg.

3.2. Definíció. Egyenlő módszer (flat method) (Slutzki és Volij, 2005): fl : $\mathcal{R}^{n} \rightarrow \mathbb{R}^{n}$, ahol $f l_{i}(N, A, M)=0$ minden $X_{i} \in N$-re és $(N, A, M) \in \mathcal{R}^{n}$-re.

Az egyenlő módszer szintén független az eredménymátrixtól, minden objektumnak azonos értékelést ad. A név módszerrel együtt inkább technikai célokat szolgál, gyakorlati alkalmazásuk nem ajánlott, ugyanakkor segíthetik a később tárgyalt tulajdonságok megértését.

3.3. Definíció. Pontszám módszer (score method) (Borda, 1781; Copeland, 1951): $\mathbf{s}: \mathcal{R}^{n} \rightarrow \mathbb{R}^{n}$, ahol $\mathbf{s}(N, A, M)=A \mathbf{e}$ minden $(N, A, M) \in \mathcal{R}^{n}$-re.

A pontszám módszert számítása miatt sorösszegnek (row sum) is nevezik. Ez az eljárás már figyelembe veszi az $A$ eredménymátrixot, bizonyos értelemben alkalmas a 2.3. alfejezet elején felvetett probléma, a Condorcet-paradoxon kezelésére: azonos mértékü körbeverések esetén az érintett objektumok között holtversenyt ad. 
Hiányzó és többszörös összehasonlítások (nem körmérkőzéses rangsorolási problémák) esetén azonban felmerül egy másik nehézség, amit a pontszám nem képes figyelembe venni: az objektumok megfigyelt teljesítményét, az $a_{i j}$ eredményeket az $O_{i}$ ellenfél multihalmaz is befolyásolja (González-Díaz et al., 2014). Például, amennyiben $X_{i}$ csupán $X_{j}$-vel került összehasonlításra egyetlen alkalommal, nem mindegy, vajon ez a végső rangsor szerint legjobb vagy legrosszabb objektum. Így szükségessé válhat az ellenfelek, majd az érvelést tovább folytatva, az ellenfelek ellenfeleinek stb. erejének vizsgálata (David, 1987). A következő módszer erre is alkalmasnak bizonyul.

Chebotarev (1989) néhány, a pontozási eljárásban szereplő függvénytől megkövetelt tulajdonság segítségével egy parametrikus eljáráscsaládot vezetett be, amit a szerző egy későbbi munkájában részletesen elemzett (Chebotarev, 1994).

3.4. Definíció. Általánosított sorösszeg módszer (generalised row sum method, $G R S$ ) (Chebotarev, 1989): $\mathbf{x}(\varepsilon): \mathcal{R}^{n} \rightarrow \mathbb{R}^{n}$, ahol $\varepsilon>0$ egy paraméter és $(I+$ $+\varepsilon L) \mathbf{x}(\varepsilon)(N, A, M)=(1+\varepsilon m n) \mathbf{s}$ minden $(N, A, M) \in \mathcal{R}^{n}$-re.

Az általánosított sorösszeg módszer az összehasonlítási multigráf szerkezetének segítségével figyelembe veszi az ellenfelek teljesítményét is, hiszen minden $X_{i} \in$ $\in N$-re $\left(1+\varepsilon d_{i}\right) q_{i}-\varepsilon \sum_{X_{j} \in N} m_{i j} q_{j}=(1+\varepsilon m n) s_{i}$. Az $\varepsilon$ paraméter a pontszám kiigazításának mértékét tükrözi, értékének megválasztásához azonban kevés támpont ismert. Az általánosított sorösszeg a Laplace-mátrix szerepeltetése miatt minden elérhető objektum értékelését figyelembe veszi. Egy alternatív megoldás lenne csak a közvetlen ellenfelek erejének beépítése, mint David (1987) módszerénél.

3.1. Lemma. Az általánositott sorösszeg arányos a pontszám módszerrel, $h a \varepsilon \rightarrow 0$, sót, $\lim _{\varepsilon \rightarrow 0} \mathbf{x}(\varepsilon)=\mathbf{s}$.

3.1. Megjegyzés. A 3.1. Lemma alapján a pontszám és az általánosított sorösszeg módszerrel kapcsolatos bizonyítások egyszerre kezelhetők $\varepsilon \geq 0$ megengedésével.

Ezt a lehetőséget - akár külön említés nélkül - többször is használni fogjuk.

Modellünkben a páros összehasonlítások eredménye korlátos, $-m \leq a_{i j} \leq m$ minden $X_{i}, X_{j} \in N$-re. Ekkor többet is mondhatunk az $\varepsilon$ paraméterről.

3.5. Definíció. $\varepsilon$ észszerü választása (reasonable choice of $\varepsilon$ ) (Chebotarev, 1994, Proposition 5.1) : Legyen $(N, A, M) \in \mathcal{R}^{n}$ egy rangsorolási probléma. Az általánosított sorösszeg módszer $\varepsilon$ paraméterének értéke észszerü, ha

$$
0<\varepsilon \leq \frac{1}{m(n-2)}
$$

$\mathrm{Az} \varepsilon$ paraméter észszerü felső határa $\bar{\varepsilon}=1 /[m(n-2)]$.

Az észszerü felső határ kiszámításához szükséges az $n \geq 3$ implicit feltevés, $n=2$ esetén a rangsorolási probléma megoldása amúgy is triviális. 
3.1. Állítás. Az $\varepsilon$ paraméter észszerü választása esetén $-m(n-1) \leq x_{i}(\varepsilon) \leq m(n-1)$ minden $X_{i} \in N$-re.

Bizonyítás. Lásd Chebotarev (1994, Property 13).

Ez az eredmény azért kívánatos, mert egy $(N, A, M) \in \mathcal{R}_{R}^{n}$ körmérkőzéses rangsorolási problémában $-m(n-1) \leq s_{i} \leq m(n-1)$ minden $X_{i} \in N$-re. Belátható, hogy az általánosított sorösszeg teljesíti az önkonzisztens monotonitás axiómát (Chebotarev és Shamis, 1997; Csató, 2013b), ha $\varepsilon$ értéke észszerü (Chebotarev és Shamis, 1999).

3.2. Állítás. A pontszám és az általánosított sorösszeg módszereknek tetszőleges $(N, A, M) \in \mathcal{R}^{n}$ rangsorolási probléma mellett egyértelmü megoldása létezik.

Bizonyítás. Lásd Chebotarev (1994, Property 1). A 2.1. Lemma szerint a Laplacemátrix pozitív szemidefinit, így $I+\varepsilon L$ tetszőleges $\varepsilon$ esetén invertálható.

3.2. Megjegyzés. A játékelméleti irodalomban (Borm et al., 2002; Slikker et al., 2012; Herings et al., 2005) egy $G=(N, E)$ digráf $\left(X_{i}, X_{j}\right) \in E$ irányított éle az $X_{i}$ csúcs $X_{j}$-vel szembeni dominanciáját jelenti.

3.1. Jelölés. Az $n$ csúcsból álló digráfok halmaza $\mathcal{D}^{n}$.

Ekkor a $G=(N, E) \in \mathcal{D}^{n}$ digráf egy $(N, A, M) \in \mathcal{R}^{n}$ rangsorolási problémaként reprezentálható, ahol az $A$ mérkőzésmátrix elemeire $a_{i j} \in\{-1 ; 0 ; 1\}$, míg az $M$ mérkőzésmátrixban $m_{i j} \in\{0 ; 1\}$. Továbbá

- $\left[\left(X_{i}, X_{j}\right) \in E\right.$ és $\left.\left(X_{j}, X_{i}\right) \notin E\right] \Leftrightarrow a_{i j}=1$ és $m_{i j}=1$;

- $\left[\left(X_{i}, X_{j}\right) \in E\right.$ és $\left.\left(X_{j}, X_{i}\right) \in E\right] \Leftrightarrow a_{i j}=0$ és $m_{i j}=1$;

- $\left[\left(X_{i}, X_{j}\right) \notin E\right.$ és $\left.\left(X_{j}, X_{i}\right) \notin E\right] \Leftrightarrow a_{i j}=0$ és $m_{i j}=0$.

Ezzel minden digráfokra definiált pontozási eljárás a modellünkben is értelmezhető. A megfeleltetés ugyanakkor nem egyértelmü, például felvethető, hogy a két csúcs között mindkét irányítással létező él két összehasonlítást jelent a megfelelő objektumok között.

3.6. Definíció. Pozíciós erö módszer (positional power method) (Herings et al., $2005): \mathbf{p}: \mathcal{D}^{n} \rightarrow \mathbb{R}^{n}$, ahol minden $G=(N, E) \in \mathcal{D}^{n}$ digráf esetén $\mathbf{p}=\lim _{k \rightarrow \infty} \mathbf{p}^{k}$ és

$$
\begin{gathered}
\mathbf{p}^{0}=\mathbf{0} \\
\mathbf{p}^{k}=T \mathbf{e}+\frac{1}{n} T \mathbf{p}^{k-1}, \quad k=1,2, \ldots
\end{gathered}
$$


Emlékeztetőül, $T$ a digráf szomszédsági mátrixa. Az iteráció első lépése, Te a digráf csúcsainak értékelését utódaik számaként adja meg. Ezt, azok korábbi erejének $1 / n$-szerese mellett, minden későbbi lépésben is megkapják.

Herings et al. (2005) említést tesz a pozíciós erő súlyozott irányított gráfokra történő kiterjesztéséről (ahol megengedett hurokélek, az objektumok önmagukkal vett összehasonlítása), de nem ad részletes elemzést arról.

\subsection{A legkisebb négyzetek módszeréröl}

A 2.3. alfejezet alapján a rangsorolás statisztikai feladatként értelmezhető: az $X_{i}$ és $X_{j}$ objektumok $h_{i j}$ teljesítménykülönbségét kell végső értékeléseik $f_{i}(N, A, M)$ - $f_{j}(N, A, M)$ eltérésével becsülni. Ideális esetben egyértelmüen létezik olyan $\mathbf{r} \in \mathbb{R}^{n}$ vektor, amire $h_{i j}-\left(r_{i}-r_{j}\right)=0 .{ }^{5}$ Ekkor $\left(r_{i}-r_{j}\right)+\left(r_{j}-r_{k}\right)+\left(r_{k}-r_{i}\right)=0$ következtében $h_{i j}+h_{j k}+h_{k i}=0$ minden $X_{i}, X_{j}, X_{k} \in N$ objektumhármasra. A páros összehasonlítások eredményeiből $n^{2}-n$ egyenlet adódik, az értékelővektorban viszont csak $n$ változó van, így az $f_{i}(N, A, M)-f_{j}(N, A, M)$ becsült várható érték eltérhet a $h_{i j}$ megfigyelt kimeneteltől, valamilyen közelítés alkalmazása szükséges. Kézenfekvő a legkisebb négyzetek módszerének alkalmazása:

$$
\min _{\mathbf{r} \in \mathbb{R}^{n}} \sum_{X_{i}, X_{j} \in N} m_{i j}\left(h_{i j}-r_{i}+r_{j}\right)^{2}
$$

Ezt a megközelítést Horst (1932) és Mosteller (1951) javasolta körmérkőzéses problémákra, Morrissey (1955) és Gulliksen (1956) terjesztette ki az általános esetre, Kaiser és Serlin (1978) pedig az egyértelmü megoldhatóság kérdésével foglalkozott. A feladat úgy is tekinthető, hogy az összegzést nem az objektumok, hanem az összehasonlítások halmazán végezzük az $i, j, p$ változókkal ( $p$ értelmezéséhez lásd a 2.2. Definíciót), ekkor a célfüggvényben nem szerepel súlyozás (Chebotarev és Shamis, 1999). $h_{i j}$ pontos alakja a modell szabadságfoka, gyakori választás a $h_{i j}=$ $=a_{i j} / m_{i j}$ (González-Díaz et al., 2014). A továbbiakban mi is ezt a specifikációt használjuk.

A körmérkőzéses esetben az $A$ eredménymátrix azonos a multiplikatív páros összehasonlítás mátrixszal (Saaty, 1980), amennyiben az utóbbi elemenkénti logaritmusait vesszük, míg a legkisebb négyzetek módszere ekvivalens az LLSM (logarithmic least squares) eljárással (Crawford és Williams, 1980; De Graan, 1980; Crawford és Williams, 1985). Nem teljesen kitöltött páros összehasonlítás mátrixok (Harker, 1987) esetén ugyanez érvényes az LLSM módszer Kwiesielewicz (1996) és Bozóki et al. (2010) által javasolt kiterjesztésével (Csató, 2012b).

${ }^{5}$ A multiplikatív páros összehasonlítás mátrixok irodalmában ezt konzisztenciának hívják, mi azonban a pontozási eljárások egyik tulajdonságára fogjuk használni az elnevezést. 
Az optimalitás elsőrendü feltételei az $r_{i} \in \mathbb{R}, i=1,2, \ldots, n$ korlátozás nélküli változókkal egy $n$ tagból álló lineáris egyenletrendszert adnak:

$$
\left(\begin{array}{cccccc}
d_{1} & -m_{12} & -m_{13} & \ldots & -m_{1, n-1} & -m_{1, n} \\
-m_{21} & d_{2} & -m_{23} & \ldots & -m_{2, n-1} & -m_{2, n} \\
-m_{31} & -m_{32} & d_{3} & \ldots & -m_{3, n-1} & -m_{3, n} \\
\vdots & \vdots & \vdots & \ddots & \vdots & \vdots \\
-m_{n-1,1} & -m_{n-1,2} & -m_{n-1,3} & \ldots & d_{n-1} & -m_{n-1, n} \\
-m_{n, 1} & -m_{n, 2} & -m_{n, 3} & \ldots & -m_{n, n-1} & d_{n}
\end{array}\right)\left(\begin{array}{c}
r_{1} \\
r_{2} \\
r_{3} \\
\vdots \\
r_{n-1} \\
r_{n}
\end{array}\right)=\left(\begin{array}{c}
s_{1} \\
s_{2} \\
s_{3} \\
\vdots \\
s_{n-1} \\
s_{n}
\end{array}\right)
$$

ahol a diagonálisban található $d_{i}=\sum_{X_{j} \in N} m_{i j}$ az $X_{i}$ objektum összehasonlításainak száma, az $(i, j)$ pozícióban szereplő elem pedig $-m_{i j}$, az $X_{i}$ és $X_{j}$ közötti összehasonlítások számának ellentettje, amikor $i \neq j$. A jobb oldalon $s_{i}=\sum_{X_{j} \in N} a_{i j}$ az $X_{i}$ objektum pontszáma. A bal oldalon szereplő $n \times n$-es mátrix tehát a 2.9. Megjegyzés értelmében a rangsorolási problémához tartozó $G$ összehasonlítási multigráf Laplace-mátrixa. A célfüggvény konvexitása miatt ez elegendő is a minimalitáshoz.

A fenti feladatnak végtelen sok megoldása van, mert a célfüggvény értéke minden $\mathbf{r}$ és $\mathbf{r}+\beta \mathbf{e}, \beta \in \mathbb{R}$ esetén azonos, ez azonban a rangsort nem befolyásolja. Az értékelések megszokott normalizálása $\mathbf{e}^{\top} \mathbf{r}=0$.

3.7. Definíció. Legkisebb négyzetek módszere (least squares method, $L S$ ) : q : $\mathcal{R}^{n} \rightarrow$ $\mathbb{R}^{n}$, ahol $L \mathbf{q}=\mathbf{s}$ és $\mathbf{e}^{\top} \mathbf{q}=0$ minden $(N, A, M) \in \mathcal{R}^{n}$-re.

Ebből $d_{i} q_{i}-\sum_{X_{j} \in N} m_{i j} q_{j}=s_{i}$ minden $X_{i} \in N$-re. A legkisebb négyzetek módszere szoros kapcsolatban áll az általánosított sorösszeg eljárással.

3.3. Állítás. Az általánosított sorösszeg arányos a legkisebb négyzetek módszerével, $h a \varepsilon \rightarrow \infty$, mégpedig $\lim _{\varepsilon \rightarrow \infty} \mathbf{x}(\varepsilon)=$ mnq.

Bizonyítás. Az arányosságot lásd Chebotarev és Shamis (1998a, 326. o.). $\varepsilon \rightarrow \infty$ határátmenetben az általánosított sorösszeg $(I+\varepsilon L) \mathbf{x}(\varepsilon)(N, A, M)=(1+\varepsilon m n) \mathbf{s}$ egyenletrendszerének konstans együtthatójú tagjai elhanyagolhatóvá válnak, ezért $\lim _{\varepsilon \rightarrow \infty} L \mathbf{x}(\varepsilon)=m n \mathbf{s}=m n L \mathbf{q}$.

Eszerint az általánosított sorösszeg és a legkisebb négyzetek módszere egyaránt tekinthető a pontszám egyfajta kiigazításának az összehasonlítási multigráf szerkezetének segítségével, annak Laplace-mátrixán keresztül, ahol az $\varepsilon$ paraméter a korrekció mértékét tükrözi. Az általánosított sorösszeg módszer a legkisebb négyzetes becslés bayesi változataként értelmezhető (Chebotarev, 1994).

3.3. Megjegyzés. A pontszám, az általánosított sorösszeg, és a legkisebb négyzetek módszere egy lineáris egyenletrendszer megoldását igényli, gyorsan és hatékonyan számítható (Jiang et al., 2011). 
3.1. ábra. A 3.1. Példa rangsorolási problémája

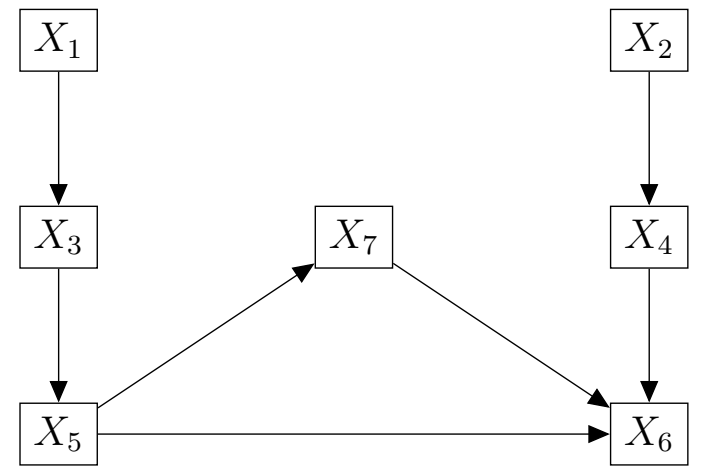

A 3.3. Megjegyzés miatt algoritmikus kérdésekkel nem foglalkozunk.

3.1. Példa. (Chebotarev, 1994, Example 1) Tekintsük az $(N, A, M) \in \mathcal{R}_{U}^{7}$ súlyozatlan rangsorolási problémát (3.1. ábra), ahol:

$$
A=\left[\begin{array}{ccccccc}
0 & 0 & 1 & 0 & 0 & 0 & 0 \\
0 & 0 & 0 & 1 & 0 & 0 & 0 \\
-1 & 0 & 0 & 0 & 1 & 0 & 0 \\
0 & -1 & 0 & 0 & 0 & 1 & 0 \\
0 & 0 & -1 & 0 & 0 & 1 & 1 \\
0 & 0 & 0 & -1 & -1 & 0 & -1 \\
0 & 0 & 0 & 0 & -1 & 1 & 0
\end{array}\right] \quad \text { és } \quad M=\left[\begin{array}{ccccccc}
0 & 0 & 1 & 0 & 0 & 0 & 0 \\
0 & 0 & 0 & 1 & 0 & 0 & 0 \\
1 & 0 & 0 & 0 & 1 & 0 & 0 \\
0 & 1 & 0 & 0 & 0 & 1 & 0 \\
0 & 0 & 1 & 0 & 0 & 1 & 1 \\
0 & 0 & 0 & 1 & 1 & 0 & 1 \\
0 & 0 & 0 & 0 & 1 & 1 & 0
\end{array}\right]
$$

Az általánosított sorösszeg módszerrel az $\varepsilon$ paraméter különböző értékei mellett kapott értékelések a 3.2. ábrán láthatók. Itt $m=1$ és $n=7$, ezért $\varepsilon=1 / 5$ az észszerü felső határ (a 3.2. ábrán függőleges vonallal jelölve). A pontszám módszer értékelővektora $\mathbf{s}(N, A, M)=[1,1,0,0,1,-3,0]^{\top}$. Ez nem tükrözi az ellenfelek erejét, azt feltételezi, hogy $X_{1}$ és $X_{5}$ azonos teljesítményt nyújtott, noha az előbbi $X_{3}$-on keresztül „dominálja” az utóbbit.

Tetszőleges $0<\varepsilon \leq 1 / 5$ mellett a rangsor $X_{1} \succ X_{2} \succ X_{5} \succ X_{3} \succ X_{4} \succ X_{7} \succ X_{6}$. A paraméter további növelésével azonban $X_{3}$ elöször $X_{5}$-öt, majd $X_{2}$-t előzi meg. Ezen sorrendek mindegyike mellett szólhatnak érvek, mert az $X_{2}$ és $X_{3}$ objektumok csak legalább három másikon keresztül hasonlíthatók össze, melynek kimenetele nem egyértelmü, míg $X_{3}$ és $X_{5}$ viszonya a különböző fokszámok miatt eldönthetetlen. $\varepsilon$ emelkedése - a saját pontszám fokozatosan csökkenő szerepe mellett - egyre nagyobb súlyt ad az indirekt kapcsolatoknak.

Ugyanakkor a legkisebb négyzetek módszere némileg kifogásolható értékeléseket ad $\left(\mathbf{q}(N, A, M)=[38 / 3,10 / 3,17 / 3,-11 / 3,-4 / 3,-32 / 3,-18 / 3]^{\top}\right)$, mert azok között 10-nél nagyobb és -10-nél kisebb is található, miközben egy hét objektumból álló súlyozatlan, körmérkőzéses (teljes) rangsorolási probléma esetén azok maximuma 
3.2. ábra. A 3.1. Példa $\mathbf{x}(\varepsilon)$ értékelővektorai

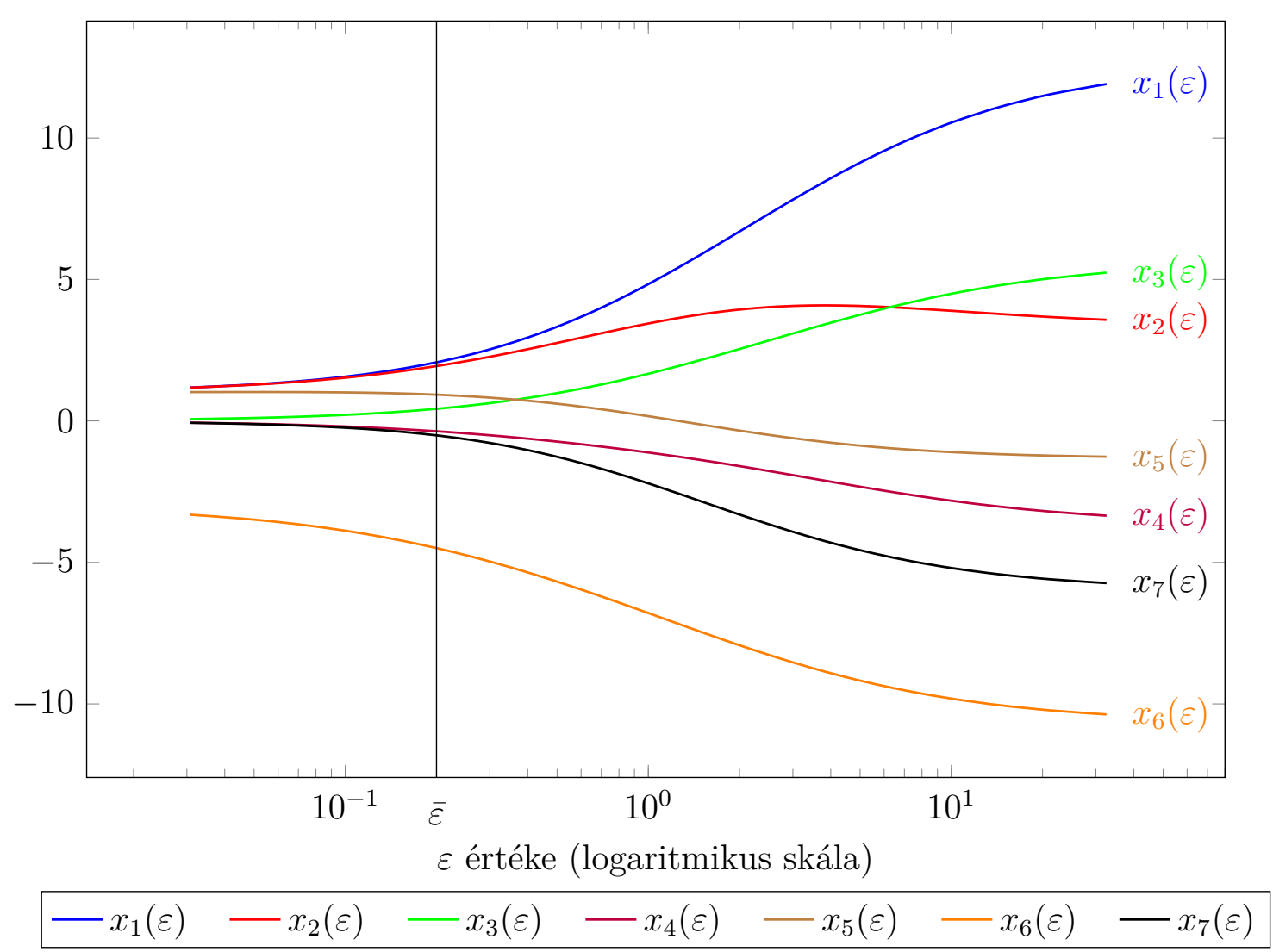

$n-1=6$, minimuma pedig $-(n-1)=-6$ (lásd még a 3.1. Állítást). Az $X_{1}$ objektum értékelése $X_{6}$-énál nagyobb abszolútértékü, ami indokolatlannak tűnhet, hiszen előbbi csak egy győzelemmel, utóbbi viszont három vereséggel rendelkezik.

Végül látható, hogy az általánosított sorösszeg által szolgáltatott értékelések nem $\varepsilon$ monoton függvényei - ahogy azt a 3.2. ábrán a piros vonal mutatja -, mert $x_{2}(1 / 2)<x_{2}(1)>\lim _{\varepsilon \rightarrow \infty} x_{2}(\varepsilon)$.

Amennyiben a 3.1. Példában csak a közvetlen ellenfelek értékelését szerepeltetjük, mint David (1987), akkor $X_{1}$ és $X_{2}$ között még holtverseny lesz, mert $X_{3}$ és $X_{4}$ pontszáma megegyezik.

A statisztikai becslés természetesen ennél jóval rugalmasabb. A $h_{i j}$ realizált különbség módosításával beépíthetők a nem szimmetrikus eredmények: $a_{i j} / m_{i j}$-hez egy pozitív konstans adható, amennyiben $X_{i}$ a priori előnyt élvezett az összehasonlítás során (például kézilabdában pályaválasztó volt, vagy sakkban világossal játszott). Ekkor $h_{i j} \neq h_{j i}$, de ez a becslésben nem okoz nehézséget, egyedül az $s_{i}$ pontszámok módosulnak (Stefani, 1980). A mérkőzések súlyozásához az összehasonlítások $m_{i j}$ számát kell változtatni, mondjuk a későbbieket szisztematikusan felülértékelve. Nem szükséges ragaszkodni a legkisebb négyzetes célfüggvényhez sem. Bassett (1997) a legkisebb abszolút eltérés optimalizálását javasolja: 


$$
\min _{\mathbf{q} \in \mathbb{R}^{n}} \sum_{X_{i}, X_{j} \in N} m_{i j}\left|h_{i j}-q_{i}+q_{j}\right|
$$

Ennek előnye, hogy kevésbé érzékeny a nagy különbségekre. A legkisebb négyzeteknél ugyanis $q_{i}=s_{i}+\sum_{X_{j} \in N} m_{i j} q_{j}=\sum_{X_{j} \in N} m_{i j}\left(a_{i j} / m_{i j}+q_{j}\right)$, ahol a zárójelben szereplő kifejezés az összehasonlítás várható eredményének átlaga, mely közismerten érzékeny a kiugró értékekre, outlierekre. A legkisebb abszolút eltérésnél viszont az átlag helyett a medián szerepel, ami sokkal robusztusabbá teszi (Bassett, 1997). Ez azonban áldozatokkal jár: miközben a megoldás létezéséhez itt is az összehasonlítási multigráf összefüggősége szükséges, annak egyértelmüsége nem garantált (Bassett, 1997). Utóbbi probléma esetleg kiküszöbölhető az összehasonlítások számának kismértékü megváltoztatásával (bár, miközben a sportban még elfogadható lehet a korábban játszott mérkőzések elhanyagolható mértékü leértékelése, a szavazók megkülönböztetése már nehezen védhető), zárt formulák hiányában azonban szinte lehetetlen az axiomatikus megközelítés alkalmazása - lényegében újra megjelennek az optimális lineáris rendezésnél említett problémák. Ugyanez elmondható gyakorlatilag minden más, nem a négyzetes eltérést tartalmazó célfüggvényről.

\subsection{A megoldás egyértelmüsége}

A megoldás egyértelműsége azért kívánatos, mert a döntéshozók nehezen tudnának értelmezni több, egymástól eltérő sorrendet. Ez az érv szintén a diszkrét optimalizálási problémaként történő kezelés ellen szól. Ugyanakkor az információtömörítési értelmezés alapján $n$ növekedésével egyre nagyobb valószínüséggel fordulhat elő, hogy az alternatívák teljesítménye nem mérhető egyetlen dimenzióban.

\subsubsection{A legkisebb négyzetek módszere}

A legkisebb négyzetek módszerére még nem mondtunk ki a 3.2. Állításhoz hasonló eredményt. Nem is tudunk, mert a Laplace-mátrixnak nem létezik inverze, hiszen a 2.1. Lemma szerint $\mu_{n}=0$, ezért felmerül a megoldás egyértelmüségének problémája. Ehhez némi előkészítés szükséges, elsőként a rangsorolási probléma és az összehasonlítási multigráfjának Laplace-mátrixával kapcsolatban.

3.2. Lemma. Legyen $(N, A, M) \in \mathcal{R}^{n}$ egy rangsorolási probléma. Ekkor ekvivalensek a következők:

1. az $M$ mérkőzésmátrix nem blokk diagonális;

2. a $G$ összehasonlítási multigráf összefüggö;

3. az L mátrix második legkisebb sajátértéke, $\mu_{n-1}$ pozitív. 
Bizonyítás. 1 és 2 ekvivalenciája nyilvánvaló: ha $M$ blokk diagonális, akkor nincs él az $N_{1}$ és $N_{2}$ objektumhalmazok között, és fordítva. A $2 \Leftrightarrow 3$ relációt Mohar (1991, Theorem 2.1) igazolja, megmutatva, hogy a $\mu_{n}=0$ sajátérték multiplicitása a $G$ gráf összefüggő komponenseinek számával egyezik meg.

A három feltétel közül a későbbiekben az összehasonlítási multigráf összefüggőségét használjuk.

3.4. Állítás. A legkisebb négyzetek módszerének q értékelövektora akkor és csak akkor egyértelmü, ha a $G$ összehasonlítási multigráf összefüggő, $(N, A, M) \in \mathcal{R}_{O}^{n}$.

Bizonyítás. Az $(N, A, M) \in \mathcal{R}_{U}^{n}$ súlyozatlan rangsorolási problémákra lásd Kaiser és Serlin (1978, 426. o.) és Bozóki et al. (2010, Theorem 4).

Általánosan Bozóki et al. (2014) látta be, bár - bizonyítás nélkül - Chebotarev és Shamis (1999, 220. o.) is említi ezt.

A feltétel jelentése világos: ha található két olyan objektum, melyek nem hasonlíthatók össze sem közvetlenül, sem közvetve, más objektumokon keresztül, akkor nem állítható fel egyértelmü rangsor.

3.4. Megjegyzés. Chebotarev (1994, Property 5) nulla feltevés (zero presumption) tulajdonsága értelmében az általánosított sorösszegre, valamint a definícióból a pontszám módszerre is érvényes, hogy egy, a többivel nem összehasonlított $X_{i} \in N$ objektum értékelése nulla: ha $m_{i j}=0$ minden $X_{j} \in N$-re, akkor $s_{i}(N, A, M)=$ $=x_{i}(N, A, M)=0$.

Ezek alapján, a 3.3. Állítás figyelembevételével, a legkisebb négyzetek módszerének egyértelműsége egy kiegészítő feltétellel is biztosítható.

1. Feltevés. Amennyiben $(N, A, M) \notin \mathcal{R}_{O}^{n}$, bontsuk szét a $G$ összehasonlítási multigráfot az összefüggő komponenseire, majd azokra külön-külön határozzuk meg a megoldást, az értékelések összegét minden esetben nullának választva.

Az előzőek szerint a pontszám és az általánosított sorösszeg értelmezési tartománya az $\mathcal{R}$ halmaz, a legkisebb négyzetek módszeréé pedig $\mathcal{R}_{O}$, ami azonban egyszerüen kiterjeszthető $\mathcal{R}$-re. Ugyanakkor ennek értelme kérdéses, hiszen bizonyos esetekben reménytelennek tűnik egy teljes rangsor felállítása: amennyiben két objektum között sehogyan sem található kapcsolat, akkor lehetetlen megállapítani sorrendjüket. Gondoljunk például arra, hogyan hasonlítanánk össze két UEFA-tagállam labdarúgó bajnokságának győzteseit, ha nem lennének nemzetközi versenysorozatok, a Bajnokok Ligája vagy az Európa Liga. 


\subsubsection{Más pontozási eljárások}

A pontozási eljárások által szolgáltatott egyértelmű megoldás létezése tekintetében alapvetően három előfeltételt különböztethetünk meg : ${ }^{6}$

1. Az $\mathbf{R}$ aggregált páros összehasonlítási mátrix irreducibilitása. Ez a szükséges és elégséges feltétel a maximum likelihood (Zermelo, 1929; Bradley és Terry, 1952), az invariáns és a fair bets módszer (Daniels, 1969; Moon és Pullman, 1970) esetén.

2. Az M mérkőzésmátrix irreducibilitása. Ez az előzőnél gyengébb feltétel szükséges és elégséges a legkisebb négyzetek módszer megoldásának egyértelmüségéhez.

3. Az értelmezési tartomány az egész $\mathcal{R}^{n}$ halmaz. Ez a helyzet a pontszám és az általánosított sorösszeg módszereknél, a maximum likelihood kiterjesztett változatánál (Conner és Grant, 2000), vagy a PageRanknél (Brin és Page, 1998).

A három közül intuitív alapon a második tűnik a legvonzóbbnak. Ha két alternatíva egyáltalán nem hasonlítható össze, akkor alaptalannak tűnik bármit mondani a relatív teljesítményükről. Másrészt az irreducibilitás megkövetelése aránytalanul korlátozza az egymással összevethető elemek halmazát. Bizonyos mértékben az e halmazon értelmezett pontozási eljárások is általánosíthatók az alábbiakban tárgyalt módon (Zermelo, 1929; Slutzki és Volij, 2005).

3.8. Definíció. Liga (league) : Az $R$ páros összehasonlítási mátrix egy tartalmazásra nézve maximális reducibilis blokkjához tartozó objektumhalmaza liga.

3.2. Példa. A 3.1. Példa objektumai egy ligát alkotnak.

3.9. Definíció. Ligák közötti dominancia (dominance between leagues): Az $R$ páros összehasonlítási mátrix $N^{1}$ ligája dominálja az $N^{2}$ ligát, ha bármely $X_{i} \in N^{1}$ és $X_{j} \in N^{2}$ objektumhoz létezik olyan $X_{i}=X_{k_{0}}, X_{k_{1}}, \ldots, X_{k_{T}}=X_{j}$ véges sorozat, hogy $\prod_{t=0}^{T-1} r_{k_{t}, k_{t+1}}>0$.

3.5. Megjegyzés. Az azonos ligába tartozó $X_{i}$ és $X_{j}$ objektumokra léteznek olyan véges $X_{k_{0}}, X_{k_{1}}, \ldots, X_{k_{T}}$ sorozatok, hogy $\prod_{t=0}^{T-1} r_{k_{t}, k_{t+1}}>0$ és $X_{k_{0}}=X_{i}, X_{k_{T}}=X_{j}$, illetve $X_{k_{0}}=X_{j}, X_{k_{T}}=X_{i}$.

3.2. Jelölés. Az $N^{1}$ és $N^{2}$ ligák közötti dominancia jele $N^{1} \rightarrow N^{2}$.

3.6. Megjegyzés. A ligák közötti dominancia egy irreflexív és tranzitív (de nem feltétlenül teljes) bináris reláció.

\footnotetext{
${ }^{6}$ Nem vizsgáljuk a játékelméletben javasolt módszereket, melyek többnyire a digráfok $\mathcal{D}^{n}$ halmazán értelmezettek.
} 
3.3. Példa. A 3.1. Példában az alábbi ligák közötti dominanciák érvényesek: $\left\{X_{1}\right\} \rightarrow\left\{X_{3}\right\} \rightarrow\left\{X_{5}\right\} \rightarrow\left\{X_{7}\right\} \rightarrow\left\{X_{6}\right\}$ és $\left\{X_{2}\right\} \rightarrow\left\{X_{4}\right\} \rightarrow\left\{X_{6}\right\}$.

A dominancia a ligák között egy természetes rendezést definiál, ez azonban nem teljes. Nyilvánvalóan kimaradnak belőle azok a ligák, melyek között az összehasonlítási multigráfban egyáltalán nem létezik él. A 3.9. Definíció alapján azonban két olyan liga objektumait sem tudjuk rangsorolni, melyek között közvetve ugyan teremthető kapcsolat az $M$ mérkőzésmátrixban, de ez valamilyen maximális mértékü $\left(r_{i j}=0\right.$ vagy $\left.r_{j i}=0\right)$ összehasonlítást is tartalmaz.

A 3.1. Példában az $\left\{X_{4}\right\}$ és $\left\{X_{5}\right\}$ ligák sorrendje a fenti a kiterjesztéssel sem állapítható meg, míg a pontszám, általánosított sorösszeg és legkisebb négyzetek módszerével igen. Egyetlen objektumból álló ligák esetén az azok közötti természetes rendezést kielégítő rangsorok megegyeznek az objektumok optimális lineáris rendezéséből adódóakkal, a 3.1. Példában 15 ilyen található. Ez Chebotarev (1994) egyik fő érve az általánosított sorösszeg (illetve ennek mintájára a pontszám és a legkisebb négyzetek módszere) alkalmazása mellett.

\section{4. Összegzés}

A 3.1. szakaszban pontozási eljárásokat mutattunk be. A név és az egyenlő módszer elsősorban didaktikai célokat szolgál, a pontszám módszer nem veszi figyelembe az ellenfelek erejét. Az általánosított sorösszeg $\varepsilon$ paramétere pedig a közvetett összehasonlítások jelentőségét tükrözi, egyik határértéke a pontszám módszer. Chebotarev (1994) alapján megadtunk egy erre vonatkozó feltételt (3.2. Állítás). A játékelméletben javasolt pozíciós erő digráfok csúcsait rangsorolja, de modellünkben is értelmezhető. Az általánosított sorösszeg másik határértéke a 3.2. alfejezetben ismertetett, statisztikai becslésként levezethető legkisebb négyzetek módszere.

A 3.3. részben a pontozási eljárások egyértelmű megoldhatóságával foglalkoztunk, elsőként a legkisebb négyzetek módszerével kapcsolatban (3.3.1. alfejezet), majd egy általános keretben (3.3.2. alfejezet). Véleményünk szerint az összehasonlítási multigráf összefüggősége a legáltalánosabb olyan feltétel, ami még megalapozza egy rangsor felállítását. Erre számos, az irreducibilis $R$ páros összehasonlítási mátrixra értelmezett módszer nem alkalmas, még a Zermelo (1929) nyomán ismertetett természetes kiterjesztés segítségével sem. Ez az egyik döntő érv az általunk választott módszerek - a pontszám, az általánosított sorösszeg és a legkisebb négyzetek - alkalmazása mellett (Chebotarev, 1994).

A fejezetben saját eredménynek tekinthető a legkisebb négyzetek és az $L L S M$ módszer ekvivalenciájának megmutatása, mely lehetővé teszi a páros összehasonlításokra ismert axiomatikus eredmények alkalmazását az AHP módszertanban. 
Ugyancsak saját hozzájárulás a megoldhatóságra vonatkozó feltételek tárgyalása és egymással történő összevetése.

Az általánosított sorösszeg hibája lehet, hogy még az $\varepsilon$ paraméter észszerű felső határa sem biztosít megfelelően nagy szerepet az ellenfeleknek, ahogy azt González-Díaz et al. (2014, Example 2.1) sugallja. Hasonlóan, a 3.1. Példában az objektumoknak több optimális lineáris rendezése létezik, ezeknél azonban $X_{3} \succ X_{5}$, miközben $X_{5} \succ{ }_{(N, A, M)}^{x(\varepsilon)} X_{3}$ minden $0<\varepsilon<1 / 5$ esetén. Ugyanakkor Chebotarev (1994, 306. o.) hangsúlyozza, hogy a 3.1. Állítás teljesülésének $0<\varepsilon \leq 1 /[m(n-2)]$ csak elégséges, de nem feltétlenül szükséges feltétele. A 3.5. Definícióban szereplő felső határ univerzális, kizárólag $n$-től és $m$-től függ, adott $R$ aggregált páros összehasonlítási mátrixra más, ennél nagyobb értékek is megengedettek lehetnek.

Szintén nyitott kérdés az általánosított sorösszeg $\varepsilon$ paraméterének megválasztása. Ennek egyik lehetséges útja gyakorlati alkalmazások vizsgálata, annak elemzése, milyen érték mellett szolgáltatja a módszer valamilyen szempontból a legjobb (például a maximális előrejelző erővel bíró) megoldást. 


\section{4. fejezet}

\section{A legkisebb négyzetek módszerének gráf interpretációja}

Still there are very few papers on indirect scoring procedures in the social choice theory. Probably, the reason is that these procedures are not arithmetically ascetic enough, and thereby, according to a widespread opinion, do not correspond to the non-quantitative nature of the social choice problem. Another problem is that they are not easy to describe to the individuals involved in the choice process.

Pavel Chebotarev és Elena Shamis, 1999

A pontozási eljárások elterjedését nagyban segítheti, ha a matematikai formula mellett valamilyen vonzó interpretáció is adható rá; többek között ez a PageRank módszer népszerüségének egyik alapja. Az általánosított sorösszeg módszerre Shamis (1994) két gráfokon történő értelmezést adott, az egyik azonban csak bizonyos $\varepsilon$ értékek mellett érvényes, és mindkettő meglehetősen bonyolult, mély gráfelméleti ismereteket követel. Az alábbiakban bemutatjuk a legkisebb négyzetek módszerének iteratív módon történő számítását az összehasonlítási multigráfon, melyet az általánosított sorösszegre is kiterjesztünk. Ez az értekezés egyik legfőbb hozzájárulása.

Irányított gráfok csúcsainak rangsorolására számos iteratív eljárás ismert, az egyik legkorábbi a Wei (1952) és Kendall (1955) által bevezetett, hosszú út módszernek (long-path method) nevezett eljárás (Laslier, 1997), mely az összefüggő digráf szomszédsági mátrixának maximális (domináns) sajátértékéhez tartozó egyetlen, szigorúan pozitív sajátvektor (Moon és Pullman, 1970). Ennek komoly hátrányaként említhető a korlátozott értelmezési tartomány (a digráf nem lehet körmentes) (Chebotarev, 1994; Herings et al., 2005), amire a 2. fejezetben ismertetett pozíciós erő kínál egy lehetséges megoldást. Ebben a szakaszban azt is megmutatjuk, hogy a legkisebb négyzetek módszerének gráf interpretációja szoros kapcsolatban áll az utóbbi módszer mögött meghúzódó gondolattal. 


\subsection{Az értékelővektor alternatív számítása}

A legkisebb négyzetek módszerének definíciója az egyértelmüség mellett felveti a kiszámíthatóság kérdését - a 3.3. Állítás felhasználása nem tűnik hatékonynak. A súlyozatlan esetben Gulliksen $\left(1956,127\right.$. o.) szerint az $L$ mátrix $L_{-1}$ első fóminorának általában létezik inverze. Ekkor a $q_{n}=0$ normalizálással elhagyható az utolsó egyenlet, így $\mathbf{s}$ és $\mathbf{q}$ első $n-1$ komponensét $\mathbf{s}_{-1}$-gyel és $\mathbf{q}_{-1}$-gyel jelölve, a megoldás a $\mathbf{q}_{-1}=$ $=\left[L_{-1}\right]^{-1} \mathbf{s}_{-1}$ egyenletrendszerből kapható: az $L \mathbf{q}=\mathbf{s}$ rendszer első $n-1$ egyenlete $q_{n}=0$ miatt biztosan teljesül, az $n$-edik pedig azért igaz, mert az $L$ mátrix első $n-1$ sorának összege éppen az utolsó ellentettje, illetve $\mathbf{s}_{-1}$ elemeinek összege is azonos $-s_{n}$-nel.

4.1. Megjegyzés. Egy körmérkőzéses rangsorolási problémában $d_{i}=k(n-1), k \in \mathbb{N}$ minden $X_{i} \in N$-re. Ekkor $\left[L_{-1}\right]^{-1}$ explicit módon is megadható, egy olyan $(n-1) \times$ $\times(n-1)$-es mátrix, melynek föátlójában $2 /(k n)$, azon kívül pedig $1 /(k n)$ szerepel (Gulliksen, 1956, 127. o.). Tehát $q_{i}=\sum_{j=1}^{n} a_{i j} /(k n)=s_{i} /(k n)$ minden $X_{i} \in N$ esetén, a legkisebb négyzetek módszere arányos a pontszámmal, az általuk generált rangsorok azonosak.

Most megadunk egy olyan eljárást, melynek révén a 3.7. Definíciót kielégítő megoldás $n \times n$-es mátrixokkal és $n$ dimenziós vektorokkal számítható ki. E tekintetben javaslatunk különbözik az eggyel kevesebb dimenziót használó Gulliksen (1956) és Bozóki et al. (2010) cikkektől, és Kaiser és Serlin (1978) megközelítésére hasonlít.

Először az $L$ mátrix minimális sajátértékét egy ismert perturbációval pozitívvá tesszük. Felhívjuk a figyelmet a 2.1. Jelölésre.

4.1. Lemma. Legyen $G$ egy összefüggő multigráf. Ekkor $\mu_{n-1}>0$, az $L+(1 / n) J$ mátrix sajátértékei $\mu_{1}, \mu_{2}, \ldots, \mu_{n-1}, 1$. Ha $L^{+}$az L Moore-Penrose általánositott inverze, akkor $[L+(1 / n) J]^{-1}=L^{+}+(1 / n) J$.

Bizonyitás. Ez a formula az irodalomban jól ismert, számos különböző cikkben találkozhatunk vele. Általunk ismert első megjelenése Sharpe és Styan (1965), lásd még Rao és Mitra (1971, Theorem 10.1.2), illetve Chebotarev és Agaev (2002, Proposition 15 és 16). Saját bizonyítást adunk.

A súlyozatlan esetre Gutman és Xiao (2004, Theorem 4 és 5) látta be.

Általános esetben a 3.2. Lemma miatt $\mu_{n-1}>0$. A Laplace-mátrix sajátvektorai választhatók úgy, hogy mindegyik valós, normalizált és bármely másikkal ortogonális legyen, míg a $\mu_{n}=0$ sajátértékhez tartozó $\mathbf{u}^{(n)}=[1,1, \ldots, 1]^{\top}, \mathbf{u}^{(n)} \in \mathbb{R}^{n}$. Mivel $\mathbf{u}^{(n)}$ mindegyik $\mathbf{u}^{(k)}, k=1,2, \ldots, n-1$ sajátvektorra ortogonális, minden $k=1,2, \ldots, n-1$-ra teljesül $\sum_{j=1}^{n} u_{j}^{(k)}=0$. Gutman és Xiao (2004, Theorem 4) eredményének multigráfokra történő kiterjesztése triviális, mert $[L+(1 / n) J] \mathbf{u}^{(k)}=$ $=L \mathbf{u}^{(k)}+(1 / n) J \mathbf{u}^{(k)}=L \mathbf{u}^{(k)}+\mathbf{0}=\mu_{k} \mathbf{u}^{(k)}$ minden $k=1,2, \ldots, n-1$-re és 
$[L+(1 / n) J] \mathbf{u}^{(n)}=L \mathbf{u}^{(n)}+(1 / n) J \mathbf{u}^{(n)}=\mathbf{0}+(1 / n) n \mathbf{u}^{(n)}=\mathbf{u}^{(n)}$, tehát $L+(1 / n) J$ utolsó sajátértéke 1 a hozzá tartozó $\mathbf{u}^{(n)}$ sajátvektorral.

Kwiesielewicz (1996) belátja, hogy a súlyozott esetben is fennáll $L L^{+}=L^{+}$ $+L=I-(1 / n) J$, következésképp $[L+(1 / n) J]\left[L^{+}+(1 / n) J\right]=L L^{+}+O+O+$ $+(1 / n)^{2} J^{2}=I-(1 / n) J+(1 / n)^{2} n J=I$, mert $J L^{+}=O$ (Kwiesielewicz, 1996, Theorem 4). Vagyis $[L+(1 / n) J]^{-1}=L^{+}+(1 / n) J$.

Tehát $l+(1 / n) J$ már invertálható, a $\mu_{n}=0$ sajátértéket 1 helyettesíti. Kaiser és Serlin (1978) az $L+J$ mátrixot használja a szingularitás kikerülésére.

4.1. Tétel. Legyen $(N, A, M) \in \mathcal{R}_{O}^{n}$ egy összefüggö rangsorolási probléma. A legkisebb négyzetek módszerének egyértelmü megoldása

$$
\mathbf{q}=L^{+} \mathbf{s}=[L+(1 / n) J]^{-1} \mathbf{s}
$$

Bizonyítás. A 4.1. Lemma alapján érvényes a következő ekvivalencia-sorozat:

$$
\begin{aligned}
L \mathbf{q}=\mathbf{s} & \Leftrightarrow[L+(1 / n) J] \mathbf{q}=\mathbf{s}+(1 / n) J \mathbf{q} \Leftrightarrow \\
& \Leftrightarrow \mathbf{q}=\left[L^{+}+(1 / n) J\right] \mathbf{s}+(1 / n)\left[L^{+}+(1 / n) J\right] J \mathbf{q} .
\end{aligned}
$$

Mivel $L^{+} J=O$ (Kwiesielewicz, 1996, Theorem 4), $J^{2}=n J$ és az $\mathbf{e}^{\top} \mathbf{s}=\sum_{i=1}^{n} s_{i}=0$ normalizálás következtében $J_{\mathbf{s}}=\left(\sum_{i=1}^{n} s_{i}\right) \mathbf{e}=\mathbf{0}$, így:

$$
L \mathbf{q}=\mathbf{s} \Leftrightarrow \mathbf{q}=L^{+} \mathbf{s}+(1 / n) J \mathbf{q}
$$

A $J \mathbf{q}=\mathbf{0}$ normalizálás csak akkor tehető meg, ha $J L^{+} \mathbf{s}=\mathbf{0}$, ami $J L^{+}=O$ miatt biztosan fennáll.

Az $L^{+}$általánosított inverz az $L^{+} L=L L^{+}=I-(1 / n) J$ egyenletből kapható, így megmarad az egyszerű kiszámíthatóság (Kwiesielewicz, 1996). A 4.1. Tétel elsősorban technikai eredmény, alkalmazási szempontból nincs különösebb jelentősége, viszont ez fog a következő szakaszban tárgyalt gráf interpretáció alapjául szolgálni.

\subsection{Az eljárás iteratív felbontása}

A következőkben egy iteráció fixpontjaként adjuk meg a legkisebb négyzetek módszerének értékelővektorát.

\subsubsection{A dekompozíció levezetése}

A legkisebb négyzetek módszerének felbontása a 4.1. Tételen és $[L+(1 / n) J]^{-1}$ Neumann-során (Neumann, 1877) alapul. 
4.2. Lemma. Legyen $B \in \mathbb{R}^{n \times n}$ egy mátrix. Ekkor a következők ekvivalensek:

1. $a \sum_{k=0}^{\infty} B^{k}=I+B+B^{2}+B^{3}+\ldots$ Neumann-sor konvergens;

2. B minden sajátértéke az egységkörön belül található, $\max \{|\lambda|: \lambda \mathbf{y}=B \mathbf{y}$, $\lambda \in \mathbb{R}\}<1$;

3. $\lim _{n \rightarrow \infty} B^{n}=O$.

Ekkor $(I-B)^{-1}$ létezik és

$$
(I-B)^{-1}=\sum_{k=0}^{\infty} B^{k}=I+B+B^{2}+B^{3}+\ldots
$$

Bizonyítás. Az állítás Meyer (2000, 618. o.) Neumann-sorra vonatkozó tételének speciális esete.

A q értékelővektor iteratív előállításához a Neumann-sort a 4.1. Tételben szereplő $L+(1 / n) J$ mátrixra kellene alkalmazni, ezért megvizsgáljuk annak sajátértékeit. Emlékeztetőül, $\mathfrak{d}=\max \left\{d_{i}: X_{i} \in N\right\}$ a maximális fokszám.

4.3. Lemma. Legyen $G$ egy gráf. Ekkor az $L$ mátrix minden sajátértékére $\mu_{k} \in$ $\in[0,2 \mathfrak{d}], k=1,2, \ldots n$.

Bizonyítás. A Geršgorin tételből (Geršgorin, 1931) következik.

4.4. Lemma. Legyen $G$ egy gráf $\mathfrak{d}=d_{1} \geq d_{2} \geq \ldots \geq d_{n}$ csökkenö fokszámsorozattal. Ekkor $\mu_{1} \leq 2 \mathfrak{d}$. Amennyiben $G$ összefüggö, egyenlöség akkor és csak akkor áll fenn, ha $G$ reguláris páros.

Bizonyítás. Tekintsük a $\mu_{1} \leq 2 \mathfrak{d}$ feltételt. A súlyozatlan esetet lásd Anderson és Morley (1985). Bizonyításuk egyszerüen átvihető multigráfokra, mert az $M$ mérkőzésmátrix nemnegatív (Mohar, 1991, 5. o.).

Az egyenlőségre vonatkozó feltétel Mohar (1991, Theorem 2.2 (b)) speciális esete. Ennek értelmében $\mu_{1} \leq \max \left\{d_{i}+d_{j}:\left(X_{i}, X_{j}\right) \in E\right\}$, ahol egyenlöség akkor és csak akkor áll fenn, ha $G$ félreguláris páros. Reguláris páros gráfban $\left(X_{i}, X_{j}\right) \in E$ esetén $X_{i} \in U$ és $X_{j} \in V$, egy él két végpontja a partíció két különböző oldalán található. Ekkor $\max \left\{d_{i}+d_{j}:\left(X_{i}, X_{j}\right) \in E\right\} \leq 2 \mathfrak{d}$, az egyenlötlenség pedig akkor és csak akkor teljesül, ha $d_{i}=d_{j}$, a fokszámok a két csoportban is azonosak, tehát $G$ reguláris.

4.1. Jelölés. $C=\mathfrak{d} I-L$.

A $C$ mátrix a fóátlón kívül azonos az $M$ mérkőzésmátrixszal, diagonális elemei azonban - a maximális számú összehasonlítással rendelkező objektumo(k) kivételével - megnövelésre kerültek, hogy minden sor (és oszlop) összege megegyezzen. Ekkor

$$
[L+(1 / n) J]^{-1}=[\mathfrak{d} I-C+(1 / n) J]^{-1}=\frac{1}{\mathfrak{d}}\left[I-\frac{1}{\mathfrak{d}}\left(C-\frac{1}{n} J\right)\right]^{-1} .
$$


4.2. Jelölés. $P=(1 / \mathfrak{d}) C$.

4.2. Megjegyzés. P egy duplán sztochasztikus mátrix: minden eleme nemnegatív, sorainak (és oszlopainak) összege 1.

4.2. Tétel. Legyen $(N, A, M) \in \mathcal{R}_{O}^{n}$ egy összefüggő rangsorolási probléma nem reguláris páros ${ }^{7} G$ összehasonlítási multigráffal. A legkisebb négyzetek módszerének egyértelmü megoldása

$$
\mathbf{q}=\frac{1}{\mathfrak{d}} \sum_{k=0}^{\infty} P^{k} \mathbf{s}=\frac{1}{\mathfrak{d}}\left(\mathbf{s}+P \mathbf{s}+P^{2} \mathbf{s}+P^{3} \mathbf{s}+\ldots\right)
$$

Bizonyítás. Legyen $\lambda$ az $(1 / \mathfrak{d})[C-(1 / n) J]$ mátrix sajátértéke a hozzá tartozó y sajátvektorral, azaz $\lambda \mathbf{y}=(1 / \mathfrak{d})[C-(1 / n) J] \mathbf{y}$. Ekkor

$$
\mathfrak{d}(1-\lambda) \mathbf{y}=\mathfrak{d}\{I-(1 / \mathfrak{d})[C-(1 / n) J]\} \mathbf{y}=[\mathfrak{d} I-C+(1 / n) J] \mathbf{y}=[L+(1 / n) J] \mathbf{y}
$$

Legyenek a Laplace-mátrix sajátértékei $\mu_{1}, \mu_{2}, \ldots, \mu_{n-1}, \mu_{n}$. A 4.1. Lemmából $\mathfrak{d}(1-$ $-\lambda) \in\left\{\mu_{1} ; \mu_{2} ; \ldots ; \mu_{n-1} ; 1\right\}$ és $\mu_{n-1}>0$, ezért $\mathfrak{d}(1-\lambda)>0$, vagyis $\lambda<1$. A 4.4. Lemma következtében $\mathfrak{d}(1-\lambda) \leq 2 \mathfrak{d}$, azaz $\lambda \geq-1$. A feltétel szerint $G$ összefüggő, nem reguláris páros multigráf, tehát $-1<\lambda<1$.

Tehát a $B=(1 / \mathfrak{d})[C-(1 / n) J]$ mátrixra alkalmazható a 4.2. Lemma. A 4.1. Tételben szereplő inverz Neumann-sorát felírva

$$
\begin{aligned}
\mathbf{q} & =[L+(1 / n) J]^{-1} \mathbf{s}=\frac{1}{\mathfrak{d}}\left[I-\frac{1}{\mathfrak{d}}\left(C-\frac{1}{n} J\right)\right]^{-1} \mathbf{s}= \\
& =\frac{1}{\mathfrak{d}} \sum_{k=0}^{\infty} B^{k} \mathbf{s}=\frac{1}{\mathfrak{d}} \sum_{k=0}^{\infty}\left(P-\frac{1}{\mathfrak{d} n} J\right)^{k} \mathbf{s} .
\end{aligned}
$$

Mivel $J \mathbf{s}=\mathbf{0}$, azaz $\{P-[1 /(\mathfrak{d} n)] J\}^{k} \mathbf{S}=P^{k} \mathbf{s}$, valóban teljesül a 4.2. Tétel.

A 4.2. Tétel szerint a legkisebb négyzetek módszerének megoldása egy vektorsorozat határértékeként kapható. Rangsorolási szempontból a q értékelővektor felbontásában szereplő $1 / \mathfrak{d}>0$ szorzónak nincs jelentősége.

4.1. Állítás. Legyen $(N, A, M) \in \mathcal{R}_{O}^{n}$ egy összefüggő rangsorolási probléma nem reguláris páros $G$ összehasonlítási multigráffal és

$$
\begin{gathered}
\mathbf{q}^{(0)}=(1 / \mathfrak{d}) \mathbf{s} \\
\mathbf{q}^{(k)}=\mathbf{q}^{(k-1)}+\frac{1}{\mathfrak{d}} P^{k} \mathbf{s}, \quad k=1,2, \ldots
\end{gathered}
$$

A legkisebb négyzetek módszerének egyértelmü megoldása $\mathbf{q}=\lim _{k \rightarrow \infty} \mathbf{q}^{(k)}$.

Bizonyítás. Közvetlenül adódik a 4.2. Tételből.

${ }^{7}$ A nem reguláris páros kifejezés jelentése, hogy a gráf nem lehet egyszerre reguláris és páros. 


\subsubsection{Az irodalom hasonló eredményei}

Gulliksen (1956) iteratív eljárása egy tetszőleges $\mathbf{r}$ közelítő megoldás $\mathbf{s}-L \mathbf{r}$ hibatagon keresztül történő kiigazításán alapul. Ezzel szemben a mi javaslatunk első becslésként az s pontszámvektort használja, amit az ellenfelek, majd az ellenfelek ellenfeleinek stb. pontszámával korrigál.

A rekurzív Buchholz módszer (González-Díaz et al., 2014) az $R$ páros összehasonlítási mátrix alapján az átlagokból, a $d_{i}=\sum_{j=1}^{n} m_{i j}$ fokszámokkal osztott s' módosított pontszámokból és az $M^{\prime}$ korrigált mérkőzésmátrixból indul ki. A teljesen különböző koncepció ellenére a rekurzív Buchholz módszer által generált rangsor arányos a legkisebb négyzetekből kapottal, előbbi éppen a q vektor felét adja (González-Díaz et al., 2014, Proposition 3.1).

A rekurzív Buchholz eljárás a szintén iteratív alapú rekurzív teljesítmény módszercsalád (Brozos-Vázquez et al., 2008) speciális esete. Ennek egyértelmüsége akkor biztosított, ha az $M$ mérkőzésmátrix nem blokk diagonális (a 3.2. Lemma szerint a $G$ összehasonlítási multigráf összefüggo”) és nem blokk antidiagonális (a 2.2. Lemma szerint $G$ nem páros gráf). A 3.4. Állítás értelmében előbbi a legkisebb négyzetek egyértelmüségéhez is szükséges, a másik feltétel azonban némi magyarázatot igényelhet. Egy blokk antidiagonális $M$ mátrix csapatbajnokságra emlékeztet: az objektumok (játékosok) két diszjunkt csoportba (csapat) oszthatók úgy, hogy egy csapat játékosai sem játszottak saját csapatuk többi tagja ellen. Ekkor az egyik csapat játékosainak értékelése csak a másik tagjai teljesítményének ismeretében határozható meg, és fordítva, ami meghiúsítja az iteráció konvergenciáját. Dekompozíciónkban ehhez hasonló probléma lép fel a reguláris páros gráfok esetén, ami az $M$ mérkőzésmátrix blokk antidiagonalitásának speciális esete.

Chebotarev (1994) az $\varepsilon$ paraméter hatványainak segítségével adja meg az általánosított sorösszeg módszer egy dekompozícióját. Emlékeztetőül, $\mu_{1}$ a Laplace-mátrix legnagyobb sajátértéke.

4.2. Állítás. Tetszőleges $0<\varepsilon<1 / \mu_{1}$-re az általánositott sorösszeg értékelővektora:

$$
\begin{aligned}
\mathbf{x}(\varepsilon) & =\left[\sum_{k=0}^{\infty} \varepsilon^{k}(-L)^{k}\right](1+\varepsilon m n) \mathbf{s}= \\
& =(1+\varepsilon m n) \mathbf{s}-\varepsilon L(1+\varepsilon m n) \mathbf{s}+\varepsilon^{2} L^{2}(1+\varepsilon m n) \mathbf{s}-\varepsilon^{3} L^{3}(1+\varepsilon m n) \mathbf{s}+\ldots
\end{aligned}
$$

Bizonyítás. Lásd Chebotarev (1994, Property 12).

Speciálisan $X_{i} \in N$-re

$$
x_{i}=s_{i}+\varepsilon\left[\left(m n-d_{i}\right) s_{i}+\sum_{X_{j} \neq X_{i}} m_{i j} s_{i}\right]+o(\varepsilon) .
$$




\subsection{3. Értelmezés}

A 4.1. Állítás iteratív folyamata szemléletesen értelmezhető gráfokon. A leírásban eltekintünk a rangsor szempontjából irreleváns $1 / \mathfrak{d}$ szorzótól.

4.1. Definíció. Kiegyensúlyozott összehasonlítási multigráf (balanced comparison multigraph): A $G^{\prime}$ kiegyensúlyozott összehasonlítási multigráf azonos a $G$ összehasonlítási multigráffal, de minden $X_{i} \in N$ csúcsnál $\mathfrak{d}-d_{i}$ darab hurokélt is tartalmaz.

Ezzel a módosítással minimális számú hurokéllel teremthető meg a kiegyensúlyozottság, legalább egy csúcs (a maximális fokszámú) hurokél nélküli. A 4.2. Tétel szerinti kritikus esetben, amikor $G$ reguláris páros gráf, egyáltalán nincs szükség hurokélekre, $G^{\prime}=G$. A két gráf egyszerre összefüggő, illetve reguláris páros. $G^{\prime}$ előállítása ekvivalens egy $G$ súlyozott gráf hurkokkal való kiegyensúlyozásával (Chebotarev, 2012, 1495. о.), ahol $G^{\prime}$ a $G$ kiegyensúlyozó gráfja (balance-graph).

Kezdetben minden objektum (csúcs) értékelése saját teljesítményének mérőszámával, $s_{i}$-vel egyezik meg. Az első lépésben ellenfeleinek erejét vesszük figyelembe a $G^{\prime}$ kiegyensúlyozott összehasonlítási multigráf élein keresztül: a $P$ s vektor megadja a vizsgált objektummal összehasonlítottak átlagos - az összehasonlításokat reprezentáló élek számával súlyozott - pontszámát. A o $-d_{i}$ darab hurokél bevezetése miatt az 1 hosszúságú úton elérhető csúcsok száma pontosan do. Az így definiált korrekciós tényezőt az eredeti pontszámhoz adva kapjuk az $\mathbf{s}+P \mathbf{s}$ értékelést.

A $k$-adik lépésben a korábbi értékeléshez a $k$ hosszúságú úton elérhető objektumok átlagos pontszámát, a $P^{k}$ s vektort adjuk hozzá. Amennyiben $G$ összefüggő és nem reguláris páros multigráf, a 4.2. Tétel alapján ez az eljárás a legkisebb négyzetek módszeréhez konvergál.

4.1. ábra. A 3.1. Példa kiegyensúlyozott összehasonlítási multigráfja

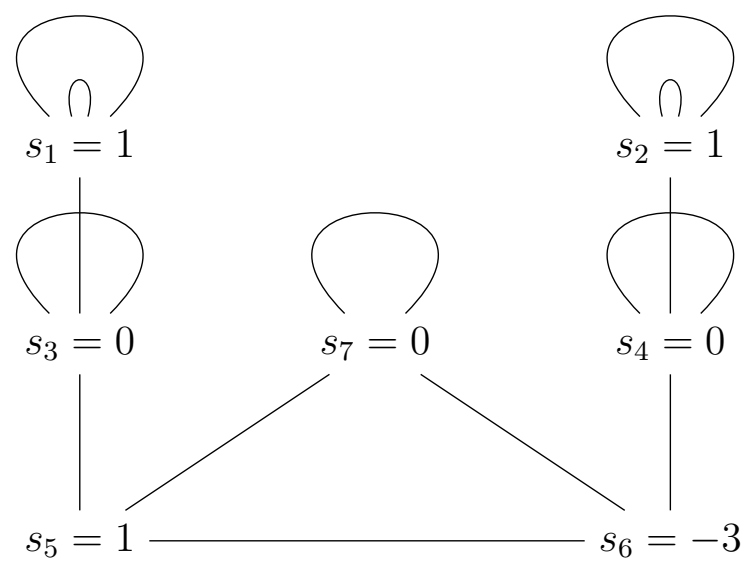

4.1. Példa. Tekintsük a 3.1. Példát, melynek kiegyensúlyozott összehasonlítási multigráfja a 4.1. ábrán látható. Utóbbi egy irányítatlan gráf, az egyes csúcsok 
hurokéleinek számát a $\mathfrak{d}-d_{i}$ különbségek határozzák meg: [2, 2, 1, 1, 0, 0, 1]. A csúcsok címkéje a megfelelő objektum $s_{i}$ pontszáma, ez képezi az iteráció alapját. Kezdetben az értékelővektor $\mathbf{d} \mathbf{q}^{(0)}$, minden csúcs a saját pontszámát kapja meg, ami $X_{1} \in N$-re $s_{1}=1$. Az első lépésben ( $\left(\mathbf{q}^{(1)}\right)$ ehhez adjuk hozzá az 1 hosszú úton elérhető csúcsok pontszámának összegét az $1 / \mathfrak{d}=1 / 3$ szorzóval. Például $X_{1}$ esetén ez $\left(2 s_{1}+s_{3}\right) / \mathfrak{d}=2 / 3$. A második lépésben $\left(\mathfrak{d} \mathbf{q}^{(2)}\right)$ a 2 hosszú úton elérhetö csúcsok pontszámának összegét adjuk a korábbi értékelővektorhoz az $(1 / \mathfrak{d})^{2}=1 / 9$ szorzóval, ami $X_{1}$-nél $\left(5 s_{1}+3 s_{3}+s_{5}\right) / \mathfrak{d}^{2}=6 / 9=2 / 3$.

4.2. ábra. A 4.1. Példa q értékelővektorának közelítése

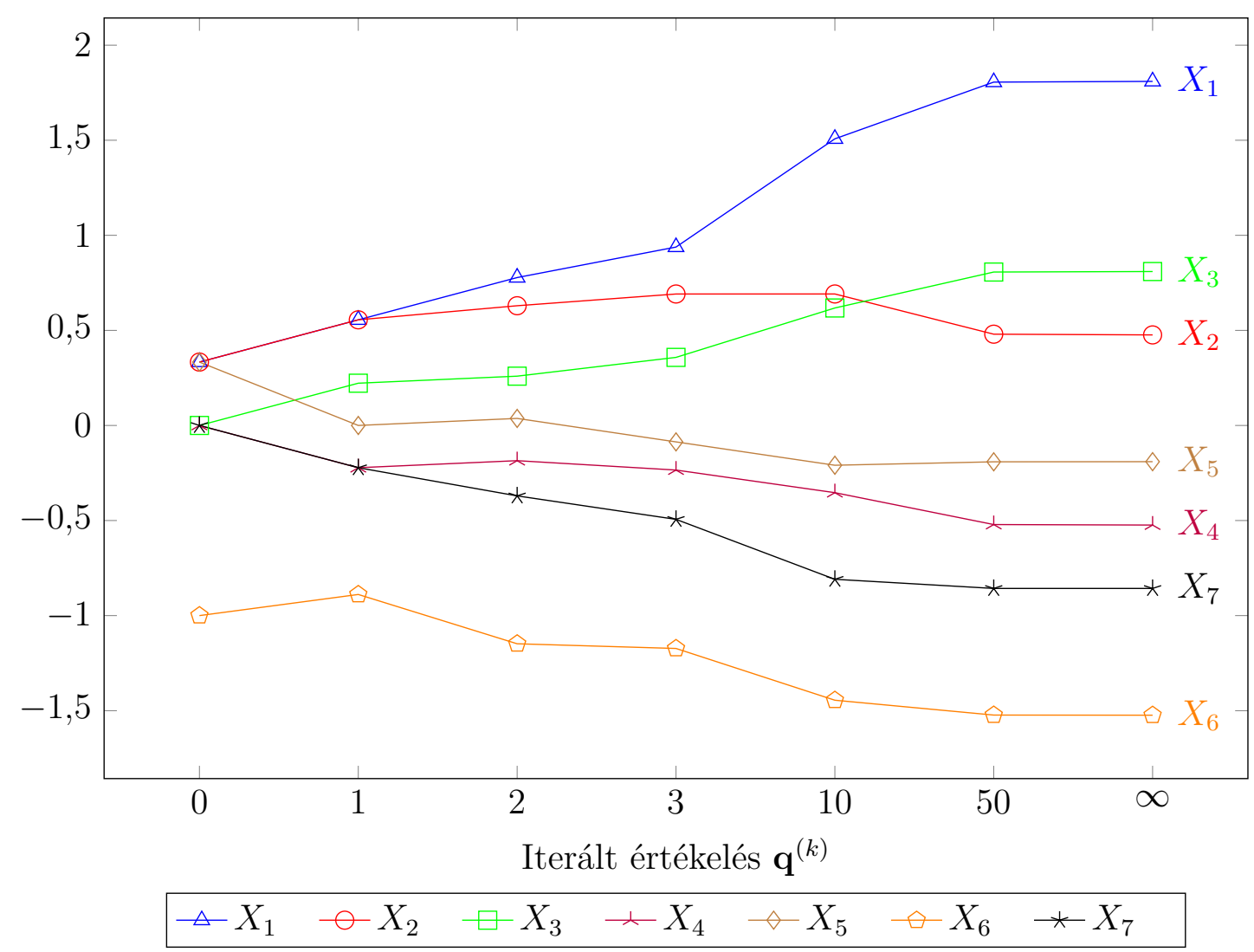

A $k$-adik iterációs lépésben a megelőző értékeléseket a $k$ hosszú úton elérhető objektumok átlagos összpontszámával módosítjuk, amit az $(1 / \mathfrak{d})^{k}$ szorzóval érünk el. Ennek megfelelően az aktuális $\mathbf{q}_{i}^{(k)}$ súly nevezője, egyszerüsítés hiányában, $\mathfrak{d}^{k+1}$ minden $X_{i} \in N$-re. A 4.2. Tétel szerint az iterációs folyamatnak létezik határértéke, hiszen $G$ nem reguláris páros gráf. A végső értékeléseket még 1/o-val meg kell szorozni, bár ez a sorrendet nem befolyásolja.

Az iteráció néhány lépésében kapott $\mathbf{q}^{(k)}$ értékelővektorok elemei a 4.2. ábrán láthatók; a felbontás az ellenfelek szerepét mutatja. Például $X_{1}, X_{2}$ és $X_{5}$ pontszáma azonos, miközben a preferencia gráfban (3.1. ábra) elfoglalt helyzetük jelentősen eltér. A dekompozíció fokozatosan felfedi, hogy $X_{1}$ ellenfelei erősebbek (magasabb pontszámmal rendelkeznek), mint az $X_{5}$-tel összehasonlított objektumok. A kiindulási 
rangsor $\left(X_{1} \sim X_{2} \sim X_{5}\right) \succ\left(X_{3} \sim X_{4} \sim X_{7}\right) \succ X_{6}$. Ezzel szemben az első lépést követöen $\left(X_{1} \sim X_{2}\right) \succ X_{3} \succ X_{5} \succ\left(X_{4} \sim X_{7}\right) \succ X_{6}, X_{3}$ megelőzi $X_{4}$-et, $X_{5}$-öt és $X_{7}$-et. A második lépés megszünteti a holtversenyeket, a sorrend $X_{1} \succ X_{2} \succ X_{3} \succ$ $\succ X_{5} \succ X_{4} \succ X_{7} \succ X_{6}$ lesz. Ez majdnem azonos a végső rangsorral, kivéve $X_{2}$ és $X_{3}$ relációját, ami csak a 13. lépésben alakul ki: $q_{2}^{(12)}>q_{3}^{(12)}$, de $q_{2}^{(13)}<q_{3}^{(13)}$. Ezután már nem változik az $X_{1} \succ X_{3} \succ X_{2} \succ X_{5} \succ X_{4} \succ X_{7} \succ X_{6}$ sorrend.

A 4.1. Példa alapján két megfigyelést tehetünk. Az első, hogy az ellenfelek erejének figyelembevétele általában eldönti a pontszámban jelentkező holtversenyeket, ami a gyakorlati alkalmazások szemszögéből előnyös lehet. Ugyanakkor a legkisebb négyzetek módszere nem egyszerüen a pontszám finomítása, hiszen például $s_{3}<$ $<s_{5}$, viszont $q_{3}>q_{5}$. Másrészt a konvergencia meglehetősen lassú lehet, a hosszú utak szükségességének indoklása pedig problémás, mert nem világos, miért van jelentőségük az ilyen áttételes ellenfeleknek. Többek között ezért marad meg David (1987) a közvetlen ellenfelek figyelembevételénél. Megjegyzendő, hogy a 3.1. ábra gráfja egy körmérkőzéses rangsorolási problémához képest meglehetősen kevés élt tartalmaz, a 21 lehetséges páros összehasonlításból mindössze hét ismert.

A reguláris páros összehasonlítási multigráf esetét az F.I. Függelékben tárgyaljuk.

\subsection{4. Összevetés más pontozási eljárásokkal}

A 3.6. Definíció alapján a pozíciós erő egy iteratív pontozási eljárás. A Herings et al. (2005, Lemma 4.2) által adott dekompozíció - az explicit említés hiánya ellenére - szintén a Neumann-sor használatán alapul, mert a 4.2. Lemma értelmében $\lim _{k \rightarrow \infty} T^{k}=O$ következtében

$$
I-(1 / n) T=I+\sum_{k=1}^{\infty}(1 / n)^{k} T^{k}
$$

E közös gyökerek mellett a legkisebb négyzetek és a pozíciós erő módszerek között három alapvető különbséget fedezhetünk fel. Egyrészt Chebotarev és Shamis (1999) meghatározása szerint az előbbi egy győzelem-vereség egyesítő, azokat egyenlően kezelő, az utóbbi viszont győzelem-vereség kombináló, azokat szigorúan megkülönböztető eljárás: míg q-ban a páros összehasonlítások eredménye csak közvetetten, az $A$ eredménymátrixon, ezáltal az s pontszámon keresztül érvényesül, a pozíciós erő definíciója közvetlenül tartalmazza az irányított gráf $T$ szomszédsági mátrixát.

A második eltérés a korábbi értékelések szerepe. A 4.1. Állítás értelmében a legkisebb négyzetek módszerénél ezek az adott csúcsnál maradnak, míg a pozíciós erőnél az elődök között kerülnek szétosztásra. Ezzel szemben az előbbi a végig változatlan $\mathbf{s}$ vektort használja a kiigazításhoz, utóbbi viszont minden lépésben hozzáadja a csúcsokhoz a kezdeti Te értékeléseket. 
A harmadik, talán legérdekesebb különbség a paraméterválasztásban érhető tetten. A pozíciós erőnél a követők fontosságát tükröző tényező értékére Herings et al. (2005) az 1/a =1/n definícióval, a csúcsok számának reciprokával él, noha a levezetésből világos, hogy az eljárás konvergenciáját már tetszőleges 1/( $n-1)$-nél kisebb szám biztosítaná. ${ }^{8}$ A 4.2. Tétel szerint a legkisebb négyzetek módszerében szereplő $1 / \mathfrak{d}$ diszkonttényező endogén módon meghatározott a $\mathfrak{d}=\max \left\{d_{i}: i=\right.$ $=1,2, \ldots, n\}$ képlettel az összehasonlítások maximális száma által, így az iteráció biztosan konvergens, ha a $G$ összehasonlítási multigráf összefüggő és nem reguláris páros. A bizonyítás tetszőleges $1 / \delta<1 / \mathfrak{d}$ paraméter mellett működik, aminek $\mathfrak{d} \leq$ $\leq m(n-1)$ miatt elégséges feltétele $\delta>m(n-1)$. Herings et al. (2005) javaslatának analóg változata $\delta=m n$, ami nyilvánvalóan eltér a legkisebb négyzetek módszerétől.

4.3. Állítás. Legyen $(N, A, M) \in \mathcal{R}_{O}^{n}$ egy összefüggő rangsorolási probléma nem reguláris páros $G$ összehasonlítási multigráffal, $c>\mathfrak{d}$ és

$$
\begin{gathered}
\mathbf{w}^{(0)}(\delta)=\frac{1}{\mathfrak{d}} \mathbf{s}, \\
\mathbf{w}^{(k)}(\delta)=\mathbf{w}^{(k-1)}(\delta)+\frac{1}{\mathfrak{d}}\left(\frac{1}{\delta} C\right)^{k} \mathbf{s}, \quad k=1,2, \ldots
\end{gathered}
$$

Ekkor létezik a $\mathbf{w}(\delta)=\lim _{k \rightarrow \infty} \mathbf{w}^{(k)}(\delta)$ határérték.

Bizonyítás. Alkalmazható a 4.2. Tétel bizonyítása, ahol $\delta>\mathfrak{d}$ következtében $\delta(1-$ $-\lambda)<\mu_{1}$, így $-1<\lambda<1$ miatt teljesül a 4.2. Lemma feltétele.

Ugyanakkor a hurokélek $\delta>\mathfrak{d}$ esetén sem tünnek el, a gráf interpretáció pedig nehezebben indokolhatóvá válik.

4.3. Megjegyzés. A 4.2. Tétel $1 / \delta$ diszkonttényezője $\delta=\mathfrak{d}$-val endogén módon adott a Laplace-mátrix $L=\mathfrak{d} I-C$ felbontása révén. Ha $1 / \delta$ ennél nagyobb, a Neumann-soros dekompozíció nem feltétlenül érvényes, a reguláris páros gráfon kívül más esetek is problémássá válhatnak, az $L$ mátrix $\mu_{1}$ maximális sajátértéke külön vizsgálandó.

A legkisebb négyzetek módszerének bemutatott felbontása, hurokélek hiányában, legjobban reguláris összehasonlítási multigráfok - azaz kiegyensúlyozott rangsorolási problémák, $(N, A, M) \in \mathbb{R}^{B}$ - esetén indokolható. Ezek több alkalmazási területen, például svájci rendszerü bajnokságokban, jellemzően előfordulnak, miközben minimális annak esélye, hogy az összehasonlítási multigráf páros.

A $\mathbf{q}=L^{+} \mathbf{s}$ lineáris egyenletrendszer alapján a legkisebb négyzetek módszerének más gráfokon történő értelmezései is lehetségesek: Chebotarev és Shamis (1998b, Theorem 3) az $L^{+}$általánosított inverz egy topologikus interpretációját adja.

${ }^{8}$ Érdekes kérdés, vajon az 1/a paraméter mennyire növelhetö. Herings et al. (2005, Theorem 3.1) bizonyítása biztosan múködik, amennyiben minden csúcsnak $a$-nál kevesebb utódja van. Ezáltal $1 / a$ pontos definíciója - a legkisebb négyzetek módszeréhez hasonlóan - itt is endogénné tehető a digráf szerkezetének figyelembevételével. 


\subsection{A gráf interpretáció általánosítása}

A legkisebb négyzetek módszerének a 4.2.1. szakaszban bemutatott iteratív előállítása, a 4.3. Állítás alapján, tetszőleges donál nagyobb diszkonttényezőre értelmezhető. Ezáltal egy, az általánosított sorösszeghez hasonló módszercsaládot kapunk, melynek határértéke a legkisebb négyzetek. A gráf interpretáció szerint a pontszámot a $C$ mátrix hatványai által képviselt, az ellenfelekhez vezető utak korrigálják. Az irodalomban szokásos feltételezés, hogy ezek fontossága a hosszúsággal exponenciálisan csökken (lásd például Katz (1953)), így a nagyon távoli ellenfelek jelentősége elhanyagolhatóvá válik. Esetünkben, a hurokélek előfordulása miatt, a közeli objektumok szerepe enélkül is nagyobb lehet, mégis érdemes megfontolni ezt az általánosítást.

4.2. Definíció. Általánosított Buchholz módszer (generalised Buchholz method): $\mathbf{w}(\delta): \mathcal{R}^{n} \rightarrow \mathbb{R}^{n}$, ahol

$$
\mathbf{w}(\delta)=\frac{1}{\mathfrak{d}} \sum_{k=0}^{\infty}\left(\frac{1}{\delta} C\right)^{k} \mathbf{s}=\frac{1}{\mathfrak{d}}\left[\mathbf{s}+\frac{1}{\delta} C \mathbf{s}+\left(\frac{1}{\delta} C\right)^{2} \mathbf{s}+\left(\frac{1}{\delta} C\right)^{3} \mathbf{s}+\ldots\right]
$$

tetszőleges $(N, A, M) \in \mathcal{R}^{n}$ rangsorolási probléma esetén. ${ }^{9}$

Emlékezetezőül, $C=\mathfrak{d} I-L$ és $\delta>\mathfrak{d}$ egy paraméter. A pontozási eljárás elnevezése a rekurzív Buchholz (González-Díaz et al., 2014) és a legkisebb négyzetek módszerének ekvivalenciájára utal. Előbbi a svájci rendszerű versenyeken jelentkező holtversenyek eldöntésére szolgáló egyik elterjedt szabály, az ellenfelek pontszámának megfelelő Buchholz-rendszer ${ }^{10}$ végtelen kiterjesztése. Itt ennek további általánosításáról van szó, a távolabbi ellenfelek kisebb jelentőségével, az általánosított rekurzív Buchholz elnevezést azonban túl hosszúnak találtuk.

4.4. Állítás. Az általánosított Buchholz módszernek minden $(N, A, M) \in \mathcal{R}^{n}$ rangsorolási probléma mellett egyértelmü megoldása létezik.

Bizonyítás. A 4.3. Állításból adódik.

4.5. Állítás. Az általánosított Buchholz módszer $\mathbf{w}(\delta)$ értékelövektora a következö egyenletrendszer egyértelmü megoldása:

$$
\mathfrak{d}\left(\frac{\delta-\mathfrak{d}}{\delta} I+\frac{1}{\delta} L\right) \mathbf{w}(\delta)=\mathbf{s}
$$

${ }^{9} \mathrm{Az}$ 1/d szorzónak a rangsorolás szempontjából nincs jelentősége, ezért változatlanul hagytuk.

10 A számos sportágban, például a sakkban használt módszer (FIDE, 2014) kidolgozása Bruno Buchholz nevéhez füződik (1932), bár az eredeti cikket nem sikerült megtalálnunk. Lásd még González-Díaz et al. (2014). 
Bizonyítás. A 4.2. Definícióból adódik, mert a $C=\mathfrak{d} I-L$ azonosság és a 4.2. Lemma alkalmazásával (ami a 4.3. Állítás szerint megtehető):

$$
\mathbf{w}(\delta)=\frac{1}{\mathfrak{d}} \sum_{k=0}^{\infty}\left(\frac{1}{\delta} C\right)^{k} \mathbf{s}=\frac{1}{\mathfrak{d}} \sum_{k=0}^{\infty}\left(\frac{\mathfrak{d}}{\delta} I-\frac{1}{\delta} L\right)^{k} \mathbf{s}=\frac{1}{\mathfrak{d}}\left[\left(1-\frac{\mathfrak{d}}{\delta}\right) I+\frac{1}{\delta} L\right]^{-1} \mathbf{s} .
$$

4.4. Megjegyzés. Az általánosított Buchholz módszer határértéke arányos a legkisebb négyzetek módszerével, ha $\delta \rightarrow \mathfrak{d}$, sőt, $\lim _{\delta \rightarrow \mathfrak{o}} \mathbf{w}(\delta)=\mathbf{q}$. Az általánosított Buchholz módszer határértéke arányos a pontszám módszerrel, ha $\delta \rightarrow \infty$, sőt, $\lim _{\delta \rightarrow \infty} \mathbf{w}(\delta)=$ $=(1 / \mathfrak{d}) \mathbf{s}$.

4.3. Tétel. Legyen $(N, A, M) \in \mathcal{R}^{n}$ egy rangsorolási probléma. Az általánosított Buchholz és az általánositott sorösszeg módszer arányos, a $\mathbf{w}(\delta)$ és $\mathbf{x}(\varepsilon)$ vektorok megfelelő $\delta$ és e paraméterválasztással egymás pozitív konstansszorosai:

$$
\begin{aligned}
& \mathbf{x}(\varepsilon)=\left(1+\frac{m n}{\delta-\mathfrak{d}}\right) \frac{\delta}{\mathfrak{d}(\delta-\mathfrak{d})} \mathbf{w}(\delta) \quad h a \varepsilon=1 /(\delta-\mathfrak{d}), e ́ s \\
& \mathbf{w}(\delta)=\frac{1}{1+\varepsilon m n} \frac{\mathfrak{d}}{1+\varepsilon \mathfrak{d}} \mathbf{x}(\varepsilon) \quad h a \delta=1 / \varepsilon+\mathfrak{d} .
\end{aligned}
$$

Bizonyítás. Tekintsük a két módszert definiáló lineáris egyenletrendszereket:

$$
\mathfrak{d}\left(\frac{\delta-\mathfrak{d}}{\delta} I+\frac{1}{\delta} L\right) \mathbf{w}(\delta)=\mathbf{s} \quad \text { és } \quad(I+\varepsilon L) \mathbf{x}(\varepsilon)=(1+\varepsilon m n) \mathbf{s} .
$$

$\mathrm{Az}(1+\varepsilon m n)$ tényezőtől eltekintve a két eljárás azonos, amennyiben az $I$ és $L$ mátrixok együtthatói egymás konstansszorosai, azaz

$$
\varepsilon=\frac{\mathfrak{d}}{\delta}: \frac{\mathfrak{d} \delta-\mathfrak{d}^{2}}{\delta}=\frac{1}{\delta-\mathfrak{d}} \quad \text { és } \quad \delta=\frac{1}{\varepsilon}+\mathfrak{d} .
$$

Ebből $(1+\varepsilon m n)$-nel korrigálva kapjuk az állítást.

4.5. Megjegyzés. A 3.5. Definíció alapján az általánosított sorösszeg észszerü paraméterválasztása $0<\varepsilon \leq 1 /[m(n-2)]$. Ez szemléletesebben értelmezhető az általánosított Buchholz módszernél, ahol a megfelelő feltétel

$$
\delta \geq m(n-2)+\mathfrak{d}
$$

Miután $\mathfrak{d} \leq m(n-1)$ minden $(N, A, M) \in \mathcal{R}^{n}$ rangsorolási problémára, ez gyakorlatilag azt jelenti, hogy az iteráció egyes lépéseiben nem az ellenfelek átlagos pontszámával (mint a legkisebb négyzetek módszerénél), hanem annak legfeljebb a felével kell korrigálni a pontszámot, mert jellemzően $\delta \geq 2 \mathfrak{d}$. Amennyiben $\mathfrak{d}$ jelentősen 
kisebb a maximális értékénél, ennél nagyobb lesz $\delta$ alsó határa is: a 3.1. Példában $m=1, \mathfrak{d}=3$ és $n=7$, azaz $\delta \geq 8$. Az eltérés különösen nagy, ha $\mathfrak{d} \ll m(n-2)$.

Érdemes összevetni a fenti gráf interpretációt az általánosított sorösszegre adott másik változattal (Shamis, 1994). Utóbbi szerint az $X_{i}$ objektum értékelésénél ugyanúgy az $X_{j}$-hez való közelség mértékében vesszük figyelembe annak pontszámát, azonban mindkét értelmezés helyességének belátása mély gráfelméleti ismereteket követel. Véleményünk szerint a fent bemutatott módszer gráfelméleti szempontból vonzóbb, egyszerüségében a PageRank értelmezésével vetekszik, bár a hurokélek megjelenése kétségtelenül nehezen magyarázható.

A 4.3. Tétel segítségével tehát egy új, Shamis (1994) megközelítésétől eltérő gráf interpretációt adtunk az általánosított sorösszeg eljárásra, mely jól mutatja annak a pontszám és a legkisebb négyzetek módszere közötti elhelyezkedését. Az x $(\varepsilon)$ értékelővektor számítása a 4.1. Példában látotthoz hasonló iteratív eljárással is elvégezhető, mindössze az ellenfelek fontosságát kell a paraméter értékének megfelelően módosítani. Ennek a 3.3. Megjegyzés értelmében algoritmikus szempontból nincs jelentősége, azonban a rangsor kialakulásának megértését nagymértékben segítségheti.

Vagyis, míg Chebotarev (1994) az általánosított sorösszeget függvényeken keresztül, a páros összehasonlítások eredményének aggregációjával szemben támasztott axiomatikus elvekből kiindulva definiálta, mi egy gráf interpretáción keresztül jutottunk ehhez a javaslathoz.

\section{4. Összegzés}

Az előzőekben bemutattuk az általánosított sorösszeg és a legkisebb négyzetek módszerének számítását a kiegyensúlyozott összehasonlítási multigráf segítségével, az utóbbinál egy, az F.I. Függelékben tárgyalt rendhagyó eset kivételével. Az értékelővektor a pontszámokon és az $1 / \delta \leq 1 / \mathfrak{d}$ diszkonttényezőn alapuló iteratív eljárással kapható meg, ahol $\mathfrak{d}=\max \left\{d_{i}: i=1,2, \ldots, n\right\}$ az egy objektumra eső összehasonlítások maximális száma, mely a mérkőzésmátrix révén endogén módon adott. Ha a $G$ összehasonlítási multigráf nem reguláris páros, a diszkonttényező értéke növelhető.

A 4.1. részben a Laplace-mátrix módosításával jutottunk el a q értékelővektor egy inverz mátrixszal történő felírásához, majd a 4.2. alfejezetben ennek alapján megmutattuk a legkisebb négyzetek módszerének gráfokon történő interpretációját. A 4.2.1. szakaszban a Neumann-soros dekompozíciót használtuk fö eredményünk, a 4.2. Tétel kimondására. A 4.2.2. részben néhány hasonló eredményt ismertettünk, a 4.2.3. szakaszban pedig egy példán keresztül értelmeztük a kapott matematikai formulát. Végül a 4.2.4. szakaszban megmutattuk, hogy a digráfokra javasolt pozíciós erő alapötlete szoros kapcsolatban áll a megadott iteratív felbontással, bár három 
lényeges különbség is felfedezhetö köztük.

A 4.3. alfejezetben a 4.2. Tétel általánosításával foglalkoztunk. Az ellenfelek szerepének a távolsággal arányos exponenciális csökkentése elvezet az általánosított Buchholz módszerhez, ami a 4.3. Tétel alapján lényegében az általánosított sorösszeggel egyezik meg. Az utóbbi eljárás eredetileg más alapokon került bevezetésre, és korábbi gráf interpretációja is eltérő megközelítést alkalmazott. Értelmezésünk kiválóan tükrözi a pontszám és a legkisebb négyzetek módszere közötti átmenetet.

A fejezetben a 4.2. és a 4.3. Tétel jelenti a legfontosabb saját eredményt, de lényegesnek tartjuk az irodalomban ismert módszerekkel történő összevetést is, különösen a pozíciós erő tekintetében. A legkisebb négyzetek esetére vonatkozó állítás már publikálásra került (Csató, 2014a). A levezetésekhez többnyire jól ismert matematikai állításokat használtunk fel, ezek összegyűjtése és megfelelő keretbe rendezése azonban nem kis feladatot jelentett.

Ezen rész elolvasása után számos kérdés merülhet fel. Egyrészt a rendhagyó eset tárgyalása (F.I. Függelék) nem teljes, abban két sejtést fogalmazunk meg. Másrészt a 4.2.2. részben említettük, hogy az $L$ mátrix és $\mathbf{s}$ vektorok helyett azok átlagával, normalizált formájával számoló rekurzív Buchholz eljárás arányos a legkisebb négyzetek módszerével, ezért létezhet hasonló levezetés az általánosított sorösszegre is. Harmadikként a 4.3. alfejezetben bemutatott kiterjesztést említenénk. Az ellenfelek szerepének távolsággal arányos exponenciális csökkentése ugyan kézenfekvő (és szép formulákat eredményező) választás, de más általánosítási lehetőségeket sem zárhatunk ki. Az exponenciális helyett megvalósítható lehet valamilyen hiperbolikus diszkontálás, vagy a figyelembe vett ellenfelek számának korlátozása (David, 1987). Az így adódó módszerek már nem azonosak az általánosított sorösszeggel, de akár axiomatikus szempontból is érdekesnek bizonyulhatnak.

A 3.2. alfejezetben a digráfokat az általunk tárgyalt modellkeretbe illesztettük, ami biztosítja az ezekre javasolt, a csúcsokat rangsoroló módszerek összehasonlítását a vizsgált pontozási eljárásokkal. A 4.2.4. szakasz szerint szoros kapcsolat áll fenn a pozíciós erő (Herings et al., 2005) és a legkisebb négyzetek módszere között: utóbbi az előbbi élek irányításának kiküszöbölésével kapott változatának tekinthető, endogén diszkonttényezővel és eltérő iteratív megközelítéssel. Herings et al. (2005) részletesebb tárgyalás és az 1/a paraméter specifikációja nélkül - súlyozott gráfokra is bevezeti a pozíciós erő fogalmát. Ekkor az $a_{i j}=w_{i j}-w_{j i}$ és $m_{i j}=w_{i j}+w_{j i}$ választással ferdén szimmetrikus eredménymátrixot és szimmetrikus mérkőzésmátrixhoz jutunk, ahol teljesül az $a_{i j} \in\left[-m_{i j}, m_{i j}\right]$ feltétel, azonban a $w_{i i}>0$ által engedélyezett hurokéleket, az egyes objektumok önmagukkal vett összehasonlításait nem tudjuk kezelni. Ez a kapcsolat reményt nyújt az utóbbi lehetőség modellbe építésére.

A fontosabb eredmények publikálása, az általánosított Buchholz módszerrel kapcsolatosak kivételével, lényegében megtörtént (Csató, 2014a). 


\section{5. fejezet}

\section{A pontozási eljárások néhány tulajdonsága}

There is a real need for a thorough study of ranking procedures.

Denis Bouyssou, 2004

A megfelelő pontozási eljárás kiválasztásában segítséget jelenthet a társadalmi választások elméletének (social choice theory) axiomatikus szemlélete (Altman és Tennenholtz, 2005):

- Leíró (descriptive) megközelítés : olyan axiómák, tulajdonságok előírása, melyeket egy adott módszer kielégít, miközben bármely másik legalább egyet megsért közülük. Ez, mint a 2.4. alfejezetben említettük, a kooperatív játékelmélet elosztási koncepciói esetén követett stratégiához hasonlít.

- Normatív (normative) megközelítés : különböző, elméleti szempontból indokoltnak tűnő feltételek, követelmények megfogalmazása, majd annak vizsgálata, melyik eljárás teljesíti ezeket. Kemeny és Snell (1962) három lehetséges esetet említ: (I) az axiómák inkonzisztensek, egyetlen módszer sem elégítheti ki ezek mindegyikét; (II) egyetlen eljárás teljesít minden tulajdonságot, utóbbiak egyértelmüen meghatározzák azt; (III) több módszer is megfelel a feltételeknek. (II) fennállásakor azonban létezik egy negyedik opció, miszerint a megfogalmazott követelmények logikailag nem függetlenek, ugyan egyértelműen karakterizálnak egy eljárást, ehhez azonban elegendő lenne egy valódi részhalmazuk is (Can és Storcken, 2013). Az axiomatikus szemlélet (III) esetén szintén biztosítja a szóba jöhető módszerek körének szükítését.

A következőkben tehát elméletileg vonzó követelményeket fogalmazunk meg, majd megvizsgáljuk, hogy az egyes pontozási eljárások megfelelnek-e ezeknek. Ezáltal 
láthatóvá válnak a köztük levő különbségek és hasonlóságok, bizonyos tulajdonságok előírásával pedig szűkíthető a szóba jöhető módszerek köre. Az első axióma kivételével mindegyiket az aggregált páros összehasonlítási mátrixon alapuló pontozási eljárásokra mondjuk ki.

Az axiómák teljesülését a pontszám, az általánosított sorösszeg, és a legkisebb négyzetek módszerére vizsgáljuk meg. Chebotarev (1994) az általánosított sorösszeggel, míg González-Díaz et al. (2014) az általuk némileg eltérően definiált pontszámmal, a legkisebb négyzetekkel és az általánosított sorösszeggel rögzített $\varepsilon=1 /[m(n-2)]$ mellett foglalkozott. Eredményeikre minden esetben hivatkozni fogunk, és igyekszünk egyértelmüvé tenni saját hozzájárulásunkat. Az újonnan bevezetett axiómákkal kapcsolatos megállapítások mindenképp ilyennek tekinthetők.

5.1. Megjegyzés. Mivel a legkisebb négyzetek módszere csak az összefüggő rangsorolási problémák $\mathcal{R}_{O}$ osztályán egyértelmü, ettől az eljárástól a tulajdonságokat külön jelzés nélkül csak ezen a halmazon követeljük meg.

\subsection{A rangsor változatlanságának megkövetelése}

Először néhány, az objektumok sorrendjének változatlanságát biztosító feltételt ismertetünk.

\subsubsection{Függetlenség az elnevezésektől}

Az első tulajdonság az $R^{(p)}$ egyéni páros összehasonlítási mátrixok átindexelésére vonatkozik: jogos elvárásnak tűnik a pontozási eljárás erre való érzéketlensége.

5.1. Definíció. Anonimitás (anonymity, ANO) (Young, 1974): Legyen $(N, A, M) \in$ $\in \mathcal{R}^{n}$ egy rangsorolási probléma és $\sigma:\{1 ; 2 ; \ldots ; m\} \rightarrow\{1 ; 2 ; \ldots ; m\}$ a szavazók halmazának egy permutációja. Jelölje $\sigma A$ az így kapott eredménymátrixot. Egy $f: \mathcal{R}_{*}^{n} \rightarrow \mathbb{R}^{n}$ általános pontozási eljárás anonim, ha $f_{i}(N, A, M) \geq f_{j}(N, A, M) \Leftrightarrow$ $f_{i}(N, \sigma A, M) \geq f_{j}(N, \sigma A, M)$ minden $X_{i}, X_{j} \in N$-re.

5.1. Lemma. Egy $f: \mathcal{R}^{n} \rightarrow \mathbb{R}^{n}$ pontozási eljárás anonim.

Bizonyítás. Az összeadás kommutativitása miatt az $R$ aggregált páros összehasonlítási mátrix független az $R^{(p)}$ egyéni páros összehasonlítási mátrixok sorrendjétől.

5.2. Lemma. A pontszám, az általánosított sorösszeg, és a legkisebb négyzetek módszere is teljesiti az ANO tulajdonságot.

Bizonyítás. Mindhárom módszer egy pontozási eljárás, így az 5.1. Lemmából adódik. 
A szavazáselméletből ismerős axióma annak megkövetelése, hogy az objektumok értékelése ne függjön azok nevétől, felsorolásuk sorrendjétől.

5.2. Definíció. Semlegesség (neutrality, $N E U$ ) (Young, 1974): Legyen $(N, A, M) \in$ $\in \mathcal{R}^{n}$ egy rangsorolási probléma és $\sigma:\left\{X_{1}, X_{2}, \ldots, X_{n}\right\} \rightarrow\left\{X_{1}, X_{2}, \ldots, X_{n}\right\}$ az objektumok egy permutációja. Jelölje $\sigma(N, A, M) \in \mathcal{R}^{n}$ a permutáció végrehajtásával, az $A$ eredmény- és az $M$ mérkőzésmátrixok sorainak és oszlopainak felcserélésével kapott rangsorolási problémát. Egy $f: \mathcal{R}^{n} \rightarrow \mathbb{R}^{n}$ pontozási eljárás semleges, ha minden $X_{i}, X_{j} \in N$-re $f_{i}(N, A, M) \geq f_{j}(N, A, M) \Leftrightarrow f_{\sigma i}[\sigma(N, A, M)] \geq f_{\sigma j}[\sigma(N, A, M)]$.

A semlegesség számos más cikkben megtalálható, például Rubinstein (1980, Axiom I), Nitzan és Rubinstein (1981, Axiom 1), vagy Chebotarev és Shamis (1999) munkáiban. Néhány helyen, ahol nem jelennek meg az egyes szavazók, ez szerepel anonimitásként (Bouyssou, 1992; Slutzki és Volij, 2005; González-Díaz et al., 2014). Bizonyos esetekben (például González-Díaz et al. (2014)) a változatlanságot csak két objektum kicserélésére követelik meg, noha ez is ekvivalens az 5.2. Definícióval.

5.2. Megjegyzés. Legyen $f: \mathcal{R}^{n} \rightarrow \mathbb{R}^{n}$ egy semleges pontozási eljárás. Ha az $X_{i}, X_{j} \in$ $\in N$ objektumokra $a_{i j}=0$, valamint $a_{i k}=a_{j k}$ és $m_{i k}=m_{j k}$ minden $X_{k} \in N$ esetén, akkor $f_{i}(N, A, M)=f_{j}(N, A, M)$.

Bizonyítás. Lásd Bouyssou (1992, 62. o.).

5.3. Lemma. A pontszám, az általánosított sorösszeg, és a legkisebb négyzetek módszere is teljesíti a NEU tulajdonságot.

Bizonyítás. Lásd González-Díaz et al. (2014, 145. o.). Egyik eljárás sem veszi figyelembe az objektumok elnevezését, csak az $A$ eredmény- és az $M$ mérkőzésmátrixok megfelelő elemeit.

Mind az anonimitás, mind a semlegesség egészen természetes követelménynek tűnik. Utóbbi lehetővé teszi az objektumok számának tetszőleges növelését a rangsor változatlanul hagyása mellett, így egy állításra elegendő az objektumok számában mérve minimális ellenpéldát adni. Ezzel a lehetőséggel magunk is élni fogunk $n=3$ (5.2. Állítás), $n=4$ (5.4. és 6.1. Állítás), $n=5$ (5.9., 5.11. és 5.13. Állítás), vagy $n=8$ (5.1. Tétel) elemmel.

\subsubsection{Technikai összefüggések}

Az alábbi két axióma önmagában nem túl nagy jelentőségü, a későbbiekben viszont hasznosnak bizonyulnak.

5.3. Definíció. Zérusösszegüség (centering, CNT) (Chebotarev, 1994): Legyen $(N, A, M) \in \mathcal{R}^{n}$ egy rangsorolási probléma. Az $f: \mathcal{R}^{n} \rightarrow \mathbb{R}^{n}$ pontozási eljárás zérusösszegü, ha $\sum_{X_{i} \in N} f_{i}(N, A, M)=0$. 
A tulajdonság David (1987, Property 2) cikkében külön elnevezés nélkül szerepel.

5.4. Lemma. A pontszám, az általánosított sorösszeg, és a legkisebb négyzetek módszere is teljesíti a CNT tulajdonságot.

Bizonyitás. A pontszám módszerre az $A$ eredménymátrix ferdén szimmetrikus voltából adódik. Az általánosított sorösszeg módszerre lásd Chebotarev (1994, Property 2). A legkisebb négyzetek módszerére a definícióból adódik $\mathbf{e}^{\top} \mathbf{q}=0$ miatt.

5.4. Definíció. Lineáris kapcsolat az összehasonlítások eredményével (linear relation with comparison results, $L R C R$ ) (Chebotarev, 1994): Legyen $(N, A, M)$, $\left(N, A^{\prime}, M\right),\left(N, A^{\prime \prime}, M\right) \in \mathcal{R}^{n}$ három rangsorolási probléma azonos $N$ objektumhalmazzal és $M$ mérkőzésmátrixszal, ahol $\alpha, \beta \in \mathbb{R}$ és $\mathbf{s}\left(N, A^{\prime \prime}, M\right)=\alpha \mathbf{s}(N, A, M)+$ $+\beta \mathbf{s}\left(N, A^{\prime}, M\right)$. Egy $f: \mathcal{R}^{n} \rightarrow \mathbb{R}^{n}$ pontozási eljárás lineáris kapcsolatban áll az összehasonlítások eredményével, ha $f\left(N, A^{\prime \prime}, M\right)=\alpha f(N, A, M)+\beta f\left(N, A^{\prime}, M\right)$.

5.1. Állítás. A pontszám, az általánosított sorösszeg, és a legkisebb négyzetek módszere is teljesiti az LRCR tulajdonságot.

Bizonyitás. A pontszám módszerre a definícióból következik. Az általánosított sorösszegre lásd Chebotarev (1994, Property 6). Az $\mathbf{x}(\varepsilon)=(1+\varepsilon m n)(I+\varepsilon L)^{-1} \mathbf{s}$ egyenletrendszerből

$$
\begin{aligned}
\mathbf{x}(\varepsilon)\left(N, A^{\prime \prime}, M\right) & =(1+\varepsilon m n)(I+\varepsilon L)^{-1}\left[\alpha \mathbf{s}(N, A, M)+\beta \mathbf{s}\left(N, A^{\prime}, M\right)\right]= \\
& =\alpha \mathbf{x}(\varepsilon)(N, A, M)+\beta \mathbf{x}(\varepsilon)\left(N, A^{\prime}, M\right) .
\end{aligned}
$$

A legkisebb négyzetek módszerénél ugyanez a gondolatmenet alkalmazható.

\subsection{Multiplikatív transzformációk}

Ebben a részben a rangsorolási probléma eredmény- és mérkőzésmátrixainak arányos megváltoztatásaival foglalkozunk.

5.5. Definíció. Homogenitás (homogeneity, HOM) (González-Díaz et al., 2014): Legyen $(N, A, M) \in \mathcal{R}^{n}$ egy rangsorolási probléma és $k>0$, amire $(N, k A, k M) \in$ $\in \mathcal{R}^{n}$. Egy $f: \mathcal{R}^{n} \rightarrow \mathbb{R}^{n}$ pontozási eljárás homogén, ha $f_{i}(N, A, M) \geq f_{j}(N, A, M) \Leftrightarrow$ $f_{i}(N, k A, k M) \geq f_{j}(N, k A, k M)$ minden $X_{i}, X_{j} \in N$-re.

A HOM szerint az objektumok sorrendje invariáns a rangsorolási probléma skálázására. Mivel $m$ darab egyéni páros összehasonlítás mátrixból indultunk ki, az $M$ mérkőzésmátrix elemei egészek, ezért $k>0$ csak olyan lehet, hogy $k M$ elemei is egészek. González-Díaz et al. (2014) nem él ezzel a megszorítással. 
5.5. Lemma. A pontszám, és a legkisebb négyzetek módszere teljesíti a HOM tulajdonságot.

Bizonyítás. Lásd González-Díaz et al. (2014, 145 o.). A pontszám módszernél minden sorelem $k$-szorosára változik, így $\mathbf{s}(N, k A, k M) \propto \mathbf{s}(N, A, M)$. A legkisebb négyzetek módszerénél a megoldandó egyenletrendszerek $L \mathbf{q}(N, A, M)=\mathbf{s}(N, A, M)$ és $\mathbf{e}^{\top} \mathbf{q}(N, A, M)=0$, illetve $k L \mathbf{q}(N, k A, k M)=\mathbf{s}(N, k A, k M)=k \mathbf{s}(N, A, M)$ és $\mathbf{e}^{\top} \mathbf{q}(N, k A, k M)=0$, amiből $\mathbf{q}(N, k A, k M)=\mathbf{q}(N, A, M)$.

Ugyanakkor az általánosított sorösszeg módszernél

$$
\begin{aligned}
\mathbf{x}(\varepsilon)(N, k A, k M) & =(1+\varepsilon m n)(I+k \varepsilon L)^{-1} \mathbf{s}(N, k A, k M)= \\
& =(I+k \varepsilon L)^{-1}(k I+k \varepsilon L) \mathbf{x}(\varepsilon)(N, A, M),
\end{aligned}
$$

vagyis $\mathbf{x}(\varepsilon)(N, k A, k M)$ és $\mathbf{x}(\varepsilon)(N, A, M)$ általában nem arányosak. Ez azt sugallja, hogy az általánosított sorösszeg nem homogén.

5.2. Állítás. Az általánosított sorösszeg módszer rögzített $\varepsilon$ mellett nem teljesíti a HOM tulajdonságot.

Bizonyítás. Elegendő ellenpéldát adni valamilyen $\varepsilon>0$ paraméterre. A példa viszonylag egyszerü, mindössze három objektumból áll, bár az összehasonlítások maximális száma meglehetősen nagy. ${ }^{11}$

5.1. ábra. Az 5.1. Példa rangsorolási problémája

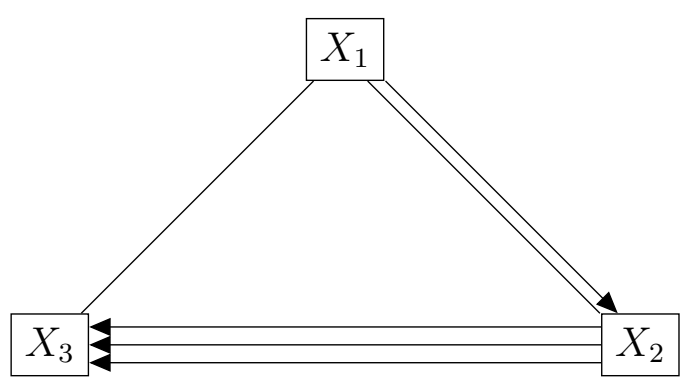

5.1. Példa. Tekintsük az $(N, A, M) \in \mathcal{R}^{3}$ rangsorolási problémát (5.1. ábra), ahol:

$$
A=\left[\begin{array}{ccc}
0 & 1 & 0 \\
-1 & 0 & 3 \\
0 & -3 & 0
\end{array}\right], \quad M=\left[\begin{array}{lll}
0 & 3 & 2 \\
3 & 0 & 5 \\
2 & 5 & 0
\end{array}\right] \quad \text { és } \quad L=\left[\begin{array}{ccc}
5 & -3 & -2 \\
-3 & 8 & -5 \\
-2 & -5 & 7
\end{array}\right]
$$

Legyen $k=2$, így a mérkőzések száma egész marad, $(N, k A, k M) \in \mathcal{R}^{n}$.

${ }^{11}$ Ez jelentősen csökkenthető, ha eltekintünk a $k M \in \mathbb{N}^{n \times n}$ feltételtől. 
Mivel $m=3$ és $n=3$, az $\varepsilon$ paraméter értékének észszerü felső határa $1 / 3$. Ekkor

$$
\begin{gathered}
\mathbf{x}(1 / 3)(N, R, M)=[2 ; 2 ;-4]^{\top}, \text { és } \\
\mathbf{x}(1 / 3)(N, 2 R, 2 M)=[4.5352 ; 3.9437 ;-8.4789]^{\top},
\end{gathered}
$$

$\operatorname{azaz} X_{1} \sim \underset{(N, A, M)}{\stackrel{\mathbf{x}(1 / 3)}{ }} X_{2}$, de $X_{1} \succ \underset{(N, 2 A, 2 M)}{\mathbf{x}(1 / 3)} X_{2}$

Ha megengedjük, hogy $\varepsilon$ függjön a mérkőzések számától, az $M$ mátrixtól, már eltérő eredményt kapunk: az $\bar{\varepsilon}=1 /[m(n-2)]$ észszerü felső határ mellett az általánosított sorösszeg homogén González-Díaz et al. (2014, 145. o.).

5.3. Állítás. Az általánosított sorösszeg módszer teljesíti a HOM tulajdonságot, amennyiben $\varepsilon$ fordítottan arányos $k$-val, azaz $\varepsilon(k)=\varepsilon(1) / k$.

Bizonyítás. Egyszerü átalakításokkal adódik:

$$
\mathbf{x}(\varepsilon(k))(N, k A, k M)=(1+\varepsilon m n)(I+\varepsilon L)^{-1} \mathbf{s}(N, k A, k M)=k \mathbf{x}(\varepsilon(1))(N, A, M) .
$$

5.3. Megjegyzés. Az $\bar{\varepsilon}=1 /[m(n-2)]$ észszerű felső határ fordítottan arányos $k$-val.

1. Sejtés. Az 5.3. Állítás bizonyítása arra utal, hogy az általánosított sorösszeg módszer nem lehet homogén, ha $\varepsilon$ nem fordítottan arányos $k$-val.

Tehát a HOM tulajdonság bevezetése újabb információt ad az $\varepsilon$ paraméter választásáról, célszerü függővé tenni azt a mérkőzésszámtól.

Lehet értelme csak az $A$ eredménymátrix konstansszorosát venni, bár ezt az $M$ mérkőzésmátrixszal együtt kaptuk az $R$ aggregált páros összehasonlítási mátrixból.

5.6. Definíció. Eredmények elfogadható transzformációja (admissible transformation of the results) : Legyen $(N, A, M) \in \mathcal{R}^{n}$ egy rangsorolási probléma. Az eredmények elfogadható transzformációja egy olyan $(N, k A, M) \in \mathcal{R}^{n}$ rangsorolási problémát eredményez, amire $k>0, k \in \mathbb{R}$ és $k a_{i j} \in\left[-m_{i j}, m_{i j}\right]$ minden $X_{i}, X_{j} \in N$ esetén.

A $k$ pozitív szorzó értéke azért nem lehet tetszőleges, hogy megőrizzük a páros összehasonlítások eredményének - az $R$ aggregált páros összehasonlítási mátrix definíciójából adódó - korlátosságát. Ennek megfelelően $0<k \leq 1$ mindig lehetséges.

5.2. Példa. Az 5.1. Példában $\max _{X_{i}, X_{j} \in N} a_{i j} / m_{i j}=\max \{1 / 3 ; 3 / 5\}=3 / 5$, ezért $0<k \leq 5 / 3$ mellett $(N, k A, M) \in \mathcal{R}^{n}$ az eredmények elfogadható transzformációjával kapott rangsorolási probléma. 
5.7. Definíció. Skála invariancia (scale invariance, $S I)$ : Legyen $(N, A, M)$, $(N, k A, M) \in \mathcal{R}^{n}$ két rangsorolási probléma, ahol $(N, k A, M)$ az eredmények elfogadható transzformációjával kapható $(N, A, M)$-ből. Egy $f: \mathcal{R}^{n} \rightarrow \mathbb{R}^{n}$ pontozási eljárás skála invariáns, ha $f_{i}(N, A, M) \geq f_{j}(N, A, M) \Leftrightarrow f_{i}(N, k A, M) \geq f_{j}(N, k A, M)$ minden $X_{i}, X_{j} \in N$-re.

A skála invariancia szerint az objektumok rangsora változatlan, ha a győzelmek $\left(a_{i j}>0\right)$ és a vereségek $\left(a_{i j}<0\right)$ mértékét - a pontozási eljárások értelmezési tartományán, az $\mathcal{R}$ halmazon belül maradva - arányosan módosítjuk.

Ez főleg a gyakorlati alkalmazások szempontjából tűnik fontosnak. Amennyiben a páros összehasonlítások eredménye nem mérhető folytonos, hanem csak diszkrét skálán ${ }^{12}$, akkor nem egyértelmü, hogy ezek miként jeleníthetők meg az $R$ eredménymátrixban. A skála invariancia értelmében ez bizonyos esetekben nem számít: ha például három kimenetel lehetséges, a (győzelem $\Rightarrow r_{i j}=\kappa$; döntetlen $\Rightarrow r_{i j}=0$; vereség $\left.\Rightarrow r_{i j}=-\kappa\right)$ kódolással az objektumok sorrendje független $0<\kappa \leq \min _{X_{i}, X_{j} \in N} m_{i j}$ konkrét értékétől.

5.1. Következmény. Ha egy $f: \mathcal{R}^{n} \rightarrow \mathbb{R}^{n}$ pontozási eljárás kielégíti az LRCR tulajdonságot, akkor az SI-t is teljesiti.

Bizonyítás. Legyen $A^{\prime}=A$ és $A^{\prime \prime}=k A$. Ekkor az $\alpha=k, \beta=0$ választással $A^{\prime \prime}=$ $=\alpha A+\beta A^{\prime}=k A$, így $\mathbf{s}\left(N, A^{\prime \prime}, M\right)=\alpha \mathbf{s}(N, A, M)+\beta \mathbf{s}\left(N, A^{\prime}, M\right)=k \mathbf{s}(N, A, M)$, teljesül az összehasonlítások eredményétől való lineáris függőség feltétele. Vagyis $f\left(N, A^{\prime \prime}, M\right)=k f(N, A, M), f(N, k A, M)$ és $f(N, A, M)$ arányos.

5.4. Megjegyzés. Tekintsük az $R$ aggregált páros összehasonlítási mátrixot, ahol $r_{i j}=\left(a_{i j}+m_{i j}\right) / 2$ minden $X_{i}, X_{j} \in N$-re. Az eredmények elfogadható transzformációjával minden olyan reducibilis $R$ mátrix irreducibilissé tehetö, amihez nem blokk diagonális $M$ mérkőzésmátrix tartozik. Ekkor ugyanis bármely $X_{i} \neq X_{j}$-re létezik olyan $X_{i}=X_{k_{0}}, X_{k_{1}}, \ldots, X_{k_{t}}=X_{j}$ objektumsorozat, hogy $m_{k_{\ell} k_{\ell+1}}>0$ minden $\ell=0,1, \ldots, t-1$-re, ezért például a $k=1 / 2$ választással elérhető $k r_{i j}=\left(k a_{i j}+\right.$ $\left.+m_{i j}\right) / 2>0 \Leftrightarrow m_{i j}>0$, hiszen $m_{i j}>0$ mellett $1 / 2 a_{i j}>-m_{i j}$.

Az 5.4. Megjegyzés nagy jelentőséggel bír, mert - ahogy azt a 3.3.2. szakaszban láttuk - több pontozási eljárás csak az irreducibilis $R$ aggregált páros összehasonlítási mátrixszal rendelkező rangsorolási problémák halmazán ad egyértelmű megoldást. A skála invariancia megkövetelésével ez minden nem blokk diagonális szerkezetü mérkőzésmátrixszal rendelkező rangsorolási problémára igaz lesz, ami a 3.2. Lemma szerint a teljes $\mathcal{R}_{O}$ osztály.

\footnotetext{
12 Vagy kvázi diszkrét skálán: egy labdarúgó mérkőzés eredménye ugyan elvileg tetszőleges lehet, mégis ritka az olyan alkalom, amikor a két csapat együttesen 5-6 gólnál többet rúg.
} 
5.6. Lemma. A pontszám, az általánosított sorösszeg, és a legkisebb négyzetek módszere teljesíti az SI tulajdonságot.

Bizonyítás. Az 5.1. Állításból és az 5.1. Következményből adódik.

A homogenitás másik részleges változatának, amikor az $M$ mérkőzésmátrixot szorozzuk meg egy $k>0$ konstanssal, nincs gyakorlati relevanciája, ráadásul HOM és $S I$ együttes fennállásából egyben ez is következne.

\subsection{Additív transzformációk}

Ebben az alfejezetben rangsorolási problémák összeadhatóságával foglalkozunk.

\subsection{1. Összeadhatóság}

Az alábbi tulajdonság minden esetben megkívánja a rangsorolási problémák és a rangsor additivitását.

5.8. Definíció. Konzisztencia (consistency, $C S$ ) (Young, 1974): Legyen $(N, A, M)$, $\left(N, A^{\prime}, M^{\prime}\right) \in \mathcal{R}^{n}$ két rangsorolási probléma, $X_{i}, X_{j} \in N$ két objektum, és $f$ : $\mathcal{R}^{n} \rightarrow \mathbb{R}^{n}$ egy pontozási eljárás, amire $f_{i}(N, A, M) \geq f_{j}(N, A, M)$ és $f_{i}\left(N, A^{\prime}, M^{\prime}\right) \geq$ $\geq f_{j}\left(N, A^{\prime}, M^{\prime}\right)$. $f$ konzisztens, ha $f_{i}\left(N, A+A^{\prime}, M+M^{\prime}\right) \geq f_{j}\left(N, A+A^{\prime}, M+M^{\prime}\right)$, söt, $f_{i}\left(N, A+A^{\prime}, M+M^{\prime}\right)>f_{j}\left(N, A+A^{\prime}, M+M^{\prime}\right)$, ha $f_{i}(N, A, M)>f_{j}(N, A, M)$ $\operatorname{vagy} f_{i}\left(N, A^{\prime}, M^{\prime}\right)>f_{j}\left(N, A^{\prime}, M^{\prime}\right)$.

A konzisztencia szerint amikor $X_{i}$ egyik rangsorolási problémában sem volt hátrébb $X_{j}$-nél, ez azok összegében sem fordulhat elő. Sőt, amennyiben valamelyikben szigorúan előrébb végzett, akkor az aggregált problémában is. Az additivitáshoz csak azt a minimális követelményt írjuk elő, hogy az $N$ objektumhalmaz azonos legyen, ennek hiányában az összeadás nem értelmezhető művelet.

Young (1974) szavazáselméleti tanulmánya csak a legjobb alternatíva kiválasztásával foglalkozik, pontozási eljárásokra Nitzan és Rubinstein (1981, Axiom 3) fogalmazta meg a konzisztenciát. González-Díaz et al. (2014) egy ennél gyengébb tulajdonságot illet a sorrendtartó (order preservation, $O P$ ) elnevezéssel, mert elöírja a $d_{i} / d_{j}=d_{i}^{\prime} / d_{j}^{\prime}$ minden $X_{i}, X_{j} \in N$-re feltétel teljesülését is.

5.7. Lemma. A pontszám módszer teljesíti a CS tulajdonságot.

Bizonyítás. Lásd Nitzan és Rubinstein (1981, 157. o.). A definíció alapján

$$
s_{i}(N, A, M)=\sum_{X_{k} \in N} a_{i k} \geq \sum_{X_{k} \in N} a_{j k}=s_{j}(N, A, M) \text { és }
$$




$$
s_{i}\left(N, A^{\prime}, M^{\prime}\right)=\sum_{X_{k} \in N} a_{i k}^{\prime} \geq \sum_{X_{k} \in N} a_{j k}^{\prime}=s_{j}\left(N, A^{\prime}, M^{\prime}\right),
$$

melyek összeadásával

$s_{i}\left(N, A+A^{\prime}, M+M^{\prime}\right)=\sum_{X_{k} \in N}\left(a_{i k}+a_{i k}^{\prime}\right) \geq \sum_{X_{k} \in N}\left(a_{j k}+a_{j k}^{\prime}\right)=s_{j}\left(N, A+A^{\prime}, M+M^{\prime}\right)$.

Ha valamelyik feltételben szigorú egyenlőtlenség áll fenn, akkor az összegben is.

5.4. Állítás. Az általánosított sorösszeg, és a legkisebb négyzetek módszere nem teljesíti a CS tulajdonságot.

Bizonyítás. $n=4$ esetén egy példán keresztül bizonyítjuk az állítást.

5.2. ábra. Az 5.3. Példa rangsorolási problémái

(a) $\mathrm{Az}(N, A, M)$ rangsorolási probléma

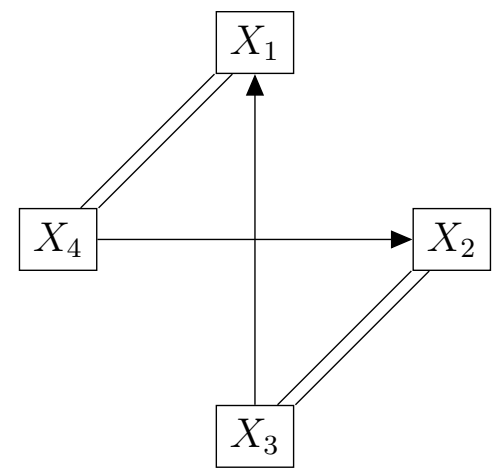

(b) $\mathrm{Az}\left(N, A^{\prime}, M^{\prime}\right)$ rangsorolási probléma

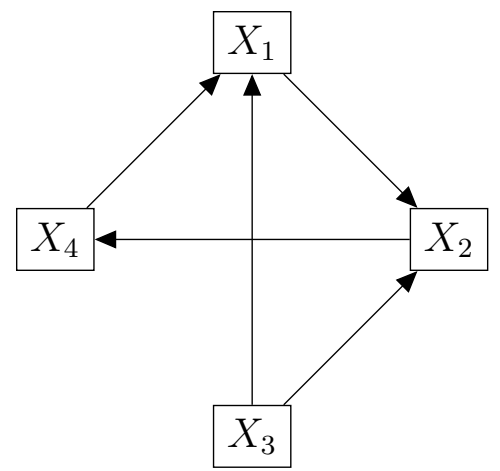

5.3. Példa. Legyen az $(N, A, M) \in \mathcal{R}_{B}^{4}$ kiegyensúlyozott és $\left(N, A^{\prime}, M^{\prime}\right) \in \mathcal{R}^{4}$ rangsorolási problémákra (5.2. ábra):

$$
\begin{array}{cc}
A=\left[\begin{array}{cccc}
0 & 0 & -1 & 0 \\
0 & 0 & 0 & -1 \\
1 & 0 & 0 & 0 \\
0 & 1 & 0 & 0
\end{array}\right], A^{\prime}=\left[\begin{array}{cccc}
0 & 1 & -1 & -1 \\
-1 & 0 & -1 & 1 \\
1 & 1 & 0 & 0 \\
1 & -1 & 0 & 0
\end{array}\right], \quad \text { és } \\
M=\left[\begin{array}{llll}
0 & 0 & 1 & 2 \\
0 & 0 & 2 & 1 \\
1 & 2 & 0 & 0 \\
2 & 1 & 0 & 0
\end{array}\right], \quad M^{\prime}=\left[\begin{array}{llll}
0 & 1 & 1 & 1 \\
1 & 0 & 1 & 1 \\
1 & 1 & 0 & 0 \\
1 & 1 & 0 & 0
\end{array}\right] .
\end{array}
$$

Legyen $\left(N, A^{\prime \prime}, M^{\prime \prime}\right)=\left(N, A+A^{\prime}, M+M^{\prime}\right) \in \mathcal{R}^{4}$, azaz $A^{\prime \prime}=A+A^{\prime}$ és $M^{\prime \prime}=M+M^{\prime}$.

Legyenek az egyes rangsorolási problémákhoz tartozó, a pontszám, az általánosított sorösszeg, és a legkisebb négyzetek módszerével kapott értékelővektorok sorrendben $\mathbf{s}, \mathbf{x}(\varepsilon)$ és $\mathbf{q} ; \mathbf{s}^{\prime}, \mathbf{x}^{\prime}(\varepsilon)$ és $\mathbf{q}^{\prime} ; \mathbf{s}^{\prime \prime}, \mathbf{x}^{\prime \prime}(\varepsilon)$ és $\mathbf{q}^{\prime \prime}$. 
Tehát $n=4, m=m^{\prime}=1, \mathbf{s}=[-1,-1,1,1]^{\top}$ és $\mathbf{s}^{\prime}=[-1,-1,2,0]^{\top}$, azaz $m^{\prime \prime}=m+m^{\prime}=2, \mathbf{s}^{\prime \prime}=\mathbf{s}+\mathbf{s}^{\prime}=[-2,-2,3,1]^{\top}$, valamint

$$
I+\varepsilon L=\left[\begin{array}{cccc}
1+3 \varepsilon & 0 & -\varepsilon & -2 \varepsilon \\
0 & 1+3 \varepsilon & -2 \varepsilon & -\varepsilon \\
-\varepsilon & -2 \varepsilon & 1+3 \varepsilon & 0 \\
-2 \varepsilon & -\varepsilon & 0 & 1+3 \varepsilon
\end{array}\right], I+\varepsilon L^{\prime}=\left[\begin{array}{cccc}
1+3 \varepsilon & -\varepsilon & -\varepsilon & -\varepsilon \\
-\varepsilon & 1+3 \varepsilon & -\varepsilon & -\varepsilon \\
-\varepsilon & -\varepsilon & 1+2 \varepsilon & 0 \\
-\varepsilon & -\varepsilon & 0 & 1+2 \varepsilon
\end{array}\right] .
$$

$I+\varepsilon\left(L+L^{\prime}\right)$ ezzel analóg módon írható fel. Az $\mathbf{x}(\varepsilon)=(1+\varepsilon m n)(I+\varepsilon L)^{-1} \mathbf{s}$ egyenletek alapján

$$
\begin{gathered}
x_{1}(\varepsilon)=x_{2}(\varepsilon)=(1+\varepsilon m n) \frac{-\left(1+6 \varepsilon+8 \varepsilon^{2}\right)}{1+12 \varepsilon+44 \varepsilon^{2}+48 \varepsilon^{3}}=-\frac{1+10 \varepsilon+32 \varepsilon^{2}+32 \varepsilon^{3}}{1+12 \varepsilon+44 \varepsilon^{2}+48 \varepsilon^{3}}, \text { és } \\
x_{1}^{\prime}(\varepsilon)=x_{2}^{\prime}(\varepsilon)=\left(1+\varepsilon m^{\prime} n\right) \frac{-1}{1+4 \varepsilon}=-1 ; \mathrm{de} \\
x_{1}^{\prime \prime}(\varepsilon)-x_{2}^{\prime \prime}(\varepsilon)=\left(1+\varepsilon m^{\prime \prime} n\right) \frac{-\left(2 \varepsilon+20 \varepsilon^{2}\right)}{1+22 \varepsilon+154 \varepsilon^{2}+340 \varepsilon^{3}}=-\frac{2 \varepsilon+36 \varepsilon^{2}+160 \varepsilon^{3}}{1+22 \varepsilon+154 \varepsilon^{2}+340 \varepsilon^{3}}<0 .
\end{gathered}
$$

Vagyis $X_{1} \sim \underset{(N, A, M)}{\mathbf{x}(\varepsilon)} X_{2}$ és $X_{1} \sim \underset{\left(N, A^{\prime}, M\right)}{\mathbf{x}(\varepsilon)} X_{2}$, azonban $X_{1} \prec \underset{\left(N, A^{\prime \prime}, M^{\prime \prime}\right)}{\mathbf{x}(\varepsilon)} X_{2}$, így az általánosított sorösszeg egyetlen $\varepsilon$ paraméterre sem konzisztens.

A példát a legkisebb négyzetek módszerével kiszámolva, a 3.3. Állítás értelmében

$$
\begin{gathered}
q_{1}=\frac{\lim _{\varepsilon \rightarrow \infty} x_{1}(\varepsilon)}{m n}=q_{2}=\frac{\lim _{\varepsilon \rightarrow \infty} x_{2}(\varepsilon)}{m n}=-\frac{23}{48} \cdot \frac{1}{4}=-\frac{1}{6}, \text { és } \\
q_{1}^{\prime}=\frac{\lim _{\varepsilon \rightarrow \infty} x_{1}(\varepsilon)^{\prime}}{m n}=q_{2}^{\prime}=\frac{\lim _{\varepsilon \rightarrow \infty} x_{2}(\varepsilon)^{\prime}}{m n}=-\frac{1}{4} ; \text { de } \\
q_{1}^{\prime \prime}-q_{2}^{\prime \prime}=\frac{\lim _{\varepsilon \rightarrow \infty}\left[x_{1}(\varepsilon)-x_{2}(\varepsilon)\right]}{m n}=-\frac{80}{340} \cdot \frac{1}{4}=-\frac{1}{17}<0 .
\end{gathered}
$$

Tehát $X_{1} \sim{ }_{(N, A, M)}^{\mathbf{q}} X_{2}$ és $X_{1} \sim{\underset{\left(N, A^{\prime}, M^{\prime}\right)}{\mathbf{q}}}_{2}$, azonban $X_{1} \prec \underset{\left(N, A^{\prime \prime}, M^{\prime \prime}\right)}{\mathbf{q}} X_{2}$, ezért a legkisebb négyzetek módszere sem konzisztens.

5.5. Megjegyzés. A konkrét $\varepsilon=1 / 3$ értékre az 5.1. Példa is elegendő lenne, hiszen $k=2$ esetén a homogenitás a konzisztenciánál gyengébb követelmény, mert ott $A^{\prime}=$ $=A$ és $M^{\prime}=M$, de már az előbbi sem teljesül. A legkisebb négyzetek módszerénél szintén létezik ellenpélda $n=3$ esetén.

5.6. Megjegyzés. González-Díaz et al. (2014, Example 4.2) egy ennél gyengébb axióma (a már említett $O P$ ) megsértését látta be a legkisebb négyzetek módszerére és az általánosított sorösszegre rögzített $\varepsilon=1 /[m(n-2)]$ mellett.

5.7. Megjegyzés. Az 5.2. Példában a $C S$ tulajdonság megsértésénél több is teljesül, mert $x_{1}(\varepsilon)(N, A, M)=x_{2}(\varepsilon)(N, A, M)$ és $x_{1}(\varepsilon)\left(N, A^{\prime}, M^{\prime}\right)=x_{2}(\varepsilon)\left(N, A^{\prime}, M^{\prime}\right)$ miatt az sem elegendő megszorítás, ha a vizsgált objektumok értékelése megegyezik a két összeadandó rangsorolási problémában. Csató (2014b) ezt a tulajdonságot azonosságtartásként (equality preservation, EP) definiálja. 


\subsubsection{Az összeadhatóság finomítása}

Az alábbi tulajdonság jelentős mértékben gyengíti a $C S$ axiómát.

5.9. Definíció. Egyenlőségtartás (flatness preservation, FP) (Slutzki és Volij, 2005): Legyen $(N, A, M),\left(N, A^{\prime}, M^{\prime}\right) \in \mathcal{R}^{n}$ két rangsorolási probléma és $f: \mathcal{R}^{n} \rightarrow \mathbb{R}^{n}$ egy pontozási eljárás, amire $f_{i}(N, A, M)=f_{j}(N, A, M)$ és $f_{i}\left(N, A^{\prime}, M^{\prime}\right)=f_{j}\left(N, A^{\prime}, M^{\prime}\right)$ minden $X_{i}, X_{j} \in N$ esetén. $f$ egyenlöségtartó, ha $f_{i}\left(N, A+A^{\prime}, M+M^{\prime}\right)=f_{j}(N, A+$ $\left.+A^{\prime}, M+M^{\prime}\right)$ minden $X_{i}, X_{j} \in N$-re.

Az FP tulajdonság értelmében két olyan rangsorolási problémát összeadva, melyekben a pontozási eljárás nem tesz különbséget az objektumok között, ez az aggregált rangsorolási problémára is igaz lesz. Ha az egyenlőségre vonatkozó feltételt csak a vizsgált $X_{i}$ és $X_{j}$ objektumok vonatkozásában követelnénk meg, azt az 5.6. Megjegyzés szerint az általánosított sorösszeg és a legkisebb négyzetek módszere még nem elégítené ki.

5.2. Következmény. Ha egy $f: \mathcal{R}^{n} \rightarrow \mathbb{R}^{n}$ pontozási eljárás kielégíti a $C S$ tulajdonságot, akkor az FP-t is teljesiti.

5.8. Lemma. A pontszám, az általánosított sorösszeg, és a legkisebb négyzetek módszere is teljesíti az FP tulajdonságot.

Bizonyítás. Az állítást González-Díaz et al. (2014, Corollary 4.3) mutatta meg a legkisebb négyzetek módszerére, González-Díaz et al. (2014, Proposition 4.2) pedig a rögzített $\varepsilon=1 /[m(n-2)]$ paraméterü általánosított sorösszeg eljárásra.

A pontszám módszerre az 5.7. Lemmából és az 5.2. Következményből adódik.

Mivel a pontszám zérusösszegü, ha $s_{i}(N, A, M)=s_{j}(N, A, M)$ minden $X_{i}, X_{j} \in$ $\in N$-re, akkor $\mathbf{s}(N, A, M)=\mathbf{0}$. Emiatt $\mathbf{x}(\varepsilon)(N, A, M)=(1+\varepsilon m n)(I+\varepsilon L)^{-1} \mathbf{0}=\mathbf{0}$. Megfordítva, ha $\mathbf{x}(\varepsilon)(N, A, M)=\mathbf{0}$, akkor $(1+\varepsilon m n) \mathbf{s}=\mathbf{0}$, így $\mathbf{s}(N, A, M)=\mathbf{0}$. Tehát $\mathbf{s}(N, A, M)=\mathbf{0} \Leftrightarrow \mathbf{x}(\varepsilon)(N, A, M)=\mathbf{0}$, amiből már következik, hogy az általánosított sorösszeg is egyenlőségtartó.

A legkisebb négyzetek módszerénél ugyanez a gondolatmenet alkalmazható.

A konzisztencia meglehetősen erős feltételének más irányú enyhítése az alábbi.

5.10. Definíció. Eredmény konzisztencia (result consistency, RCS): Legyen $(N, A, M),\left(N, A^{\prime}, M^{\prime}\right) \in \mathcal{R}^{n}$ két rangsorolási probléma, $X_{i}, X_{j} \in N$ két objektum, és $f: \mathcal{R}^{n} \rightarrow \mathbb{R}^{n}$ egy pontozási eljárás, hogy $f_{i}(N, A, M) \geq f_{j}(N, A, M)$ és $f_{i}\left(N, A^{\prime}, M\right) \geq f_{j}\left(N, A^{\prime}, M\right)$. $f$ eredmény konzisztens, ha $f_{i}\left(N, A+A^{\prime}, 2 M\right) \geq$ $\geq f_{j}\left(N, A+A^{\prime}, 2 M\right)$, söt, $f_{i}\left(N, A+A^{\prime}, 2 M\right)>f_{j}\left(N, A+A^{\prime}, 2 M\right)$, ha $f_{i}(N, A, M)>$ $>f_{j}(N, A, M)$ vagy $f_{i}\left(N, A^{\prime}, M\right)>f_{j}\left(N, A^{\prime}, M\right)$. 
Tehát a konzisztenciával szemben csak akkor követeljük meg a sorrend additivitástól való függetlenségét, ha az összeadott rangsorolási problémák $N$ objektumhalmaza mellett az $M$ mérkőzésmátrixok is azonosak.

5.3. Következmény. Ha egy $f: \mathcal{R}^{n} \rightarrow \mathbb{R}^{n}$ pontozási eljárás kielégíti a $C S$ tulajdonságot, akkor az RCS-t is teljesíti.

5.4. Következmény. Ha egy $f: \mathcal{R}^{n} \rightarrow \mathbb{R}^{n}$ pontozási eljárás kielégíti az $R C S$ (vagy a CS) tulajdonságot, akkor pozitív egész k-kra a HOM-ot is teljesíti.

5.9. Lemma. A pontszám módszer teljesiti az RCS tulajdonságot.

Bizonyítás. Az 5.7. Lemmából és az 5.3. Következményből adódik.

5.5. Állítás. A legkisebb négyzetek módszere teljesíti az RCS tulajdonságot.

Bizonyítás. Megmutatjuk, hogy $2 \mathbf{q}\left(N, A+A^{\prime}, M+M\right)=\mathbf{q}(N, A, M)+\mathbf{q}\left(N, A^{\prime}, M\right)$. Ha az $M$ mérkőzésmátrixhoz tartozó $G$ összehasonlítási multigráf Laplace-mátrixa $L$, akkor az $M+M$ mérkőzésmátrixhoz tartozó $2 L$, ezért

$$
\begin{aligned}
2 L \mathbf{q}\left(N, A+A^{\prime}, M+M\right) & =L\left[\mathbf{q}(N, A, M)+\mathbf{q}\left(N, A^{\prime}, M\right)\right]= \\
& =\mathbf{s}(N, A, M)+\mathbf{s}\left(N, A^{\prime}, M\right)=\mathbf{s}\left(N, A+A^{\prime}, M+M\right)
\end{aligned}
$$

illetve $\mathbf{e}^{\top} \mathbf{q}\left(N, A+A^{\prime}, M+M\right)=\mathbf{e}^{\top}\left[(1 / 2) \mathbf{q}(N, A, M)+(1 / 2) \mathbf{q}\left(N, A^{\prime}, M\right)\right]=0$.

5.10. Lemma. Az általánosított sorösszeg módszer rögzített $\varepsilon$ mellett nem teljesíti az RCS tulajdonságot.

Bizonyítás. Az 5.1. Példában $k=2$, így alkalmazható az 5.4. Következmény.

5.6. Állítás. Az általánosított sorösszeg módszer teljesíti az RCS tulajdonságot, amennyiben $\varepsilon$ fordítottan arányos az összeadott rangsorolási problémák számával.

Bizonyítás. Legyen $\mathbf{x}(\varepsilon)=\mathbf{x}(\varepsilon)(N, A, M), \mathbf{x}(\varepsilon)^{\prime}=\mathbf{x}(\varepsilon)\left(N, A^{\prime}, M\right)$ és $\mathbf{x}(\varepsilon)^{\prime \prime}=$ $=\mathbf{x}(\varepsilon)\left(N, A+A^{\prime}, M+M\right)$. Egyszerü átalakításokkal adódik:

$$
\begin{aligned}
\mathbf{x}(\varepsilon / 2)^{\prime \prime} & =(1+\varepsilon m n)(I+\varepsilon L)^{-1} \mathbf{s}\left(N, A+A^{\prime}, M+M\right)= \\
& =(1+\varepsilon m n)(I+\varepsilon L)^{-1}\left[\mathbf{s}(N, A, M)+\mathbf{s}\left(N, A^{\prime}, M\right)\right]=\mathbf{x}(\varepsilon)+\mathbf{x}(\varepsilon)^{\prime}
\end{aligned}
$$

5.8. Megjegyzés. Az $\bar{\varepsilon}=1 /[m(n-2)]$ észszerü felső határ fordítottan arányos az összeadott rangsorolási problémák számával. 
2. Sejtés. Az 5.6. Állítás bizonyítása arra utal, hogy az általánosított sorösszeg módszer nem lehet eredmény konzisztens, ha $\varepsilon$ nem fordítottan arányos az összeadott rangsorolási problémák számával.

Az RCS axióma vizsgálata - a HOM tulajdonsághoz hasonlóan - ismét megmutatja, hogy az $\varepsilon$ paramétert célszerü függővé tenni a mérkőzésszámtól.

\subsection{Az eredménymátrix és a rangsorok kapcsolata}

Ebben a szakaszban tovább elemezzük a rangsorolási probléma módosításainak a sorrendre gyakorolt hatását.

\subsubsection{Eredmények megfordítása}

A következő két axióma változatlan $M$ mérkőzésmátrix mellett az $A$ eredménymátrixból vezet le bizonyos tulajdonságokat.

5.11. Definíció. Szimmetria (symmetry, $S Y M$ ) (González-Díaz et al., 2014): ${ }^{13}$ Egy $f: \mathcal{R}^{n} \rightarrow \mathbb{R}^{n}$ pontozási eljárás szimmetrikus, ha $f_{i}(N, O, M)=f_{j}(N, O, M)$ minden $X_{i}, X_{j} \in N$-re.

A szimmetria nem feltétlenül jelenti azt, hogy minden egyéni $R^{(p)}$ páros összehasonlítási mátrixban az összes páros összehasonlítás kimenetele döntetlen lenne, elegendő, ha minden objektum ugyanannyi, azonos intenzitású győzelemmel és vereséggel rendelkezik. Így az sem szükséges, hogy az objektumok mérkőzéseinek $d_{i}$ száma egyenlő legyen. Az SYM értelmében egy egymást kioltó eredményekkel jellemezhető bajnokságban nem lehet különbséget tenni az alternatívák teljesítménye között.

Az axiómát Young (1974), illetve Nitzan és Rubinstein (1981, Axiom 4) törlés (cancellation) néven említi, azonban kizárólag a körmérkőzéses rangsorolási problémák körében, ahol $d_{i}=d_{j}$ minden $X_{i}, X_{j} \in N$ objektumra. Ez indokolja a szimmetria elnevezés megtartását, hiszen itt egy sokkal általánosabb feltételről van szó, ami az $\mathcal{R}_{R}$ halmazon történetesen egybeesik a törléssel.

5.11. Lemma. A pontszám, az általánosított sorösszeg, és a legkisebb négyzetek módszere is teljesíti az SYM tulajdonságot.

Bizonyítás. Lásd González-Díaz et al. (2014, 145 o.). Nyilvánvalóan s $(N, O, M)=$ $=\mathbf{0}$. Továbbá $\mathbf{x}(\varepsilon)=(1+\varepsilon m n)(I+\varepsilon L)^{-1} \mathbf{s}=\mathbf{0}$, míg az $L \mathbf{q}=\mathbf{s}=\mathbf{0}$ és $\mathbf{e}^{\top} \mathbf{q}=\mathbf{0}$ egyenletrendszernek $\mathbf{q}=\mathbf{0}$ biztosan megoldása.

13 A játékelméletből ismerős szimmetria ott jellemzően két hasonló helyzetű játékosra, nem pedig játékokra vonatkozik. Ennek ellenére megtartottuk González-Díaz et al. (2014) elnevezését. 
5.12. Definíció. Megfordíthatóság (inversion, $I N V$ ) (Chebotarev és Shamis, 1998a): Legyen $(N, A, M) \in \mathcal{R}^{n}$ egy rangsorolási probléma. Egy $f: \mathcal{R}^{n} \rightarrow \mathbb{R}^{n}$ pontozási eljárás megfordítható, ha $f_{i}(N, A, M) \geq f_{j}(N, A, M) \Leftrightarrow f_{i}(N,-A, M) \leq f_{j}(N,-$ $-A, M)$ minden $X_{i}, X_{j} \in N$-re.

Az $I N V$ szerint az összehasonlítások eredményének ellenkezőjére változtatása megfordítja az objektumok rangsorát is.

Megfordítható pontozási eljárás alkalmazása esetén az eredmények ellentétesre változása a rangsor ennek megfelelő módosulásához vezet, ami a győzelmek és vereségek azonos kezelését jelenti. González-Díaz et al. (2014) csak az $f_{i}(N, A, M) \geq$ $\geq f_{j}(N, A, M) \Leftrightarrow f_{i}(N,-A, M) \leq f_{j}(N,-A, M)$ feltétel fennállását követeli meg, nekünk azonban ez nem lesz elegendő. Chebotarev (1994, Property 7) általánosított sorösszegre vonatkozó hasonló követelménye transzponálhatóság (transposability) néven szerepel.

5.9. Megjegyzés. Ha egy $f: \mathcal{R}^{n} \rightarrow \mathbb{R}^{n}$ pontozási eljárás kielégíti az $I N V$ tulajdonságot, akkor $f_{i}(N, A, M)>f_{j}(N, A, M) \Leftrightarrow f_{i}(N,-A, M)<f_{j}(N,-A, M)$ minden $X_{i}, X_{j} \in N$-re.

Bizonyítás. Indirekt módon feltehető $f_{i}(N,-A, M) \geq f_{j}(N,-A, M)$, amiből az $I N V$ miatt $f_{i}(N, A, M) \leq f_{j}(N, A, M)$, ez viszont ellentmondás.

5.5. Következmény. Ha egy $f: \mathcal{R}^{n} \rightarrow \mathbb{R}^{n}$ pontozási eljárás kielégíti az INV tulajdonságot, akkor az SYM-et is teljesíti.

Bizonyítás. Lásd González-Díaz et al. (2014, 150. o.). Mivel $O=-O, f_{i}(N, O, M) \geq$ $\geq f_{j}(N, O, M) \Leftrightarrow f_{i}(N, O, M) \leq f_{j}(N, O, M)$, azaz $f_{i}(N, O, M)=f_{j}(N, O, M)$ minden $X_{i}, X_{j} \in N$-re.

5.7. Állítás. Ha egy $f: \mathcal{R}^{n} \rightarrow \mathbb{R}^{n}$ pontozási eljárás kielégíti az $R C S$ (vagy a $C S$ ) és az SYM tulajdonságokat, akkor az INV-et is teljesíti.

Bizonyítás. Indirekt módon tegyük fel, hogy valamilyen $X_{i}, X_{j} \in N$-re $f_{i}(N, A, M) \geq$ $\geq f_{j}(N, A, M)$ és $f_{i}(N,-A, M)>f_{j}(N,-A, M)$. Az eredmény konzisztenciából $A+$ $+(-A)=O$ miatt $f_{i}(N, O, M)>f_{j}(N, O, M)$, ami ellentmond a szimmetriának.

Nitzan és Rubinstein (1981, Lemma 1) körmérkőzéses rangsorolási problémákra bizonyítja, hogy a konzisztenciából és a szimmetriából következik a megfordíthatóság.

5.12. Lemma. A pontszám módszer teljesíti az INV tulajdonságot.

Bizonyítás. Az 5.7. és az 5.11. Lemmából az 5.7. Állítás alapján adódik.

5.8. Állítás. Ha egy $f: \mathcal{R}^{n} \rightarrow \mathbb{R}^{n}$ pontozási eljárás kielégíti az LRCR és az $S Y M$ tulajdonságokat, akkor az INV-et is teljesíti. Ha fennáll a CNT tulajdonság, akkor $f_{i}(N,-A, M)=-f_{i}(N, A, M)$ minden $X_{i} \in N$ és $(N, A, M) \in \mathcal{R}^{n}$ esetén. 
Bizonyítás. Induljunk ki az összehasonlítások eredményétől való lineáris függőségből. Legyen $A^{\prime}=-A$ és $\alpha=\beta=1$, így az 5.11. Lemma értelmében $\mathbf{s}(N, O, M)=$ $=\mathbf{s}(N, A, M)+\mathbf{s}\left(N, A^{\prime}, M\right)=\mathbf{0}$. Ekkor az $L R C R$ alapján $f(N, O, M)=f(N, A, M)+$ $+f(N,-A, M)$, míg a szimmetria miatt $f_{i}(N, O, M)=f_{j}(N, O, M)$, vagyis minden $X_{i}, X_{j} \in N$-re $f_{i}(N, A, M) \geq f_{j}(N, A, M) \Leftrightarrow f_{i}(N,-A, M) \leq f_{j}(N,-A, M)$.

Ha $f$ zérusösszegü is, akkor $\sum_{X_{i} \in N} f_{i}(N, O, M)=0$, tehát a szimmetriából $f_{i}(N, A, M)+f_{i}(N,-A, M)=f_{i}(N, O, M)=0$ minden $X_{i} \in N$-re.

David (1987, Property 1) ugyanezt a tulajdonságot említi az általa javasolt pontozási eljárással kapcsolatban.

5.13. Lemma. Az általánosított sorösszeg és a legkisebb négyzetek módszere is teljesiti az INV tulajdonságot. Söt, az értékelések elöjele éppen az ellenkezöje lesz, miközben abszolútértékük változatlan.

Bizonyítás. Az általánosított sorösszegre lásd Chebotarev (1994, Property 7). Az 5.1. Állításból és az 5.11. Lemmából az 5.8. Állítás alapján adódik. Az értékelések fordított előjeléhez szükség van az 5.4. Lemmára is.

Az előzőek értelmében González-Díaz et al. (2014, Proposition 4.6) az 5.13. Lemmánál gyengébb állítást bizonyít.

A megfordíthatóság első ránézésre kívánatos tulajdonságnak tünik, azonban több olyan győzelem-vereség kombináló pontozási eljárás létezik, melyekre nem igaz, hogy az összes eredmény ellenkezőjére változtatásával a rangsor teljesen megfordul. Ilyen például a fair bets, a pozíciós erő vagy a PageRank módszer. ${ }^{14}$ A kérdést részletesen tárgyalja Csató (2013d).

\subsubsection{Kapcsolat a lineáris rendezéssel}

A következőkben a pontozási eljárásokat próbáljuk meg összekötni egy diszkrét optimalizálási problémaként történő felírással (Kemeny, 1959; Slater, 1961).

5.13. Definíció. Objektumok lineáris rendezésének létezése (existence of a linear order of the objects): Legyen $(N, A, M) \in \mathcal{R}^{n}$ egy rangsorolási probléma. Ebben létezik az objektumok lineáris rendezése, ha

$$
\min _{L \in \mathcal{L}^{n}} \sum_{X_{i}, X_{j} \in N}\left(r_{i j}: X_{i} \prec X_{j}\right)=\min _{L \in \mathcal{L}^{n}} \sum_{X_{i}, X_{j} \in N}\left(0,5 a_{i j}+0,5 m_{i j}: X_{i} \prec X_{j}\right)=0 .
$$

14 Bár az értekezésben nem foglalkoztunk vele, a páros összehasonlítás mátrixok értékelővektorának meghatározására szolgáló Saaty-féle sajátvektor módszer sem megfordítható. Ennek oka - a fair bets eljáráshoz hasonlóan -, hogy a jobb és baloldali sajátvektorok rangsorai nem feltétlenül egymás ellentettjei (Dodd et al., 1995). 
Modellünkben ez csak akkor történhet meg, ha az ismert összehasonlítások maximális mértéküek, azaz $a_{i j} \in\left\{-m_{i j} ; m_{i j}\right\}$. A már több példában használt irányított gráf interpretációban ez azt jelenti, hogy nincsenek irányított körök.

5.4. Példa. A 3.1. Példában az objektumoknak több lineáris rendezése létezik, az ezekben megkövetelt feltételek $X_{1} \succ X_{3} \succ X_{5} \succ X_{7} \succ X_{6}$ és $X_{2} \succ X_{4} \succ X_{6}$.

Ehhez kapcsolódik az alábbi, természetesnek tűnő tulajdonság.

5.14. Definíció. Lineáris rendezés megőrzése (linear order preservation, LOP): Legyen $(N, A, M) \in \mathcal{R}^{n}$ egy rangsorolási probléma, melyben létezik az objektumok $L \in \mathcal{L}^{n}$ lineáris rendezése. Egy $f: \mathcal{R}^{n} \rightarrow \mathbb{R}^{n}$ pontozási eljárás megörzi a lineáris rendezést, ha $X_{i} \succ_{(N, A, M)}^{L} X_{j} \Rightarrow f_{i}(N, A, M) \geq f_{j}(N, A, M)$.

Az LOP axióma elvárja, hogy az objektumok közötti lineáris rendezés létezése esetén a pontozási eljárás egy ilyen sorrendet adjon. A 3.3.2. szakasz alapján az irreducibilis $R$ aggregált páros összehasonlítási mátrixok halmazán egyértelmü megoldást eredményező pontozási eljárások (például fair bets, maximum likelihood) ott bemutatott Zermelo (1929)-féle kiterjesztése megörzi a lineáris rendezést.

Ugyanakkor a lineáris rendezéssel való egyezés csak akkor jogos elvárás, ha az ismeretlen összehasonlításokat, a jövőbeli eredményeket előre meghatározzák a már ismert, múltbeli páros összehasonlítások, azok kimenetele nem függ a véletlentől. ${ }^{15}$

5.9. Állítás. A pontszám módszer és az általánosított sorösszeg módszer nem teljesíti az LOP tulajdonságot.

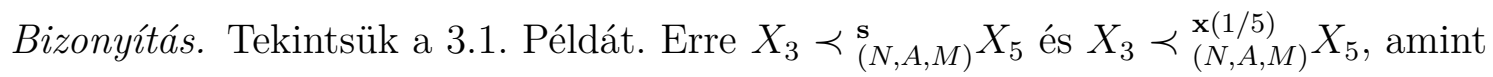
az a 3.1. ábrán látható.

Létezik ennél kisebb méretű ellenpélda is, $n=5$ mellett.

5.5. Példa. Tekintsük az $(N, A, M) \in \mathcal{R}_{U}^{5}$ súlyozatlan rangsorolási problémát (5.3. ábra), ahol:

$$
A=\left[\begin{array}{ccccc}
0 & 1 & 0 & 0 & 0 \\
-1 & 0 & 1 & 1 & 1 \\
0 & -1 & 0 & 0 & 0 \\
0 & -1 & 0 & 0 & 0 \\
0 & -1 & 0 & 0 & 0
\end{array}\right] \quad \text { és } \quad M=\left[\begin{array}{lllll}
0 & 1 & 0 & 0 & 0 \\
1 & 0 & 1 & 1 & 1 \\
0 & 1 & 0 & 0 & 0 \\
0 & 1 & 0 & 0 & 0 \\
0 & 1 & 0 & 0 & 0
\end{array}\right]
$$

A lineáris rendezésekben elöírt feltételek $X_{1} \succ X_{2}$ és $X_{2} \succ X_{i}, i=3,4,5$.

A pontszám módszer értékelővektora $\mathbf{s}(N, A, M)=[1,2,-1,-1,-1]^{\top}$, míg $\mathbf{x}(1 / 6)(N, A, M)=[13 / 7,2,-9 / 7,-9 / 7,-9 / 7]^{\top}$, tehát $X_{1} \prec \underset{(N, A, M)}{\mathbf{s}} X_{2}$ és $X_{1} \prec$ $\prec \underset{(N, A, M)}{\mathbf{x}(1 / 6)} X_{2}$. 
5.3. ábra. Az 5.5. Példa rangsorolási problémája

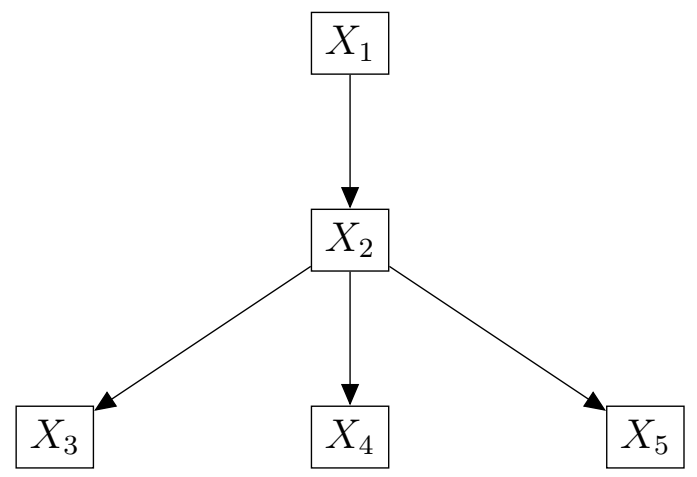

5.1. Tétel. (Rónyai Lajossal közösen) A legkisebb négyzetek módszere nem teljesíti az LOP tulajdonságot.

Bizonyítás. Ellenpéldát adunk $n=8$-ra.

5.6. Példa. Tekintsük az $(N, A, M) \in \mathcal{R}_{B}^{8} \cap \mathcal{R}_{U}^{8}$ kiegyensúlyozott és súlyozatlan rangsorolási problémát (5.4. ábra), ahol:

$$
A=\left[\begin{array}{cccccccc}
0 & 1 & 0 & 0 & 0 & 1 & 1 & 1 \\
-1 & 0 & 1 & 1 & 1 & 0 & 0 & 0 \\
0 & -1 & 0 & 0 & 0 & 1 & 1 & 1 \\
0 & -1 & 0 & 0 & 0 & 1 & 1 & 1 \\
0 & -1 & 0 & 0 & 0 & 1 & 1 & 1 \\
-1 & 0 & -1 & -1 & -1 & 0 & 0 & 0 \\
-1 & 0 & -1 & -1 & -1 & 0 & 0 & 0 \\
-1 & 0 & -1 & -1 & -1 & 0 & 0 & 0
\end{array}\right] \quad \text { és } \quad M=\left[\begin{array}{cccccccc}
0 & 1 & 0 & 0 & 0 & 1 & 1 & 1 \\
1 & 0 & 1 & 1 & 1 & 0 & 0 & 0 \\
0 & 1 & 0 & 0 & 0 & 1 & 1 & 1 \\
0 & 1 & 0 & 0 & 0 & 1 & 1 & 1 \\
0 & 1 & 0 & 0 & 0 & 1 & 1 & 1 \\
1 & 0 & 1 & 1 & 1 & 0 & 0 & 0 \\
1 & 0 & 1 & 1 & 1 & 0 & 0 & 0 \\
1 & 0 & 1 & 1 & 1 & 0 & 0 & 0
\end{array}\right] .
$$

A lineáris rendezésekben megkövetelt feltételek $X_{1} \succ X_{2}, X_{2} \succ X_{i}, i=3,4,5$ és $X_{i} \succ X_{j}, i=3,4,5, j=6,7,8$.

A legkisebb négyzetek módszerével kapott értékelővektor

$$
\mathbf{q}(N, A, M)=\left[\begin{array}{llllllll}
11 / 16 & 13 / 16 & 3 / 16 & 3 / 16 & 3 / 16 & -11 / 16 & -11 / 16 & -11 / 16
\end{array}\right]^{\top},
$$

amiből $X_{1} \prec \underset{(N, A, M)}{\mathrm{q}} X_{2}$, ez pedig ellentmond a lineáris rendezés megőrzésének.

5.10. Megjegyzés. Az 5.2. Megjegyzés szerint minden $f: \mathcal{R}^{n} \rightarrow \mathbb{R}^{n}$ semleges pontozási eljárásra az 5.5. Példában $f_{3}(N, A, M)=f_{4}(N, A, M)=f_{5}(N, A, M)$, az 5.6. Példában $f_{3}(N, A, M)=f_{4}(N, A, M)=f_{5}(N, A, M)$ és $f_{6}(N, A, M)=f_{7}(N, A, M)=$ $=f_{8}(N, A, M)$.

${ }^{15}$ Az észrevételért köszönettel tartozunk Pavel Chebotarevnek. 
5.4. ábra. Az 5.6. Példa rangsorolási problémája

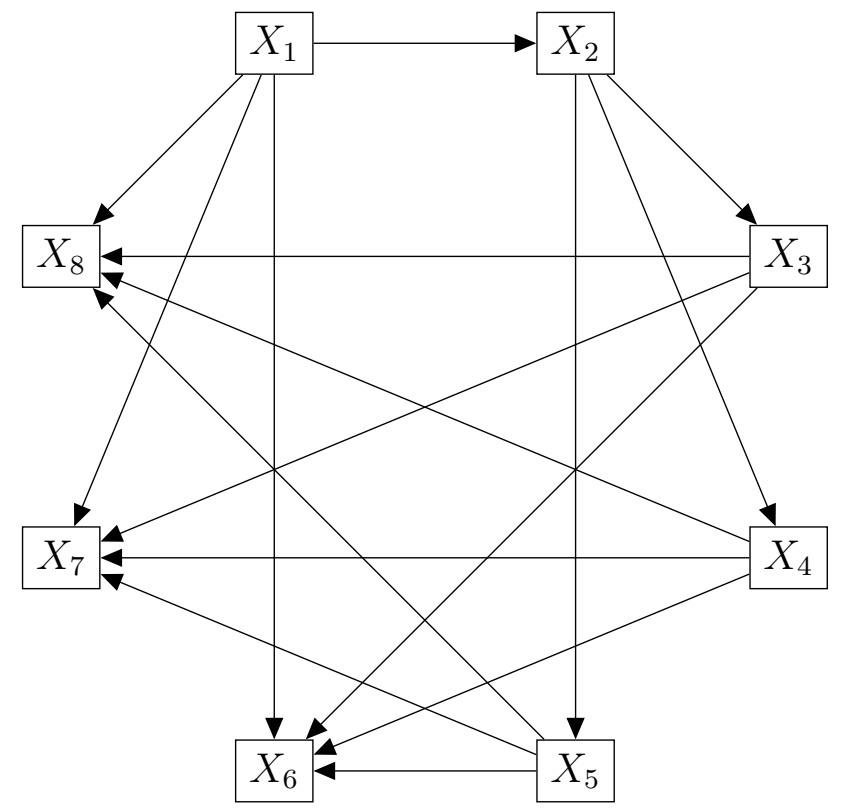

Az 5.11. Állítás és az 5.1. Tétel értelmében az általánosított sorösszeg módszer határértékeként adódó pontozási eljárások egyike sem teljesíti az LOP tulajdonságot, ezért valószínüsíthető a következő sejtés.

3. Sejtés. Az általánosított sorösszeg módszer egyetlen rögzített $\varepsilon$ mellett sem őrzi meg a lineáris rendezést.

Ezt az 5.5. Példa bizonyítja $\varepsilon=1 / 6$-ra, az 5.6. Példa pedig $\varepsilon=3 / 5$-re, és minden bizonnyal bármely más, az előbbinél kisebb, illetve az utóbbinál nagyobb $\varepsilon$-ra is.

4. Sejtés. Az 5.6. Példa az objektumok számára nézve minimális: $n \leq 7$ esetén nem találhatunk olyan $(N, A, M) \in \mathcal{R}^{n}$ rangsorolási problémát, melyre a legkisebb négyzetek módszere megsérti a lineáris rendezés megörzését.

5.11. Megjegyzés. Az LOP axióma 5.14. Definíciójának egy természetes erösítése lenne az $f_{i}(N, A, M) \geq f_{j}(N, A, M)$ feltétel helyett $f_{i}(N, A, M)>f_{j}(N, A, M)$ elöírása, ezt a név módszer már nem teljesítené. Ekkor az 5.5. és az 5.6. Példa módosításával a pontszám módszerre $n=4$, a legkisebb négyzetekre $n=7$ mellett is létezne ellenpélda.

A lineáris rendezés megörzésének korlátozott értelmezési tartományokon (például $\mathcal{R}_{B}$ vagy $\left.\mathcal{R}_{U}\right)$ történő vizsgálata további kutatásokat igényel.

\subsection{Az összehasonlítások megváltozásának hatása}

Arrow híres lehetetlenségi tétele (Arrow, 1951) óta a társadalmi választások elméletének egyik központi kérdése az irreleváns alternatívák vizsgálata. Model- 
lünk érzékeny az objektumok halmazának módosítására, a páros összehasonlítások tekintetében azonban megfogalmazható néhány ilyen jellegű követelmény.

\subsubsection{Függetlenség az irreleváns összehasonlításoktól}

Először egy, az irodalomban korábban bevezetett axiómát ismertetünk.

5.15. Definíció. Függetlenség az irreleváns mérkőzésektől (independence of irrelevant matches, IIM) (González-Díaz et al., 2014) : Legyen $(N, A, M) \in \mathcal{R}^{n}$ egy rangsorolási probléma, $X_{i}, X_{j}, X_{k}, X_{\ell} \in N$ négy különböző objektum, és $f: \mathcal{R}^{n} \rightarrow \mathbb{R}^{n}$ egy pontozási eljárás, amire $f_{i}(N, A, M) \geq f_{j}(N, A, M)$. Legyen $\left(N, A^{\prime}, M^{\prime}\right) \in \mathcal{R}^{n}$ egy olyan rangsorolási probléma, ami azonos $(N, A, M)$-mel, de $a_{k \ell}^{\prime} \neq a_{k \ell}$ és $m_{k \ell}^{\prime} \in \mathbb{N}$ tetszőleges. $f$ független az irreleváns mérkőzésektöl, ha $f_{i}\left(N, A^{\prime}, M^{\prime}\right) \geq f_{j}\left(N, A^{\prime}, M^{\prime}\right)$.

Az IIM teljesülése esetén minden olyan összehasonlítás száma és kimenetele irreleváns, amely nem érinti a két vizsgált objektum egyikét sem.

Ezt a tulajdonságot Rubinstein (1980, Axiom III), illetve Nitzan és Rubinstein (1981, Axiom 5) függetlenség (independence) néven említi körmérkőzéses rangsorolási problémák esetén, amikor az $M$ mérkőzésmátrix értelemszerűen nem változhat. Altman és Tennenholtz (2008, Definition 8.4) egy némileg szigorúbb axiómát definiál Arrow-féle irreleváns alternatíváktól való függetlenségként (Arrow's independence of irrelevant alternatives, $A I I A)$, az IIM azonban így is túl erősnek fog bizonyulni, ezért ezzel az iránnyal nem foglalkozunk. ${ }^{16}$

5.12. Megjegyzés. Az irreleváns mérkőzésektől való függetlenség $n \geq 4$ esetén értelmezhetö.

Az irreleváns mérkőzésektől való függetlenség alkalmazásával tetszőleges olyan $\left(N, A^{\prime}, M^{\prime}\right) \in \mathcal{R}^{n}$ rangsorolási problémához eljuthatunk, ahol $a_{g h}^{\prime}=a_{g h}$ és $m_{g h}^{\prime}=m_{g h}$, ha $\left\{X_{g}, X_{h}\right\} \cap\left\{X_{i}, X_{j}\right\} \neq \emptyset$, de az összes többi összehasonlítás száma és eredménye eltérö lehet.

Mivel az IIM tulajdonság nem zárja ki az összehasonlítási multigráf összefüggőségének megszünését, a legkisebb négyzetek módszerére történő értelmezéséhez szükséges az 1. Feltevés.

Az alábbi axióma gyengébb az irreleváns mérkőzésektől való függetlenségnél.

5.16. Definíció. Függetlenség az irreleváns eredményektől (independence of irrelevant results, $I I R)$ : Legyen $(N, A, M) \in \mathcal{R}^{n}$ egy rangsorolási probléma, $X_{i}, X_{j}, X_{k}$, $X_{\ell} \in N$ négy különböző objektum, és $f: \mathcal{R}^{n} \rightarrow \mathbb{R}^{n}$ egy pontozási eljárás, amire $f_{i}(N, A, M) \geq f_{j}(N, A, M)$. Legyen $\left(N, A^{\prime}, M\right) \in \mathcal{R}^{n}$ egy olyan rangsorolási probléma, ami azonos $(N, A, M)$-mel, de $a_{k \ell}^{\prime} \neq a_{k \ell} . f$ független az irreleváns eredményektől, ha $f_{i}\left(N, A^{\prime}, M\right) \geq f_{j}\left(N, A^{\prime}, M\right)$.

16 Altman és Tennenholtz (2008) megengedi, hogy az $X_{i}$-t és $X_{j}$-t érintő összehasonlítások kimenetele is módosuljon, amennyiben $a_{i h}-a_{i h}^{\prime}=a_{j h}-a_{j h}^{\prime}$ minden $X_{h} \in N \backslash\left\{X_{i}, X_{j}\right\}$-re. 
Az IIR teljesülésekor minden olyan összehasonlítás kimenetele irreleváns, amely nem érinti a két vizsgált objektum egyikét sem (IIM-mel szemben itt nem változhat az összehasonlítások száma).

5.13. Megjegyzés. Az IIR tulajdonság $n \geq 4$ esetén értelmezhető.

Az irreleváns eredményektől való függetlenség sorozatos alkalmazásával tetszőleges olyan $\left(N, A^{\prime}, M\right) \in \mathcal{R}^{n}$ rangsorolási problémához eljuthatunk, ahol $a_{g h}^{\prime}=a_{g h}$, ha $\left\{X_{g}, X_{h}\right\} \cap\left\{X_{i}, X_{j}\right\} \neq \emptyset$, de az összes többi összehasonlítás eredménye eltérő lehet.

$I I R$ a legkisebb négyzetek módszerére is gond nélkül értelmezhető, mert a megengedett változások nem befolyásolják a $G$ összehasonlítási multigráfot.

5.6. Következmény. Ha egy $f: \mathcal{R}^{n} \rightarrow \mathbb{R}^{n}$ pontozási eljárás kielégíti az IIM tulajdonságot, akkor az IIR-t is teljesíti.

5.10. Állítás. A pontszám módszer teljesíti az IIM tulajdonságot.

Bizonyítás. Lásd González-Díaz et al. (2014, 157. o.). Az s = Ae definíció alapján $s_{i}$ és $s_{j}$ független $a_{k \ell^{-}}$-tól és $m_{k \ell^{-}}$-től is.

5.14. Lemma. A pontszám módszer teljesíti az IIR tulajdonságot.

Bizonyítás. Az 5.10. Állításból és az 5.6. Következményből adódik.

5.11. Állítás. Az általánosított sorösszeg és a legkisebb négyzetek módszere nem teljesíti az IIR tulajdonságot.

Bizonyitás. A minimális, $n=4$ esetben egy példán keresztül bizonyítjuk az axióma megsértését (ennél kisebb méretre az irreleváns eredményektől való függetlenség nem értelmezhetö).

5.5. ábra. Az 5.7. Példa rangsorolási problémái

(a) $\mathrm{Az}(N, A, M)$ rangsorolási probléma

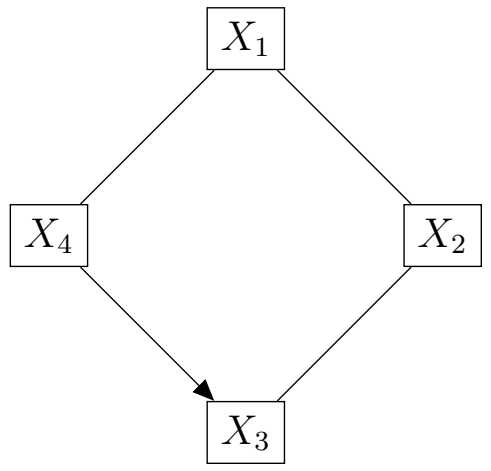

(b) $\mathrm{Az}\left(N, A^{\prime}, M\right)$ rangsorolási probléma

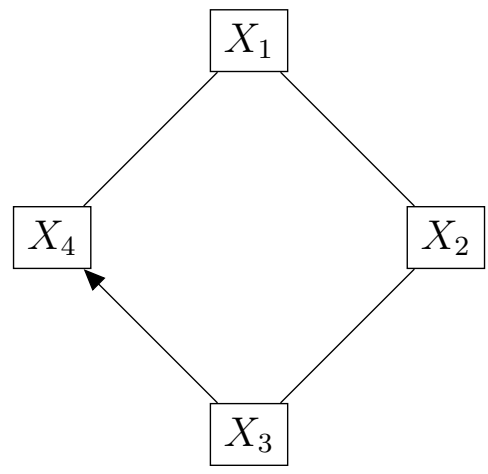


5.7. Példa. Legyen az $(N, A, M),\left(N, A^{\prime}, M\right) \in \mathcal{R}_{B}^{4} \cap \mathcal{R}_{U}^{4}$ kiegyensúlyozott és súlyozatlan rangsorolási problémákra (5.5. ábra):

$$
A=\left[\begin{array}{cccc}
0 & 0 & 0 & 0 \\
0 & 0 & 0 & 0 \\
0 & 0 & 0 & -1 \\
0 & 0 & 1 & 0
\end{array}\right], \quad A^{\prime}=\left[\begin{array}{cccc}
0 & 0 & 0 & 0 \\
0 & 0 & 0 & 0 \\
0 & 0 & 0 & 1 \\
0 & 0 & -1 & 0
\end{array}\right] \quad \text { és } \quad M=\left[\begin{array}{cccc}
0 & 1 & 0 & 1 \\
1 & 0 & 1 & 0 \\
0 & 1 & 0 & 1 \\
1 & 0 & 1 & 0
\end{array}\right] \text {. }
$$

Jelölje sorrendben $\mathbf{s}, \mathbf{x}(\varepsilon)$ és $\mathbf{q}$; illetve $\mathbf{s}^{\prime}, \mathbf{x}^{\prime}(\varepsilon)$ és $\mathbf{q}^{\prime}$ az egyes rangsorolási problémákhoz tartozó, a pontszám, az általánosított sorösszeg, és a legkisebb négyzetek módszerével kapott értékelővektorokat. Tehát $n=4, m=m^{\prime}=1, \mathbf{s}=[0,0,-1,1]^{\top}$ és $\mathbf{s}^{\prime}=[0,0,1,-1]^{\top}$, valamint

$$
I+\varepsilon L\left[\begin{array}{cccc}
1+2 \varepsilon & -\varepsilon & 0 & -\varepsilon \\
-\varepsilon & 1+2 \varepsilon & -\varepsilon & 0 \\
0 & -\varepsilon & 1+2 \varepsilon & -\varepsilon \\
-\varepsilon & 0 & -\varepsilon & 1+2 \varepsilon
\end{array}\right]
$$

Ekkor

$$
\begin{gathered}
x_{1}(\varepsilon)=x_{2}^{\prime}(\varepsilon)=(1+\varepsilon m n) \frac{\varepsilon}{(1+2 \varepsilon)(1+4 \varepsilon)}=\frac{\varepsilon}{1+2 \varepsilon} \text { és } \\
x_{1}^{\prime}(\varepsilon)=x_{2}(\varepsilon)=(1+\varepsilon m n) \frac{-\varepsilon}{(1+2 \varepsilon)(1+4 \varepsilon)}=\frac{-\varepsilon}{1+2 \varepsilon} .
\end{gathered}
$$

Vagyis $X_{1} \succ_{(N, A, M)}^{\mathbf{x}(\varepsilon)} X_{2}$ és $X_{1} \prec \underset{\left(N, A^{\prime}, M\right)}{\mathbf{x}(\varepsilon)} X_{2}$, ezért az általánosított sorösszeg egyetlen $\varepsilon$ paraméterre sem független az irreleváns eredményektől.

A példát a legkisebb négyzetek módszerével kiszámolva, a 3.3. Állítás értelmében

$$
\begin{gathered}
q_{1}=\frac{\lim _{\varepsilon \rightarrow \infty} x_{1}(\varepsilon)}{m n}=q_{2}^{\prime}=\frac{\lim _{\varepsilon \rightarrow \infty} x_{2}(\varepsilon)^{\prime}}{m n}=\frac{1}{2} \cdot \frac{1}{4}=\frac{1}{8} \text { és } \\
q_{1}^{\prime}=\frac{\lim _{\varepsilon \rightarrow \infty} x_{1}(\varepsilon)^{\prime}}{m n}=q_{2}=\frac{\lim _{\varepsilon \rightarrow \infty} x_{2}(\varepsilon)}{m n}=-\frac{1}{2} \cdot \frac{1}{4}=-\frac{1}{8} .
\end{gathered}
$$

Tehát $X_{1} \succ \underset{(N, A, M)}{\mathbf{q}} X_{2}$ és $X_{1} \prec \underset{\left(N, A^{\prime}, M\right)}{\mathbf{q}} X_{2}$, így a legkisebb négyzetek módszere sem teljesíti az $I I R$ tulajdonságot.

5.15. Lemma. Az általánosított sorösszeg és a legkisebb négyzetek módszere nem teljesíti az IIM tulajdonságot.

Bizonyítás. Lásd González-Díaz et al. (2014, Example 6.1). Az 5.11. Állításból és az 5.6. Következményből adódik.

5.2. Tétel. Ha egy $f: \mathcal{R}^{n} \rightarrow \mathbb{R}^{n}$ pontozási eljárás kielégíti a $N E U$, az $S Y M$ és a CS tulajdonságokat, akkor az IIM-et is teljesíti. 
Bizonyítás. A körmérkőzéses esetben lásd Nitzan és Rubinstein (1981, Lemma 3). ${ }^{17}$ Indirekt módon tegyük fel, hogy van olyan $(N, A, M) \in \mathcal{R}^{n}$ rangsorolási probléma, ahol $X_{i}, X_{j}, X_{k}, X_{\ell} \in N$ négy különbözö objektum, $f_{i}(N, A, M) \geq f_{j}(N, A, M)$, valamint $\left(N, A^{\prime}, M^{\prime}\right) \in \mathcal{R}^{n}$ egy olyan rangsorolási probléma, ami azonos $(N, A, M)$ mel, de $a_{k \ell}^{\prime} \neq a_{k \ell}$ és $f_{i}\left(N, A^{\prime}, M^{\prime}\right)<f_{j}\left(N, A^{\prime}, M^{\prime}\right)$. Az 5.7. Állítás szerint az $f$ szimmetrikus és konzisztens pontozási eljárás megfordítható, így $f_{i}(N,-A, M) \leq$ $\leq f_{j}(N,-A, M)$.

Legyen $\sigma:\left\{X_{1}, X_{2}, \ldots, X_{n}\right\} \rightarrow\left\{X_{1}, X_{2}, \ldots, X_{n}\right\}$ az a permutáció, melyre $\sigma\left(X_{i}\right)=X_{j}$ és $\sigma\left(X_{j}\right)=X_{i}$, illetve $\sigma\left(X_{k}\right)=X_{k}$ minden $X_{k} \in N \backslash\left\{X_{i}, X_{j}\right\}$ esetén. A semlegesség miatt $f_{i}[\sigma(N, A, M)] \leq f_{j}[\sigma(N, A, M)]$, a megfordíthatóságot és az 5.9. Megjegyzést hozzávéve $f_{i}\left[\sigma\left(N,-A^{\prime}, M^{\prime}\right)\right]<f_{j}\left[\sigma\left(N,-A^{\prime}, M^{\prime}\right)\right]$. Eszerint $\sigma(A)-\sigma\left(A^{\prime}\right)-A+A^{\prime}=O$ következtében $f$ konzisztens volta miatt $f_{i}\left(N, O, M^{\prime \prime}\right)<$ $<f_{j}\left(N, O, M^{\prime \prime}\right)$, ahol $M^{\prime \prime}=2 M+2 M^{\prime}$. Viszont a szimmetriából $f_{i}\left(N, O, M^{\prime \prime}\right)=$ $=f_{j}\left(N, O, M^{\prime \prime}\right)$, ami ellentmondás.

5.12. Állítás. Ha egy $f: \mathcal{R}^{n} \rightarrow \mathbb{R}^{n}$ pontozási eljárás kielégíti a $N E U$, az $S Y M$ és a CS tulajdonságokat, akkor az IIR-t is teljesíti.

Bizonyítás. Követhető az 5.2. Tétel bizonyítása. Az 5.7. Állítás szerint egy $f$ szimmetrikus és eredmény konzisztens pontozási eljárás is megfordítható. Ugyanakkor $f_{i}\left(N, O, M^{\prime \prime}\right)<f_{j}\left(N, O, M^{\prime \prime}\right)$ fennállása csak akkor biztosított az eredmény konzisztenciából, ha $M=M^{\prime}$.

González-Díaz et al. (2014, 165. o.) a pontszám módszer hibájaként rója fel, hogy hiányos és többszörös összehasonlítások jelenlétében is független az irreleváns mérkőzésektől, tehát az általános esetben az IIM egy nemkívánatos tulajdonság. ${ }^{18}$ Ekkor az 5.2. Tétel értelmében, mivel a semlegesség és a szimmetria aligha vitatható, a konzisztencia fennállása könnyen támadható. Ez rámutat az 5.3.2. szakasz, az additivitás gyengítésének jelentőségére.

\subsubsection{Függetlenség a döntetlenektöl}

Az alfejezetben egyfajta dinamikus nézőpontból a döntetlenek $\left(a_{i j}=0\right)$ következményeit ismertetjük. Ehhez ismét némi előkészítés szükséges.

5.17. Definíció. Döntetlenek elfogadható transzformációja (admissible transformation of draws): Legyen $(N, A, M) \in \mathcal{R}^{n}$ egy rangsorolási probléma, $X_{i}, X_{j} \in N$ két objektum. Az $X_{i}$ és $X_{j}$ közötti döntetlenek elfogadható transzformációja egy olyan

${ }^{17}$ A hivatkozott cikkből nem sikerült teljes mértékben rekonstruálnunk a bizonyítást, valószínűleg elírás történt. Az általános esetben $I I M$ és $I I R$ már nem ekvivalens, utóbbi gyengébb feltétel.

18 So when players have different opponents (or face opponents with different intensities), IIM is a property one would rather not have (González-Díaz et al., 2014, 165. o.). 
$\left(N, A, M^{\prime}\right) \in \mathcal{R}^{n}$ rangsorolási problémát eredményez, amire $m_{i j}^{\prime} \geq\left|a_{i j}\right|$ és $m_{k \ell}^{\prime}=m_{k \ell}$ minden $\left(X_{k}, X_{\ell}\right) \neq\left(X_{i}, X_{j}\right)$-re.

$m_{i j}^{\prime}$ értékét az $\mathcal{R}^{n}$ értelmezési tartományon belül maradás érdekében szükséges alulról korlátozni. $a_{i j} \in\left\{-m_{i j} ; m_{i j}\right\}$ esetén csak $m_{i j}^{\prime}>m_{i j}$ lehetséges.

5.8. Példa. Az 5.1. Példában $a_{12}=1$, ezért $\left(N, A, M^{\prime}\right) \in \mathcal{R}^{n}$ a döntetlenek elfogadható transzformációjával kapható rangsorolási probléma, ha $m_{12}^{\prime} \geq 1$.

5.18. Definíció. Függetlenség a döntetlenektől (independence of draws, $I D)$ : Legyen $(N, A, M),\left(N, A, M^{\prime}\right) \in \mathcal{R}^{n}$ két rangsorolási probléma, ahol $\left(N, A, M^{\prime}\right)$ az $X_{i}$ és $X_{j}$ közötti döntetlenek elfogadható transzformációjával kapható $(N, A, M)$-ből. Egy $f$ pontozási eljárás független a döntetlenektöl, ha $f_{i}(N, A, M)>f_{j}(N, A, M) \Leftrightarrow$ $f_{i}\left(N, A, M^{\prime}\right)>f_{j}\left(N, A, M^{\prime}\right)$.

Az ID tulajdonság értelmében két objektum egymás közötti döntetlen mérkőzéseinek száma tetszőlegesen növelhető (illetve, ha kezdetben volt ilyen eredmény, akkor bizonyos mértékben csökkenthető), anélkül, hogy megváltozna relatív értékelésük.

5.14. Megjegyzés. Ha egy $f: \mathcal{R}^{n} \rightarrow \mathbb{R}^{n}$ pontozási eljárás kielégíti az $I D$ tulajdonságot, akkor $f_{i}(N, A, M)=f_{j}(N, A, M) \Leftrightarrow f_{i}\left(N, A, M^{\prime}\right)=f_{j}\left(N, A, M^{\prime}\right)$ minden $X_{i}, X_{j} \in$ $\in N$-re.

5.7. Következmény. Ha egy $f: \mathcal{R}^{n} \rightarrow \mathbb{R}^{n}$ pontozási eljárás kielégíti az IIM tulajdonságot, akkor az ID-t is teljesíti.

5.16. Lemma. A pontszám módszer teljesíti az ID tulajdonságot.

Bizonyítás. Az 5.10. Állításból és az 5.7. Következményből adódik.

5.13. Állítás. Az általánosított sorösszeg, és a legkisebb négyzetek módszere is teljesíti az ID tulajdonságot.

Bizonyítás. Jelölje $x_{i}=x_{i}(\varepsilon)(N, A, M), x_{i}^{\prime}=x_{i}(\varepsilon)\left(N, A, M^{\prime}\right)$, és $s_{i}=s_{i}(N, A, M)=$ $=s_{i}\left(N, A, M^{\prime}\right)$ minden $X_{i} \in N$-re. Indirekt módon tegyük fel, hogy $x_{i} \geq x_{j}$ és $x_{i}^{\prime}<x_{j}^{\prime}$, azaz $x_{j}^{\prime}-x_{j}>x_{i}^{\prime}-x_{i}$. Legyen $x_{k}^{\prime}-x_{k}=\max _{X_{\ell} \in N}\left(x_{\ell}^{\prime}-x_{\ell}\right)$. Ekkor két eset lehetséges, $X_{k}=X_{j}$ vagy $X_{k} \neq X_{j}$. Kezdjük az utóbbival. A két rangsorolási problémában az $X_{k} \in N$ objektumra vonatkozó egyenletek különbségéből:

$0=(1+\varepsilon m n)\left(s_{k}^{\prime}-s_{k}\right)=\left(x_{k}^{\prime}-x_{k}\right)+\varepsilon \sum_{X_{\ell} \in N} m_{k \ell}\left[\left(x_{k}^{\prime}-x_{k}\right)-\left(x_{\ell}^{\prime}-x_{\ell}\right)\right] \geq\left(x_{k}^{\prime}-x_{k}\right)$.

A CNT axióma (5.4. Lemma) miatt $\sum_{X_{\ell} \in N} x_{\ell}=\sum_{X_{\ell} \in N} x_{\ell}^{\prime}=0$, azaz $x_{k}^{\prime}-x_{k}>0$, mert $x_{j}^{\prime}-x_{j}>x_{i}^{\prime}-x_{i}$ alapján $\mathbf{x}^{\prime} \neq \mathbf{x}$. Ez ellentmondásra vezet. 
Tehát $x_{j}^{\prime}-x_{j}=\max _{X_{\ell} \in N}\left(x_{\ell}^{\prime}-x_{\ell}\right)$. A két rangsorolási problémában az $X_{j} \in N$ objektumra vonatkozó egyenletek különbségéből:

$$
\begin{aligned}
0 & =(1+\varepsilon m n)\left(s_{j}^{\prime}-s_{j}\right)= \\
& =\left(x_{j}^{\prime}-x_{j}\right)+\varepsilon\left\{\sum_{X_{\ell} \neq X_{i}} m_{j \ell}\left[\left(x_{j}^{\prime}-x_{j}\right)-\left(x_{\ell}^{\prime}-x_{\ell}\right)\right]+m_{i j}^{\prime}\left(x_{j}^{\prime}-x_{i}^{\prime}\right)-m_{i j}\left(x_{j}-x_{i}\right)\right\} .
\end{aligned}
$$

Itt $x_{j}^{\prime}-x_{j}>0$, mert $x_{j}^{\prime}-x_{j}>x_{i}^{\prime}-x_{i}$ alapján $\mathbf{x}^{\prime} \neq \mathbf{x}$, és az általánosított sorösszeg zérusösszegü. Ugyanakkor $\left(x_{j}^{\prime}-x_{j}\right)-\left(x_{\ell}^{\prime}-x_{\ell}\right) \geq 0$, valamint az indirekt feltevés értelmében $\left(x_{j}^{\prime}-x_{i}^{\prime}\right)>0$ és $\left(x_{j}-x_{i}\right) \leq 0$, ami lehetetlen.

A legkisebb négyzetek módszerére ugyanez a gondolatmenet alkalmazható. Az egyetlen változás, hogy $X_{k} \neq X_{j}$ esetén

$$
0=(1+\varepsilon m n)\left(s_{k}^{\prime}-s_{k}\right)=\varepsilon \sum_{X_{\ell} \in N} m_{k \ell}\left[\left(q_{k}^{\prime}-q_{k}\right)-\left(q_{\ell}^{\prime}-q_{\ell}\right)\right] \geq q_{k}^{\prime}-q_{k} \geq 0
$$

még nem feltétlenül mond ellent az indirekt feltevésnek, viszont csak akkor lehetséges, ha $q_{k}^{\prime}-q_{k}=q_{\ell}^{\prime}-q_{\ell}$ minden olyan $X_{\ell} \in N$-re, ahol $m_{k \ell}>0$. Ekkor azonban bármely, az $X_{k}$-val összehasonlított objektum átveheti $X_{k}$ szerepét, így az összefüggőség miatt elöbb-utóbb eljutunk egy olyan $X_{h} \in N$-hez, amire $q_{h}^{\prime}-q_{h}=\max _{X_{\ell} \in N}\left(q_{\ell}^{\prime}-q_{\ell}\right)>$ $>q_{i}^{\prime}-q_{i}$ és $m_{h i}>0$, ami már lehetetlen.

Ennél valamivel többet is tudunk mondani az $X_{i}$ és $X_{j}$ közötti döntetlenek száma változásának következményeiről.

5.14. Állítás. Az eredeti $(N, A, M) \in \mathcal{R}^{n}$ és a módosított $\left(N, A, M^{\prime}\right) \in \mathcal{R}^{n}$ rangsorolási problémák függvényében a pontszám, az általánositott sorösszeg, és a legkisebb négyzetek módszerére egyaránt teljesülnek az alábbiak:

- $f_{i}(N, A, M)=f_{j}(N, A, M) \Rightarrow f_{k}\left(N, A, M^{\prime}\right)=f_{k}(N, A, M) \operatorname{minden} X_{k} \in$ $\in N-r e$

- $\left[f_{i}(N, A, M)>f_{j}(N, A, M), m_{i j}<m_{i j}^{\prime}\right] \Rightarrow f_{i}\left(N, A, M^{\prime}\right)>f_{j}\left(N, A, M^{\prime}\right)$, valamint $f_{i}\left(N, A, M^{\prime}\right)-f_{i}(N, A, M) \leq f_{k}\left(N, A, M^{\prime}\right)-f_{k}(N, A, M) \leq$ $\leq f_{j}\left(N, A, M^{\prime}\right)-f_{j}(N, A, M)$ minden $X_{k} \in N-r e$.

Bizonyítás. A 3.1. Megjegyzés szerint a pontszám és az általánosított sorösszeg módszerek együtt kezelhetők. Jelölje $x_{i}=x_{i}(\varepsilon)(N, A, M)$ és $x_{i}^{\prime}=x_{i}(\varepsilon)\left(N, A, M^{\prime}\right)$ minden $X_{i} \in N$-re. Ha az 5.13. Állítás bizonyítását az indirekt feltevés nélkül tekintjük, akkor $x_{k}^{\prime}-x_{k}=\max _{X_{\ell} \in N}\left(x_{\ell}^{\prime}-x_{\ell}\right)$ és $X_{k} \in N \backslash\left\{X_{i}, X_{j}\right\}$ csak úgy lehetséges, hogy $x_{k}^{\prime}-x_{k}=0$. Ebből a $C N T$ tulajdonság felhasználásával $x_{i}=x_{j}$ és $x_{i}^{\prime}=x_{j}^{\prime}$. Analóg módon belátható, hogy $x_{k}^{\prime}-x_{k}=\min _{X_{\ell} \in N}\left(x_{\ell}^{\prime}-x_{\ell}\right)$ és $X_{k} \in N \backslash\left\{X_{i}, X_{j}\right\}$ esetén $x_{k}^{\prime}-x_{k}=0$, azaz $x_{i}=x_{j}$ és $x_{i}^{\prime}=x_{j}^{\prime}$. Eszerint $x_{i}^{\prime}-x_{i}=\max _{X_{\ell} \in N}\left(x_{\ell}^{\prime}-x_{\ell}\right)$ $\operatorname{vagy} x_{i}^{\prime}-x_{i}=\min _{X_{\ell} \in N}\left(x_{\ell}^{\prime}-x_{\ell}\right)$. 
Legyen $x_{i} \leq x_{j}$ és $m_{i j}^{\prime}>m_{i j}$. A két rangsorolási problémában az $X_{i} \in N$ objektumra vonatkozó egyenletek különbségéből:

$$
\begin{aligned}
0 & =(1+\varepsilon m n)\left(s_{i}^{\prime}-s_{i}\right)= \\
& =\left(x_{i}^{\prime}-x_{i}\right)+\varepsilon\left\{\sum_{X_{\ell} \neq X_{i}} m_{i \ell}\left[\left(x_{i}^{\prime}-x_{i}\right)-\left(x_{\ell}^{\prime}-x_{\ell}\right)\right]+m_{i j}^{\prime}\left(x_{i}^{\prime}-x_{j}^{\prime}\right)-m_{i j}\left(x_{i}-x_{j}\right)\right\} .
\end{aligned}
$$

Legyen $x_{i}^{\prime}-x_{i}=\min _{X_{\ell} \in N}\left(x_{\ell}^{\prime}-x_{\ell}\right) \leq 0$. Ekkor $m_{i j}^{\prime}\left(x_{i}^{\prime}-x_{j}^{\prime}\right) \leq m_{i j}\left(x_{i}-x_{j}\right) \leq 0$, ami csak akkor nem vezet ellentmondásra, ha $x_{j}^{\prime}-x_{j}=\min _{X_{\ell} \in N}\left(x_{\ell}^{\prime}-x_{\ell}\right)=0$. Ebböl a zérusösszegüség alapján $x_{\ell}^{\prime}-x_{\ell}=0$ minden $X_{\ell} \in N$-re.

Hasonlóan, a két rangsorolási problémában az $X_{j} \in N$ objektumra vonatkozó egyenletek különbségéből:

$$
\begin{aligned}
0 & =(1+\varepsilon m n)\left(s_{j}^{\prime}-s_{j}\right)= \\
& =\left(x_{j}^{\prime}-x_{j}\right)+\varepsilon\left\{\sum_{X_{\ell} \neq X_{j}} m_{j \ell}\left[\left(x_{j}^{\prime}-x_{j}\right)-\left(x_{\ell}^{\prime}-x_{\ell}\right)\right]+m_{i j}^{\prime}\left(x_{j}^{\prime}-x_{i}^{\prime}\right)-m_{i j}\left(x_{j}-x_{i}\right)\right\} .
\end{aligned}
$$

Legyen $x_{j}^{\prime}-x_{j}=\max _{X_{\ell} \in N}\left(x_{\ell}^{\prime}-x_{\ell}\right) \geq 0$. Ekkor $m_{i j}^{\prime}\left(x_{i}^{\prime}-x_{j}^{\prime}\right) \geq m_{i j}\left(x_{i}-x_{j}\right) \geq 0$, ami csak akkor nem vezet ellentmondásra, ha $x_{i}^{\prime}-x_{i}=\max _{X_{\ell} \in N}\left(x_{\ell}^{\prime}-x_{\ell}\right)=0$. Ebből a zérusösszegüség alapján $x_{\ell}^{\prime}-x_{\ell}=0$ minden $X_{\ell} \in N$-re.

A rangsorolási probléma összefüggőségének feltételezése mellett ugyanez érvényes a legkisebb négyzetek módszerére, az 5.13. Állítás bizonyításával analóg módon.

Az 5.14. Állítás szerint az $X_{j}$-vel szemben elért döntetlenek számának növekedése akkor kedvező az $X_{i}$ objektum számára, ha eredetileg gyengébb, csökkenése pedig akkor, ha eredetileg erősebb volt. Ez egy természetes követelmény.

5.15. Megjegyzés. Chebotarev (1994, Property 14) dinamikus monotonitás tulajdonságának (2) feltétele részben megfelel az ID axiómának: észszerü $\varepsilon$ paraméter mellett egy hiányzó $r_{i j}^{(p)}$ páros összehasonlítás döntetlenné változtatása, az $X_{i}$ és $X_{j}$ objektumok közötti döntetlenek számának növekedése esetén $f_{i}(N, A, M)=$ $=f_{j}(N, A, M) \Rightarrow f_{i}\left(N, A, M^{\prime}\right)=f_{j}\left(N, A, M^{\prime}\right)$, sőt, teljesül Chebotarev (1994, Property 11) monotonitás axiómájának első négy követelménye, vagyis az $x_{i}=$ $=x_{i}(\varepsilon)(N, A, M)$ és $x_{i}^{\prime}=x_{i}(\varepsilon)\left(N, A, M^{\prime}\right)$ minden $X_{i} \in N$-re jelöléssel $x_{i}>x_{j}$ mellett

1. $x_{j}^{\prime}-x_{j}>0$ és $x_{i}^{\prime}-x_{i}<0$;

2. $x_{j}^{\prime}-x_{j}=\max \left\{x_{k}^{\prime}-x_{k}: X_{k} \in N\right\}$ és $x_{i}^{\prime}-x_{i}=\min \left\{x_{k}^{\prime}-x_{k}: X_{k} \in N\right\}$, a bizonyítás alapján mindkettő az egyetlen maximum és minimum;

3. Ha létezik $X_{k}$-ból $X_{j}$-be vezetö út, és minden $X_{k}$-ből $X_{i}$-be vezetó út átmegy $X_{j}$-n, akkor $\Delta x_{k}>0$. Ha létezik $X_{k}$-ból $X_{i}$-be vezető út, és minden $X_{k}$-ből 
$X_{j}$-be vezető út átmegy $X_{i}$-n, akkor $\Delta x_{k}<0$.

4. Ha $\Delta x_{k}>0$, akkor létezik olyan $X_{k}$-ból $X_{j}$-be vezető út, mely minden objektumának értékelése szigorúan növekszik.

Ha $\Delta x_{k}<0$, akkor létezik olyan $X_{k}$-ból $X_{i}$-be vezető út, mely minden objektumának értékelése szigorúan csökken.

$X_{i}$ és $X_{j}$ azonos kezdeti értékelésekor egyetlen $X_{k} \in N$ objektum értékelése sem módosul.

Az $I D$ tulajdonság értelmében az $X_{i}$ és $X_{j}$ közötti döntetlenek számának változása a relatív értékelésüket nem befolyásolja. Az viszont általában nem igaz, hogy ez a többi objektum közül kiválasztott tetszőleges pár rangsorban elfoglalt helyét sem befolyásolná, amint azt a következő állítás mutatja.

5.15. Állítás. A legkisebb négyzetek módszerére a döntetlenek elfogadható transzformációja befolyásolhatja a rangsort.

Bizonyítás. Olyan $(N, A, M),\left(N, A, M^{\prime}\right) \in \mathcal{R}^{n}$ rangsorolási problémákat keresünk, hogy $q_{k}(N, A, M)>q_{\ell}(N, A, M)$ és $q_{k}\left(N, A, M^{\prime}\right)<q_{\ell}\left(N, A, M^{\prime}\right)$ az $X_{k}, X_{\ell} \in N$ objektumokra. Egy minimális méretű $(n=4)$ példán keresztül igazoljuk az állítást.

5.6. ábra. Az 5.9. Példa rangsorolási problémái

(a) $\mathrm{Az}(N, A, M)$ rangsorolási probléma

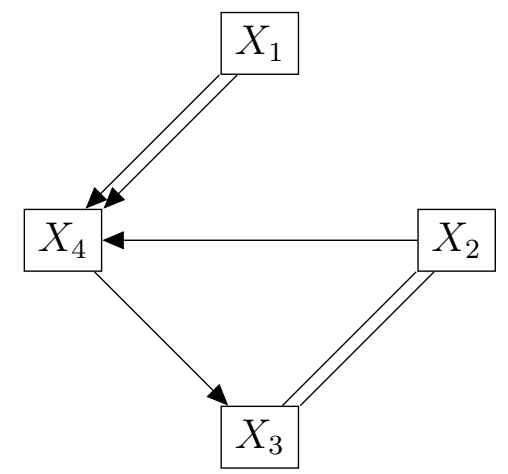

(b) $\mathrm{Az}\left(N, A, M^{\prime}\right)$ rangsorolási probléma

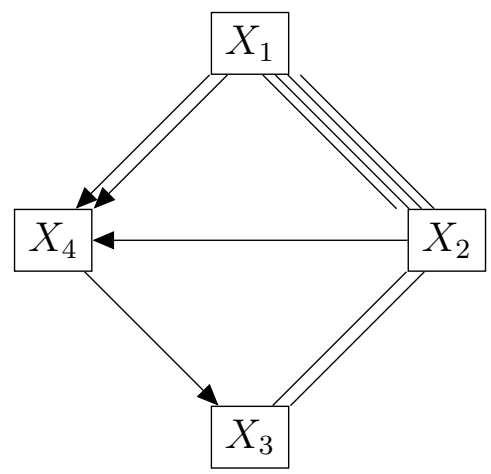

5.9. Példa. Legyen az $(N, A, M),\left(N, A, M^{\prime}\right) \in \mathcal{R}^{4}$ rangsorolási problémákra (5.6. ábra):

$$
A=\left[\begin{array}{cccc}
0 & 0 & 0 & 2 \\
0 & 0 & 0 & 1 \\
0 & 0 & 0 & -1 \\
-2 & -1 & 1 & 0
\end{array}\right] \quad \text { és } \quad M=\left[\begin{array}{llll}
0 & 0 & 0 & 2 \\
0 & 0 & 2 & 1 \\
0 & 2 & 0 & 1 \\
2 & 1 & 1 & 0
\end{array}\right], \quad M^{\prime}=\left[\begin{array}{llll}
0 & 4 & 0 & 2 \\
4 & 0 & 2 & 1 \\
0 & 2 & 0 & 1 \\
2 & 1 & 1 & 0
\end{array}\right] \text {. }
$$

Az $\left(N, A, M^{\prime}\right) \in \mathcal{R}^{4}$ rangsorolási probléma az $X_{1}$ és $X_{2}$ közötti döntetlenek elfogadható transzformációjával kapható $(N, A, M)$-ből. 
A legkisebb négyzetek módszerével kapott értékelővektorok

$$
\begin{gathered}
\mathbf{q}=[3 / 4,-1 / 20,-9 / 20,-1 / 4]^{\top} \text { és } \\
\mathbf{q}=[41 / 108,25 / 108,-31 / 108,-35 / 108]^{\top},
\end{gathered}
$$

$\operatorname{azaz} X_{3} \prec \underset{(N, A, M)}{\mathbf{q}} X_{4}$, de $X_{3} \succ \underset{(N, A, M)}{\mathbf{q}} X_{4}$.

5. Sejtés. Az általánosított sorösszeg módszerre a döntetlenek elfogadható transzformációja minden e paraméter mellett befolyásolhatja a rangsort.

Ezt az 5.9. Példa bizonyítja $\varepsilon=3 / 5$-re, és valószínüleg bármely más, ennél nagyobb $\varepsilon$-ra is.

A pontszám módszerre természetesen nem mondható ki az 5.15. Állításhoz és az 5. Sejtéshez hasonló eredmény, mert a döntetlenek elfogadható transzformációja nem hat az $A$ eredménymátrixra.

\section{6. Összegzés}

Ebben a fejezetben González-Díaz et al. (2014) elemzéséhez hasonlóan axiomatikus szempontból vizsgáltuk a pontozási eljárásokat az egymással rokon pontszám, általánosított sorösszeg és legkisebb négyzetek módszerén keresztül. A tulajdonságok jelentős része ismert a korábbi irodalomból - minden esetben ki is tértünk az ismert megjelenési helyekre -, de tudomásunk szerint több itt szerepel először. Az 5.1. alfejezet a rangsor változatlanságának legegyszerübb eseteit tárgyalta: az 5.1.1. szakasz a függetlenséget a szavazók és az objektumok nevétől ( $A N O$ és $N E U$ ), az 5.1.2. rész pedig, egy technikai tulajdonságon $(C N T)$ kívül, az összehasonlítások eredményével való lineáris kapcsolatot $(L R C R)$.

Az 5.2. alfejezet témája a rangsorolási problémák multiplikatív transzformációja volt, elsőként az eredmény- és a mérkőzésmátrix $(H O M)$, majd csak az előbbi vonatkozásában $(S I)$. Ezt értelemszerüen az additivitás vizsgálata egészítette ki az 5.3. részben. Egy példán keresztül megmutattuk, hogy mind az általánosított sorösszeg, mind a legkisebb négyzetek módszere megsérti a lehető legáltalánosabb axiómát $(C S)$ (5.3.1. szakasz). Ennek gyengítésére két lehetőséget vázoltunk, az egyenlőség őrzés $(F P)$ tekintetében pozitív eredményt kaptunk, míg az eredmény konzisztenciát $(R C S)$ az általánosított sorösszeg sejtésünk szerint egyetlen rögzített $\varepsilon$-ra sem teljesíti (5.3.2. szakasz).

Mivel az 5.2. Tétel szerint az összeadhatóság és az irreleváns mérkőzésektől való függetlenség lényegében ugyanazt jelenti, hiányos és többszörös összehasonlítások mellett pedig az utóbbi nem elvárható (González-Díaz et al., 2014, 165. o.), az általános esetben az eredmény konzisztencia tűnik a legerősebb additivitási tulajdonságnak, 
vagyis a rangsor változatlansága kizárólag azonos mérkőzésmátrixszal rendelkező részproblémákra összeadásakor garantált. Az 5.12. Állítás szerint azonban még ekkor sem állhat fenn az irreleváns eredményektől való függetlenség. A legkisebb négyzetek módszere mindig teljesíti az $R C S$ axiómát, az általánosított sorösszeg viszont csak bizonyos esetekben (5.6. Állítás).

Az 5.4. alfejezetben az eredménymátrix és az objektumok pontozási eljárással kapott sorrendjének kapcsolatát elemeztük. Két jól ismert tulajdonság a szimmetria $(S Y M)$ és a megfordíthatóság $(I N V)$, bár előbbit elsősorban a körmérkőzéses esetben használták. Az 5.4.1. részben összefüggésük csaknem minden részletét áttekintettük. Az 5.4.2. szakaszban, innovatív módon, a két rangsorolási megközelítés, az optimális lineáris rendezés és a pontozási eljárások egyesítésére tettünk kísérletet az $L O P$ axióma segítségével. Vizsgálatunk negatív következtetéssel zárult, az összeköttetés nem tűnik lehetségesnek.

Végül az 5.5. alfejezetben az irreleváns összehasonlítások problémájával foglalkoztunk. Miután ezek adnak információt a többi objektum teljesítményéről, csak a pontszám módszer független tőlük (5.5.1. szakasz). Ez tulajdonság gyengíthető $(I I R)$, ha az összehasonlítások száma nem módosulhat. Az 5.5.2. rész a döntetlenek hatását vizsgálja. Bár egy ilyen eredménnyel végződő összehasonlítás nem feltétlenül irreleváns a többi objektum szempontjából (5.15. Állítás), a két érintett relatív értékelését nem módosítja.

Jelentősebb saját eredményeinket az alábbiakban foglalhatjuk össze:

1. Az általánosított sorösszeg változó, a mérkőzésszámtól megfelelő mértékben függő $\varepsilon$ paraméterrel történő alkalmazásának belátása a homogenitás és az eredmény konzisztencia segítségével (5.2. Állítás, 5.3. Állítás; 5.10. Lemma, 5.6. Állítás). ${ }^{19}$

2. A skála invariancia bevezetése (5.7. Definíció). Ennek megkövetelésével egy irreducibilis aggregált páros összehasonlítási mátrix reducibilissé tehető, így bizonyos pontozási eljárások esetén bővíthető az egyértelmű megoldásra vezető rangsorolási problémák halmaza. Gyakorlati jelentősége, hogy diszkrét eredmények mellett lehetővé teszi a paraméterek számának csökkentését.

3. A konzisztencia megsértésének belátása az általánosított sorösszeg módszerre (5.4. Állítás). ${ }^{20}$

4. Az eredmény konzisztencia definíciója (5.10. Definíció) és vizsgálata (5.5. Állítás; 5.10. Lemma, 5.6. Állítás).

19 González-Díaz et al. (2014, 145. o.) ugyan tárgyalja a homogenitást, de az $\bar{\varepsilon}=1 /[m(n-2)]$ észszerü felső határ használata miatt nem tesz említést teljesülésének nem triviális kérdéséről.

${ }^{20}$ González-Díaz et al. (2014, Example 4.2) egy ennél gyengébb axióma megsértését is megmutatta $\bar{\varepsilon}=1 /[m(n-2)]$ mellett. 
5. A szimmetria és a megfordíthatóság viszonyának részletes elemzése (5.7. és 5.8. Állítás).

6. A lineáris rendezés megőrzése axióma bevezetése (5.14. Definíció), mely kapcsolatot teremt a pontozási eljárások és a rangsorolási probléma lineáris rendezéssel közelítése között. Annak belátása, hogy a vizsgált módszerek mindegyike megsérti ezt (5.9. Állítás, illetve 5.1. Tétel, Rónyai Lajossal közösen).

7. A függetlenség az irreleváns eredményektől tulajdonság definíciója (5.16. Definíció). Az irreleváns mérkőzésektől (eredményektől) való függetlenség összekapcsolása a(z eredmény) konzisztenciával az általános esetben, az $\mathcal{R}$ halmazon (5.2. Tétel, 5.12. Állítás). Eszerint González-Díaz et al. (2014, 165. o.) érvelése alapján a semlegesség és a szimmetria elfogadásával le kell mondanunk az additivitásról.

8. A függetlenség a döntetlenektől axióma bevezetése (5.18. Definíció) és vizsgálata (5.13. és 5.14. Állítás), Chebotarev (1994, Property 14) dinamikus monotonitás tulajdonságának kiterjesztése a páros összehasonlítások számának csökkentésével.

A fóbb eredmények publikálása folyamatban van (Csató, 2014b).

A különböző axiómák eredetét és a velük kapcsolatos eredményeket az F.V. Függelék F.6., összefüggéseiket pedig az F.7. táblázata tartalmazza. Néhány további következtetés a disszertáció záró fejezetében olvasható. 


\section{6. fejezet}

\section{Kapcsolat a pontszám módszerrel}

Chess players with poor opening moves seldom win tournaments.

Bruce W. Menning

Az eddigi tárgyalásban a normatív megközelítést követtük, bár bizonyos utalásokat már tettünk az egyes tulajdonságok összeegyeztethetőségével kapcsolatban. Az axiómák megfogalmazásának egyik legfontosabb célja kétségtelenül a pontozási eljárások karakterizálása, amire a 2.4. alfejezetben ugyan kitértünk, de a részletesebb elemzést meggátolta a tulajdonságok ismeretének hiánya. Így ezek bemutatása után érdemesnek tartjuk egy ilyen eredmény ismertetését. Néhány további karakterizációhoz - a 2.4. alfejezetben megadott cikkeken kívül - lásd Csató (2013d).

\subsection{Karakterizáció a körmérkőzéses esetben}

$\mathrm{Az} \mathcal{R}_{R}$ halmazon érvényes axiomatizáció kimondásához két újabb tulajdonság bevezetése szükséges.

\subsubsection{A szükséges tulajdonságok}

Az alábbi axióma a rangsor eredmények függvényében vett monotonitásával kapcsolatos.

6.1. Definíció. Erôs monotonitás (strong monotonicity, $S M$ ) (Bouyssou, 1992): Legyen $(N, A, M) \in \mathcal{R}^{n}$ egy rangsorolási probléma és $f: \mathcal{R}^{n} \rightarrow \mathbb{R}^{n}$ egy pontozási eljárás, amire $f_{i}(N, A, M) \geq f_{j}(N, A, M)$. Legyen $\left(N, A^{\prime}, M\right) \in \mathcal{R}^{n}$ egy olyan rangsorolási probléma, ami azonos $(N, A, M)$-mel, de létezik $X_{k} \in N \backslash\left\{X_{i}\right\}$, hogy $a_{i k}^{\prime}>a_{i k}$ (következésképp $\left.a_{k i}^{\prime}=-a_{i k}^{\prime}<-a_{i k}=a_{k i}\right)$. f erösen monoton, ha $f_{i}\left(N, A^{\prime}, M\right)>$ $>f_{j}\left(N, A^{\prime}, M\right)$. 
Vagyis, amennyiben $X_{i}$ nem volt hátrébb $X_{j}$-nél, és valamely objektummal szembeni összehasonlításának eredménye azok változatlan száma $\left(a_{i k}^{\prime}>a_{i k}\right.$ csak úgy lehetséges, hogy $\left.m_{i k}=m_{i k}^{\prime}>0\right)$ mellett javult, akkor az új rangsorban már szigorúan megelőzi $X_{j}$-t. A feltétel speciális esete, amikor $X_{k}=X_{j}$.

Ezt az egyik legkézenfekvőbb monotonitási tulajdonságot González-Díaz et al. (2014) és Csató (2012b) győzelemre adott pozitív reakció (positive responsiveness to the beating relation, $P R B)$ néven említi.

Rubinstein (1980, Axiom II) győzelemre adott pozitív reakció, illetve Nitzan és Rubinstein (1981, Axiom 2) monotonitás (monotonicity) tulajdonságai nem követelik meg a feltétel teljesülését a fenti speciális esetben, $X_{k}$ csak egy harmadik alternatíva lehet, ami némileg gyengébb követelmény az erős monotonitásnál.

6.2. Definíció. Közel erös monotonitás (close strong monotonicity, $C S M$ ) (Rubinstein, 1980): Legyen $(N, A, M) \in \mathcal{R}^{n}$ egy rangsorolási probléma és $f: \mathcal{R}^{n} \rightarrow \mathbb{R}^{n}$ egy pontozási eljárás, amire $f_{i}(N, A, M) \geq f_{j}(N, A, M)$. Legyen $\left(N, A^{\prime}, M\right) \in \mathcal{R}^{n}$ egy olyan rangsorolási probléma, ami azonos $(N, A, M)$-mel, de létezik $X_{k} \in N \backslash\left\{X_{i}, X_{j}\right\}$, hogy $a_{i k}^{\prime}>a_{i k}$ (következésképp $\left.a_{k i}^{\prime}=-a_{i k}^{\prime}<-a_{i k}=a_{k i}\right)$. $f$ közel erösen monoton, ha $f_{i}\left(N, A^{\prime}, M\right)>f_{j}\left(N, A^{\prime}, M\right)$.

6.1. Következmény. Ha egy $f: \mathcal{R}^{n} \rightarrow \mathbb{R}^{n}$ pontozási eljárás kielégíti az $S M$ tulajdonságot, akkor a CSM-et is teljesiti.

6.1. Lemma. A pontszám és az általánosított sorösszeg módszer teljesíti az SM tulajdonságot.

Bizonyítás. A pontszám módszerre a definícióból adódik: $\sum_{X_{\ell} \in N} a_{i \ell} \geq \sum_{X_{\ell} \in N} a_{j \ell}$ esetén $a_{i k}^{\prime}>a_{i k}$ következtében $\sum_{X_{\ell} \in N} a_{i \ell}^{\prime}>\sum_{X_{\ell} \in N} a_{i \ell} \geq \sum_{X_{\ell} \in N} a_{j \ell}>\sum_{X_{\ell} \in N} a_{j \ell}^{\prime}$.

Jelölje $\Delta x_{\ell}(\varepsilon)=x_{\ell}(\varepsilon)\left(N, A^{\prime}, M^{\prime}\right)-x_{\ell}(\varepsilon)(N, A, M)$. Az általánosított sorösszeg módszernél Chebotarev (1994, Property 11) alapján $\Delta x_{i}(\varepsilon)>0, \Delta x_{k}(\varepsilon)<0$, és $\Delta x_{i}(\varepsilon)=\max \left\{\Delta x_{\ell}(\varepsilon): X_{\ell} \in N\right\}$, ami a bizonyítás szerint az egyetlen maximum.

6.2. Lemma. A pontszám és az általánositott sorösszeg módszer teljesíti a CSM tulajdonságot.

Bizonyítás. A 6.1. Lemmából és a 6.1. Következményből adódik.

Az összehasonlítási multigráf összefüggősége csak az $M$ mérkőzésmátrixtól függ, így az $S M$ és a $C S M$ tulajdonságok automatikusan értelmezhetők a legkisebb négyzetek módszerére.

6.1. Állítás. A legkisebb négyzetek módszere nem teljesíti a CSM tulajdonságot.

Bizonyítás. Ellenpéldát adunk $n=3$-ra. 
6.1. ábra. A 6.1. Példa rangsorolási problémái

(a) $\mathrm{Az}(N, A, M)$ rangsorolási probléma

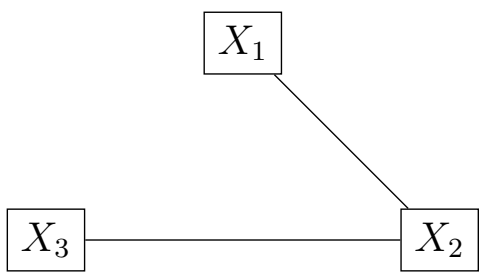

(b) $\mathrm{Az}\left(N, A^{\prime}, M\right)$ rangsorolási probléma

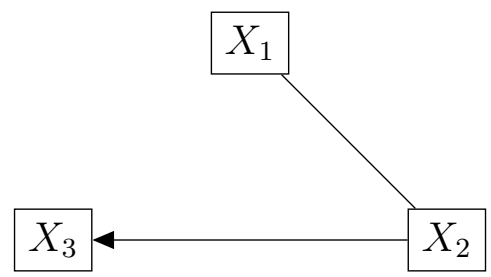

6.1. Példa. Tekintsük az $(N, A, M),\left(N, A^{\prime}, M\right) \in \mathcal{R}_{U}^{3}$ súlyozatlan rangsorolási problémákat (6.1. ábra), ahol:

$$
A=\left[\begin{array}{lll}
0 & 0 & 0 \\
0 & 0 & 0 \\
0 & 0 & 0
\end{array}\right], \quad A^{\prime}=\left[\begin{array}{ccc}
0 & 0 & 0 \\
0 & 0 & 1 \\
0 & -1 & 0
\end{array}\right], \quad \text { és } \quad M=\left[\begin{array}{lll}
0 & 1 & 0 \\
1 & 0 & 1 \\
0 & 1 & 0
\end{array}\right]
$$

A legkisebb négyzetek módszeréből $\mathbf{q}(N, A, M)=[0,0,0]^{\top}$ és $\mathbf{q}\left(N, A^{\prime}, M\right)=$ $=[1 / 3,1 / 3,-2 / 3]^{\top}$, azaz $X_{1} \sim{ }_{(N, A, M)}^{\mathbf{q}} X_{2}$ és $X_{1} \sim{ }_{\left(N, A^{\prime}, M\right)}^{\mathbf{q}} X_{2}$, miközben $1=a_{23}^{\prime}>$ $>a_{23}=0$.

A következő állítást már González-Díaz et al. (2014, 159-160. o.) is belátta.

\subsection{Lemma. A legkisebb négyzetek módszere nem teljesíti az SM tulajdonságot.}

6.1. Megjegyzés. Chebotarev (1994, Property 11) monotonitás (monotonicity) axiómája sokkal többet követel meg, mint az $S M$ tulajdonság. Legyen az $(N, A, M) \in \mathcal{R}^{n}$ rangsorolási problémára $x_{i}(\varepsilon)(N, A, M) \geq x_{j}(\varepsilon)(N, A, M)$, valamint $\left(N, A^{\prime}, M\right) \in \mathcal{R}^{n}$ egy olyan rangsorolási probléma, ami azonos $(N, A, M)$-mel, de létezik $X_{k} \in N \backslash$ $\backslash\left\{X_{i}, X_{j}\right\}$, hogy $a_{i k}^{\prime}>a_{i k}$. Jelölje az általánosított sorösszeggel kapott értékelővektorok különbségét $\Delta x_{\ell}(\varepsilon)=x_{\ell}(\varepsilon)\left(N, A^{\prime}, M^{\prime}\right)-x_{\ell}(\varepsilon)(N, A, M)$ minden $X_{\ell} \in N$-re. Ekkor

1. $\Delta x_{i}(\varepsilon)>0$ és $\Delta x_{k}(\varepsilon)<0$;

2. $\Delta x_{i}(\varepsilon)=\max \left\{\Delta x_{j}(\varepsilon): X_{j} \in N\right\}$ és $\Delta x_{k}(\varepsilon)=\min \left\{\Delta x_{j}(\varepsilon): X_{j} \in N\right\}$, a bizonyítás alapján mindkettő az egyetlen maximum és minimum;

3. Ha létezik $X_{j}$-ből $X_{i}$-be vezető út, és minden $X_{j}$-ből $X_{k}$-ba vezető út átmegy $X_{i}$-n, akkor $\Delta x_{j}(\varepsilon)>0$. Ha létezik $X_{j}$-böl $X_{k}$-ba vezető út, és minden $X_{j}$-ből $X_{i}$-be vezető út átmegy $X_{k}$-n, akkor $\Delta x_{j}(\varepsilon)<0$.

4. Ha $\Delta x_{j}(\varepsilon)>0$, akkor létezik olyan $X_{j}$-ből $X_{i}$-be vezető út, mely minden objektumának értékelése szigorúan növekszik.

Ha $\Delta x_{j}(\varepsilon)<0$, akkor létezik olyan $X_{j}$-ből $X_{k}$-ba vezetö út, mely minden objektumának értékelése szigorúan csökken. 
5. A $\Delta x_{j}(\varepsilon)$ változás minden $X_{j} \in N$ esetén egyértelmüen meghatározott az $M$ mérkőzésmátrix által, csak az objektumok közötti páros összehasonlítások számától függ, azok eredményétől nem.

A következő tulajdonság hasonlít a skála invarianciához, de ezúttal az eredménymátrix additívan módosul. Ehhez is némi előkészítés szükséges.

6.3. Definíció. Elemi körön elfogadható transzformáció (admissible transformation on an elementary circuit) (Bouyssou, 1992): Legyen $(N, A, M) \in \mathcal{R}^{n}$ egy rangsorolási probléma és $\left(X_{i}=X_{k_{0}}, X_{k_{1}}, \ldots, X_{k_{t}}=X_{i}\right)$ egy kör a hozzá tartozó összehasonlítási multigráfban. Az elemi körön elfogadható transzformáció egy olyan $\left(N, A^{\prime}, M\right) \in \mathcal{R}^{n}$ rangsorolási problémát eredményez, amire $a_{i j}^{\prime}=a_{i j}$ minden $\left(X_{i}, X_{j}\right) \neq\left(X_{k_{\ell}} X_{k_{\ell+1}}\right)$ és $a_{k_{\ell} k_{\ell+1}}^{\prime}=a_{k_{\ell} k_{\ell+1}}+g$ minden $\ell=0,1, \ldots, t-1$ esetén, ahol $g \in \mathbb{R}$ és $a_{k_{\ell} k_{\ell+1}}+$ $+g, a_{k_{\ell+1} k_{\ell}}-g \in\left[-m_{k_{\ell} k_{\ell+1}}, m_{k_{\ell} k_{\ell+1}}\right]$ minden $\ell=0,1, \ldots, t-1$-re.

A $g$ változó értékét azért kell korlátozni, hogy megőrizzük a páros összehasonlítások eredményének - az $R$ aggregált páros összehasonlítási mátrix definíciójából adódó korlátosságát. Bizonyos elemi körökön csak $g=0$ lehetséges.

6.2. Példa. Az 5.1. Példában az $\left(X_{1}, X_{2}, X_{3}, X_{1}\right)$ elemi körön elfogadható transzformációval kapott $\left(N, A^{\prime}, M\right) \in \mathcal{R}^{n}$ rangsorolási problémára $a_{12}^{\prime}=a_{12}+g, a_{23}^{\prime}=a_{23}+g$ és $a_{31}^{\prime}=a_{31}+g$, ha $a_{12}+g=1+g \in[-3,3]=\left[-m_{12}, m_{12}\right], a_{23}+g=-3+g \in$ $\in[-5,5]=\left[-m_{23}, m_{23}\right]$ és $a_{31}+g=g \in[-2,2]=\left[-m_{31}, m_{31}\right]$, azaz $-2 \leq g \leq 2$.

6.4. Definíció. Kör függetlenség (independence of circuits, $I C$ ) (Bouyssou, 1992): Legyen $(N, A, M),\left(N, A^{\prime}, M\right) \in \mathcal{R}^{n}$ két rangsorolási probléma, ahol $\left(N, A^{\prime}, M\right)$ elemi körön végrehajtott elfogadható transzformációval kapható $(N, A, M)$-ből. Egy $f: \mathcal{R}^{n} \rightarrow \mathbb{R}^{n}$ pontozási eljárás kör független, ha $f_{i}(N, A, M) \geq f_{j}(N, A, M) \Leftrightarrow$ $f_{i}\left(N, A^{\prime}, M\right) \geq f_{j}\left(N, A^{\prime}, M\right)$ minden $X_{i}, X_{j} \in N$-re.

A kör függetlenség értelmében az objektumok sorrendje változatlan, amennyiben az eredményeket - a pontozási eljárások értelmezési tartományán, az $R$ halmazon belül maradva - egy kör mentén a $g$ konstanssal módosítjuk.

6.2. Megjegyzés. Speciálisan, a kör függetlenség azt jelenti, hogy a rangsor nem érzékeny a körbeverések irányára. Ha például $m_{i j}=m_{i k}=m_{j k}=1$ és $a_{i j}=a_{j k}=$ $=a_{k i}=1$, azaz $X_{i}$ legyőzte $X_{j}$-t, $X_{j}$ megverte $X_{k}$-t, $X_{k}$ pedig $X_{i}$-t, akkor $g=-2$ az $\left(X_{i}, X_{j}, X_{k}, X_{i}\right)$ elemi körön elfogadható transzformáció. Így $a_{i j}^{\prime}=a_{j k}^{\prime}=a_{k i}^{\prime}=-1$, vagyis az új rangsorolási problémában $X_{j}$ aratott győzelmet $X_{i}, X_{i} X_{k}, X_{k}$ viszont $X_{j}$ felett. Hasonlóan, $g=-1$ esetén az $\left(X_{i}, X_{j}, X_{k}, X_{i}\right)$ kör mentén minden eredmény döntetlen lesz. Az $I C$ axióma szerint egyik módosítás sem hat a sorrendre.

A kör függetlenség - csakúgy, mint a skála invariancia - elsősorban akkor értelmezhető jól, ha a páros összehasonlítások eredménye diszkrét skálán mérhető. A 
labdarúgásban megszokott pontozás (győzelem: 3, döntetlen: 1, vereség: 0) nem teljesíti ezt a feltételt, mert egy csapatok közötti körbeverés minden eredményét döntetlenre változtatva az összes érintett rosszul jár, egy ponttal kevesebbet szerez.

6.4. Lemma. A pontszám, az általánosított sorösszeg, és a legkisebb négyzetek módszere is teljesíti az IC tulajdonságot.

Bizonyítás. A pontszám módszerre lásd Bouyssou (1992, 63. o.). Egy elemi körön elfogadható transzformáció nem módosítja az $A$ eredmény- és az $M$ mérkőzésmátrixot sem.

\subsubsection{Axiomatizáció}

A 6.1.1. alfejezetben bemutatott két tulajdonság képezi a pontszám módszerre vonatkozó egyik karakterizáció alapját. Ez azonban csak a körmérkőzéses rangsorolási problémák $\mathcal{R}_{R}$ osztályán érvényes.

6.2. Állítás. Egy semleges (NEU), erősen monoton (SM) és kör független (IC) $f: \mathcal{R}_{R}^{n} \rightarrow \mathbb{R}^{n}$ pontozási eljárás ekvivalens a pontszám módszerrel.

Bizonyítás. Az 5.3. (NEU), a 6.1. (SM) és a 6.4. (IC) Lemma szerint a pontszám mindhárom axiómát kielégíti.

Bouyssou (1992) olyan irányított gráfokat vizsgál, ahol az $X_{i}$ és $X_{j}$ csúcsok közötti $R_{i j} \in[0,1]$ folyam mutatja a páros összehasonlítás eredményét, hiányzó összehasonlítások pedig nem megengedettek. Ebben a modellben minden, a $N E U$, az $S M$ és az $I C$ feltételeket teljesítő pontozási eljárás ekvivalens a pontszám módszerrel.

Az $a_{i j}:=R_{i j}-R_{j i}$ definícióval ez kölcsönösen egyértelmüen megfeleltethető a mi rangsorolási problémáinknak. Ez még nem az egész $\mathcal{R}_{R}$ halmaz, hiszen $R_{i j}-$ $-R_{j i} \in[-1,1]$, azonban ellenőrizhető, hogy Bouyssou (1992) bizonyítása tetszőleges $R_{i j} \in[0, m]$ esetén érvényes marad.

6.5. Lemma. A körmérközéses rangsorolási problémák $\mathcal{R}_{R}$ halmazán a 6.2. Állításban szereplő három tulajdonság logikailag független.

Bizonyítás. Lásd Bouyssou (1992, 63. o.). Megmutatjuk, hogy közülük bármely kettőt kiválasztva létezik olyan, a pontszám módszertől különböző eljárás, amely ezeket kielégíti, tehát a harmadikat biztosan megsérti:

$1 A N O$ és $S M$ : a pontszám módszer olyan módosítása, ahol a páros összehasonlítás győztese prémiumban részesül, például

$$
X_{i} \succeq{ }_{(N, A, M)} X_{j} \Leftrightarrow \sum_{X_{k} \in N} a_{i k}+\sum_{a_{i k}>0} 1>\sum_{X_{k} \in N} a_{j k}+\sum_{a_{j k}>0} 1
$$


$2 A N O$ és $I C$ : egyenlő módszer;

$3 S M$ és $I C$ : a pontszám módszer olyan módosítása, amikor holtversenynél az alacsonyabb sorszámú objektum végez elörébb, vagyis az $s_{i}=s_{i}(N, A, M)$ minden $X_{i} \in N$-re jelöléssel $X_{i} \succ{ }_{(N, A, M)} X_{j} \Leftrightarrow\left[s_{i}>s_{j}\right.$ vagy $\left.s_{i}=s_{j}, i<j\right]$.

6.3. Állítás. A 6.2. Állítás karakterizációja nem érvényes a kiegyensúlyozott rangsorolási problémák $\mathcal{R}_{B}$ és a súlyozatlan rangsorolási problémák $\mathcal{R}_{U}$ osztályán sem.

Bizonyítás. Az 5.3. (NEU), a 6.1. ( $S M)$ és a 6.4. (IC). Lemma szerint az általánosított sorösszeg mindhárom axiómát teljesíti. Az 5.7. Példa alapján ez a módszer a kiegyensúlyozott és a súlyozatlan rangsorolási problémák halmazán sem ekvivalens a pontszámmal, mert $s_{1}(N, A, M)=s_{2}(N, A, M)$, de $x_{1}(\varepsilon)(N, A, M)>x_{2}(\varepsilon)(N, A, M)$ és $(N, A, M) \in \mathcal{R}_{B}^{n} \cap \mathcal{R}_{U}^{n}$.

6.3. Megjegyzés. A 6.5. Lemma alapján a három tulajdonság az $\mathcal{R}_{B}$ és az $\mathcal{R}_{U}$ halmazokon is független.

A 6.3. Állítás illusztrálja, hogy egy adott halmazon érvényes axiomatizáció egy ennél bővebb értelmezési tartomány esetén nem mindig marad érvényes.

\subsection{Pontozási eljárások a pontszám módszer kiter- jesztéseként}

A 6.2. Állítás szerint három kézenfekvő tulajdonság elfogadásával a pontszám módszer marad az egyetlen lehetséges pontozási eljárás a körmérkőzéses rangsorolási problémák $\mathcal{R}_{R}$ osztályán. Itt a függetlenség az irreleváns mérkőzésektől axióma teljesülésével sem érvelhetünk ellene (González-Díaz et al., 2014). Ezért logikusnak tűnik olyan feltételek megfogalmazása, amelyek ettől eltérő halmazokon is biztosítják a pontszámmal megegyező rangsort.

\subsubsection{Az ismert axiómák}

6.5. Definíció. Pontszám konzisztencia (score consistency, $S C C$ ) (González-Díaz et al., 2014) : Egy $f: \mathcal{R}^{n} \rightarrow \mathbb{R}^{n}$ pontozási eljárás pontszám konzisztens, ha minden $(N, A, M) \in \mathcal{R}_{R}^{n}$ körmérkőzéses rangsorolási probléma esetén ekvivalens a pontszám módszerrel.

Az $S C C$ tulajdonságot teljesítő pontozási eljárás minden körmérkőzéses rangsorolási problémára a pontszám módszerrel azonos rangsort ad. A legkisebb négyzetek 
módszerének számításával foglalkozó 4.1. Megjegyzésben már röviden kitértünk erre a kérdésre. Egy hasonló tulajdonságot Zermelo (1929) úttörő dolgozata is említ, David (1987, Property 3) szintén ilyen követelményt fogalmaz meg.

6.4. Megjegyzés. Az általánosított sorösszegre Chebotarev (1994, Property 3) egy ennél erősebb tulajdonságot ad egyetértés (agreement) néven: egy $(N, A, M) \in$ $\in \mathcal{R}_{R}^{n}$ egy körmérkőzéses rangsorolási problémára $\mathbf{x}(N, A, M)=\mathbf{s}(N, A, M)$. Söt, Chebotarev (1994, Property 4) helyi egyetértés (local agreement) axiómája szerint, ha $r_{i j}^{(p)}$ minden $X_{j} \in N$-re és $p=1,2, \ldots, m$-re ismert, akkor $x_{i}(N, A, M)=s_{i}(N, A, M)$.

A 6.4. Megjegyzés alapján nyilvánvaló, hogy az általánosított sorösszeg pontszám konzisztens.

Ennél általánosabb követelmény is bevezethető.

6.6. Definíció. Gyözelmek homogén kezelése (homogeneous treatment of victories, HTV) (González-Díaz et al., 2014): Legyen $(N, A, M) \in \mathcal{R}^{n}$ egy olyan rangsorolási probléma, amire $m_{i k}=m_{j k}$ tetszőleges $X_{k} \in N \backslash\left\{X_{i}, X_{j}\right\}$ esetén. Egy $f: \mathcal{R}^{n} \rightarrow \mathbb{R}^{n}$ pontozási eljárás homogén módon kezeli a gyözelmeket, ha $f_{i}(N, A, M) \geq f_{j}(N, A, M) \Leftrightarrow s_{i}(N, A, M) \geq s_{j}(N, A, M)$.

A győzelmek homogén kezelése szerint két objektum relatív sorrendjét a pontszám határozza meg, amennyiben ellenfeleik - az esetleges egymás elleni mérkőzéseket leszámítva - azonosak.

6.5. Megjegyzés. A HTV tulajdonságot az ellenfél multihalmaz segítségével is kifejezhetjük: egy ezt kielégítő $f: \mathcal{R}^{n} \rightarrow \mathbb{R}^{n}$ pontozási eljárás alkalmazásakor $O_{i} \backslash\left\{X_{j}\right\}^{m_{i j}}=$ $=O_{j} \backslash\left\{X_{i}\right\}^{m_{i j}}$ mellett $f_{i}(N, A, M) \geq f_{j}(N, A, M) \Leftrightarrow s_{i}(N, A, M) \geq s_{j}(N, A, M)$ minden $X_{i}, X_{j} \in N$-re.

6.3. Példa. Legyen az $(N, A, M) \in \mathcal{R}_{B}^{4} \cap \mathcal{R}_{U}^{4}$ kiegyensúlyozott és súlyozatlan rangsorolási problémára (6.2. ábra):

$$
A=\left[\begin{array}{cccc}
0 & 1 & 1 & 0 \\
-1 & 0 & 0 & 1 \\
-1 & 0 & 0 & 1 \\
0 & -1 & -1 & 0
\end{array}\right] \quad \text { és } \quad M=\left[\begin{array}{llll}
0 & 1 & 1 & 0 \\
1 & 0 & 0 & 1 \\
1 & 0 & 0 & 1 \\
0 & 1 & 1 & 0
\end{array}\right]
$$

A pontszám módszer alapján $\mathbf{s}(N, A, M)=[2,0,0,-2]^{\top}$, tehát az objektumok rangsora $X_{1} \succ\left(X_{2} \sim X_{3}\right) \succ X_{4}$. Itt $m_{12}=m_{42}=1$ és $m_{13}=m_{43}=1$, ezért egy, a $H T V$ tulajdonságot teljesítő pontozási eljárásra $s_{1}(N, A, M)=2>-2=$ $=s_{4}(N, A, M)$ következtében $f_{1}(N, A, M)>f_{4}(N, A, M)$.

A HTV axióma az SCC kiterjesztése (González-Díaz et al., 2014, 155. o.). 
6.2. ábra. A 6.3. Példa rangsorolási problémája

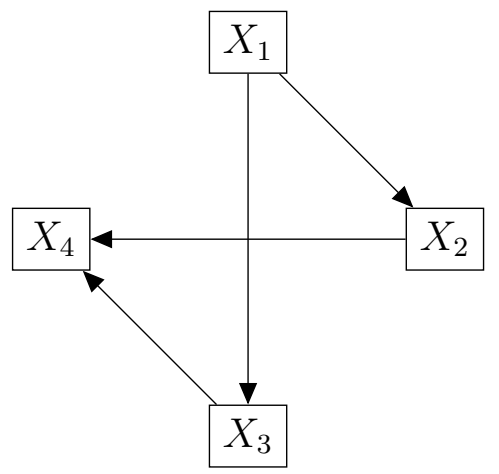

6.2. Következmény. Ha egy $f: \mathcal{R}^{n} \rightarrow \mathbb{R}^{n}$ pontozási eljárás kielégíti a HTV tulajdonságot, akkor az SCC-t is teljesíti.

Bizonyítás. Egy $(N, A, M) \in \mathcal{R}_{R}^{n}$ körmérkőzéses rangsorolási probléma esetén tetszőleges $X_{i}, X_{j} \in N$ objektumokra $m_{i k}=m_{j k}$ minden $X_{k} \in N \backslash\left\{X_{i}, X_{j}\right\}$-re.

6.6. Megjegyzés. Az általánosított sorösszegre Chebotarev (1994, Property 10) egy erösebb tulajdonságot adott dominancia (domination) néven: ha az $X_{i}, X_{j} \in N$ objektumokra $m_{i k}=m_{j k}$ minden $X_{k} \in N \backslash\left\{X_{i}, X_{j}\right\}$ esetén, akkor a $d_{0}=d_{i}=d_{j}$ jelöléssel

$$
x_{i}(N, A, M)-x_{j}(N, A, M)=\frac{1+m n}{1+d_{0}+m_{i j}}\left[s_{i}(N, A, M)-s_{j}(N, A, M)\right] .
$$

\subsection{2. Általánosítás}

Miután az általánosított sorösszeg módszernél tulajdonképpen nem az ellenfél, csak annak értékelése számít, a $H T V$ axióma tovább erősíthető, bár ezt eddig nem tették meg. A megfogalmazáshoz a 6.5. Megjegyzést használjuk.

6.1. Jelölés. Legyen $g: N \leftrightarrow N$ az objektumhalmaz egy kölcsönösen egyértelmü megfeleltetése. Ekkor $\mathfrak{g}:\{1,2, \ldots, n\} \rightarrow\{1,2, \ldots, n\}$, ahol $X_{\mathfrak{g}(k)}=g\left(X_{k}\right)$.

6.7. Definíció. Ellenfelek homogén kezelése (homogeneous treatment of opponents, $H T O)$ : Legyen $(N, A, M) \in \mathcal{R}^{n}$ egy rangsorolási probléma és $f: \mathcal{R}^{n} \rightarrow \mathbb{R}^{n}$ egy pontozási eljárás, amire $X_{i}, X_{j} \in N$ ellenfelei között létezik olyan $g: O_{i} \backslash\left\{X_{j}\right\}^{m_{i j}} \leftrightarrow$ $O_{j} \backslash\left\{X_{i}\right\}^{m_{i j}}$ kölcsönösen egyértelmü megfeleltetés, hogy $f_{k}(N, A, M)=f_{\mathfrak{g}(k)}(N, A, M)$ minden $\left(X_{k}, g\left(X_{k}\right)\right) \in\left(O_{i} \backslash\left\{X_{j}\right\}^{m_{i j}}\right) \times\left(O_{j} \backslash\left\{X_{i}\right\}^{m_{i j}}\right)$-re. $f$ homogén módon kezeli az ellenfeleket, ha $f_{i}(N, A, M) \geq f_{j}(N, A, M) \Leftrightarrow s_{i}(N, A, M) \geq s_{j}(N, A, M)$.

A HTO axióma szerint tehát $f_{i}(N, A, M)$ és $f_{j}(N, A, M)$ relatív nagyságát akkor is a pontszámok határozzák meg, ha az ellenfelek ugyan nem azonosak, de a pontozási eljárás alapján vett értékeléseik igen. A feltétel ellenőrzését megnehezíti, hogy ismernünk kell hozzá a konkrét $f_{k}(N, A, M)$ értékeléseket. A $g$ kölcsönösen egyértelmü 
megfeleltetés miatt $d_{i}=d_{j}$, az axióma csak megegyező számú összehasonlítással rendelkező objektumok esetén jelent megszorítást.

6.4. Példa. Az 5.6. Példában $O_{1}=\left\{X_{2}, X_{6}, X_{7}, X_{8}\right\}, O_{2}=\left\{X_{1}, X_{3}, X_{4}, X_{5}\right\}$ és $s_{1}(N, A, M)=4>2=s_{2}(N, A, M)$. Itt $g: O_{1} \leftrightarrow O_{2}, g\left(X_{6}\right)=X_{3}, g\left(X_{7}\right)=X_{4}$, és $g\left(X_{8}\right)=X_{5}$ egy, a $H T O$ axióma feltételét teljesítő kölcsönösen egyértelmü megfeleltetés, amennyiben $f_{6}(N, A, M)=f_{3}(N, A, M), f_{7}(N, A, M)=f_{4}(N, A, M)$, és $f_{8}(N, A, M)=f_{5}(N, A, M)$. Ekkor $\mathfrak{g}(6)=3, \mathfrak{g}(7)=4$, és $\mathfrak{g}(8)=5$. Ha $f$ az ellenfeleket homogén módon kezelő pontozási eljárás, akkor $f_{1}(N, A, M)>f_{2}(N, A, M)$.

6.3. Következmény. Ha egy $f: \mathcal{R}^{n} \rightarrow \mathbb{R}^{n}$ pontozási eljárás kielégíti a HTO tulajdonságot, akkor a HTV-t (következésképp SCC-t) is teljesíti.

Bizonyítás. Legyen $(N, A, M) \in \mathcal{R}^{n}$ egy rangsorolási probléma, ahol az $X_{i}, X_{j} \in N$ objektumokra $m_{i k}=m_{j k}$ tetszőleges $X_{k} \in N \backslash\left\{X_{i}, X_{j}\right\}$ esetén. Ekkor $g\left(X_{k}\right)=$ $=X_{k}$ egy $O_{i} \backslash\left\{X_{j}\right\}^{m_{i j}} \leftrightarrow O_{j} \backslash\left\{X_{i}\right\}^{m_{i j}}$ kölcsönösen egyértelmü megfeleltetés, amire $f_{k}(N, A, M)=f_{\mathfrak{g}(k)}(N, A, M)$ minden $\left(X_{k}, g\left(X_{k}\right)\right) \in O_{i} \backslash\left\{X_{j}\right\}^{m_{i j}} \times O_{j} \backslash\left\{X_{i}\right\}^{m_{i j}}$ esetén, azaz $f_{i}(N, A, M) \geq f_{j}(N, A, M) \Leftrightarrow s_{i}(N, A, M) \geq s_{j}(N, A, M)$.

6.4. Állítás. A pontszám, az általánosított sorösszeg, és a legkisebb négyzetek módszere is teljesíti a HTO tulajdonságot.

Bizonyítás. A pontszám módszerre az állítás a definícióból következik.

Jelölje $x_{i}$ az általánosított sorösszeg, $s_{i}$ pedig a pontszám módszer alkalmazásával kapott értékeléseket az $(N, A, M)$ rangsorolási problémában. Tekintsük az $X_{i}, X_{j} \in$ $\in N$, a ellenfelek homogén kezelésében szereplő feltételt kielégítő objektumokra vonatkozó egyenletek különbségét:

$$
\begin{aligned}
(1+\varepsilon m n)\left(s_{i}-s_{j}\right)= & {\left[1+\varepsilon\left(\left|O_{i} \backslash\left\{X_{j}\right\}^{m_{i j}}\right|+2 m_{i j}\right)\right]\left(x_{i}-x_{j}\right)+} \\
& +\varepsilon\left[\sum_{X_{k} \in O_{i} \backslash\left\{X_{j}\right\}^{m_{i j}}}\left(x_{\mathfrak{g}(k)}-x_{k}\right)\right]= \\
= & {\left[1+\varepsilon\left(\left|O_{i} \backslash\left\{X_{j}\right\}^{m_{i j}}\right|+2 m_{i j}\right)\right]\left(x_{i}-x_{j}\right) . }
\end{aligned}
$$

Itt $\left|O_{i} \backslash\left\{X_{j}\right\}^{m_{i j}}\right|+2 m_{i j}=d_{i}+m_{i j} \geq 0$, ezért $x_{i} \geq x_{j} \Leftrightarrow s_{i} \geq s_{j}$.

A legkisebb négyzetek módszerére - a megfelelő módosításokkal - ugyanez a gondolatmenet alkalmazható, $d_{i}+m_{i j}=0$ nem lehetséges a rangsorolási probléma feltételezett összefüggősége miatt.

6.7. Megjegyzés. A 6.4. Állítás bizonyítása alapján az ekvivalencia elhagyásával egy, a HTO-nál általánosabb feltétel is megfogalmazható az általánosított sorösszeg és a legkisebb négyzetek módszerekre:

Legyen $(N, A, M) \in \mathcal{R}^{n}$ egy rangsorolási probléma és $f: \mathcal{R}^{n} \rightarrow \mathbb{R}^{n}$ egy pontozási 
eljárás, amire $X_{i}, X_{j} \in N$ ellenfelei között létezik olyan $g: O_{i} \backslash\left\{X_{j}\right\}^{m_{i j}} \leftrightarrow O_{j} \backslash$ $\backslash\left\{X_{i}\right\}^{m_{i j}}$ kölcsönösen egyértelmü megfeleltetés, hogy $f_{k}(N, A, M) \geq f_{\mathfrak{g}(k)}(N, A, M)$ minden $\left(X_{k}, g\left(X_{k}\right)\right) \in\left(O_{i} \backslash\left\{X_{j}\right\}^{m_{i j}}\right) \times\left(O_{j} \backslash\left\{X_{i}\right\}^{m_{i j}}\right)$-re. Ekkor $s_{i}(N, A, M) \geq$ $\geq s_{j}(N, A, M) \Rightarrow f_{i}(N, A, M) \geq f_{j}(N, A, M)$, sőt, $f_{i}(N, A, M)>f_{j}(N, A, M)$, amennyiben bármelyik egyenlőtlenség szigorú formában $(>)$ teljesül.

A feltétel megnevezésétől és további vizsgálatától eltekintünk, csupán annyit jegyzünk meg, hogy ez egyben az önkonzisztencia (self-consistency) (Chebotarev és Shamis, 1997; Csató, 2013b) tulajdonság egy lehetséges általánosítása.

6.8. Megjegyzés. A legkisebb négyzetek módszerére $H T V$ a 6.6. Megjegyzésben jelzett módon tovább erősíthető: ha az $X_{i}, X_{j} \in N$ objektumokra $m_{i k}=m_{j k}$ tetszőleges $X_{k} \in N \backslash\left\{X_{i}, X_{j}\right\}$ esetén, akkor a $d_{0}=d_{i}=d_{j}$ jelöléssel

$$
q_{i}(N, A, M)-q_{j}(N, A, M)=\frac{s_{i}(N, A, M)-s_{j}(N, A, M)}{d_{0}+m_{i j}} .
$$

Érdemes összegyűjteni az ellenfelek homogén kezelésének következményeit.

6.6. Lemma. A pontszám, általánositott sorösszeg, és a legkisebb négyzetek módszere is teljesíti az SCC és HTV tulajdonságokat.

Bizonyítás. A 6.4. Állításból és a 6.3. Következményből adódik.

Az általánosított sorösszeghez lásd a 6.6. Megjegyzést, illetve González-Díaz et al. (2014, Proposition 5.4)-et, a legkisebb négyzetek módszeréhez González-Díaz et al. (2014, Proposition 5.3)-at.

6.7. Lemma. Az általánosított sorösszeg a körmérközéses rangsorolási problémák $\mathcal{R}_{R}$ halmazán teljesíti a HOM és az RCS tulajdonságokat.

Bizonyítás. Az 5.5. (HOM), az 5.9. (RCS), és a 6.6. Lemmából adódik.

6.8. Lemma. Az általánosított sorösszeg és a legkisebb négyzetek módszere a körmérközéses rangsorolási problémák $\mathcal{R}_{R}$ halmazán teljesíti a CS, az IIR és az IIM tulajdonságokat.

Bizonyítás. Az 5.7. (CS), és az 5.14. (IIR) Lemmából, az 5.10. (IIM) Állításból, illetve a 6.6. Lemmából adódik.

6.9. Lemma. A legkisebb négyzetek módszere a körmérkőzéses rangsorolási problémák $\mathcal{R}_{R}$ halmazán teljesiti az SM és a CSM tulajdonságokat.

Bizonyítás. A 6.1. (SM), a 6.2. (CSM), és a 6.6. Lemmából adódik.

A következő példa az eddigiektől eltérő megvilágításba helyezi az általánosított sorösszeg és a legkisebb négyzetek módszere pontszám eljárással való kapcsolatát. 
6.3. ábra. A 6.5. Példa rangsorolási problémája

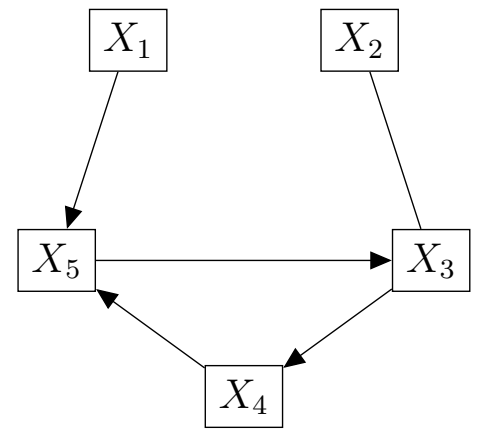

6.5. Példa. (Chebotarev, 1994, Example 2) Legyen az $(N, A, M) \in \mathcal{R}_{U}^{5}$ súlyozatlan rangsorolási problémára (6.3. ábra) :

$$
A=\left[\begin{array}{ccccc}
0 & 0 & 0 & 0 & 1 \\
0 & 0 & 0 & 0 & 0 \\
0 & 0 & 0 & 1 & -1 \\
0 & 0 & -1 & 0 & 1 \\
-1 & 0 & 1 & -1 & 0
\end{array}\right] \quad \text { és } \quad M=\left[\begin{array}{ccccc}
0 & 0 & 0 & 0 & 1 \\
0 & 0 & 1 & 0 & 0 \\
0 & 1 & 0 & 1 & 1 \\
0 & 0 & 1 & 0 & 1 \\
1 & 0 & 1 & 1 & 0
\end{array}\right]
$$

Az általánosított sorösszeg módszerrel az $\varepsilon$ paraméter különböző értékei mellett kapott értékelések a 6.4. ábrán láthatók. Most $m=1$ és $n=5$, ezért $\bar{\varepsilon}=1 / 3 \mathrm{az}$ észszerü felső határ (a 6.4. ábrán függőleges vonallal jelölve).

Az általánosított sorösszeg esetén az objektumok rangsora mindig $X_{1} \succ X_{2} \succ$ $\succ X_{3} \succ X_{4} \succ X_{5}$, ugyanis $X_{1}$,dominálja" $X_{5}$-öt, ami az $X_{3}, X_{4}$ és $X_{5}$ közötti körbeverésen keresztül az előbbi kettőre is kihat. Viszont $X_{3}$-nak van egy döntetlen összehasonlítása $X_{2}$ ellen, ez felelős az $X_{4}$ feletti fölényéért: $X_{2}$ hiányában $X_{3} \sim$ $\sim X_{4}$, mert az $I C$ axióma szerint a körbeverés döntetlenekkel helyettesíthetö, majd alkalmazható a $H T V$ tulajdonság. $X_{2}$ helyezkedik el „legmesszebb” $X_{5}$-től, ez indokolja második helyezését. Az $\mathbf{x}(\varepsilon)$ vektorral adott értékelések nem monotonok, $x_{5}(\varepsilon)$ deriváltja előjelet vált a $(0, \infty)$ intervallumon. ${ }^{21}$

Ez az összefüggés azonban a pontszám és a legkisebb négyzetek módszere esetén sem érvényes, mindkettőnél $X_{3} \sim X_{4} \sim X_{5}$, mintha mellőznék az $\left(X_{2}, X_{3}\right)$ összehasonlítást. Ennek természetesen különböző okai vannak, az előbbinél az ellenfelek teljes figyelmen kívül hagyása, utóbbinál pedig azok maximális szerepe, ami egyúttal az $X_{2} \sim X_{3}$ holtversenyhez vezet.

A 6.5. Példa szerint a gráf interpretáció két szélsősége bizonyos közös vonatkozásokkal is bír, ahogy azt a HOM és az RCS tulajdonságok kapcsán már láttuk.

${ }^{21}$ Chebotarev (1994, Example 2) véleményünk szerint hibásan határozta meg x(4/5) értékét. 
6.4. ábra. A 6.5. Példa $\mathbf{x}(\varepsilon)$ értékelővektorai

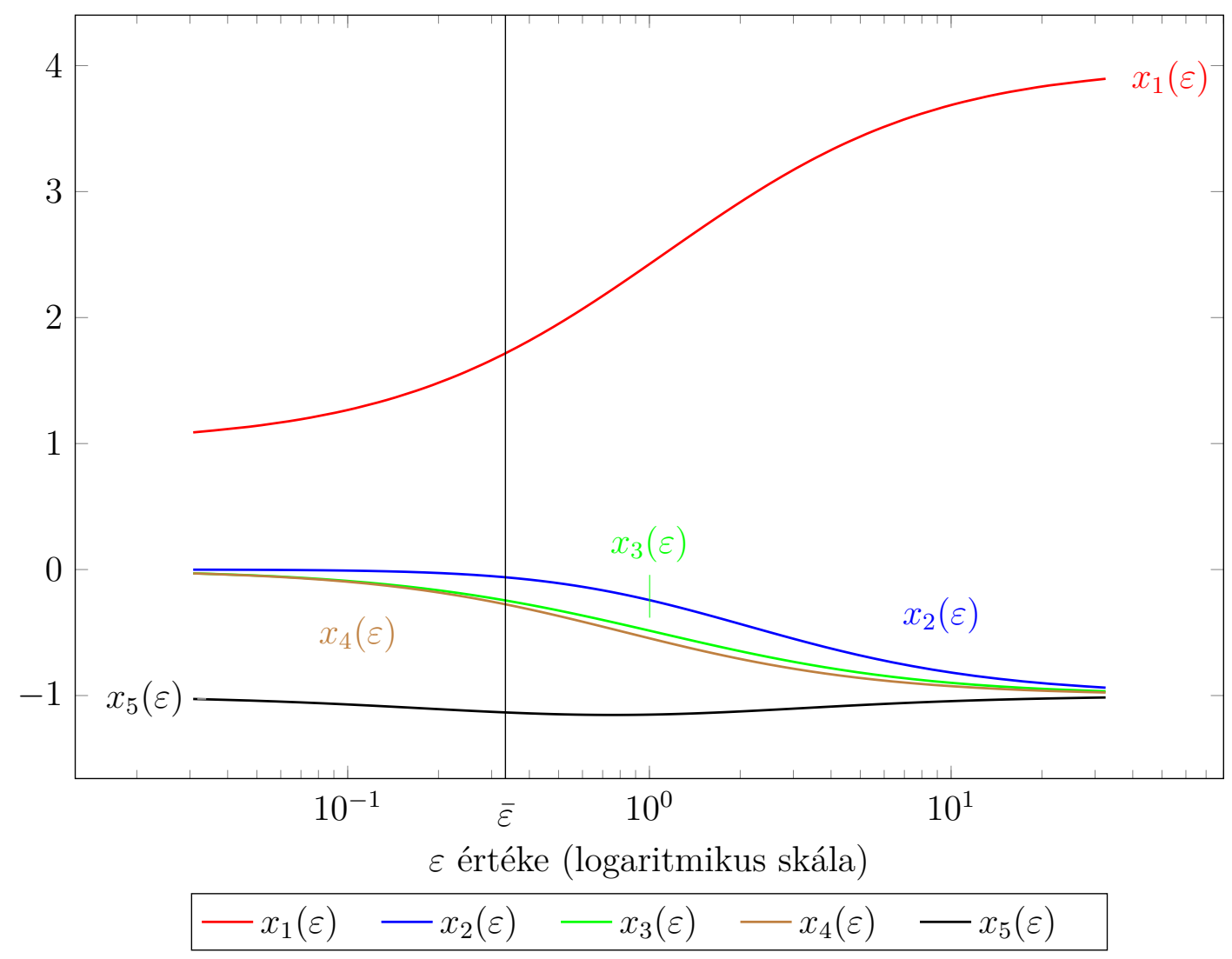

\section{3. Összegzés}

A 6.1. alfejezetben a pontszám módszer egy karakterizációját (Bouyssou, 1992) ismertettük. Ehhez szükségünk volt két új tulajdonság, az erős monotonitás és a kör függetlenség bevezetésére (6.1.1. szakasz). Előbbit a pontszám és az általánosított sorösszeg, utóbbit mindhárom módszer teljesíti. Ezek mellett a 6.2. Állításban csak a természetesnek tekinthető $N E U$ axióma szerepelt. Beláttuk a három tulajdonság logikai függetlenségét, és azt, hogy az axiomatizáció a kiegyensúlyozott vagy a súlyozatlan rangsorolási problémák halmazán már nem érvényes (6.1.2. szakasz).

A 6.2. alfejezetben a pontszám módszerrel való kapcsolatot tárgyaltuk. GonzálezDíaz et al. (2014) nyomán bevezettünk két ismert axiómát, a pontszám konzisztenciát és a győzelmek homogén kezelését (6.2.1. rész). Többé-kevésbé mindkettő szerepelt már Chebotarev (1994) munkájában is. A 6.2.2. szakaszban ezeket az ellenfelek teljesítménye segítségével terjesztettük ki. A HTO még mindig viszonylag korlátozott tulajdonság, csak azonos fokszámú objektumok relatív viszonyáról ad információt, így elsősorban a kiegyensúlyozott rangsorolási problémák $\mathcal{R}_{B}$ halmazán használható. Végül a 6.5. Példán keresztül világítottunk rá a vizsgált módszerek kapcsolatának egy furcsa, látszólag a gráf interpretációnak ellentmondó vonására.

A fejezetben saját eredménynek tekinthető Bouyssou (1992) axiomatizációja 
érvénytelenségének belátása az általános esetben, az $\mathcal{R}$ halmazon (6.3. Állítás), illetve a HTO tulajdonság bevezetése és kielégítésének bizonyítása (6.4. Állítás). Bouyssou (1992) karakterizációja mintha kívül maradt volna a témával foglalkozó irodalom fóáramán, például González-Díaz et al. (2014) sem tesz említést róla. Ennek megfelelően a cikkekben viszonylag ritkán jelenik meg az IC tulajdonság, pedig a 6.2. Megjegyzés szerint a gyakorlati alkalmazások szempontjából komoly jelentősége lehet. Ugyanez elmondható a $H T V$ és HTO axiómákról is.

Befejezésül érdemes kitérni a többi ismert karakterizációra. González-Díaz et al. (2014) - Slutzki és Volij (2005) axiomatizációja alapján - megmutatja, hogy a 2.4. alfejezetben említett fair bets az egyetlen olyan $f: \mathcal{R}^{n} \rightarrow \mathbb{R}^{n}$ pontozási eljárás, ami az ANO, HOM, FP és SYM axiómák mellett a negatív reakció a vereségekre (negative response to losses, $N R L)$ tulajdonságot is teljesíti. Az első négyet a pontszám és a legkisebb négyzetek módszere szintén kielégíti, tehát az $N R L$ axióma valóban kulcsszerepet játszik a karakterizációban.

Ez a tulajdonság azonban szubjektív értékítéletet hordoz magában, ezért pozitív megközelítésben könnyen támadható (Csató, 2013d, 2014b). A fair bets módszer másik hátránya, hogy (a jobb- és baloldali sajátvektor potenciális különbözősége miatt) nem megfordítható, a páros összehasonlítások eredményeinek ellenkezőjére változtatása nem feltétlenül fordítja meg az objektumok rangsorát. Ezek alapján Slutzki és Volij (2005), illetve Slutzki és Volij (2006) fair bets és invariáns módszerekre vonatkozó karakterizációját is vitathatónak tartjuk. Ezekről további részletek olvashatók egy korábbi cikkünkben (Csató, 2013d).

A pontszám módszerre a szavazáselméleti irodalomban adott axiomatizációk (Young, 1974; Hansson és Sahlquist, 1976; Nitzan és Rubinstein, 1981) modellünkbe illesztése nem tűnik egyszerü feladatnak. Mindenesetre Bouyssou (1992) eredményével szemben mindegyik tartalmazza a konzisztenciát, ezért - hiába bizonyulnak esetleg érvényesnek az egész $\mathcal{R}$ halmazon - az 5.2. Tétel értelmében az IIM axióma teljesülése miatt elvethetjük őket.

Összességében kijelenthető, hogy eddig nem került sor a páros összehasonlítások alapján végzett rangsorolás kérdésének egyértelmű karakterizációkkal történő lezárására. Úgy véljük, tárgyalásunkkal sikerült néhány hasznos, eddig ismeretlen szemponttal gazdagítani a pontozási eljárások elemzését.

Az axiómák eredetét és a velük kapcsolatos eredményeket az F.V. Függelék F.6., összefüggéseiket pedig az F.7. táblázata tartalmazza. 


\section{7. fejezet}

\section{Rangsorolás svájci rendszerü sakk csapatversenyekben}

Man muß das Unmögliche fordern, damit das Mögliche erreicht wird.

Helmuth Karl Bernhard von Moltke gróf

Ebben a fejezetben a vizsgált pontozási eljárások egy alkalmazását mutatjuk be. A páros összehasonlításokon alapuló rangsorolás egyik klasszikus területe a sport: a témával foglalkozó korai művek megszületéséhez több alkalommal sakkversenyek szolgáltatták az inspirációt (Landau, 1895, 1914; Zermelo, 1929). ${ }^{22}$ A következőkben egy ilyen rangsor felállítására teszünk kísérletet a svájci rendszerü sakk csapatversenyek esetén. A kérdést már tárgyaltuk egy korábbi cikkünkben (Csató, 2013a), ezúttal azonban igyekszünk mélyebb, alaposabb módszertani megalapozást adni, és a különböző sorrendek értékelését szintén továbbfejlesztjük. A tárgyalás során tehát nem szakadunk el az axiomatikus megközelítéstől, továbbra is igyekszünk normatív jellegü megállapításokat tenni.

\subsection{Svájci rendszerü sakk csapatversenyek rangso- rolásának modellezése}

A résztvevők teljesítménye számos sportban csak egymáshoz képest, páros összehasonlításokkal értékelhető, ugyanakkor egy versenyen az indulók nagy száma, azok túlterhelésének elkerülése, a mérkőzés költségessége, illetve időhiány miatt nincs lehetőség egy teljes körmérkőzéses bajnokság rendezésére. Erre a problémára például

${ }^{22}$ Edmund Landau második sakkal kapcsolatos írása (Landau, 1914) a Zeitschrift für Mathematik und Physik 63. kötetében jelent meg. A folyóirat rangját jelző tudománytörténeti érdekesség, hogy néhány oldallal hátrébb ugyanitt olvasható Albert Einstein - magyar származású munkatársával, Marcel Grossmannal közös - cikke a gravitációs egyenletek általános kovarianciájáról, az általános relativitáselmélethez vezető út egyik fontos állomása (Einstein és Grossmann, 1914). 
a svájci rendszer (Swiss system) kínál megoldást: a torna előre megadott számú $c$ körig (round) tart, az $n$ játékos között minden fordulóban páros mérkőzéseket rendeznek (a résztvevők páratlan száma jelentette problémákra nem térünk ki). Az alábbiakban az ilyen formában rendezett sakkversenyekkel foglalkozunk.

\subsubsection{Svájci rendszerü sakkversenyek jellemzői}

$\mathrm{Az}$ előbb említett korlátok figyelembevételével valamilyen eljárással bármely n-hez meghatározható egy alkalmas (optimális?) c, bár a szervező ennek kiválasztásakor általában csak a résztvevők hozzávetőleges számát ismeri. A továbbiakban ezt adottságnak tekintjük, ahogy a játékosok számát is.

Svájci rendszerű versenyeknél két további, matematikai szempontból értelmezhető kihívás merül fel: hogyan párosítsuk a játékosokat (az egyes fordulókban kik között rendezzenek mérkőzéseket), illetve miként határozzuk meg a végeredményt, a résztvevők sorrendjét az $c$ forduló lejátszását követően. Az első kérdést nem tárgyaljuk, csak röviden ismertetjük az alkalmazott eljárást. A svájci rendszerü sakkversenyek párosító algoritmusának alapelve, hogy lehetőség szerint azonos múltbeli teljesítményü játékosok mérkőzzenek meg egymással. A torna első fordulójában ez semmitmondó feltétel, így többnyire valamilyen külső információt vesznek figyelembe. Ezt követően a teljesítményt a játékosok pontszámával mérik, a mérkőzéseket azonos (vagy közel azonos) pontszámú csoportokon belül rendezik meg. Emellett arra is figyelni kell, hogy a világos-sötét mintázat megfelelő legyen. A különböző párosító algoritmusokról a nemzetközi sakkszövetség (FIDE, Fédération Internationale des Échecs) szabályzatában olvashatunk (FIDE, 2014), míg Kujansuu et al. (1999) egy stabil párosításon alapuló javaslatot ad a feladatra.

Egy sakkmérkőzés kétféle eredménnyel zárulhat: valamelyik játékos nyer, vagy döntetlen. A győztes többnyire egy, a vesztes nulla pontot kap, míg a döntetlen fél-fél pontot jelent számukra (néhány esetben, a labdarúgáshoz hasonlóan, győzelemért három, döntetlenért egy pont jár).

A rangsorolás szinte mindig egy olyan lexikografikus rendezés, melynek elsődleges szempontja a játékosok pontszáma. Ez még nem elegendő a holtversenyek eldöntésére, mert az $c$ fordulóban legalább 0 és legfeljebb $2 c$, azaz $2 c+1$-féle pontszám szerezhető, így $c<n / 2-1$ esetén az $n$ játékos között garantáltan lesznek azonos pontszámúak. Ekkor különböző holtverseny-eldöntő szabályok (tie-breaking rules) alkalmazása válik szükségessé, lásd például FIDE (2014).

Az érdeklődők körében jól ismert, hogy a svájci rendszerü versenyek végeredményét döntően befolyásolhatja a párosítás: miután a játékosok különböző ellenfelekkel találkoznak, előnybe kerülhet az, aki gyengébb párokat kapott. Ezen probléma kezelésére a fenti elven nyugvó párosító algoritmus és a lexikografikus rendezés teljes 
mértékben nem alkalmas (Csató, 2012a, 2013a; Brozos-Vázquez et al., 2010; Jeremic és Radojicic, 2010). Tekintsünk két, az c forduló lejátszása után azonos pontszámú $X_{i}$ és $X_{j}$ játékost. $X_{i}$ belső körön haladt, amennyiben pontjainak többségét az első körökben szerezte. Ehhez hasonlóan, $X_{j}$ külső körön haladt, ha pontjainak nagy részét az utolsó fordulókban szerezte. Bár egyik sem formális definíció, a külső körös $X_{j}$ játékos feladata könnyebbnek tünik, hiszen a kezdeti szerényebb teljesítmény okán a párosító algoritmus számára gyengébb ellenfeleket ad. Ilyen helyzet akkor is előállhat, amikor $X_{j}$ pontszáma kicsit meghaladja $X_{i}$-ét, ekkor viszont a lexikografikus rendezés alapján $X_{j}$ biztosan elörébb kerül $X_{i}$-nél.

Ez a megállapítás ugyan szigorúan nézve csak akkor igaz, ha a gyengébb és erősebb fogalmak mérésére valóban megfelelő a pontszám (az imént mondottak szerint nem mindig ez a helyzet), a fenti rangsorolási módszer mégis jellemzően a külső körös játékosoknak kedvez. Természetesen lehet érvelni amellett, hogy a fokozatosan javuló teljesítmény többet ér az egyre romlónál, de ekkor a végeredmény olyan szubjektív értékítéletet tartalmaz, ami egy pozitív tudomány számára nehezen elfogadható. Ugyanilyen probléma merül fel egyes pontozási eljárásoknál, például a fair betsnél vagy a pozíciós erőnél (Csató, 2013d).

Csapatversenyek esetén azok tagjai $2 t$, páros számú táblán mérkőznek meg egymással, ${ }^{23}$ így különbséget kell tenni a csapat által elért mérközéspontok (match points) és a csapattagok által szerzett táblapontok ${ }^{24}$ (board points) között. Utóbbiban a játékosok egyes táblákon elért pontszámát először mérkőzésenként, majd fordulónként összegzik. Minden táblán egy, azaz a teljes mérkőzésen $2 t$ táblapont kerül szétosztásra. A mérkőzéspontokat szintén fordulónként számítják, a csapatok mérkőzésének eredményét a táblapontok száma határozza meg:

- kettő, ha az adott mérkőzésen elért táblapontok száma legalább $t+0,5$, vagyis a csapat ellenfelénél többet szerzett;

- egy, ha az adott mérkőzésen elért táblapontok száma $t$, azaz a csapat ellenfelével megegyező számút szerzett;

- nulla, ha az adott mérkőzésen elért táblapontok száma legfeljebb $t-0,5$, tehát a csapat ellenfelénél kevesebbet szerzett.

A lexikografikus rendezés fő szempontjaként szinte kizárólag ezek valamelyike szolgál. Az utóbbi időben talán elterjedtebb a mérkőzésponton alapuló rangsorolás, ezt használják a sakkolimpián és a csapat Európa-bajnokságon is.

${ }^{23}$ Általában minden csapatnak elöre meg kell határoznia, hogy a $2 t$ csapattag közül ki melyik (hányas számú) táblán játsszon. A mérkőzéseken az azonos sorszámú táblán játszók kerülnek szembe egymással. Lehet néhány tartalék játékos is, akik tetszőleges táblán helyettesíthetik a többieket.

${ }^{24}$ Ezt több helyen játékpont (game point) néven említik. 


\subsubsection{A sorrend meghatározása pontozási eljárásokkal}

Mivel $c<n-1$, a résztvevők nem mérkőznek meg minden lehetséges ellenfelükkel, ugyanakkor a párosítás kizárja, hogy két szereplő egynél többször játsszon egymás ellen. Így modellünkben egy olyan $(N, A, M) \in \mathcal{R}_{U}^{n}$ súlyozatlan rangsorolási problémáról beszélhetünk, ahol az $N$ objektumhalmaz a játékosok, az $M$ mérkőzésmátrix pedig a párosítás által adott: $m_{i j}=1$ akkor és csak akkor, ha $X_{i} \in N$ és $X_{j} \in N$ játszott egymással, különben $m_{i j}=0 .{ }^{25}$

Az előző fejezetek alapján a végeredmény meghatározására, a játékosok sorrendjének kialakítására akár pontozási eljárások is alkalmazhatók, amihez a fentiek szerint csak a rangsorolási probléma $A$ eredménymátrixát kell megadni. Ez egyéni versenyek esetén megnyugtató módon nem lehetséges, mert világos előnyben van sötéttel szemben, a páros összehasonlítások kimenetele nem szimmetrikus, ez viszont modellünkben nem megengedett. Ugyan vannak olyan egyéni versenyek, ahol a mérkőzéseket mindkét színkiosztással lejátsszák, de ezek jellemzően körmérkőzéses tornák. Csapatversenyeknél azonban a két csapat mérkőzését azok tagjai 2t, páros számú táblán játsszák le, egy fordulóban ugyanannyian játsszanak világossal, mint sötéttel. Ekkor többé-kevésbé elfogadható feltevésnek tünik az, hogy a színkiosztásnak nincs jelentősége, ezért a továbbiakban sakk csapatversenyekkel foglalkozunk.

7.1. Jelölés. mp és gp a mérkőzés- és táblapontok vektora. $c \leq n-1$ a svájci rendszernek megfelelően lejátszott fordulók száma. $2 t$ az egy mérkőzésen játszó csapattagok száma.

Az mp és bp vektorokból a 2.11. Megjegyzés alapján kapott sorrendek megegyeznek a gyakorlatban használt lexikografikus rendezésen alapuló rangsorokkal, kivéve, hogy a holtversenyeket nem döntik el.

A mérkőzés- és táblapontok megkülönböztetése miatt először két eljárást javasolunk az $A$ eredménymátrix meghatározására, majd közös keretbe helyezzük azokat. $m_{i j}=0$-ra nem szükséges definiálni az eredménymátrix megfelelő $a_{i j}$ elemét, mert a 2.2. Megjegyzés szerint ekkor $a_{i j}=0$.

7.2. Jelölés. $M P_{i j}$, illetve $B P_{i j}$ az $X_{i} \in N$ csapat által az $X_{j} \in N$ csapat elleni mérkőzésen elért mérkőzés-, illetve táblapontok száma.

7.1. Definíció. Mérközéspont alapú eredménymátrix (match points based results

${ }^{25}$ Az egyes fordulók megkülönböztetését indokolatlannak tartjuk, bár - fóleg előrejelzési szempontból - lehetne a későbbiek nagyobb jelentősége mellett érvelni. A Formula-1 autóversenyek esetén 2013-2014 fordulóján élénk vita bontakozott ki arról a normatív szempontból nehezen védhető, elsősorban az érdeklődés fenntartása céljából született javaslatról, hogy az utolsó (vagy az utolsó három) futamon a helyezettek extra díjazásban részesüljenek. Lásd például http: //www . bbc. com/sport/0/formula1/25955560 és http://www.bbc. com/sport/0/formula1/25310466. A szabályzat szerint 2014-ben az utolsó versenyen szerzett pontszámok duplán számítanak (http: //www.formula1.com/inside_f1/rules_and_regulations/sporting_regulations/8681/). 
matrix): $\mathrm{Az}\left(N, A^{M P}, M\right) \in \mathcal{R}^{n}$ rangsorolási probléma eredménymátrixa mérkőzéspont alapú, ha $a_{i j}^{M P}=M P_{i j}-1$ minden $X_{i}, X_{j} \in N$-re.

7.2. Definíció. Táblapont alapú eredménymátrix (board points based results matrix): $\mathrm{Az}\left(N, A^{B P}, M\right) \in \mathcal{R}^{n}$ rangsorolási probléma eredménymátrixa táblapont alapú, ha $a_{i j}^{B P}=\left(B P_{i j}-t\right) / t$ minden $X_{i}, X_{j} \in N$-re.

7.3. Definíció. Általánosított eredménymátrix (generalised results matrix): $\mathrm{Az}$ $\left(N, A^{P}(\lambda), M\right) \in \mathcal{R}^{n}$ rangsorolási probléma eredménymátrixa általánosított, ha $a_{i j}^{P}(\lambda)=(1-\lambda)\left(M P_{i j}-1\right)+\lambda\left(B P_{i j}-t\right) / t$ minden $X_{i}, X_{j} \in N$-re, ahol $\lambda \in(0,1)$ egy paraméter.

Az eredménymátrix mindegyik esetben ferdén szimmetrikus, és $a_{i j} \in\left[-m_{i j}, m_{i j}\right]$ minden $X_{i}, X_{j} \in N$-re, tehát valóban érvényes rangsorolási problémát kapunk.

7.1. Lemma. Az általánosított eredménymátrix határértéke a mérközéspont alapú eredménymátrix, ha $\lambda \rightarrow 0$, azaz $\lim _{\lambda \rightarrow 0} A^{P}(\lambda)=A^{M P}$.

$A z$ általánosított eredménymátrix határértéke a táblapont alapú eredménymátrix, ha $\lambda \rightarrow 1$, azaz $\lim _{\lambda \rightarrow 1} A^{P}(\lambda)=A^{B P}$.

Bizonyítás. A 7.1 és 7.2. Definíció alapján $A^{P}(\lambda)=(1-\lambda) A^{M P}+\lambda A^{B P}$.

7.2. Lemma. $A^{M P}$ esetén a pontszám módszer ekvivalens az $\mathbf{m p}$ mérközéspont vektorral.

Bizonyítás. A résztvevő csapatok páros száma miatt $d_{i}=c$ minden $X_{i} \in N$-re, ezért $\mathbf{s}=\mathbf{m p}-c \mathbf{e}$.

7.3. Lemma. $A^{B P}$ esetén a pontszám módszer ekvivalens a bp táblapont vektorral.

Bizonyítás. A résztvevő csapatok páros száma miatt $d_{i}=c$ minden $X_{i} \in N$-re, ezért $\mathbf{s}=\mathbf{b p}-$ cte.

Ezek alapján kaphatjuk a gyakorlati alkalmazást megalapozó fó eredményünket.

7.1. Tétel. Legyen $(N, A, M) \in \mathcal{R}_{R}^{n}$ egy körmérközéses rangsorolási probléma. Az általánositott sorösszeg és a legkisebb négyzetek módszere $A^{M P}$ esetén a mérközéspontok, míg $A^{B P}$ mellett a táblapontok vektorával azonos rangsort eredményez.

Bizonyítás. Az SCC tulajdonság teljesülése (6.6. Lemma) miatt az általánosított sorösszeg és a legkisebb négyzetek módszere ekvivalens a pontszám módszerrel, így a 7.2. és a 7.3. Lemmából adódik az állítás. 
Eszerint mindkét eljárás tekinthető a hivatalosan használt lexikografikus rendezés olyan kiterjesztésének, mely az ellenfelek figyelembevételével próbálja kezelni a mérkőzések hiányát, az ideálisnak tekinthető körmérkőzéses esetnél kevesebb eredmény ismeretét. Amennyiben a hivatalos szabályzat a mérkőzéspontokat tekinti a sorrend alapjának, nyilván az $A^{M P}$ kódolást célszerü használni. Kis, 0-hoz közeli $\lambda$ értékek mellett az általánosított eredménymátrixból ehhez közeli eredmény kapható, de bizonyos mértékben a táblapontok száma (azaz a győzelem mértéke) is számítani fog. Utóbbi $\lambda$ növekedésével egyre fontosabbá válik, végül az $A^{B P}$ eredménymátrixhoz jutunk, ami a táblapont alapú sorrendet terjeszti ki svájci rendszerü versenyekre.

Az ellenfelek teljesítményének beépítése szimulációs vizsgálatok alapján azzal a gyakorlati előnnyel is jár, hogy nincs szükség a holtversenyeket eldöntő további szabályok alkalmazására.

Szintén komoly jelentőséggel bír az alábbi megállapítás.

7.1. Állítás. Legyen $(N, A, M) \in \mathcal{R}^{n}$ egy rangsorolási probléma és $k \in(0,1]$. Az általánosított sorösszeg és a legkisebb négyzetek módszerével kapott rangsor az $A^{M P}$ és $k A^{M P}$, illetve az $A^{B P}$ és $k A^{B P}$ eredménymátrixok esetén azonos.

Bizonyitás. Az SI tulajdonság teljesüléséből (5.6. Lemma) következik.

A 7.1. Állítás értelmében - az objektumok sorrendje szempontjából - csupán egyetlen mérkőzéspont alapú kódolás létezik, ha elfogadjuk, hogy a győzelem jobb a vereségnél. Ugyanígy, a különböző mérkőzéseken szerzett táblapontok egyenlőségének előírása csak egyetlen eredménymátrixszá való transzformációt tesz lehetővé. A skála függetlenség hiányában bizonytalan lenne, milyen megfeleltetést alkalmazzunk, például a győzelmeket $a_{i j}=0,5$ vagy $a_{i j}=1$ reprezentálja.

A 7.1. Tétel és a 7.1. Állítás alapján a pontozási eljárások közül a pontszámot, az általánosított sorösszeget, és a legkisebb négyzetek módszerét fogjuk alkalmazni. Ugyanakkor érdemes kitérni az 5. és a 6. fejezetben tárgyalt többi tulajdonság jelentésére ebben a kontextusban:

1. ANO és $N E U$ : nem számít a lejátszott fordulók sorrendje és a résztvevők elnevezése;

2. HOM : a fordulók számának és eredményének arányos módosítása nem befolyásolja a sorrendet;

3. $C S$ : a torna részekre bontásakor mindegyikben nem rosszabb csapat a végső rangsorban sem ér el rosszabb helyezést;

4. $R C S$ : nincs jelentősége, mert egy svájci rendszerü verseny nem bontható két részre úgy, hogy azok mérkőzésmátrixa megegyezzen; 
5. SYM : amennyiben minden csapat azonos pontszámmal végzett, nem tudunk köztük különbséget tenni;

6. INV: az összes mérkőzés eredményének megfordításával a rangsor is az ellenkezőjére változik;

7. LOP: a bemutatott ellenpéldák mindegyikében a rangsorolási probléma nagyon kiegyensúlyozatlan (5.5. Példa), vagy a lineáris rendezés szerint jobb objektum ellenfelei sokkal gyengébben teljesítettek egy nála rosszabbénál (5.6. Példa), az utóbbi lehetőséget a pontszámmal való erős korreláció miatt lényegében kizárja a párosító algoritmus alapelve;

8. IIR (és $I I M)$ : hiányzó összehasonlítások jelenlétében az irreleváns eredményektől való függetlenség nem kívánatos;

9. ID: két csapat közötti döntetlen nem befolyásolja relatív sorrendjüket;

10. $S M$ : valamely eredmény javítása növeli az érintett csapat értékelését;

11. IC: az (azonos mértékü) körbeverések iránya, vagy döntetlenekkel való helyettesítése nem befolyásolja a rangsort;

12. HTO: a pontozási eljárás szerint erősebb ellenfelekkel játszó csapat magasabb értékelése esetén pontszáma is nagyobb a másik csapaténál, tehát egy egyértelmüen jobb csapat a lexikografikus rendezés szerint is elörébb végez.

Elsősorban a konzisztencia és a lineáris rendezés megőrzésének hiánya szólhat ellenérvként. A CS tulajdonság nem tűnik komoly problémának, mert nehéz a torna részekre bontása mellett érvelni, bár kétségtelenül érdekes következtetéseket eredményezhet. A lineáris rendezés megőrzésének megsértése a fentiek értelmében kiegyensúlyozott rangsorolási problémát eredményező svájci rendszerü versenyeken valószínűleg nem jelentkezik: sejtésünk szerint a pontszám módszer az $\mathcal{R}_{B}$ halmazon teljesíti az LOP axiómát. A legkisebb négyzetek módszere ugyan nem erősen monoton, de a jobb eredmény elérése biztosan nem ront az adott csapat helyzetén és egy speciális eset kivételével növeli is az értékelését (Csató, 2012b). Az $M$ mérkőzésmátrix fenti definíciója esetén a homogenitás sérülése nem jelent problémát, az általánosított sorösszeg módszer tetszőleges $\varepsilon$ paraméter mellett alkalmazható.

Összességében mind az általánosított sorösszeg, mind a legkisebb négyzetek módszere elfogadhatónak tűnik a svájci rendszerü sakk csapatversenyek végeredményének meghatározására. Legfőbb előnyük, hogy közel állnak a jelenleg elfogadott eljárások koncepciójához, egy lineáris egyenletrendszer megoldásaként számíthatók (akár papíron is, figyelembe véve a 4.2. Tételben az inverz meghatározására adott 
rekurzív formulát ${ }^{26}$ ), és az összehasonlítási multigráf segítségével jól interpretálhatók. Végül a mérkőzés- és táblapontok használatával szemben nem igényelnek kiegészítő szabályokat a holtverseny eldöntésére. Ha két csapat értékelése mégis azonos lenne, érdemes elgondolkodni ennek megörzésén.

\subsection{Alkalmazás: sakkcsapat Európa-bajnokságok}

Az alábbiakban egy konkrét elemzést mutatunk be a svájci rendszerű sakk csapatversenyek 7.1. alfejezetben ismertetett modellezése alapján.

\subsubsection{Választott példák és megvalósítás}

A bemutatott módszereket két sakk csapatversenyen keresztül illusztráljuk:

- 18. férfi (open ${ }^{27}$ ) sakkcsapat Európa-bajnokság (EB), 2011. november 3-11., Porto Carras, Görögország.

Honlap: http: //euro2011. chessdom.com/

Versenyszabályzat: ECU (2012)

Eredmények: http://chess-results. com/tnr57856.aspx

- 19. férfi (open) sakkcsapat Európa-bajnokság, 2013. november 7-18., Varsó, Lengyelország.

Honlap: http: //etcc2013.com/

Versenyszabályzat: ECU (2013)

Eredmények: http://chess-results . com/tnr114411.aspx

Mindkét versenyen $n=38$ csapat szerepelt, melyek $2 t=4$ táblán $c=9$ fordulót játszottak egymással. Az eredmények hozzáférhetősége mellett elsősorban ez indokolta kiválasztásukat: az egymás elleni mérkőzésekből adódó összehasonlítási (multi)gráfnak 171 éle van, reguláris, és nem páros. Körmérkőzéses esetben $n(n-1) / 2=703$ eredmény lenne ismert, ennek mintegy a negyede áll rendelkezésre.

A két torna eredményeit, a résztvevő csapatok egymás elleni táblapontszámait az F.III. Függelék F.1. (2011) és F.2. (2013) táblázata tartalmazza. Az összecsapás győztese a legalább 2,5 táblapontot elérő csapat, a 2 döntetlent, ennél kevesebb pedig vereséget jelent. A nem lejátszott mérkőzéseket - jelöli.

A két Európa-bajnokságon a hivatalos végeredményt adó lexikografikus rendezés elsődleges szempontja a mérkőzéspontok száma (TB1). A holtverseny eldöntésére vonatkozó szabályok 2013-ban sorrendben az alábbiak voltak (ECU, 2013):

${ }^{26}$ Ennek konvergenciája a legkisebb négyzetek módszerére ugyan nem biztosított, amikor az összehasonlítási multigráf reguláris páros, de ez szinte lehetetlen, hiszen például kizárja a 3-hosszú körök létezését.

${ }^{27}$ A magyar csapatban mindkét tornán szerepelt Polgár Judit. 
1. TB2: Sonneborn-Berger pontok összege, az ellenfelek - a legkevesebb mérkőzéspontszámú kivételével - mérkőzéspontszáma szorozva az ellenük elért táblapontok számával, majd összeadva;

2. TB3: táblapontok száma;

3. TB4: ellenfelek táblapontjainak összege;

4. TB5: legyőzött ellenfelek táblapontszámai és a döntetlenekhez tartozók táblapontszámai felének összege.

Mindenhol a magasabb pontszám jobb. A fenti jelöléssel 2011-ben a lexikografikus rendezés szempontjai sorrendben $T B 1, T B 3, T B 4$ és $T B 5$ voltak, az ötödik holtverseny eldöntésére szolgáló szabály alkalmazására nem volt szükség (ECU, 2012). Görögországban az első három, Lengyelországban már az első kettő kritérium egyértelmü rangsort, lineáris rendezést adott.

Ahogy láttuk, a TB1 mutató önmagában nem biztosíthatja ezt, mert a kilenc mérkőzésen legfeljebb 18 mérkőzéspont szerezhető, a résztvevők száma viszont 38, a 19 lehetséges érték kétszerese. Miután a második szempont (2011-ben a TB3, két évvel később a T B2) az elért táblapontok számát is figyelembe veszi, a csapatok mindkét tornán ösztönözve voltak ennek növelésére. Ez különösen a közepes teljesítményt nyújtókra igaz, mert a párosító algoritmus sajátosságai miatt ebben a tartományban sűrűsödnek a résztvevők. Egy minden mérkőzését megnyerő csapat ugyan garantáltan az első helyen végez, így szükségtelen táblapontjai növelésére törekednie, de ez a gyakorlatban elég ritkán történik meg, senki sem mehet biztosra. Más sportágakban ez nem feltétlenül igaz: míg egy teniszjátékosnak fontos a mérkőzés mielőbbi befejezése, a labdarúgásban sokszor marginális a gólkülönbség szerepe.

A 2013-as EB eredményeinek eloszlása, a több táblapontszámot elérő csapatok szempontjából, a 7.1. ábrán látható. ${ }^{28}$ Eszerint a minimális arányú győzelmek a legvalószínübbek, míg a $2: 2$ és $3: 1$ táblapontszámú mérkőzések gyakorisága közel azonos. Ennél nagyobb mértékü fölény az összecsapások hatodában alakult ki. A 2011es verseny hasonló képet mutat, bár ezen csak 33 döntetlen született. Utóbbi azért is fontos kérdés lehet, mert a sakkban viszonylag egyszerüen, megegyezéssel elérhető ilyen eredmény, ezért a sikeres szereplésre már esélytelen csapatok körében felmerülhet ilyen irányú törekvés. A verseny előrehaladtával, részben a párosító algoritmus miatt, valóban emelkedett ezek gyakorisága, 2013-ban a nyolcadik forduló 19 mérkőzéséből kilenc döntetlennel végződött. Noha nem tudjuk kizárni a jelenség előfordulását, jobb megoldás hiányában megőrizzük az eredmények változatlan értékelését. ${ }^{29}$

28 A további számítások eredményei kérésre elérhetők a szerzőnél.

${ }^{29}$ Hasonló problémát okozhat, ha egy erősebb csapat az utolsó fordulóban már egy döntetlennel képes elérni az áhított helyezést, így a kockázat minimalizálása érdekében erre vonatkozó ajánlatot tesz ellenfelének. 
7.1. ábra. A 2013-as sakkcsapat EB eredményeinek eloszlása

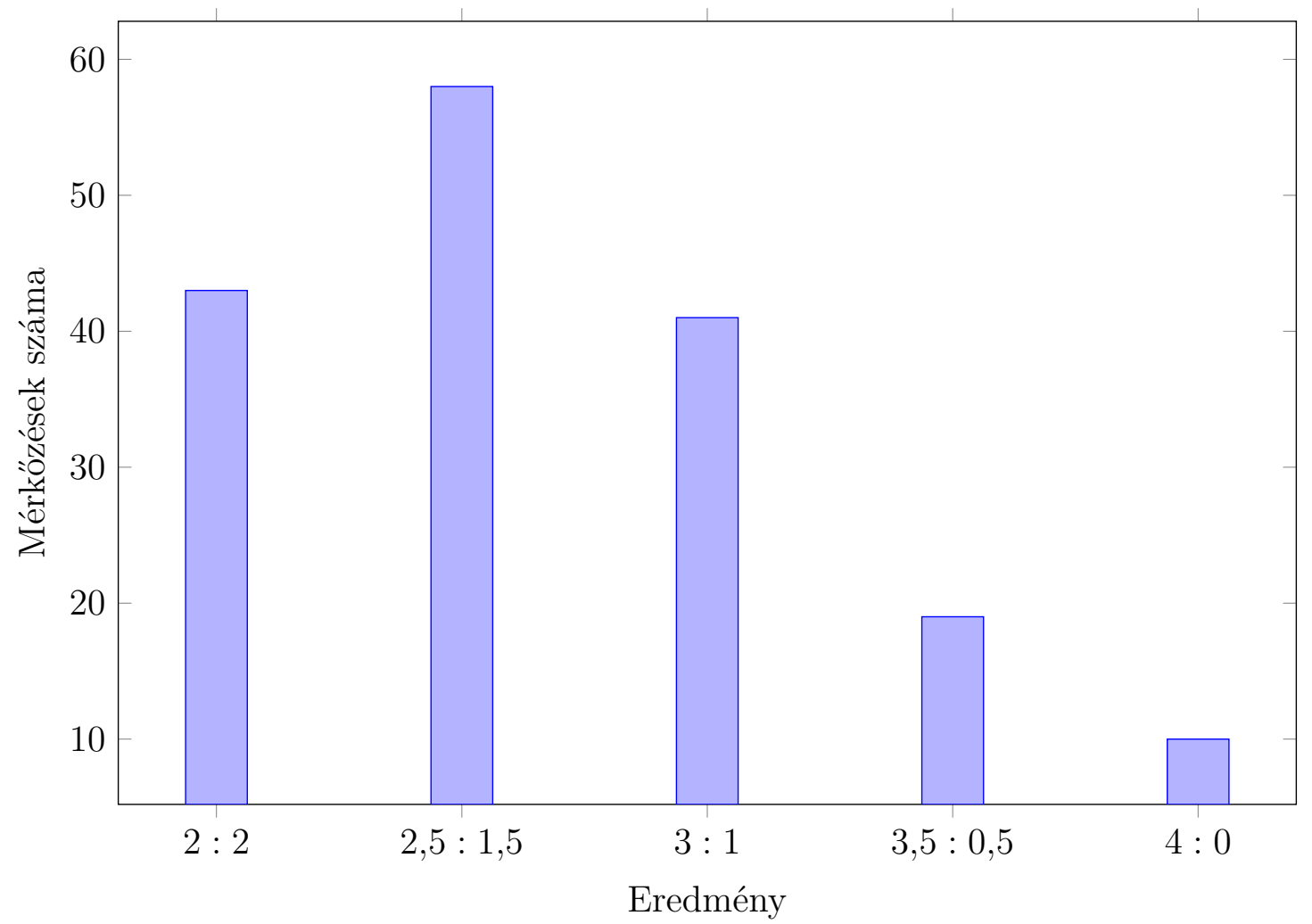

Térjünk rá a rangsorolási probléma megfogalmazására. A csapatok egyaránt érdekeltek a mérkőzéspontok és a táblapontok számának növelésében, ezért az előbbin és az utóbbin alapuló, valamint az általánosított eredménymátrix is használható. Négy különböző lehetőséget vizsgáltunk meg: $A^{M P}, A^{B P}$, illetve $A^{M B}=A^{P}(1 / 4)=$ $=3 / 4 A^{M P}+1 / 4 A^{B P}$ és $A^{B M}=A^{P}(2 / 3)=1 / 3 A^{M P}+2 / 3 A^{B P}$. A $\lambda$ paraméter $(0,1)$ intervallumon nem szimmetrikus eloszlása azt a tényt tükrözi, hogy a mérkőzéspontok jelentősége a táblapontokénál nagyobb volt.

A pontozási eljárások tekintetében három lehetőséget vettünk figyelembe, a legkisebb négyzetek módszerén $(L S)$ kívül az általánosított sorösszeget az $\varepsilon_{1}=1 / 324$ $\left(G R S_{1}\right)$ és a $\varepsilon_{2}=1 / 6\left(G R S_{2}\right)$ paraméterértékek mellett. Előbbi az $1 /[k(n-2)]=$ $=1 /[9(38-2)]=1 / 324$, az ellenfelek szerepét meglehetősen alacsonynak minősítő, észszerü felső határ. $\varepsilon_{2}$ meghatározásánál egyrészt arra figyeltünk, hogy lényegesen különbözzön az előbbiből származó rangsorral, másrészt a 4.3. Tétel szerint az általánosított Buchholz eljárás megfelelő változója $\delta=1 / \varepsilon_{2}+\mathfrak{d}=6+9=15$, ami az $\varepsilon_{1}$-ből adódónál jóval közelebb áll a legkisebb négyzetek módszeréhez. A pontszám módszer alkalmazásától eltekintettünk, hiszen a mérkőzéspontok vektora a holtversenyek eldöntését leszámítva a hivatalos sorrendet adja, a táblapontok számának figyelembevételét pedig indokolatlannak tartottuk.

A legkisebb négyzetek módszerének egyértelmüségéhez szükséges a $G$ multigráf összefüggő volta (3.4. Állítás), ami mindkét alkalommal a harmadik fordulót követően 
állt elő. Ez szinte a legkedvezőbb eset, hiszen két fordulóban csak 38 mérkőzést játszanak, és az összefüggőséghez minimálisan 37 él szükséges. Az eredmény a párosító algoritmus alapelvének köszönhető. Vagyis az általánosított sorösszeg és a legkisebb négyzetek módszere - a hivatalos rangsorhoz hasonlóan - a harmadik forduló végétől kezdve folyamatosan alkalmas a csapatok rangsorának meghatározására. A kevés ismert eredmény miatt igazából nem jelent korlátozást, hogy az első két fordulóban ez még nem lehetséges.

A rangsorokat a harmadiktól kezdve minden forduló után meghatároztuk a négy eredménymátrix és a három módszer mellett. Ez körönként 12 sorrendet jelent, amit a hivatalos (Official), és a csapattagok Élő-pontszámából adódó kezdeti, a priori rangsor (Start) egészít ki.

7.3. Jelölés. A 14 rangsort a következőképp jelöljük: Start, Official; $G R S_{1}\left(A^{M P}\right)$, $G R S_{2}\left(A^{M P}\right), \quad L S\left(A^{M P}\right) ; G R S_{1}\left(A^{M B}\right), \quad G R S_{2}\left(A^{M B}\right), \quad L S\left(A^{M B}\right) ; G R S_{1}\left(A^{B M}\right)$, $G R S_{2}\left(A^{B M}\right), L S\left(A^{B M}\right)$; és $G R S_{1}\left(A^{B P}\right), G R S_{2}\left(A^{B P}\right), L S\left(A^{B P}\right)$. Ugyanez az ábrákon sorrendben Start, Off; G1, G2, G3, G4; S1, S2, S3, S4; és L1, L2, L3, L4.

A Start és az Official rangsorok, a szabályzat szerint, egyben lineáris rendezések. Ellenőrizhető, hogy a két példában a többi 12 rangsor is ilyen, $X_{i} \sim X_{j}$ sehol sem fordul elő, így nincs szükség további holtverseny eldöntésére szolgáló szabályok alkalmazására. A két torna különböző módszerekkel kapott rangsorait az F.III. Függelék F.3. (2011) és F.4. (2013) táblázata tartalmazza.

\subsubsection{A rangsorok ábrázolása}

Elemzésünket a végeredmény, a kilencedik forduló után kapott rangsorok különbözőségének mérésével kezdjük, hiszen a 38 elemü rangsorok eltérései önmagában nehezen értékelhetők. Ennek kiszámítására két lehetőséget választottunk, a Keményés a súlyozott távolságokat. Ennek indoklása és a pontos definíciók az F.II. Függelékben olvashatók.

A 2011-es Európa-bajnokság rangsorainak távolságai a 7.1. táblázatban láthatók. Két sorrend $\delta^{K}$ Kemény-távolságának maximuma akkor áll elö, ha az összes objektumpárt fel kell cserélni, azaz $\delta^{K} \leq n(n-1) / 2=703$. Az 1.a. táblázatban minden érték jelentősen elmarad ettől, azok legnagyobbja is csupán 130. A sok adat között aligha fedezhető fel valamilyen törvényszerüség. Az eredményektől független Start rangsor csaknem mindegyiktől messze található. Legtöbb esetben - a táblapontszámból számított $\left(A^{B P}\right)$ sorrendek kivételével - észrevehető az azonos eredménymátrixból $\left(A^{M P}, A^{M B}, A^{B M}\right.$ és $\left.A^{B P}\right)$ vagy módszerrel $\left(G R S_{1}, G R S 2\right.$ és $\left.L S\right)$ kapott rangsorok közötti kapcsolat. A hivatalos végeredmény megegyezik a $G R S_{1}\left(A^{M B}\right)$ rangsorral.

A megfelelő súlyozott távolságokat az 1.b táblázat tartalmazza. Maximuma $n-1=37$, míg a Kemény-távolságé ennek $n / 2=19$-szerese. Két kiválasztott 
7.1. táblázat. A 2011-es sakkcsapat Európa-bajnokság rangsorainak távolsága

(a) Kemény-távolság

\begin{tabular}{|c|c|c|c|c|c|c|c|c|c|c|c|c|c|c|}
\hline & 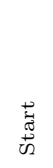 & 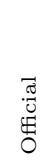 & 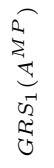 & 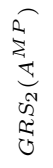 & 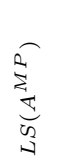 & 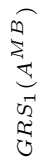 & 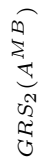 & 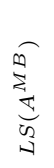 & $\begin{array}{l}\widetilde{1} \\
0 \\
\mathbb{1} \\
= \\
\overrightarrow{2} \\
01 \\
0 \\
0\end{array}$ & 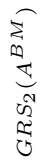 & 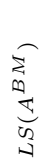 & 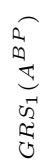 & 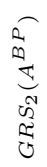 & 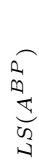 \\
\hline Start & 0 & 107 & 100 & 98 & 100 & 107 & 99 & 96 & 110 & 93 & 93 & 130 & 99 & 85 \\
\hline Official & 107 & 0 & 37 & 45 & 73 & 0 & 38 & 69 & 25 & 34 & 60 & 71 & 52 & 60 \\
\hline$G R S_{1}\left(A^{M P}\right)$ & 100 & 37 & 0 & 16 & 44 & 37 & 13 & 42 & 62 & 31 & 43 & 108 & 61 & 53 \\
\hline$G R S_{2}\left(A^{M P}\right)$ & 98 & 45 & 16 & 0 & 28 & 45 & 7 & 26 & 70 & 27 & 29 & 114 & 67 & 45 \\
\hline$L S\left(A^{M P}\right)$ & 100 & 73 & 44 & 28 & 0 & 73 & 35 & 8 & 94 & 47 & 21 & 130 & 81 & 41 \\
\hline$G R S_{1}\left(A^{M B}\right)$ & 107 & 0 & 37 & 45 & 73 & 0 & 38 & 69 & 25 & 34 & 60 & 71 & 52 & 60 \\
\hline$G R S_{2}\left(A^{M B}\right)$ & 99 & 38 & 13 & 7 & 35 & 38 & 0 & 33 & 63 & 20 & 32 & 107 & 60 & 40 \\
\hline$L S\left(A^{M B}\right)$ & 96 & 69 & 42 & 26 & 8 & 69 & 33 & 0 & 88 & 41 & 13 & 122 & 73 & 33 \\
\hline$G R S_{1}\left(A^{B M}\right)$ & 110 & 25 & 62 & 70 & 94 & 25 & 63 & 88 & 0 & 49 & 79 & 46 & 41 & 71 \\
\hline$G R S_{2}\left(A^{B M}\right)$ & 93 & 34 & 31 & 27 & 47 & 34 & 20 & 41 & 49 & 0 & 30 & 87 & 40 & 26 \\
\hline$L S\left(A^{B M}\right)$ & 93 & 60 & 43 & 29 & 21 & 60 & 32 & 13 & 79 & 30 & 0 & 111 & 60 & 20 \\
\hline$G R S_{1}\left(A^{B P}\right)$ & 130 & 71 & 108 & 114 & 130 & 71 & 107 & 122 & 46 & 87 & 111 & 0 & 57 & 97 \\
\hline$G R S_{2}\left(A^{B P}\right)$ & 99 & 52 & 61 & 67 & 81 & 52 & 60 & 73 & 41 & 40 & 60 & 57 & 0 & 44 \\
\hline$L S\left(A^{B P}\right)$ & 85 & 60 & 53 & 45 & 41 & 60 & 40 & 33 & 71 & 26 & 20 & 97 & 44 & 0 \\
\hline
\end{tabular}

(b) Súlyozott távolság

\begin{tabular}{|c|c|c|c|c|c|c|c|c|c|c|c|c|c|c|}
\hline & $\begin{array}{l}\overrightarrow{ \pm} \\
\text { in } \\
0\end{array}$ & 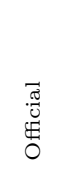 & 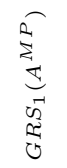 & 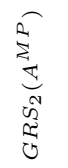 & 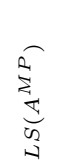 & 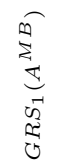 & 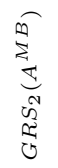 & 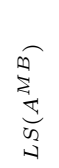 & 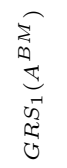 & 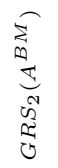 & 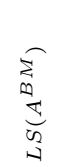 & 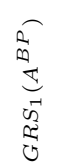 & 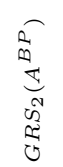 & 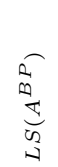 \\
\hline Start & 0 & 10,8 & 9,68 & 9,60 & 9,39 & 10,8 & 9,54 & 9,15 & 11,3 & 9,45 & 8,66 & 12,2 & 10,0 & 8,10 \\
\hline Official & 10,8 & 0 & 3,04 & 3,67 & 6,33 & 0,00 & 3,08 & 6,12 & 2,09 & 2,74 & 5,62 & 6,55 & 4,89 & 5,58 \\
\hline$G R S_{1}\left(A^{M P}\right)$ & 9,68 & 3,04 & 0 & 1,02 & 3,80 & 3,04 & 0,75 & 3,73 & 5,04 & 2,29 & 3,80 & 9,41 & 5,87 & 4,39 \\
\hline$G R S_{2}\left(A^{M P}\right)$ & 9,60 & 3,67 & 1,02 & 0 & 2,80 & 3,67 & 0,60 & 2,73 & 5,66 & 2,24 & 2,87 & 9,97 & 6,36 & 4,15 \\
\hline$L S\left(A^{M P}\right)$ & 9,39 & 6,33 & 3,80 & 2,80 & 0 & 6,33 & 3,39 & 0,53 & 8,07 & 4,36 & 1,53 & 9,94 & 6,20 & 3,01 \\
\hline$G R S_{1}\left(A^{M B}\right)$ & 10,8 & 0,00 & 3,04 & 3,67 & 6,33 & 0 & 3,08 & 6,12 & 2,09 & 2,74 & 5,62 & 6,55 & 4,89 & 5,58 \\
\hline$G R S_{2}\left(A^{M B}\right)$ & 9,54 & 3,08 & 0,75 & 0,60 & 3,39 & 3,08 & 0 & 3,31 & 5,09 & 1,65 & $\begin{array}{l}5,02 \\
3,27\end{array}$ & 9,42 & 5,80 & 3,69 \\
\hline$L S\left(A^{M B}\right)$ & 9,15 & 6,12 & 3,73 & 2,73 & 0,53 & 6,12 & 3,31 & 0 & 7,74 & 4,04 & 1,00 & 9,48 & 5,71 & 2,49 \\
\hline$G R S_{1}\left(A^{B M}\right)$ & 11,3 & 2,09 & 5,04 & 5,66 & 8,07 & 2,09 & 5,09 & 7,74 & 0 & 4,10 & 7,00 & 4,48 & 3,96 & 6,58 \\
\hline$G R S_{2}\left(A^{B M}\right)$ & 9,45 & 2,74 & 2,29 & 2,24 & 4,36 & 2,74 & 1,65 & 4,04 & 4,10 & 0 & 3,29 & 8,01 & 4,23 & 2,98 \\
\hline$L S\left(A^{B M}\right)$ & 8,66 & 5,62 & 3,80 & 2,87 & 1,53 & 5,62 & 3,27 & 1,00 & 7,20 & 3,29 & 0 & 8,79 & 4,79 & 1,49 \\
\hline$G R S_{1}\left(A^{B P}\right)$ & 12,2 & 6,55 & 9,41 & 9,97 & 9,94 & 6,55 & 9,42 & 9,48 & 4,48 & 8,01 & 8,79 & 0 & 4,53 & 7,78 \\
\hline$G R S_{2}\left(A^{B M}\right)$ & 10,0 & 4,89 & 5,87 & 6,36 & 6,20 & 4,89 & 5,80 & 5,71 & 3,96 & 4,23 & 4,79 & 4,53 & 0 & 3,64 \\
\hline$L S_{1}\left(A^{B M}\right)$ & 8,10 & 5,58 & 4,39 & 4,15 & 3,01 & 5,58 & 3,69 & 2,49 & 6,58 & 2,98 & 1,49 & 7,78 & 3,64 & 0 \\
\hline
\end{tabular}

rangsor súlyozott és Kemény-távolságának aránya a 2011-es példában 8,73 és 17,44, a 2013-asban pedig 5,81 és 18,73 között található, tehát az utóbbi esetben a súlyozás valamivel jobban módosítja a távolságokat, a két megközelítés mégis várakozásainknál kevésbé tér el egymástól. Ennek oka (csak) az lehet, hogy a rangsorok eltérései a pozíciók függvényében többé-kevésbé egyenletesen fordulnak elő

A rangsorok távolságának bevezetésével azok összehasonlítása a 13-dimenziós térre redukálható, ahol 14 sorrend tökéletesen ábrázolható. Ez még mindig nehezen elemezhető, azonban lehetséges a dimenziószám további csökkentése, bár ez további információveszteséggel jár. Ehhez Csató (2013a) nyomán a sokdimenziós skálázást (multidimensional scaling, MDS) használtuk (Kruskal és Wish, 1978; Kovács, 2011).

A módszer alapelve, hogy a térben minden megfigyelésnek megfelel egy pont, és a hasonlók közelebb vannak egymáshoz. Az MDS mögött nem áll sztochasztikus modell, nincsenek eloszlásbeli megkötések és tesztelendő hipotézis, nem tételez fel oksági kapcsolatot. Egy klasszikus alkalmazási példa városok légvonalban mért távolságai 
alapján a térképen elfoglalt helyük (tökéletes) visszaadása. A sokdimenziós skálázás bizonyos értelemben hasonló a páros összehasonlítások alapján történő rangsoroláshoz, mindegyiknél egyfajta információtömörítés történik. A kapcsolat feltárása további kutatásokat igényel.

Az MDS módszer az eredeti távolságokat arány, intervallum, vagy ordinális skálán kezeli, esetünkben a legszigorúbb első választás alkalmazható, mert a rangsorok egyezése természetes minimumot jelent. Ekkor a redukált dimenziós térkép $\delta$ diszkrepanciái a $\delta=b d$ lineáris függvénnyel kapcsolódnak az eredeti $d$ távolságokhoz. A leképezés jóságának eldöntésére, a dimenziócsökkentésből származó információveszteség mérésére a Kruskal-féle Stress és az RSQ mutatókat használtuk. Előbbi 0,2-nél nagyobb értéke esetén a dimenziócsökkentés nem elfogadható, míg 0,05 alatt tökéletes illeszkedésről beszélhetünk. A Stress mutató kisebb értéke kedvezőbb, a dimenziószám emelkedése biztosan nem növeli azt. Az RSQ az eredeti távolságban megfigyelhető variancia diszkrepanciák által magyarázott hányada, magasabb értéke kedvezőbb, a dimenziószám emelkedése nem csökkentheti.

A számításokat az SPSS statisztikai programcsomag 20-as verziójával készítettük. ${ }^{30}$ Az illeszkedési mutatók alapján minden esetben elfogadtuk a két-, és elutasítottuk az egydimenziós leképezést. A tengelyeknek nem tulajdonítunk jelentést, irányuknak amúgy sincs jelentősége, a sokdimenziós skálázással kapott eredmények szimmetrikusak azokra (Kovács, 2011). ${ }^{31}$ A pontos koordináták helyett lényegében a kapott pontok egymáshoz való pozíciója számít.

A 7.2. ábra a 2011-es Európa-bajnokságra Kemény-távolsággal kapott skálatérképet mutatja. A 2.a ábra megerősíti az 1.a táblázatból levont következtetéseket, a Start rangsor az összes többitől messze helyezkedik el. Ez jól magyarázható annak eltérő koncepciójával, hiszen a verseny eredményeinek figyelembevétele nélkül készült. A Stress-mutató 0,0995-ös értéke közepes mértékű illeszkedést jelent, az RSQ szerint a redukált skálatérkép az eredeti távolságok varianciájának 96,96 százalékát magyarázza. Az egydimenziós ábra Stress mutatója 0,2802, már nem elfogadható. A teljesen megegyező Official (Off) és $G R S_{1}\left(A^{B P}\right)(\mathrm{G} 1)$ rangsorok skálatérképen elfoglalt pozíciója minimálisan különbözik, ez valószínűleg kerekítési hibák eredménye.

A többi sorrend megbízhatóbb összehasonlítására a Start rangsor kihagyásával megismételtük a számítást. ${ }^{32}$ A 2.b ábra alapján az eredménymátrix függvényében a $G R S_{1}$ módszernél látható a legnagyobb, a $G R S_{2}$ mellett közepes, míg az $L S$ eljárásnál a legkisebb variancia. A táblapontszám $\left(A^{B P}\right.$ eredménymátrix, G4, S4 és L4) segítségével számolt sorrendek jelentősen eltérnek a többitől, különösen az

${ }^{30}$ Az algoritmus lefutásához a szimmetrikus távolságmátrixnak legalább 10 objektumot kell tartalmaznia, részben ez indokolta az eredménymátrix többféle kódolásának használatát.

${ }^{31}$ A 2.a és 2.b ábrákon jól látható a függőleges tengely megfordulása.

${ }^{32}$ A másik három esetben (súlyozott távolság, illetve 2013-ra Kemény- és súlyozott távolság) ez szintén outliernek tekinthetö. 


\section{2. ábra. A 2011-es sakkcsapat EB skálatérképei}

A hivatalos rangsor (Off) megegyezik az egyik általánosított sorösszegből adódóval (G2), ezért távolságuk nulla. A skálatérkép megfelelő koordinátái között minimális eltérés látható, ami minden bizonnyal számítási pontatlanság eredménye.

(a) Kemény-távolság, a Start rangsorral

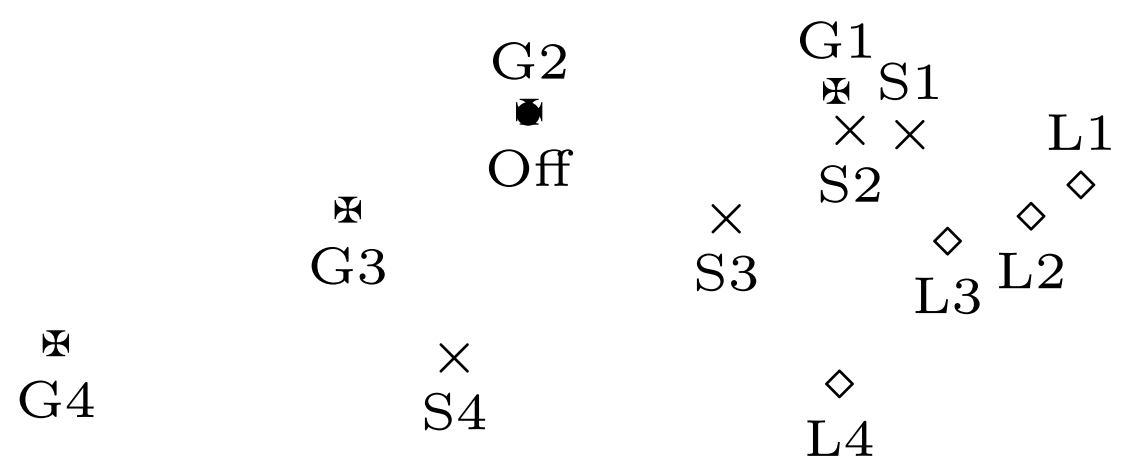

\section{Start}

(b) Kemény-távolság, a Start rangsor nélkül

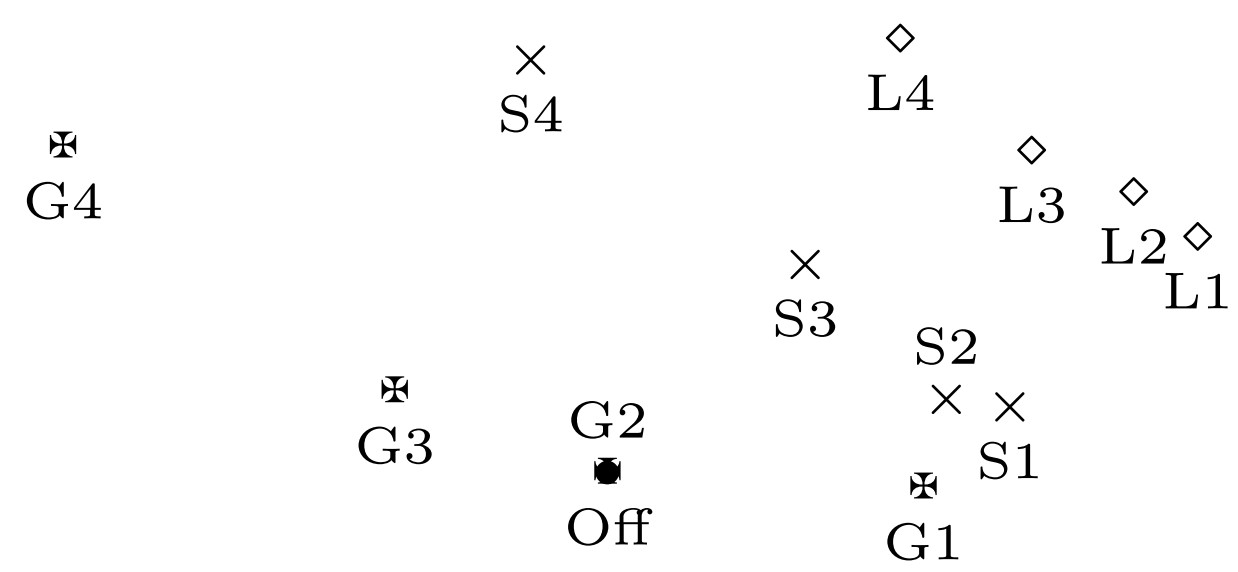

előbbi kettő esetén. A hivataloshoz leginkább a $G R S_{1}$ módszer hasonlít, legkevésbé pedig az $L S$. A rangsorok különbözősége a táblapontszám nagyobb szerepével együtt emelkedik. A skálatérkép a legkisebb négyzetek módszere és a mérkőzéspontok nagyobb jelentősége mellett szól. A Stress-mutató a korábbinál jóval alacsonyabb (0,0264), míg az RSQ értéke 0,9969, mindkettő szinte tökéletes illeszkedést jelez. 
7.3. ábra. A 2013-as sakkcsapat EB skálatérképei

(a) Kemény-távolság, a Start rangsor nélkül

里

G4
G4

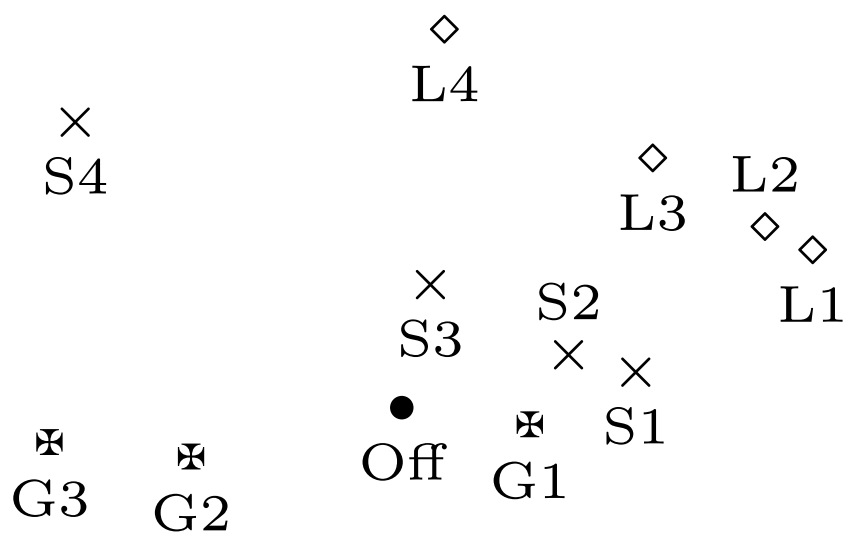

(b) Súlyozott távolság, a Start rangsor nélkül

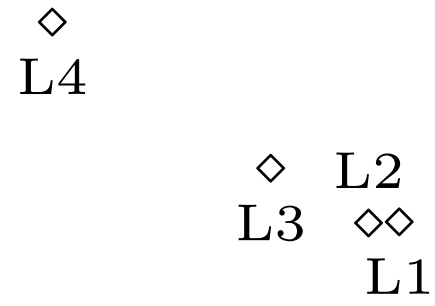

$\mathrm{S} 4$

S3 S2

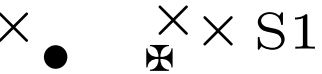

果

G3

Off $\mathrm{G} 1$

A súlyozott távolság használatakor ehhez hasonló ábrákat kapunk, bár a $G R S_{1}$, $G R S_{2}$ és $L S$ módszerek eltérése, valamint az $A^{B P}$ eredménymátrix outlier volta jobban szembetűnő. Ennek illusztrálására a 7.3. ábrán mutatjuk be a 2013-as versenyre a Kemény- és súlyozott távolságok mellett adódó skálatérképeket, mindkét esetben a Start rangsor nélkül. A Stress-mutató értéke 0,0261, illetve 0,0430, a kétdimenziós MDS koordináták az eredeti távolságok varianciájának 99,74, illetve 99,37 százalékát magyarázzák, mindegyik kiváló illeszkedést jelez. Minőségi következtetéseink megegyeznek a 2.b ábrából levontakkal: az $A^{B P}$ eredménymátrix használata, fóként az általánosított sorösszegnél, nehezen indokolható, a legkisebb négyzetek módszere pedig robusztus eredmény ad, de viszonylag messze található a hivatalostól. A Keményés súlyozott távolságok eltérése elhanyagolható, a 2.b és a 3.b ábra lényegében azonos.

A Stress és RSQ mutatók alapján a kétdimenziós illeszkedés mindkét esetben nagymértékben javítható a Start rangsor elhagyásával, a Kemény-távolság a sú- 
lyozottnál jobban magyarázható. Tehát a rangsorok különbözősége a pozíciócserék helyének figyelembevétele nélkül alacsonyabb, ami a dobogón végzett csapatok eltéréseinek köszönhető, hiszen ez a súlyozás bevezetésekor sokkal meghatározóbbá válik a távolság kiszámításában. A skálatérkép némileg elfogadhatóbb a 2013-as versenyre.

\subsubsection{Egy rangsor elemzése}

A rangsorok összevetésére egy másik megközelítést kínál az általánosított sorösszeg és a legkisebb négyzetek módszerének a 4 . fejezetben tárgyalt gráf interpretációja. Mindkét verseny esetén kiegyensúlyozott rangsorolási problémát kapunk, a $G$ összehasonlítási gráf reguláris, de nem páros, ezért - hurokélek hiányában - különösen jól értelmezhető a 4.2. Tétel iteratív felbontása. Ekkor az $A^{M P}$ mérkőzéspont alapú eredménymátrix használata a nulladik lépésben $(k=0)$ a hivatalos rangsort adja vissza attól eltekintve, hogy utóbbiban a holtversenyek is eldöntésre kerültek. Az eljárás az ezt követő lépésekben a $P^{k}$ hatványokon keresztül fokozatosan figyelembe veszi az ellenfelek, majd az ellenfelek ellenfeleinek stb. mérkőzéspontokkal mért erejét, így tükrözni fogja az egyes csapatok sorsolásának nehézségét is.

A 2011-es EB esetén $k=7$, a 2013-asnál pedig $k=12$ esetén kapjuk meg a továbbiakban változatlan, a $\mathbf{q}\left(A^{M P}\right)$ vektor által meghatározott végső sorrendet. Mivel a 4.1. Példában ez csak a 13. lépésben történt meg, úgy tűnik, annak sebességét jobban befolyásolhatja az ismert összehasonlítások szerkezete, mint azok puszta aránya (ahol ez $7 / 21=1 / 3$ volt) vagy az objektumok száma (ott $n=7$ ).

Az $L S\left(A^{M P}\right)$ módszer iteratív felbontásának rangsorváltozásai a 7.2. táblázatban láthatók. A második oszlopban a holtversenyeket a hivatalos rangsornak megfelelön döntöttük el, hogy elkerüljük a rangszámok torlódását (például a 13. helyezett Szerbia és a 18. Montenegró egyaránt 10 mérkőzéspontot szerzett). Mivel különböző mérkőzéspontszámok esetén erre nincs szükség, ez egyúttal azonos a hivatalos rangsorral. Az iteráció későbbi lépéseiben már nem használtunk ilyen szabályokat, mert a $\mathbf{q}^{(k)}\left(A^{M P}\right)$ értékelővektor bármely két koordinátája minden $k \geq 1$-re különböző. $\mathrm{Az}$ egyes iterációs lépésekben a pozíció javulását a $\uparrow$, romlását a $\downarrow$ nyilak jelzik, számuk megegyezik a változás mértékével. Amennyiben ez háromnál több, értéke a megfelelő nyíl mögött zárójelben szerepel. Ennek megfelelően a $\uparrow$ és $\downarrow$ nyilak száma minden oszlopban azonos. A helyezés változatlanságát - jelzi.

A 4.2. Tétel alapján $k=1$ mellett a csapatok mérkőzéspontszámához hozzáadódik ellenfelei pontszámának átlaga, azokat részesítve előnyben, akik nehezebb sorsolással játszották a versenyt. A korrekció legnagyobb nyertese a hét pozíciót javító Szlovénia, vesztese a hat helyezést rontó Hollandia és a néggyel visszaeső Románia. Ezáltal a kilenc mérkőzéspontos Szlovénia megelőzi az ennél kettővel többet szerző Hollandiát. Három helyezéssel több csapat eredménye is változik, ennyit javít Fehéroroszország, 
7.2. táblázat. Pozícióváltozások az $L S\left(A^{M P}\right)$ rangsor közelítésében, 2013

\begin{tabular}{|c|c|c|c|c|c|c|c|c|c|c|c|}
\hline Hatvány & 0 & 1 & 2 & 3 & 4 & 5 & 6 & 8 & 9 & 11 & 12 \\
\hline Anglia & 10 & - & $\uparrow$ & - & - & - & - & - & - & - & - \\
\hline Ausztria & 30 & $\uparrow \uparrow$ & $\uparrow \uparrow$ & - & - & $\uparrow$ & - & - & - & - & - \\
\hline Azerbajdzsán & 1 & - & $\downarrow$ & - & - & - & - & - & - & - & - \\
\hline Belgium & 33 & - & - & $\downarrow$ & - & - & - & - & - & - & - \\
\hline Bulgária & 25 & $\uparrow \uparrow$ & - & - & - & - & - & - & - & - & - \\
\hline Csehország & 8 & $\downarrow$ & $\downarrow$ & - & - & - & - & - & - & - & - \\
\hline Dánia & 27 & $\downarrow \downarrow \downarrow$ & $\downarrow$ & - & - & - & - & - & $\downarrow$ & - & - \\
\hline Fehéroroszo. & 15 & $\uparrow \uparrow \uparrow$ & - & - & - & $\uparrow$ & - & - & - & - & - \\
\hline Finnország & 34 & - & - & $\uparrow$ & - & - & - & - & - & - & - \\
\hline Franciaország & 2 & - & $\uparrow$ & - & - & - & - & - & - & - & - \\
\hline Görögország & 7 & - & - & - & - & - & $\downarrow$ & - & - & - & - \\
\hline Grúzia & 6 & - & - & - & - & - & - & - & - & - & - \\
\hline Hollandia & 11 & $\downarrow(6)$ & - & - & - & - & - & - & - & - & - \\
\hline Horvátország & 17 & $\uparrow \uparrow$ & - & - & $\downarrow$ & - & - & - & - & - & - \\
\hline Izland & 29 & $\downarrow \downarrow \downarrow$ & - & - & - & - & - & - & $\uparrow$ & - & - \\
\hline Izrael & 28 & $\uparrow \uparrow$ & $\uparrow$ & $\uparrow$ & - & - & - & - & - & - & - \\
\hline Lengyelo. $1^{\dagger}$ & 16 & 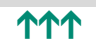 & - & - & - & $\downarrow$ & - & - & - & - & - \\
\hline Lengyelo. $2^{\ddagger}$ & 22 & $\downarrow \downarrow$ & - & $\downarrow$ & - & $\downarrow$ & - & - & - & - & - \\
\hline Lengyelo. $3^{*}$ & 31 & - & $\uparrow$ & - & - & - & $\uparrow$ & - & - & - & - \\
\hline Litvánia & 23 & $\downarrow \downarrow$ & $\downarrow(4)$ & - & - & - & $\downarrow$ & - & - & - & - \\
\hline Macedónia & 37 & - & - & - & - & - & - & - & - & - & - \\
\hline Magyarország & 5 & - & - & - & - & - & - & - & - & - & - \\
\hline Montenegró & 18 & $\downarrow$ & - & $\downarrow$ & - & - & - & - & - & - & $\downarrow$ \\
\hline Németország & 20 & - & - & $\uparrow$ & - & $\uparrow$ & - & - & - & - & - \\
\hline Norvégia & 35 & - & - & - & - & - & - & - & - & - & - \\
\hline Olaszország & 12 & $\uparrow$ & - & - & - & $\downarrow$ & - & - & - & - & - \\
\hline Oroszország & 3 & $\downarrow$ & - & - & - & - & - & - & - & - & - \\
\hline Örményország & 4 & $\uparrow$ & - & - & - & - & - & - & - & - & - \\
\hline Románia & 14 & $\downarrow(4)$ & $\uparrow \uparrow$ & - & $\uparrow$ & - & - & - & - & - & - \\
\hline Skócia & 36 & - & - & - & - & - & - & - & - & - & - \\
\hline Spanyolország & 19 & $\downarrow \downarrow$ & - & - & - & - & $\downarrow$ & - & - & - & - \\
\hline Svájc & 32 & $\uparrow \uparrow \uparrow$ & $\uparrow$ & $\uparrow$ & - & - & - & - & - & - & - \\
\hline Svédország & 26 & $\downarrow$ & - & $\downarrow$ & - & - & - & - & - & - & - \\
\hline Szerbia & 13 & $\downarrow \downarrow \downarrow$ & $\downarrow \downarrow$ & - & - & $\downarrow$ & - & - & - & - & - \\
\hline Szlovénia & 21 & $\uparrow(7)$ & - & - & - & $\uparrow$ & - & - & - & - & - \\
\hline Törökország & 24 & $\uparrow \uparrow$ & - & - & - & - & $\uparrow$ & - & - & - & $\uparrow$ \\
\hline Ukrajna & 9 & $\uparrow$ & - & - & - & - & $\uparrow$ & - & - & - & - \\
\hline Wales & 38 & - & - & - & - & - & - & - & - & - & - \\
\hline
\end{tabular}

Lengyelország 1 és Svájc, illetve ugyanennyit ront Dánia, Izland és Szerbia. A hivatalos holtverseny eldöntésére szolgáló szabályok közül az ellenfelek táblapontszámával megegyező TB4 utal erre.

Az ezt követő iterációs lépésekben gyakran az első irányával megegyező, de annál kisebb mértékü változás történik: a fentiek közül például Fehéroroszország és Szlovénia $k=5$-nél még egy helyezést javít, Dánia $k=3$-nál és $k=9$-nél egyet-egyet ront. Hollandia esetén nem történik újabb változás, Románia viszont jelentős részben visszanyeri elvesztett pozícióit, a közvetett ellenfelek ereje szinte teljesen kompenzálja a közvetlenek gyengeségét. 
A változások abszolútértékének monotonitása alól az egyetlen kivétel Litvánia, amely $k=1$-nél kettő, $k=2$-nél viszont négy (!) pozíciót ront, tehát elsősorban nem az ellenfelek, hanem azok ellenfeleinek gyengesége dönt. Egy másik érdekes esetet jelent a viszonylag egyenletes megoszlással öt helyezést javító Ausztria. A változások iránya tekintetében már több csapatnál sem teljesül annak egyirányúsága: ilyen a már említett Románián kívül Horvátország, Izland, Lengyelország 1 és Olaszország. Eszerint az első körben pozíciót változtató csapatok egy részénél a későbbi iterációs lépésekben ez (bizonyos mértékben) korrigálódhat.

Az első helyen $k=2$-nél Franciaország váltja Azerbajdzsánt, a hat vezető pozícióban a hivatalos rangsorhoz képest - az azonos mérkőzéspontszámmal rendelkező Oroszország és Örményország helycseréjét leszámítva - ez az egyetlen változás. Utóbbi egyértelműen indokolt, Oroszország a verseny elején mutatott gyengébb teljesítmény után, külső körön jutott fel a dobogóra. Franciaország és Azerbajdzsán viszonyán lehet vitatkozni, az előbbi sorsolása talán kicsit nehezebb volt (ezt tükrözheti magasabb TB4 mutatója), a másik csapat viszont nem szenvedett vereséget. Mindenesetre sokat segítene, ha eggyel több forduló kerül megrendezésre, így lejátszhatták volna az Azerbajdzsán-Oroszország mérkőzést. Az utolsó változás Törökország és Montenegró helycseréje $k=12$-nél. A legkisebb négyzetek módszere nem csupán az azonos mérkőzéspontú csapatok közötti holtversenyek eldöntésére szolgál, több esetben előfordul, hogy kettővel kevesebb pontszámú résztvevő előz meg egy, a hivatalos sorrend szerint nála jobb csapatot (amint azt Szlovénia és Hollandia példája mutatta).

A svájci rendszerü versenyek hivatalos rangsorolásának hibáira a 2011-es verseny szolgáltat kiváló példát. Az első hat mérkőzésén három győzelmet és három döntetlent elérő, akkor hatodik Franciaország az utolsó három fordulóban vereséget szenvedett, így a vele azonos mérkőzéspontszámú csapatokhoz képest jóval nehezebb ellenfelekkel találkozott. Az $L S\left(A^{M P}\right)$ rangsor iteratív felbontása a 7.2. táblázatban használt jelölésekkel:

\begin{tabular}{lccccccccc} 
Hatvány & $\mathbf{0}$ & $\mathbf{1}$ & $\mathbf{2}$ & $\mathbf{3}$ & $\mathbf{4}$ & $\mathbf{5}$ & $\mathbf{6}$ & $\mathbf{7}$ & $\mathbf{8}$ \\
\hline Franciaország & 19 & $\uparrow(4)$ & $\uparrow \uparrow \uparrow$ & - & - & $\uparrow$ & - & $\uparrow$ & -
\end{tabular}

Tehát a csapat a hivatalos 19. helyett a mérkőzéspontokon alapuló eredménymátrixot használó legkisebb négyzetek módszerével már a hetedik iterációs lépés után 10. helyezést ért el. A javulás főként ellenfelei, illetve ellenfelei ellenfelei erejének köszönhető. A furcsa jelenségre szakértők is felfigyeltek. ${ }^{33}$

33 A franciák sokáig az élbolyban küzdöttek, a végén a svájci rendszer minden „átkának” az áldozataivá váltak. Lásd http://sakkblog.postr.hu/sokan-palyaznak-dobogos-helyezesre-izgalmas-utolso-fordulo-dont. Mi azonban úgy véljük, a párosítás különbözőségből fakadó torzítások jelentős részben kiküszöbölhetők lennének a javasolt módszerek alkalmazásával, így egyáltalán nem, vagy sokkal ritkábban kellene a svájci rendszer hibáiról beszélni. 


\subsubsection{A rangsorok összehasonlítása és értékelése}

A különböző rangsorok összehasonlítása után rátérhetünk a legjobb sorrend kiválasztásának kérdésére. Ehhez három megközelítést választottunk:

- Előrejelző képesség vizsgálata (predictive performance);

- Múltbeli eredmények leírása, mintailleszkedés (retrodictive performance);

- A rangsor változásai az egyes fordulók után.

Pasteur (2010) az első kettőt említi a matematikai alapú rangsoroló módszerek kritériumaként: az előrejelző eljárások célja a jövő minél pontosabb megbecslése, a múltbeli eseményeket közelítőknél ezzel szemben a mintára való illeszkedés számít. Az ökonometriai modellek többségét szintén e két csoportba sorolhatjuk.

A harmadik szempontot, a rangsor minél kisebb változékonyságát két okból is fontosnak tartjuk. Egyrészt sem a közönség, sem a résztvevők nem szeretik, ha túlságosan instabil az eredmény, egy vereség vagy győzelem után nagymértékben módosul a csapat helyezése. Természetesen a másik véglet szintén kerülendő, de ez nehezen számszerűsíthető. Másrészt axiomatikus megközelítésben is nehéz meghatározni a svájci rendszerű versenyek optimális fordulószámát, az átváltást az esemény időbeli korlátai és a játékosok terhelése, illetve a stabil sorrend kialakítása között. Ezért egyértelmüen jobbnak tünik egy olyan módszer, ami robusztusabb, kevésbé reagál a váratlan eredményekre, hiszen ekkor a gyengébben szereplő résztvevők nem érvelhetnek azzal, hogy csak egy-két további forduló kellett volna képességeik érvényesítéséhez. Ennek alapján némi megszorítással úgy véljük, kedvezőbbnek tekinthető, ha a vizsgált eljárással kapott rangsorok kevésbé változnak az egyes fordulók között.

A múltbeli és jövőbeli eredmények leírásának képességét két mutatóval mérjük: egy alacsonyabbra értékelt csapat hány mérkőzés-, illetve táblapontot szerzett egy nála jobb ellenében. Ezek egyike sem veszi figyelembe a helyezések eltérésének nagyságát, nincs különbség aközött, hogy az utolsó résztvevő az első vagy az utolsó előtti ellen szerez pontot. A két mérőszám összehasonlításra így is alkalmas, emellett nem merül fel az önkényesség vádja, ami bármilyen más definíciónál nehezen lenne elkerülhetö. Jövőbeli kutatásainkban azonban megfontolandónak tartjuk ezen megkötés enyhítését, módosítását.

A számított mutatókat összesen öt diagramon szemléltetjük. Mindkét versenyre minőségileg azonos eredményeket kaptunk, és az alkalmazott módszerek is hasonlóan viselkednek, ezért eltekintünk az összes részlet közlésétől.

A 7.4. ábrán a hátrébb végző ellenfelek által az egyes fordulókat követően szerzett mérkőzés-, illetve táblapontok kumulált száma szerepel. A számítás a harmadik körtől indul, amikor az összehasonlítási multigráf összefüggővé válik. Az általunk számított sorrendek fokozatosan jobbnak bizonyulnak a hivatalosnál, különösen 
7.4. ábra. Teljes előrejelző képesség, 2011-es sakkcsapat EB

(a) Mérkőzéspont, $A^{M B}$ eredménymátrix

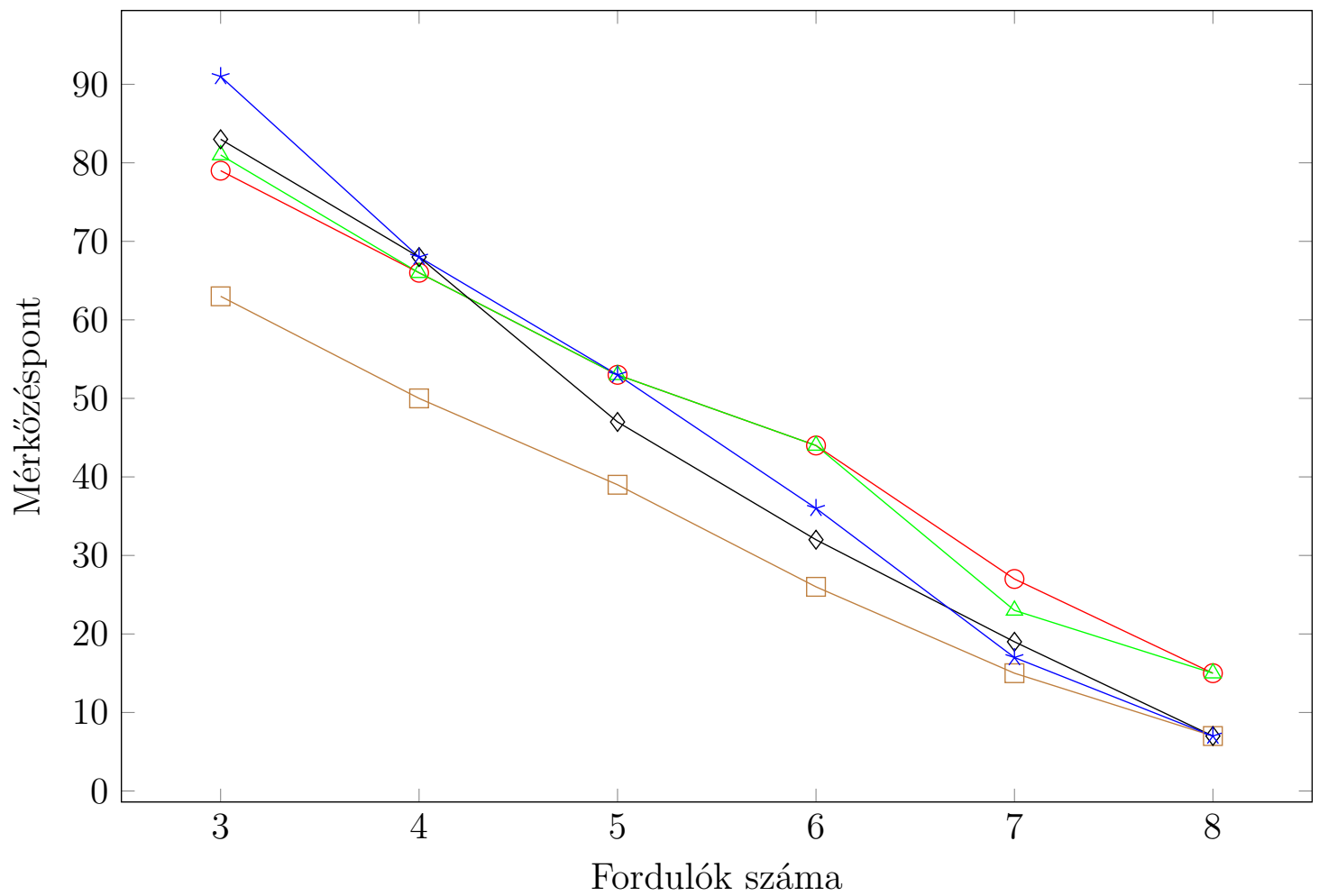

$\square$ Start $\frown$ Off $\triangle \mathrm{G} 2 \multimap \mathrm{S} 2 \nrightarrow \mathrm{L} 2$

(b) Táblapont, $A^{M B}$ eredménymátrix

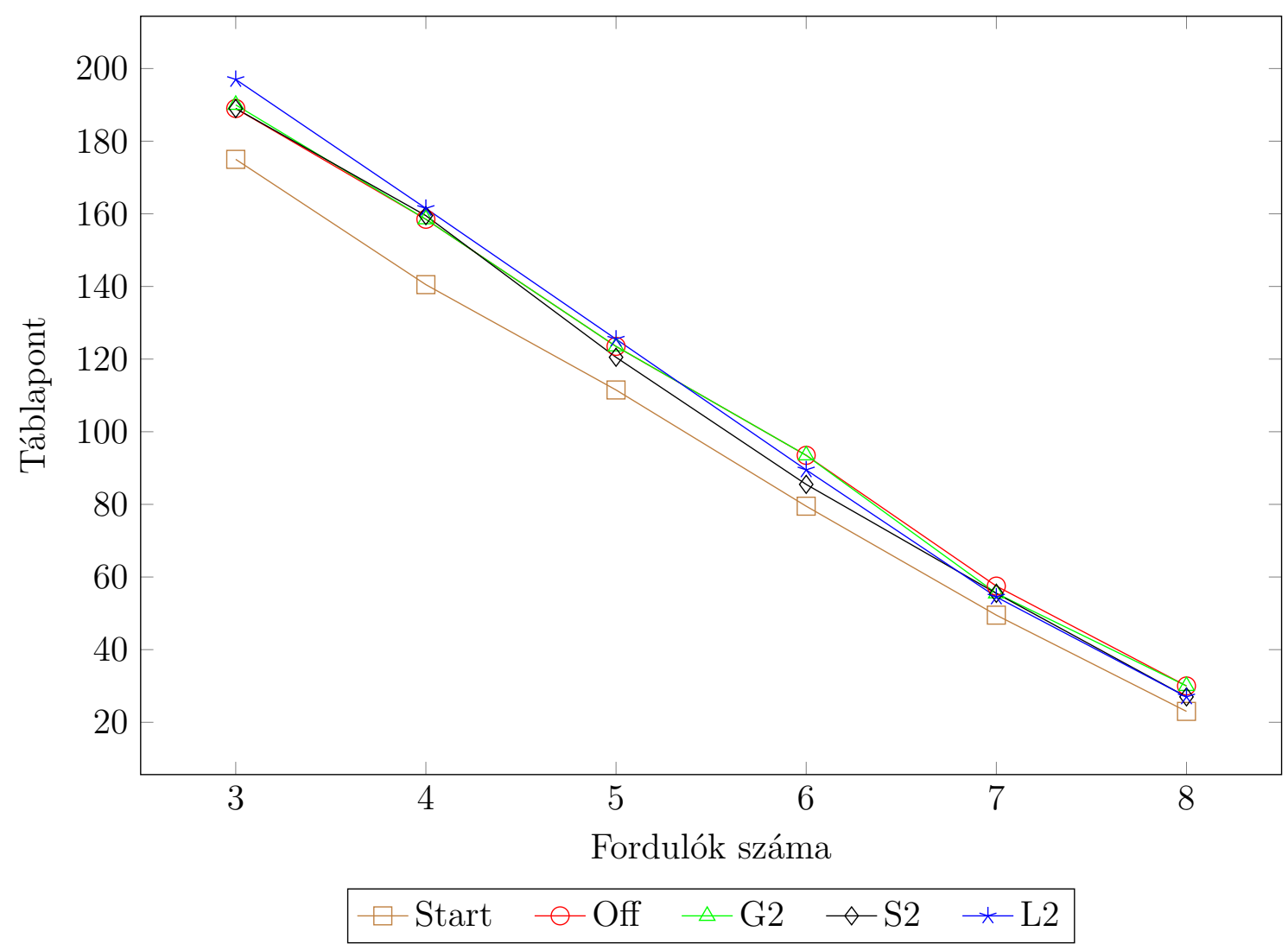


a mérkőzéspontok tekintetében, a Start rangsort azonban a verseny végére sem képesek megverni, annak ellenére, hogy az egyáltalán nem veszi figyelembe a korábbi eredményeket. Vagyis a mérkőzések kimenetelét valamivel jobban befolyásolja a csapatok képessége, mint a verseny előző szakaszában megfigyelt eredményeik, ami azonban nem zárja ki egyes résztvevők látványosan rosszabb vagy jobb teljesítményét. A 2013-as versenyen kevésbé figyelhető meg a hivatalos sorrendhez képesti fölény, és a verseny végére a Start sem lesz jobb előrejelző a javasoltaknál.

A némileg váratlan következtetés talán csak abból adódik, hogy túl hosszú időszakra akartunk előrejelezni, ezért jobb mutató lehet kizárólag a következő kör vizsgálata. Ez az F.IV. Függelék F.5. ábráján látható, ismét a mérkőzés-, illetve táblapontok alapján. Nagyjából minden rangsor azonosan teljesít, ezúttal a Start sem különbözik a többitől. Tehát az elörejelzés alapján nem tudunk optimális sorrendet választani.

Egy másik megközelítést jelent a múltbeli eredmények leírására való képesség. A 7.5. ábrán az egyes fordulókban a gyengébb ellenfelek által szerzett mérkőzés-, illetve táblapontok kumulált száma szerepel a Start, a hivatalos, és három általunk számított rangsor esetén. Ez megint a harmadik körtől kezdve számítható, de ezúttal a verseny végén is értelmezhető (ahol az előrejelzés értelemszerüen nem vizsgálható).

Ugyan nem feltétlenül meggyőző mértékben, de egyértelműen az LS eljárás tűnik jobbnak, a minimális értékek többsége ezen módszer valamelyik változatánál található. Az eredménymátrix választása nem tünik befolyásoló tényezőnek, ahogy azt az MDS skálatérképek (7.2. és 7.3. ábra) mutatták, esetleg a mérkőzéspontnak nagyobb szerepet juttató $A^{M P}$ és $A^{M B}$ minősíthetők kedvezőbbnek. Az általánosított sorösszeg mintailleszkedése a legkisebb négyzetek és a hivatalos rangsor között helyezkedik el. Hasonló következtetésekre jutunk a 2011-es Európa-bajnokság vizsgálatakor.

Harmadik kritériumként a rangsorok stabilitásának vizsgálatát említettük. Ez a Start rangsorra nyilván nem értelmezhető, az összes többire azonban igen, a harmadik és negyedik körök közötti változástól kezdve. Következtetéseinket az egymás utáni fordulók rangsorainak összehasonlításából vonjuk le, ezúttal is a Kemény- és súlyozott távolságok használatával.

A 7.6. ábra a 2011-es sakkcsapat Európa-bajnokság rangsorainak robusztusságát szemlélteti. Noha azok változékonysága nem szigorúan monoton csökken (ezt az egyes körök eredményei is befolyásolják), megfigyelhető a hanyatló tendencia, miután az aktuális forduló jelentősége egyre kisebb a már ismert mérkőzésekhez viszonyítva. A Kemény-távolság esetén a kezdeti időszakot leszámítva, a súlyozott távolságnál pedig végig a legkisebb négyzetek módszerével kapott $L S\left(A^{M P}\right)$ sorrend bizonyult a legstabilabbnak. A második helyezett a $G R S_{2}\left(A^{M P}\right)$, ezt követi a $G R S_{1}\left(A^{M P}\right)$, majd a hivatalos. Tehát az ellenfelek teljesítményének figyelembevétele csökkenti a sorrend változékonyságát, a beérkező új információ hatását. A mintázat hasonló, de 
7.5. ábra. Mintailleszkedés, 2013-as sakkcsapat EB

(a) Mérkőzéspont, $A^{M P}$ mérkőzéspont alapú eredménymátrix

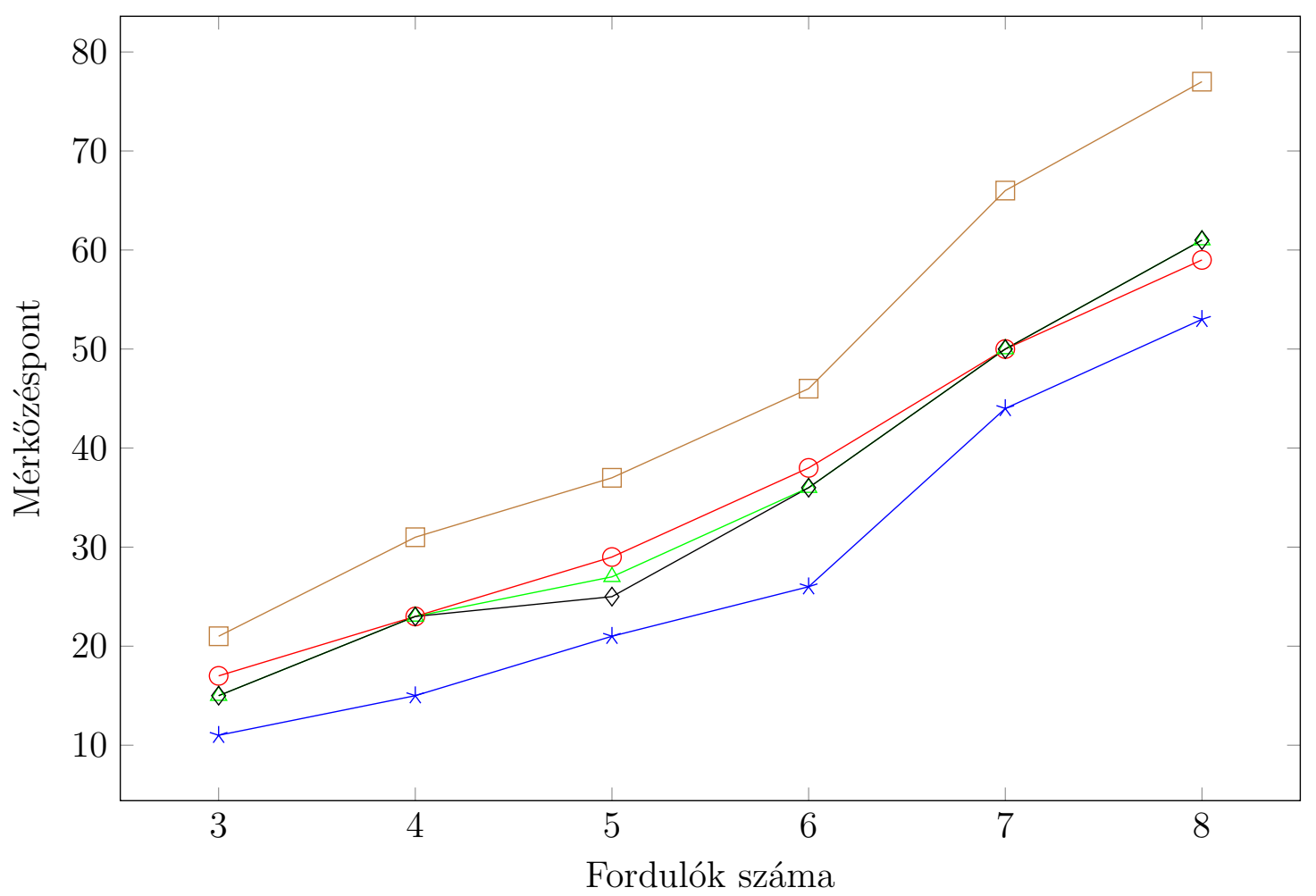

Start $\bullet$ Off $\triangle \mathrm{G} 2 \triangleleft \mathrm{S} 2 \quad$ * L2

(b) Táblapont, $A^{M P}$ mérkőzéspont alapú eredménymátrix

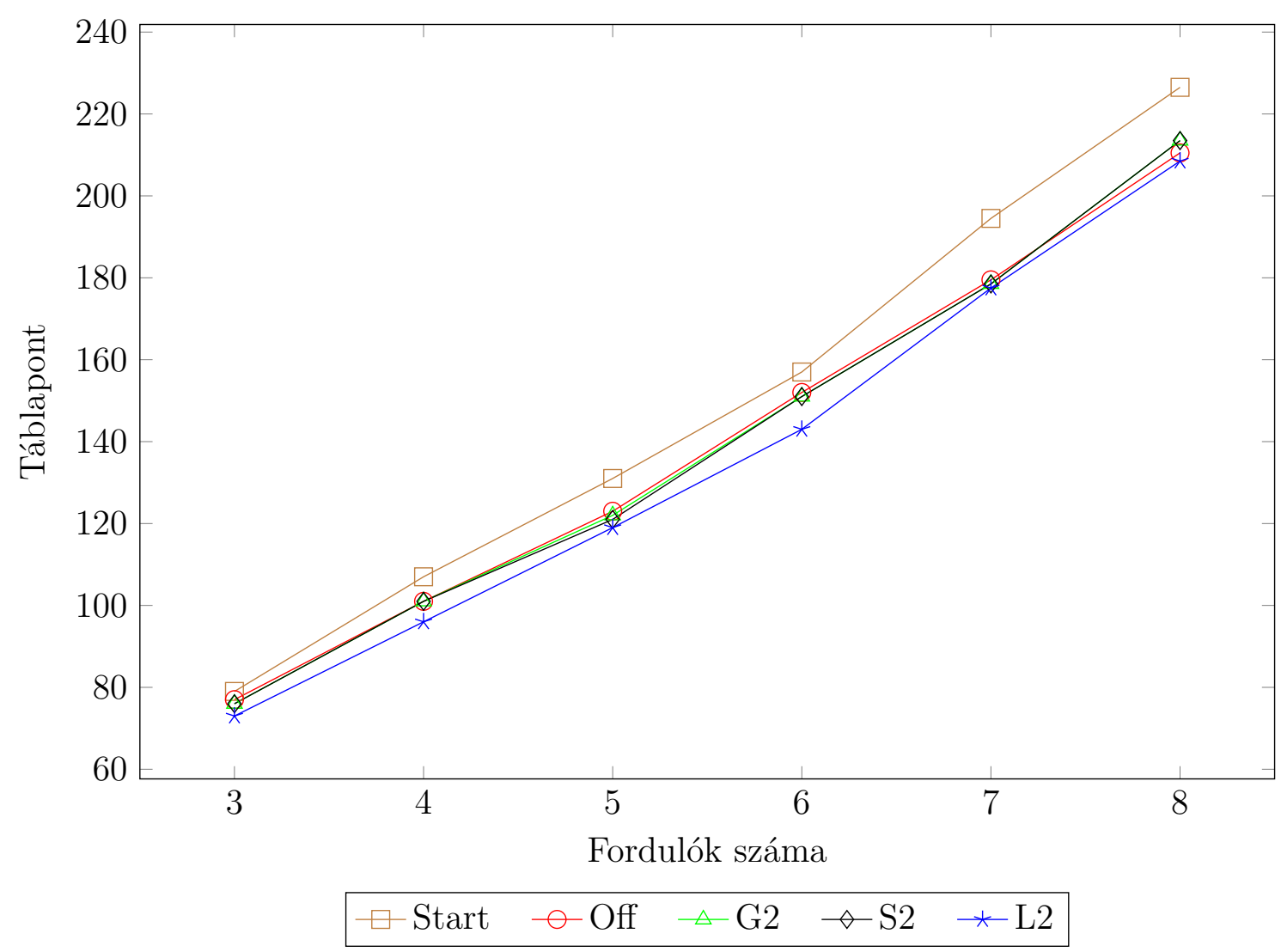


7.6. ábra. Stabilitás a fordulók között, 2011-es sakkcsapat EB

(a) Kemény-távolság, $A^{M P}$ mérkőzéspont alapú eredménymátrix

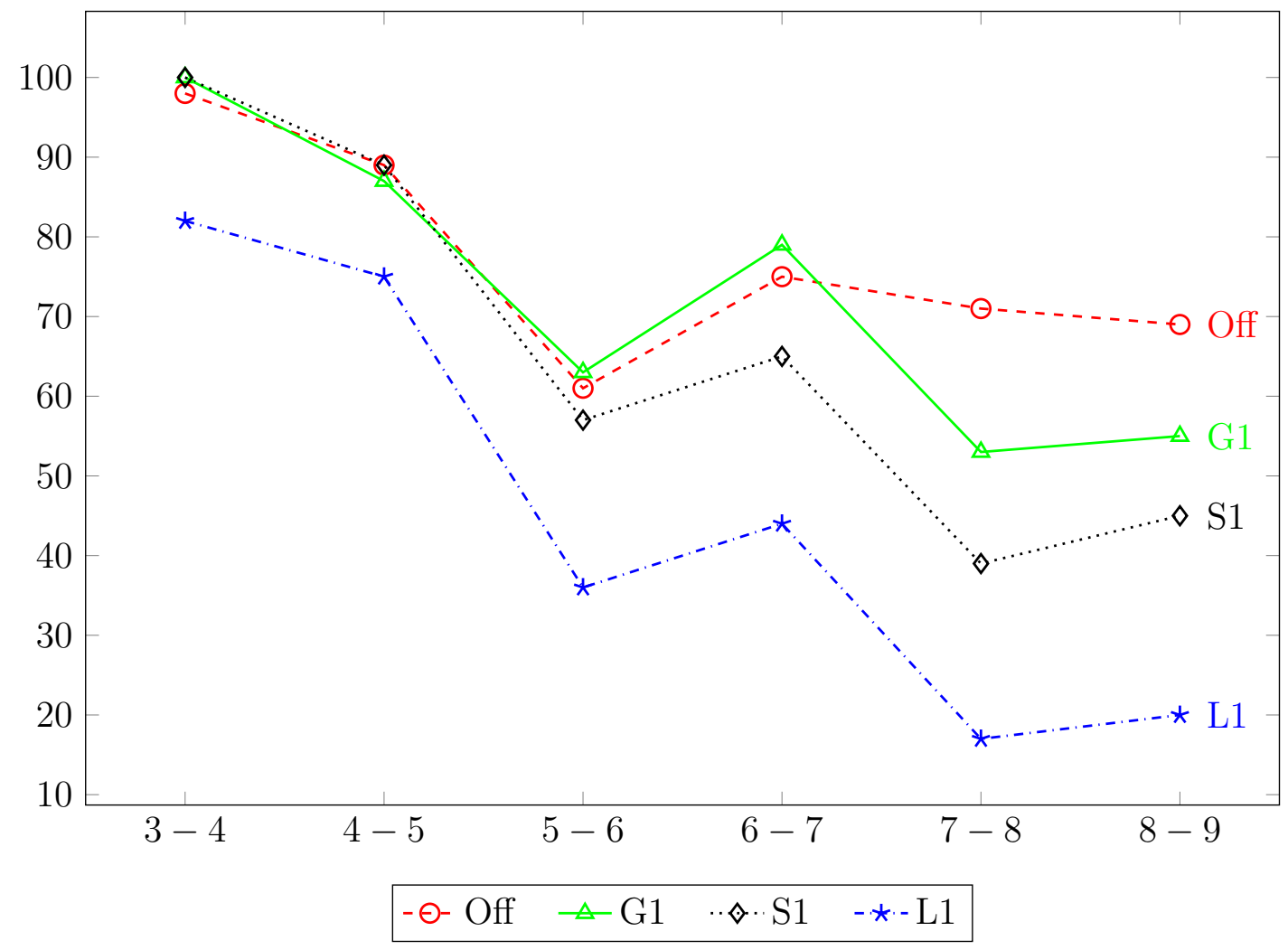

(b) Súlyozott távolság, $A^{M P}$ mérkőzéspont alapú eredménymátrix

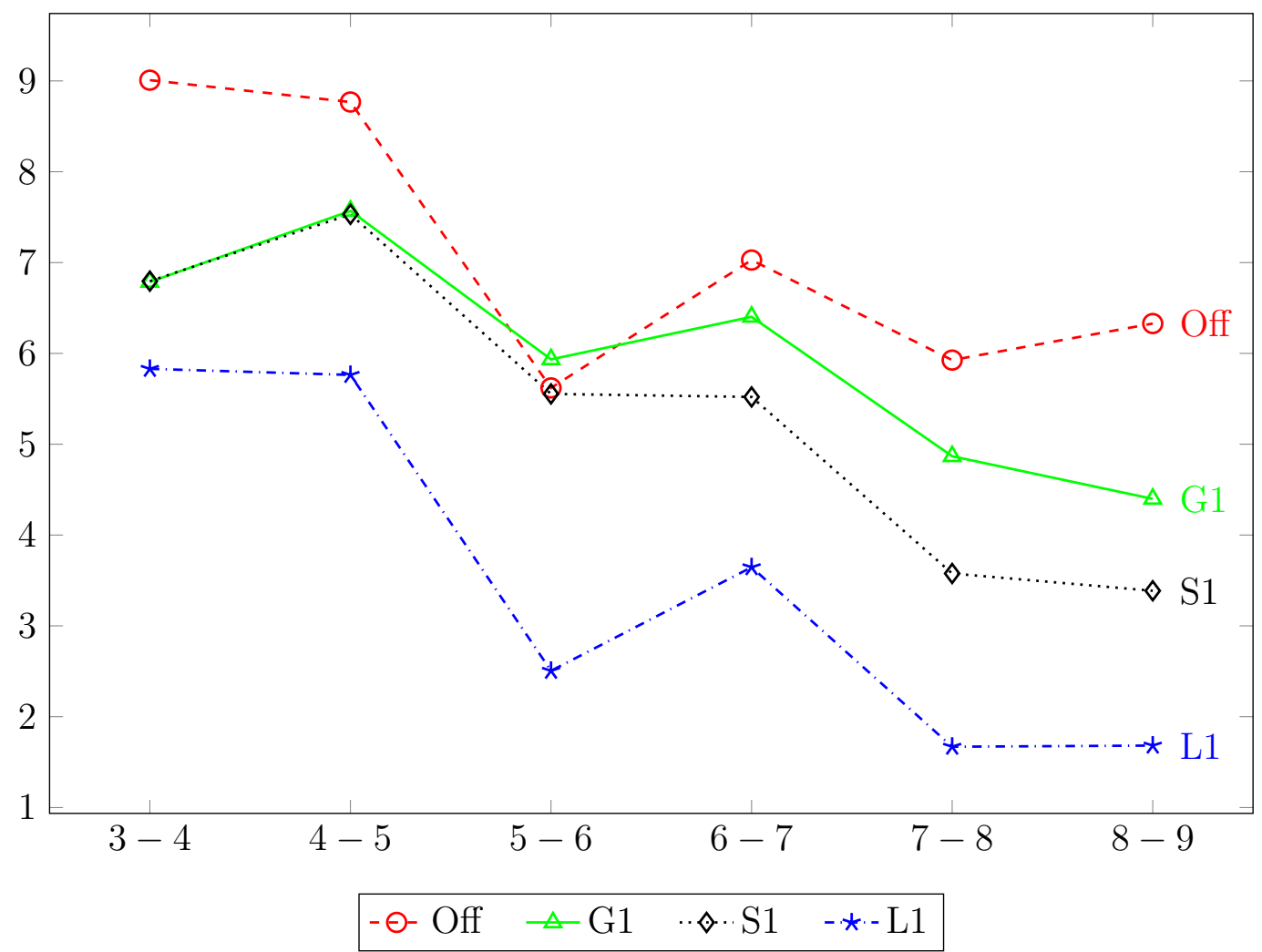


a különbség sokkal nagyobb a súlyozott távolság esetén, a javasolt rangsorok éppen a kritikus tartományban, az első néhány pozícióban bizonyultak robusztusabbnak.

Az ábrán nem szereplő, az $A^{M B}, A^{B M}$ és $A^{B P}$ eredménymátrixból számított rangsorok szintén a hivatalosnál kevésbé változékonyak, jellemzően azonban némileg rosszabbak a bemutatottnál. Ezekre is érvényes az $L S<G R S_{2}<G R S_{1}$ összefüggés, az $\varepsilon$ paraméter csökkenésével emelkedő instabilitás. Az eltérés ugyancsak a súlyozott távolságnál nagyobb, a változékonyság kisebb a mezőny első felében.

A 2013-as versenyre számolt hasonló mutatók az F.IV. Függelék F.6. ábráján láthatók. Ezúttal kevésbé jelentős a stabilitásbeli különbség, ami azonban kizárólag eredményeink megbízhatóságát befolyásolhatja. Ismét érvényes az $L S<G R S_{2}<$ $<G R S_{1}$ reláció, bár az utóbbi kettő lényegében a hivatalossal azonosan teljesít. Szintén csak mérsékelten igaz, hogy súlyozott távolságnál nagyobb eltérések figyelhetők meg. A másik három eredménymátrixszal kapott rangsorok közül az $L S$ eljárás a legrobusztusabb, a $G R S_{2}$ módszer helyenként, a $G R S_{1}$ pedig szinte mindig a hivatalosnál rosszabbul teljesít. Összességében kijelenthető, hogy a Buchholz pontszámot általánosító legkisebb négyzetek módszere különösen stabil, használata fóként akkor ajánlott, ha szeretnénk elkerülni a lejátszott körök számából fakadó torzításokat.

Ahogy korábban említettük, a rangsorok nagyobb stabilitása ugyan nem feltétlenül elönyös a nézettség szempontjából, mert csökkenti a meglepetések valószínüségét, viszont sokkal megalapozottabbá teszi a svájci rendszerű verseny előre adott számú körének lejátszása után kialakuló sorrendet. Véleményünk szerint ez utóbbi hatás a döntő, a változékonyság nem hanyatlik olyan kritikus szintre, ami már értelmetlenné tenné az új fordulók rendezését.

\section{3. Összegzés}

A fejezetben a páros összehasonlításokon alapuló pontozási eljárások egy alkalmazását mutattuk be a svájci rendszerü sakk csapatversenyek rangsorolására. Elsőként a feladat általános jellemzőivel, a nem körmérkőzéses esetben felmerülő kérdésekkel foglalkoztunk (7.1.1. szakasz). Áttekintettük a hivatalos lexikografikus rendezéseket, az egyéni és a csapatversenyek rendezésének részleteit, rávilágítottunk a külső és belső kör jelentőségére a svájci rendszerű tornákon. A 7.1.2. részben megállapítottuk, hogy a mérkőzésmátrix definíciója szinte triviális, az eredménymátrix kiválasztása pedig az SCC tulajdonság segítségével megfelelő alapokra helyezhető. Részletesen taglaltuk az előző fejezetekben bevezetett axiómák jelentését a konkrét esetben.

A 7.2. alfejezetben két sakkcsapat Európa-bajnokság eredményeit elemezzük. A 7.2.1. rész ismerteti a kiválasztott példákat és a használt módszereket. A kapott rangsorok összehasonlítását Can (2014) javaslatából kiindulva, a Kemény- és a súlyozott távolságok vizsgálatával végeztük (7.2.2. szakasz). A sokdimenziós skálázás 
lehetővé teszi a kapott sorrendek grafikus szemléltetését. A legkisebb négyzetek módszere bizonyult a legjobb választásnak, mert ez függ legkevésbé az eredménymátrix megválasztásától. Mivel az ebből adódó sorrendek a hivatalos rangsortól viszonylag messze helyezkedtek el, a 7.2.3. szakaszban a 4 . fejezetben bemutatott dekompozícióval (Csató, 2014a) tártuk fel az eltérés okait, alátámasztva az ellenfelek teljesítményének figyelembevételére vonatkozó javaslatunkat.

A rangsorok értékélését a 7.2.4. részben három különböző megközelítésben, az előrejelző képesség, a mintailleszkedés és a robusztusság alapján vizsgáltuk. Az elsőben nem mutatkozott jelentős eltérés közöttük, a második, de főleg a harmadik szempont viszont további érveket szolgáltat a legkisebb négyzeteke módszerének alkalmazása mellett. Következtetéseink megerösítették előzetes várakozásainkat.

A 7. fejezet egésze saját eredménynek tekinthető. Bár korábban is születtek javaslatok rekurzív alapú módszerek használatára svájci rendszerű sakkversenyeken (Brozos-Vázquez et al., 2010), ez tekinthető az első axiomatikus megközelítésü gyakorlati vizsgálatnak. A rangsorolási problémaként való modellezés kérdését - legalábbis a sakk csapatversenyek esetén - sikerült lezárnunk, és jelentős lépéseket tettünk a megfelelő pontozási eljárás kiválasztása felé. Az alkalmazást bemutató rész szintén tartalmaz innovatív elemeket. Ilyennek tekintjük a súlyozott távolság számítását, mely nagy valószínüséggel Can (2014) karakterizációjának első gyakorlati megvalósítása, valamint a legkisebb négyzetek módszere iteratív felbontásának (Csató, 2014a) alkalmazását. Tudomásunk szerint egy korábbi cikkünktől (Csató, 2013a) eltekintve a sokdimenziós skálázást sem használták rangsorok összehasonlítására. Ezenkívül a stabilitás bevezetését emelnénk ki a svájci rendszerű versenyek rangsorolásának értékelési szempontjaként.

Az előzőek szerint a svájci rendszerű sakk csapatversenyek hivatalos rangsorai erősen vitathatók, helyettük több okból ajánlható az általánosított sorösszeghez és a legkisebb négyzetek módszeréhez hasonló rekurzív eljárások használata. BrozosVázquez et al. (2010) ezek legfóbb erényeként említi a tornán keletkező összes információ beépítését, a holtversenyek előfordulásának alacsony valószínűségét, és a nem lejátszott mérkőzésekből fakadó nehézségek kezelését. Bár az utóbbi jelenség az általunk vizsgált példákban nem fordult elő, az első két előnyt mi is megerősíthetjük. Emellett két további érvet szolgáltatunk: a rangsor sokkal kevésbé függ a mérkőzésvagy táblapontszám választásától, és jóval robusztusabb a beérkező új eredményekre nézve, tehát a verseny végén kapott sorrend sokkal megbízhatóbbak.

A Brozos-Vázquez et al. (2010) által felsorolt hátrányok véleményünk szerint nem jelentősek. A pontozási eljárások a résztvevők számára talán tényleg nehezen érthetők, de ez a svájci rendszerben rendezett tornák minden részletére igaz. A számítás a dekompozíció révén a $P$ mátrix első néhány hatványának felírásával is elvégezhető. Bár csak az első 3-4 kör után kapható rangsor, ezt megelőzően nyugodtan használható 
az eredeti pontszám módszer. Ezek alapján úgy véljük, érdemes lenne megkísérelni a (Buchholz pontszám általánosítását jelentő) legkisebb négyzetek módszerének alkalmazását. Első lépésként megfontolandó lehet csak a holtverseny eldöntésére szolgáló szabályként történő bevezetése is.

Elemzésünk számos kérdést vet fel. További csapatversenyek vizsgálata, szimulációja megerősítheti vagy cáfolhatja fóbb következtetéseinket. Utólagos elemzés tárgyává tehető néhány múltbeli anomália, például az 1980-as máltai (helyesebben a máltai fóvárosban, La Vallettában megrendezett férfi) sakkolimpia hazánkban elhíresült esete (Kőrösi és Schepp, 2014). ${ }^{34}$ Megfontolásra érdemes a jó előrejelző képességű Start rangsor felhasználása a holtversenyek eldöntésére, így „díjazva” az erejükön felül teljesítő csapatokat (Kőrösi és Schepp, 2014).

A vizsgálat során eltekintettünk több, a gyakorlatban előforduló komplikációtól, mint a világos-sötét probléma, vagy a lejátszott mérkőzések számának különbözősége (például a résztvevők páratlan száma miatt). Szintén csak részben tárgyaltuk az általánosított sorösszeg $\varepsilon$ paramétere megválasztásának problémáját.

Végül az általunk ajánlott rangsorolás két lehetséges felhasználását említenénk. Egyrészt a kapott sorrendek beépíthetők a párosító algoritmusba, ami hozzájárulhat a sorsolás kiegyensúlyozásához. Másrészt a rangsor fordulók közötti stabilitásának elemzése segíthet a lejátszandó körök számának meghatározásában, melynek értéke a résztvevők száma és a szervezés korlátainak ismeretében endogénné tehető. ${ }^{35}$

Néhány további észrevétel, ajánlás a disszertáció záró fejezetében olvasható. A fóbb eredmények publikálása elkezdődött (Csató, 2014c).

${ }^{34}$ Az egyaránt veretlen magyar és szovjet csapat holtversenyét eldöntő Buchholz-számítás az utóbbi csapatnak kedvezett, miután az utolsó, tizennegyedik fordulóban az első helyek szempontjából érdektelen görög-skót mérkőzésen váratlan fölénnyel nyertek a görögök - többek között a legjobb skót versenyző hazautazásának köszönhetően.

35 Számunkra úgy tünik, ennek meghatározása jelenleg ad hoc döntéseken múlik: a 2006-os torinói bajnokságon 148 (férfi), illetve 103 (női) csapat 13, a 2008-as drezdain pedig 146, illetve 111 résztvevő 11 mérkőzést játszott. Ráadásul a lexikografikus rendezés fő szempontja az első esetben a táblapontok, a másodikban a mérkőzéspontok száma volt. 


\section{8. fejezet}

\section{A páros összehasonlítások további alkalmazásai}

It is not the actual programming that is interesting. But it is what you can accomplish with the end results that are important.

Dennis MacAlistair Ritchie

Ebben a fejezetben a páros összehasonlításokon alapuló pontozási eljárások felhasználásának területeit tekintjük át, röviden bemutatunk néhány alkalmazást, és tanácsokat fogalmazunk meg a gyakorlati felhasználók számára.

\section{1. Ígéretes felhasználási területek}

Országok gazdasági teljesítményének összehasonlításakor elengedhetetlen az eltérő árszínvonalból adódó különbségek kiszürése. Bár az egyes fogyasztási javak és szolgáltatások árai elvben jól mérhetők, az aggregáció során nem egyértelmü, milyen termékszerkezettel kell azokat összesúlyozni. Tekintsük a vizsgált országok $N=$ $=\{1,2, \ldots, n\}$ és a termékek $M=\{1,2, \ldots, m\}$ halmazát, legyen az $i \in N$ országban a $k \in M$ fogyasztási jószág ára $p_{k}^{i}$, mennyisége pedig $q_{k}^{i}$. A leggyakrabban használt Fisher-index (Fisher, 1922) az $i$ és $j$ országok árszínvonalának összehasonlítására (a $p$ felső index arra utal, hogy az árakat vetjük össze egymással):

$$
F_{i / j}^{p}=\left(\prod_{\ell \in N} \frac{\sum_{k \in M} q_{k}^{\ell} p_{k}^{i}}{\sum_{k \in M} q_{k}^{\ell} p_{k}^{j}}\right)^{1 / n}
$$

Ez a mutató rendelkezik a reciprocitási tulajdonsággal $\left(F_{j / i}^{p}=1 / F_{i / j}^{p}\right)$, ugyanakkor semmi sem garantálja tranzitivitását $\left(F_{i / k}^{p}=F_{i / j}^{p} \cdot F_{j / k}^{p}\right)$, a multiplikatív módon felírt páros összehasonlítás mátrix inkonzisztens lehet. Ennek kezelésére többnyire a legkisebb négyzetek eljárást használják, ami a vásárlóerő-paritás számításában - 
kidolgozói nevéből - EKS-módszerként ismert (Éltető és Köves, 1964; Szulc, 1964). A kiindulási alapokon érdemben az azóta eltelt 50 évben sem módosítottak. Itt az egyenlő súlyozás módosítása jelenthet új kutatási irányt, miután a magas szinten aggregált adatok megbízhatóságáról számos kiegészítő információ áll rendelkezésre. Például a $\sum_{k \in M} q_{k}^{\ell} p_{k}^{i} / \sum_{k \in M} q_{k}^{\ell} p_{k}^{j}$ hányadosok eltérése mutathatja az egyes országok termékszerkezetének hasonlóságát (Rao és Timmer, 2003).

A tudományos teljesítmények számszerüsítése iránt felmerülő igények kielégítése gyakran folyóiratok / tudományos kutatók / szakmai mühelyek egymásra való hivatkozásai alapján történik. Az ismert referenciák megadják egy kiválasztott objektumpár összehasonlításának eredményét, melyek révén képet kapunk azok jelentőségéről. Ehhez még az sem szükséges, hogy a kiválasztott folyóiratok azonos tudományterületekről származzanak, elegendő lehet, ha bármely kettő között találunk olyan láncot, ami alapján feltárható azok relatív fontossága. A tudománymetriában azonban megjelenik egy új tényező, a vizsgált időszak alatt megjelent cikkek száma: hosszabb folyóiratokra nyilván nagyobb valószínüséggel érkeznek külső hivatkozások.

A jól ismert impakt faktor (Garfield, 1955) egyáltalán nem tesz különbséget az idézések között, amit többen komoly hibának tekintenek (Rétallér és Tasnádi, 2013). Pinski és Narin (1976) az invariáns módszer egy, a megjelent cikkek számával korrigált változatát vezette be a folyóiratok rangsorolására, az általuk adott eljárást Palacios-Huerta és Volij (2004) karakterizálta. Kóczy és Nichifor (2013) megmutatta, hogy mindkettő érzékeny a cikkek részekre bontására, ezért egy ezt kiszűrő módosítást javasolt, ami a fair bets módszerhez vezet. Kóczy és Strobel (2010) egy másik eljárást, a tournament módszert ajánlja az invariáns módszer hibáinak kiküszöbölésére. Ez nem veszi figyelembe a megjelent cikkek számát, ezért - számos más, a 2.4. alfejezetben említett eljárás mellett - egyszerüen beilleszthető modellünkbe. Hasonló kérdések merülnek fel weblapok rangsorolásánál, ilyen elven alapul a Google keresőmotorjának müködése is (Brin és Page, 1998).

A feladat nem ismeretlen a pszichológiában sem, az elsők között bukkant fel a Thurstone (1927) cikkben. A későbbiekben több pszichológus játszott úttörő szerepet a rangsorolási módszerek kidolgozásában (Mosteller, 1951; Gulliksen, 1956; Kaiser és Serlin, 1978). E területen azért lehet hasznos a páros összehasonlítások bevezetése, mert a kísérleti alanyok gyakran nem képesek abszolút skálán értékelni az egyes tényezőket, csak azok relatív viszonyának megbízható leírása várható tőlük.

Ugyanez a probléma jelentkezhet egy konferenciára beérkezett absztraktok elfogadásakor: mivel egy-egy értékelésre felkért szakember csak a neki kiosztott dolgozatokat látja, nem tudja megítélni a teljes mezőny erejét. Ennek következtében az általa adott pontszám erősen szubjektív lehet, vannak szigorú és engedékeny bírálók, az ebből eredő torzítások kiszűrésében pedig segítséget nyújthat a páros összehasonlítási módszertan (Bozóki et al., 2014). A megközelítést borszakértők értékelésére is 
alkalmazták (London és Csendes, 2013).

Hasonló megfontolások indokolják pontozási eljárások alkalmazását a napjainkban egyre népszerübb internetes termékértékelő és -összehasonlító oldalak esetében. Jiang et al. (2011) a Netflix prize (http://www.netflixprize.com) adatbázist használta filmek rangsorolására - a páros összehasonlítások kimenetelét egy-egy kiválasztott néző értékelései alapján meghatározva -, az általuk adott eljárás alkalmas a beérkező vélemények különböző skálázásának kiküszöbölésére.

Sok, több százas vagy ezres nagyságrendű, egymástól többé-kevésbé független egyéni döntés alapján nagy biztonsággal állíthatók fel különböző sorrendek. A módszertant felsőoktatási intézmények felvételizői preferenciák alapján történő rangsorolására használta Avery et al. (2013), egy nemrég megjelent hazai cikkben is ezzel a megközelítéssel találkozunk (Telcs et al., 2013a; Csató, 2013d; Telcs et al., 2013b). Machado et al. (2012) pedig kórházak értékelését javasolta az orvosrezidensek választásainak felhasználásával.

Szavazási modellekben ezzel analóg feladatot jelent a preferenciák aggregálása. Ekkor a két, egymással versengő alternatívára leadott szavazatok megoszlása képviselheti a páros összehasonlítás eredményét (Chebotarev és Shamis, 1998a).

Végül az egyik klasszikus alkalmazási terület a sport. Zermelo (1929) tanulmányát számos olyan cikk követte, mely a gyakorlatban felmerülő különböző problémák megoldására tett kísérletet, Radicchi (2011) például egy tenisz örökranglista felállítását javasolta a PageRank módszer használatával. Más megközelítéssel ugyanerre vállalkozott Temesi et al. (2012). Csató (2013a) a svájci rendszerben megrendezett 2010-es férfi (open) sakkolimpián résztevő csapatok rangsorolását végezte el egy páros összehasonlítási modell segítségével, megmutatva, hogy az alternatív sorrendek több szempontból kedvezőbb tulajdonságokkal rendelkeznek, mint a hivatalos végeredmény. A sportbeli alkalmazások talán legnagyobb előnye között említendő a hatalmas mennyiségben, kis utánajárással elérhető, kevés szubjektív elemet tartalmazó adatok felhasználásának lehetősége. Többek között ez indokolta a 7. fejezetben bemutatott példa kiválasztását is.

\subsection{Páros összehasonlítások egyéni értékelésekből}

A számítástechnika és az internet fejlődése következtében egyre gyakrabban találkozunk olyan nagyméretü adatbázisokkal, ahol egyes szavazók vagy felhasználók különböző alternatívákat értékelnek. Ezek több jellemzőjükben különböznek a társadalmi választások irodalmában megszokott modellektől (Jiang et al., 2011):

1. Nem ordinális, hanem kardinális információt tartalmaznak;

2. A meglevő adatok nagymértékben hiányosak; 
3. Kiegyensúlyozatlanság, az ismert értékelések száma objektumonként / kritériumonként változó;

4. Az adatok valamilyen komplex hálózati struktúrába rendeződnek.

A rendelkezésre álló információk általában egy mátrixban tömöríthetők.

8.1. Definíció. Szavazó-alternatíva mátrix (voter-alternative matrix): Legyen $q_{p i}$ a $p$ döntéshozó $X_{i} \in N$ objektumra vonatkozó számszerü értékelése. Ekkor $Q=\left(q_{p i}\right) \in$ $\in \mathbb{R}^{m \times n}, p=1,2, \ldots, m, i=1,2, \ldots, n$ a szavazó-alternatíva mátrix.

A valós életben előforduló $Q$ mátrixok sokszor nagymértékben hiányosak: a Jiang et al. (2011) által bemutatott Netflix adatbázisban a néző-film mátrix értékeinek 99\%a hiányzik, hiszen az értékelők csak az általuk megnézett néhány müsort pontozzák. Ugyanakkor a filmpárokat tekintve csak azok 0,22\%-a ismeretlen, vagyis alig található két olyan film, melyeket egyszerre nem látott (értékelt) volna valaki.

Eddigi tárgyalásunknak megfelelőn az alternatívák rangsorolására törekszünk, az egyéni $R^{(p)}$ páros összehasonlítási mátrixok hiányzó elemeinek megadása nélkül. Egy másik megközelítést jelentene az, ha először az ismeretlen páros összehasonlításokat becsülnénk meg, majd az így kapott körmérkőzéses probléma alapján állítanánk fel a sorrendet. Előbbi bizonyos szempontból egyszerübb, közvetlenebb megoldásnak tünik, bár a második esetben a rangsorolási módszer kiválasztása viszonylag könnyen kezelhető, ahogy az az axiomatikus tárgyalásból kiderült, ezért igazából a hiányzó $r_{i j}^{(p)}$ elemek kiszámítása jelent kihívást.

A $Q$ szavazó-alternatíva mátrixból a következő módon építhető fel egy rangsorolási probléma. Az $N$ objektumhalmaz elemei a $Q$ mátrix oszlopainak felelnek meg. Az $M$ mérkőzésmátrixban $m_{i j}$ azon szavazók száma, akik egyaránt értékelték az $X_{i} \in$ $\in N$ és $X_{j} \in N$ alternatívákat. Természetesen ezúttal is lehetőség van a súlyozás megváltoztatására.

A nyers adatokból többféle eljárással kaphatjuk meg a ferdén szimmetrikus $A$ eredménymátrixot. Jiang et al. (2011) négy különböző lehetőséget említ:

1. Számtani közép:

$$
a_{i j}=\sum_{p=1}^{m} \frac{q_{p i}-q_{p j}}{m_{i j}},
$$

ha $m_{i j} \neq 0$, ellenkező esetben $a_{i j}=0$. Ez a transzformáció eltolás invariáns, $a_{i j}$ nem változik, amennyiben $Q$ valamelyik oszlopához egy konstanst adunk, vagyis a szavazó skálájának nullpontja eltolódik.

2. Mértani közép:

$$
a_{i j}=\sum_{p=1}^{m} \frac{\log q_{p i}-\log r_{p j}}{m_{i j}}
$$


ha $m_{i j} \neq 0$, ellenkező esetben $a_{i j}=0$. Ez a transzformáció skála invariáns, $a_{i j}$ nem változik, amennyiben $Q$ valamelyik oszlopát egy (pozitív) konstanssal szorozzuk meg, tehát a szavazó skálája arányosan megnő vagy lecsökken.

3. Bináris összehasonlítás:

$$
a_{i j}=\operatorname{Pr}\left(p: q_{p i}>r_{p j}\right)-\operatorname{Pr}\left(p: q_{p i}<r_{p j}\right)
$$

azaz az $X_{i}$ jobb $X_{j}$-nél, illetve ennek komplementer eseménye bekövetkezési valószínűségeinek különbsége. Ez $Q$ oszlopainak tetszőleges monoton transzformációjára invariáns.

4. Logaritmikus arány:

$$
a_{i j}=\log \frac{\operatorname{Pr}\left(p: q_{p i} \geq q_{p j}\right)}{\operatorname{Pr}\left(p: q_{p i} \leq q_{p j}\right)},
$$

azaz a valószínüségek arányának logaritmusa. Ez szintén invariáns $Q$ oszlopainak tetszőleges monoton transzformációira.

\subsection{Megoldási keret a felmerülő problémákhoz}

Amint azt a 7. fejezetben láthattuk, az alkalmazások egyik központi kérdése, hogy a páros összehasonlítások ismert kimenetelei pontosan milyen $(N, A, M) \in \mathcal{R}^{n}$ rangsorolási problémát eredményeznek. Többnyire az összehasonlítások száma, az $M$ mérkőzésmátrix megadása jelenti a kisebb problémát: például egy svájci rendszerü versenynél nyilvánvaló, hogy a lejátszott mérkőzések mindegyike azonosan egy súllyal szerepel, míg a többi alternatívapár esetén az összehasonlítások hiányoznak. Ilyen esetekben aligha vitatható az

$$
m_{i j}= \begin{cases}\text { azon } 1 \leq p \leq m \text { indexek száma, melyekre } r_{i j}^{(p)}+r_{j i}^{(p)}=1 & \text { ha } i \neq j \\ 0 & \text { ha } i=j .\end{cases}
$$

választás, noha itt is megváltoztatható a súlyozás, amennyiben valamilyen exogén információ ezt indokolttá teszi.

A többszörös összehasonlítások megjelenése számos megfontolásból adódhat:

- Tudománymetriai vizsgálatoknál azért, mert a vizsgált időszak alatt tetszőleges számú hivatkozás születhet egy adott cikkre vagy folyóiratra;

- Nemzetközi árszínvonal-összehasonlításnál a termékkosarak eltérése tükrözheti a Fisher-index megbízhatóságát (Rao és Timmer, 2003);

- A sportbajnokságok, szavazások vagy pszichológiai vizsgálatok gyakran $m$ számú fordulóra bonthatók, melyek mindegyikében egy adott objektum leg- 
feljebb egyszer kerül összehasonlításra. Ilyenkor logikus választásnak tünik az ezek kimeneteleit leíró $R^{(p)}, p=1,2, \ldots, m$ mátrixok olyan megválasztása, hogy $r_{i j}^{(p)}+r_{j i}^{(p)}=1$ teljesüljön, amennyiben az $X_{i}$ és $X_{j}$ objektumok összehasonlításra kerültek, illetve $r_{i j}^{(p)}+r_{j i}^{(p)}=0$, ha nem.

Többnyire ekkor is az általunk használt, aggregált $R=\sum_{p=1}^{m} R^{(p)}$ mátrixot szokás vizsgálni, az általános $f: \mathcal{R}_{*}^{n} \rightarrow \mathbb{R}^{n}$ pontozási eljárás helyett (González-Díaz et al., 2014). Ez nem véletlen, hiszen Chebotarev és Shamis (1999) bizonyítja, hogy egyetlen, az egyéni $R^{(p)}$ mátrixokon alapuló rangsoroló eljárás sem elégíti ki az önkonzisztens monotonitás axiómáját (Chebotarev és Shamis, 1997; Csató, 2013c), ha az alternatívapárok közötti összehasonlítások száma nem azonos.

Temesi et al. (2012) tenisz örökranglista felállítására tett kísérletet a legjobb játékosok egymás elleni mérkőzései alapján. Utóbbiak száma tükrözheti a páros összehasonlítás megbízhatóságát, a cikk azonban eltekintett ettől. Az ok elsősorban az adatokban keresendő: például egy megfigyelt 16 : 0-s egymás elleni mérleg azt jelentené, hogy a súlyozott esetben óriási jelentősége lenne ennek a tökéletes, más játékosok számára lényegében megismételhetetlen dominanciának. Ehelyett az egyik változatban az $A$ eredménymátrixon keresztül került beépítésre ez az információ.

Az összehasonlítások számának meghatározása után még mindig hátravan azok kimenetelének definiálása. Erre számtalan stratégia választható, mindenesetre célszerü több lehetséges kódolást párhuzamosan vizsgálni, majd összevetni egymással. Például Csató (2013a) szerint a 2010-es sakkolimpia eredményeiből kapott sorrend nem érzékeny a különböző intenzitású győzelmek matematikailag elfogadható (monoton) transzformációira. Optimális esetben, a rangsorolási eljárások axiomatikus tulajdonságainak figyelembevételével, lehetőség nyílik a gyakorlati példa eredményeinek elméletileg alátámasztható átkódolására is, ahogy azt a 7. fejezetben bemutattuk (lásd még Csató (2012b)).

Telcs et al. (2013a) a felvételizők preferenciái alapján végezte el felsőoktatási intézmények rangsorolását: az utóbbiak közötti páros összehasonlítások kimenetele a beadott jelentkezési lapok révén adható meg. Az azonban korántsem egyértelmü, vajon mikor mondhatjuk azt, hogy az egyik egyetem egyértelmüen jobb a másiknál. A cikk az alábbi feltételezésekkel élt:

1. Nincs különbség a preferenciák erőssége között;

2. A közvetett preferenciák is számítanak (az első helyen megjelölt intézmény jobb a harmadiknál, negyediknél stb.);

3. A megjelölt szakok preferáltak az összes kihagyotthoz képest - A nem megjelölt szakok kevésbé preferáltak, mint bármelyik megjelölt (Telcs et al., 2013a, 294. о.); 
4. A nem megjelölt szakok egyenrangúak, a viszonyuk döntetlennek minősül.

Ezek közül az első kettő aligha vitatható. A harmadik pont tekintetében már inkább indokolt az óvatosság. Több ok is visszatarthat egy felvételizőt az általa legjobbnak gondolt szak megjelölésétől, például a további szakokra történő jelentkezés pénzbeli (és adminisztratív) költségei, a magas ponthatárok miatt számára eleve elérhetetlen helyek kihagyása, vagy az egyetemre járás járulékos kiadásainak (szállás, étkezés) nagysága. Emiatt Avery et al. (2013) hasonló vizsgálata az intézmények közötti preferenciákat csak a megadott választási halmazon belül értelmezi, valamelyik szakot akkor tekinti jobbnak egy másiknál, ha előrébb szerepel a felvételiző jelentkezési lapján.

Végül a negyedik feltevés, a nem megjelölt objektumok egyenrangúként besorolását mellőzve - a hiányzó összehasonlítások megengedésével - célszerű lehet a két objektum összehasonlításának eredményét ismeretlennek tekinteni, $r_{i j}^{(p)}=r_{j i}^{(p)}=0,5$ helyett a $r_{i j}^{(p)}=r_{j i}^{(p)}=0$ definíciót alkalmazni.

A gyakorlati alkalmazások egyik központi kérdése tehát a valóságból származó megfigyelések matematikai nyelvre fordítása. A páros összehasonlítási feladatok rangsorolási problémaként való megoldásában az alábbi lépések követését ajánljuk:

1. A matematikai módszerek alkalmazhatóságának ellenőrzése: ha a kiválasztott objektumok képesek befolyásolni a páros összehasonlítások eredményét, ösztönözve voltak-e a minél jobb eredmény elérésére;

2. Az egyes objektumpárokra elvégzett összehasonlítások száma, az $M$ mérkőzésmátrix megadása;

3. A páros összehasonlítások kimenetelének kódolása, az $A$ eredménymátrix definiálása;

4. A pontozási eljárás kiválasztása az axiomatikus megközelítés tükrében;

5. A sorrendek érzékenységvizsgálata a kiinduló hipotézisek szempontjából;

6. Az eredmények elemzése, összehasonlítása az ismert rangsorokkal.

A folyamat természetesen nem egyirányú. Az adatok vizsgálata rámutathat a kiinduló feltevés, a matematikai kódolás, vagy a kiválasztott pontozási módszerek hibáira, korlátaira, az összehasonlítások súlyozása sem mindig függetleníthető azok kimenetelének meghatározásától (Temesi et al., 2012). A keret néha szűkíthető is, statisztikai jellegű vizsgálatokban például az első lépés értelemszerűen kimarad. 


\section{4. Összegzés}

A fejezetben a páros összehasonlítások gyakorlati alkalmazásaival foglalkoztunk. A 8.1. alfejezetben bemutattuk ezek használatát a statisztika (EKS-módszer), a tudománymetria, a pszichológia, a szavazáselmélet, és a sport területén. Ezt követően bevezettük a termékértékelések matematikai kezelését lehetővé tevő szavazó-alternatíva mátrix fogalmát (8.2. alfejezet). Ebből kiindulva tárgyaltuk a hasonló feladatok rangsorolási problémaként való kezelését, az eredménymátrix felírásának fóbb koncepcióit. Végül a 8.3. alfejezetben egy keretet adtunk a páros összehasonlítások alapján történő rangsorolásra. Kitértünk a hiányzó és többszörös összehasonlítások kezelésére, illusztrációként pedig különböző cikkekből vettünk példákat. Ezenkívül javaslatot tettünk az ilyen feladatok megoldásának lépéseire.

Ebben a fejezetben nem szerepeltek módszertani szempontból értékelhető eredménynek. Ugyanakkor fontosnak tartjuk az alkalmazási területek összegyüjtését, például tudomásunk szerint eddig sehol sem jelent meg a páros összehasonlítások statisztikai felhasználása, az EKS-módszer és a legkisebb négyzetek ekvivalenciája. Úgy gondoljuk, a megfogalmazott ajánlások nagymértékben segíthetik a gyakorlati felhasználók munkáját, alapos megfontolásuk segítségével elkerülhetők az elméleti oldalról támadható hiányosságok. Ennek jelentőségére felhívjuk az olvasó figyelmét a Telcs et al. (2013a) cikkre, az erre adott reakciónkra (Csató, 2013d) és a viszontválaszra (Telcs et al., 2013b). 


\section{9. fejezet}

\section{Összefoglalás}

Sero venientibus ossa.

Latin közmondás

A bevezetésben két célt tűztünk magunk elé: egyrészt a gyakorlatban felmerülö, páros összehasonlítások alapján történő rangsorolást megkívánó feladatok matematikai kezelésének leírását, másrészt az ezek megoldására alkalmas módszerek bemutatását, csoportosítását és értékelését. Előbbivel a 7. és a 8., utóbbival a 26. fejezetben foglalkoztunk; ennek megfelelően eredményeinket fordított sorrendben összegezzük.

A 2. fejezetben a páros összehasonlítások egy általános matematikai modelljét ismertettük. A rangsorolási problémát kétféleképpen reprezentáltuk. Az egyik a korábbról ismert aggregált páros összehasonlítási mátrixot (Chebotarev és Shamis, 1998a; González-Díaz et al., 2014) használja, ezt a takarékos változatot elsősorban a számítógépes szimulációk elvégzéséhez ajánljuk (néhány, az 5. fejezetben található ellenpéldát is ilyen úton találtunk meg). Több, a disszertációban nem tárgyalt módszer (invariáns, fair bets, maximum likelihood) szintén ebből indul ki. A másik esetben ugyan külön eredménymátrix és mérkőzésmátrix szerepel, de ezek ferdén szimmetrikus, illetve szimmetrikus volta miatt az információigény természetesen változatlan. Ez a definíció fóként a megértést, valamint a későbbiekben részletesen tárgyalt módszerek és bizonyos tulajdonságok bevezetését segíti.

Kitértünk a két rangsorolási megközelítésre, a lineáris rendezéssel való közelítésre és a pontozási eljárások alkalmazására, melyek közül az irodalomban elhangzó érvek - elsősorban Bouyssou (2004) - alapján az utóbbiak használata mellett érveltünk. Néhány ilyet a 3. fejezetben ismertettünk. Kiemelt figyelmet fordítottunk az általánosított sorösszegre és a legkisebb négyzetek módszerére: ezekre a 4. fejezetben egy új gráf interpretációt adtunk. Ez sem lett volna lehetséges az eredmény- és mérkőzésmátrixok megkülönböztetése nélkül. 
A következő két fejezetben absztraktabb nézőpontra tértünk át, González-Díaz et al. (2014) nyomán különböző axiómákat definiáltunk, majd megvizsgáltuk, hogy a pontszám, az általánosított sorösszeg és a legkisebb négyzetek módszere teljesíti-e azokat.

\section{1. ábra. Az 5. fejezetben tárgyalt axiómák kapcsolata}

A nyilak implikációt jeleznek. Néhány esetben több tulajdonságból következik egy újabb, például $N E U+S Y M+C S \Rightarrow I I M$. A 9.1. ábra piros, szaggatott körvonalú csúcsai az általunk bevezetett axiómákat; kék folytonos vonalak saját eredményeinket; fekete, szaggatott vonalak a triviális vagy korábbról ismert összefüggéseket jelölik. A zöld, pontozott vonal egy speciális kapcsolatot jelenít meg (lásd a szövegben).

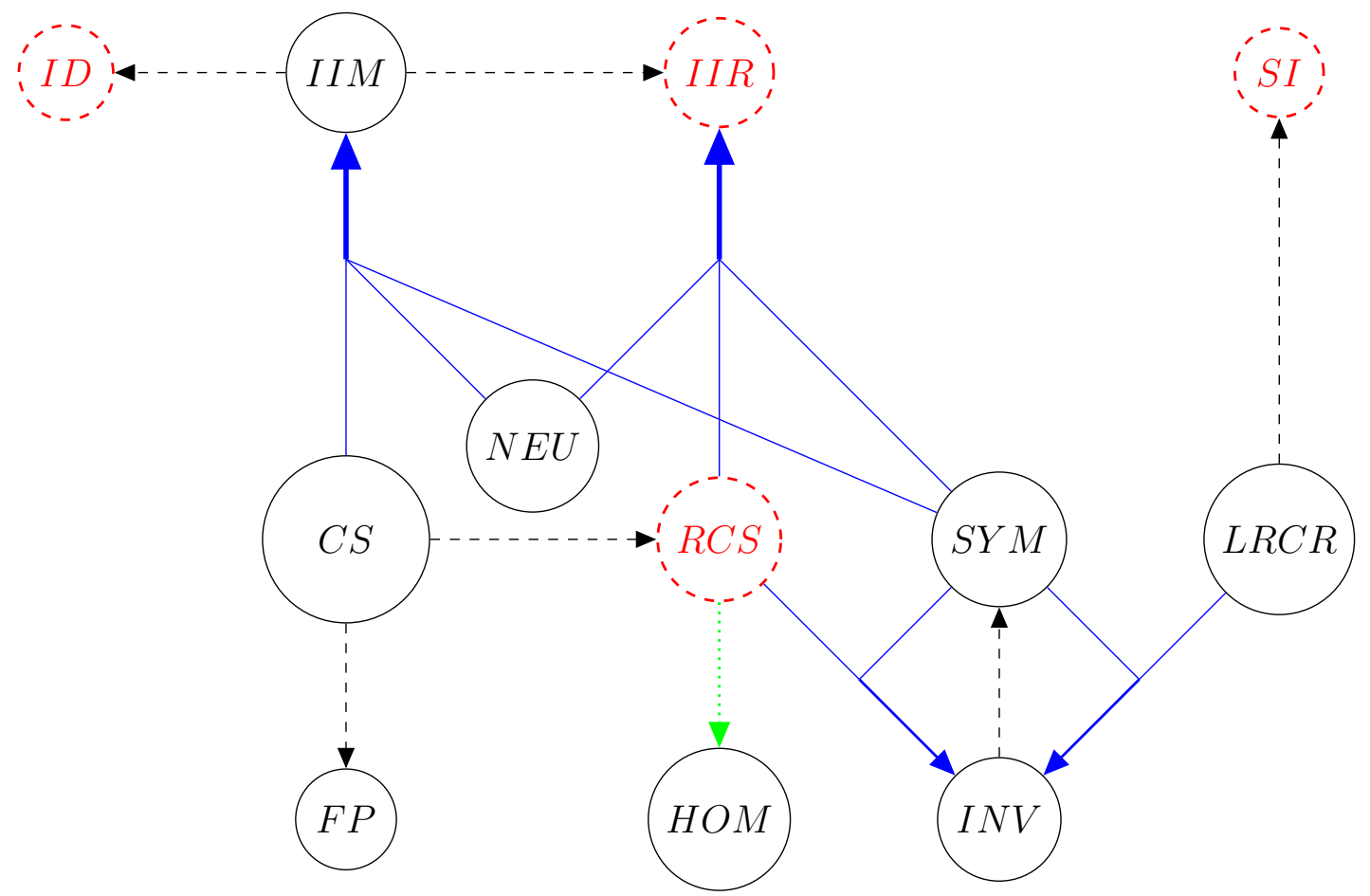

Az 5. fejezetben szereplő axiómák egymáshoz való viszonyát a 9.1. ábra mutatja (lásd még F.V. Függelék F.7. táblázatát). A homogenitás (HOM) csak részben következik az eredmény konzisztenciából $(R C S)$, a kapcsolat teljes feltárása további kutatást igényel - mindenesetre a közös gyökerekre utal, hogy az általánosított sorösszeg mindkettőt csak bizonyos $\varepsilon$ paraméterek esetén teljesíti. ${ }^{36}$

A 6. fejezetben a pontszám módszer egy karakterizációját (Bouyssou, 1992) vizsgáltuk meg, majd beláttuk, hogy modellünkben nem érvényes, mert az ehhez szükséges axiómákat az általánosított sorösszeg és a legkisebb négyzetek módszere egyaránt teljesíti. Az ismert és újonnan bevezetett tulajdonságok alapján elemeztük a pontszám módszerrel való kapcsolatot, ami az alkalmazások szempontjából lehet lényeges.

36 A 9.1. ábrán zöld, pontozott vonallal jelölve. A HOM tulajdonság biztosan nem ekvivalens az $R C S$-sel, mert a fair bets pontozási eljárás csupán az előbbit elégíti ki (Csató, 2014b). 
Axiomatikus eredményeink - González-Díaz et al. (2014, Table 1) mintájára a 9.1. táblázatban tanulmányozhatók; az F.V. Függelék további részleteket közöl ezekről. Az elemzés során összegyüjtöttük az irodalomban definiált tulajdonságokat (bizonyos esetekben apróbb módosításokkal, kiegészítésekkel), emellett hat új követelményt vezettünk be: ezek a skála invariancia $(S I)$, az eredmény konzisztencia $(R C S)$, a lineáris rendezés megőrzése $(L O P)$, a függetlenség az irreleváns eredményektől $(I I R)$, a függetlenség a döntetlenektől (ID) és az ellenfelek homogén kezelése (HTO). A pontszám az LOP tulajdonság kivételével ugyan mindegyiket kielégíti, azonban láttuk, hogy hiányzó és többszörös összehasonlítások jelenlétében az irreleváns mérkőzésektől való függetlenség $(I I M)$ teljesülése nem kívánatos. Egyik fontos állításunk szerint ez lényegében kizárja az összeadhatóság fennállását is, indokolva az eredmény konzisztencia bevezetését, az eredmény- és mérkőzésmátrixok megkülönböztetését.

9.1. táblázat. Pontozási eljárások axiomatikus összehasonlítása

\begin{tabular}{|c|c|c|c|c|c|}
\hline Tulajdonság & Név & Egyenlő & Pontszám $^{\dagger}$ & $\begin{array}{c}\text { Ált. } \\
\text { sorösszeg }\end{array}$ & $\begin{array}{l}\text { Legkisebb } \\
\text { négyzetek }\end{array}$ \\
\hline$(A N O)$ & $\checkmark$ & $\checkmark$ & $(\checkmark)$ & $(\checkmark)$ & $(\checkmark)$ \\
\hline$(N E U)$ & $x$ & $\checkmark$ & $(\checkmark)$ & $(\checkmark)$ & $(\mathcal{V})$ \\
\hline$(C N T)$ & $x$ & $\checkmark$ & $(\mathcal{U})$ & $(\boldsymbol{V})$ & $(\checkmark)$ \\
\hline$(L R C R)$ & $x$ & $\checkmark$ & $\checkmark$ & $(\boldsymbol{V})$ & $\checkmark$ \\
\hline$(H O M)$ & $\checkmark$ & $\checkmark$ & $(\boldsymbol{V})$ & $(\boldsymbol{V}) x^{*}$ & $(\boldsymbol{V})$ \\
\hline$S I$ & $\checkmark$ & $\checkmark$ & $\checkmark$ & $\checkmark$ & $\checkmark$ \\
\hline$(C S)$ & $\checkmark$ & $x$ & $(\boldsymbol{V})$ & $(x)$ & $(x)$ \\
\hline$(F P)$ & $\checkmark$ & $\checkmark$ & $(\checkmark)$ & $(\boldsymbol{V})$ & $(\boldsymbol{V})$ \\
\hline$R C S$ & $\checkmark$ & $x$ & $\checkmark$ & $\checkmark x^{*}$ & $\checkmark$ \\
\hline$(S Y M)$ & $x$ & $\checkmark$ & $(\boldsymbol{V})$ & $(\boldsymbol{V})$ & $(\boldsymbol{V})$ \\
\hline$(I N V)$ & $x$ & $\checkmark$ & $(\boldsymbol{\nu})$ & $(\boldsymbol{V})$ & $(\checkmark)$ \\
\hline$L O P$ & $x$ & $x$ & $x$ & $x$ & $x$ \\
\hline$(I I M)$ & $\checkmark$ & $\checkmark$ & $(\checkmark)$ & $(x)$ & $(x)$ \\
\hline$I I R$ & $\checkmark$ & $\checkmark$ & $\checkmark$ & $x$ & $x$ \\
\hline$I D^{\diamond}$ & $\checkmark$ & $\checkmark$ & $\checkmark$ & $\checkmark$ & $\checkmark$ \\
\hline$(S M)$ & $x$ & $x$ & $(\checkmark)$ & $(\boldsymbol{V})$ & $(x)$ \\
\hline$(C S M)$ & $x$ & $x$ & $(\checkmark)$ & $(\checkmark)$ & $(x)$ \\
\hline$(I C)$ & $\checkmark$ & $\checkmark$ & $(\checkmark)$ & $\checkmark$ & $\checkmark$ \\
\hline$(S C C)$ & $x$ & $x$ & $(\sqrt{ })$ & $(\checkmark)$ & $(\mathcal{V})$ \\
\hline$(H T V)$ & $x$ & $x$ & $(\boldsymbol{V})$ & $(\boldsymbol{V})$ & $(\boldsymbol{V})$ \\
\hline HTO & $x$ & $x$ & $\checkmark$ & $\checkmark$ & $\checkmark$ \\
\hline
\end{tabular}

Zárójelben a korábban bevezetett axiómák és elért eredmények, a többi saját hozzájárulás

† González-Díaz et al. (2014) tőlünk eltérően definiálja a pontszám módszert; az ott belátottak zárójelben szerepelnek

‡ Általánosított sorösszeg: González-Díaz et al. (2014) csak az $\bar{\varepsilon}=[1 / m(n-2)]$ esetet vizsgálja; az ott belátottak zárójelben szerepelnek

* Az $\varepsilon$ paraméter megválasztásától függ

$\diamond$ Chebotarev (1994, Property 14) dinamikus monotonitás (2) feltételének kiterjesztése 
A homogenitás $(H O M)$ és az eredmény konzisztencia vizsgálata alapján az általánosított sorösszeg használata változó, a mérkőzésszámtól függő paraméter mellett ajánlott; ez az eljárás statisztikai háttere (Chebotarev, 1994) ismeretében talán kevésbé meglepő. Ekkor a legkisebb négyzetek módszerétől elsősorban a monotonitás tekintetében különbözik. ${ }^{37} \mathrm{~A}$ vizsgált pontozási eljárások egyike sem őrzi meg a lineáris rendezést, ami nagy valószínüséggel azok sokkal szélesebb körére (akár az összesre?) is érvényes.

E területen három fó irányt látunk a további kutatás számára. Az első az elemzés kiterjesztése újabb pontozási eljárások bevonásával. A fair bets módszerrel kapcsolatos néhány eredményt két saját munkánkban ismertettünk (Csató, 2013d, 2014b). Emellett ígéretesnek tűnik a Slikker et al. (2012) által digráfok csúcsainak rangsorolására javasolt általános keretrendszer vizsgálata, mely egyik határértékként a fair bets eljárást adja. A pozíciós erő (Herings et al., 2005) bevonását elsősorban a legkisebb négyzetek módszerével közös gráfelméleti gyökerek indokolhatják (Csató, 2014a).

A másik központi témát a bevezetésben már említett karakterizációk jelentik. Az axiomatikus vizsgálat végső célját kétségtelenül ezek megtalálása jelentené, ugyanakkor kérdéses, mennyire várhatunk egzakt eredményeket a tárgyalt általános esetben. Mindenesetre ezen elemzésünket sem tekintjük lezártnak, további adalékokkal szolgál Csató (2013b).

Végül nem feledkezhetünk meg arról a kérdésről sem, mennyire tekinthető megbízhatónak a rangsor, egyáltalán van-e értelme egyértelmü ordinális sorrend felállításának, vagy az adatokban rejlő inkonzisztencia eleve kizárja ezt. Az utóbbi témával például Jiang et al. (2011) foglalkozott, míg az előbbi többnyire statisztikaiökonometriai irányultságú cikkek tárgya. A tárgyalt, matematikailag viszonylag egyszerüen kezelhető keretben megvalósítható lehet a hasonló rangsorok hibabecslése is (Horváth et al., 2013). Ezáltal megadható, hogy az adott eredmények alapján mekkora valószínűséggel előzi meg az egyik rangsorolandó objektum a másikat.

Az első témát itt viszonylag szűkebb terjedelemben tárgyaltuk, ennek egyik oka, hogy más - részben társszerzős - munkáinkban (Csató, 2012a,b, 2013a; Temesi et al., 2012; Csató, 2013c, 2014b) már többször vizsgáltunk hasonló problémákat. Úgy gondoltuk, hasznosabb egyfajta áttekintést adni a páros összehasonlítások fóbb alkalmazási területeiről, konkrét cikkek alapos taglalása helyett inkább csak felvetve az azokban felmerülő problémákat. Ezt a 8. fejezetben tettük meg, ahol tapasztalataink alapján néhány, felhasználóknak szóló tanács megfogalmazására is vállalkoztunk.

A 7. fejezetben részletesen vázoltuk egy potenciális alkalmazás, a svájci rendszerü sakk csapatversenyek rangsorolásának nehézségeit. Először axiomatikus alapokon definiáltunk egy alkalmas modellt, majd rámutattunk az általánosított sorösszeg és a

37 A kérdéshez lásd még González-Díaz et al. (2014); Csató (2013b). 
legkisebb négyzetek módszerének használhatóságára. A javasolt pontozási eljárásokat a 2011-es és 2013-as sakkcsapat Európa-bajnokság példáján keresztül elemeztük. A kapott rangsorok távolságának Can (2014) alapján történő megadásával, sokdimenziós skálázással ábrázoltuk azokat. Értékelésüket három szempont, az előrejelző képesség, a mintailleszkedés, és a robusztusság figyelembevételével hajtottuk végre.

Az alábbi következtetések megalapozhatják a legkisebb négyzetek módszerének alkalmazását a rangsorolásra hasonló versenyek esetén:

- Egyetlen módszer, köztük a hivatalos sorrend sem jobb előrejelző a csapatok a priori értékelését tükröző rangsornál, akkor sem, ha csak a következő forduló eredményeit kell megbecsülni;

- A mintailleszkedés, a korábbi eredmények visszaadásának képessége az $\varepsilon$ paraméter, az ellenfelek szerepének növekedésével javul, a legkisebb négyzetek módszere kismértékben jobb a hivatalosnál;

- A verseny egyes köreinek lejátszása után kapott rangsorok az $\varepsilon$ paraméter, az ellenfelek fontosságának emelkedésével stabilabbá válnak, a legkisebb négyzetek módszere robusztusabb a hivatalos eljárásnál.

Ezen számítások, valamint a homogenitásra és az eredmény konzisztenciára vonatkozó állítások némi adalékkal szolgálnak az általánosított sorösszeg módszer paraméterválasztására vonatkozóan, ezáltal részben választ adunk egy, a 3. fejezet végén felvetett nyitott problémára.

A mérkőzéspontok felé hajló általánosított eredménymátrix (alacsony, 0-hoz közeli ג) használata minél több táblapont gyűjtésére ösztönöz, azokhoz képest mégis a mérkőzéspontokat preferálja. Természetesen a két példából levont tapasztalatok nem feltétlenül általános érvényűek, a megfogalmazott ajánlások alátámasztása további megfigyeléseken vagy szimuláción alapuló - vizsgálatokat igényelhet. Mindazonáltal javaslatunk elméleti megfontolásokkal is indokolható.

Összességében úgy véljük, mindkét kitűzött cél kapcsán sikerült lényeges hozzájárulásokkal gazdagítani a rendelkezésre álló ismereteket. A disszertációban nem kívántunk állást foglalni a két kérdés fontossága, egymáshoz való viszonya tekintetében, ezt talán helyesebb az olvasóra bízni. Ugyanakkor későbbi kutatásaink során megfontolandónak tartjuk az alkalmazásokból, problémákból kiindulva, azok segítségével megfogalmazni a feladatot, kiválasztani a megfelelő módszereket. Ez bizonyos mértékben megoldást kínálhat a hiányzó karakterizációk okozta nehézségekre is. 


\section{Függelékek}

\section{Tartalomjegyzék}

F.I. Függelék: A reguláris páros összehasonlítási multigráf esete . . . . . 132

F.II. Függelék: Lineáris rendezések távolsága . . . . . . . . . . . . . . . . 137

F.III. Függelék: Sakkcsapat EB-k eredményei és rangsorai . . . . . . . . . 143

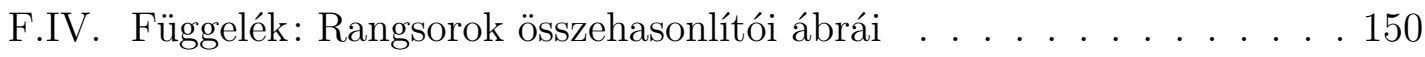

F.V. Függelék: Axiómák összefoglaló táblázatai . . . . . . . . . . . . . . 153

\section{Ábrák jegyzéke}

F.1. Az F.I.1. Példa rangsorolási problémája . . . . . . . . . . . . . . . . . 132

F.2. Az F.I.1. Példa q értékelővektorának közelítése . . . . . . . . . . . . . 133

F.3. Az F.I.2. Példa rangsorolási problémája . . . . . . . . . . . . . . . . . 134

F.4. Az F.I.2. Példa q értékelővektorának közelítése . . . . . . . . . . . . . 135

F.5. Következő forduló előrejelző képessége, 2013-as sakkcsapat EB . . . . 151

F.6. Stabilitás a fordulók között, 2013-as sakkcsapat EB . . . . . . . . . . 152

\section{Táblázatok jegyzéke}

F.1. A 2011-es sakkcsapat Európa-bajnokság eredményei . . . . . . . . . . 144

F.2. A 2013-as sakkcsapat Európa-bajnokság eredményei . . . . . . . . . . 146

F.3. A 2011-es sakkcsapat Európa-bajnokság rangsorai . . . . . . . . . . . 148

F.4. A 2013-as sakkcsapat Európa-bajnokság rangsorai . . . . . . . . . . . 149

F.5. Fogalmak és pontozási eljárások . . . . . . . . . . . . . . . . . . 153

F.6. Pontozási eljárások az axiómák tükrében . . . . . . . . . . . . . . . 155

F.7. Tulajdonságok kapcsolata . . . . . . . . . . . . . . . . . 157 


\section{F.I. Függelék: A reguláris páros összehasonlítási multigráf esete}

A 4.2.1. alfejezet fő eredménye, a 4.2. Tétel nem érvényes reguláris páros összehasonlítási multigráfra. A következőkben ezzel az esettel foglalkozunk, mely terjedelmi okokból a Csató (2014a) tanulmányban sem szerepel.

Ekkor a 2.2. Lemma értelmében az $M$ mérkőzésmátrix blokk antidiagonális, létezik az alábbi partíciója

$$
M=\left(\begin{array}{ll}
O_{n_{1} \times n_{1}} & M_{n_{1} \times n_{2}}^{1} \\
M_{n_{2} \times n_{1}}^{2} & O_{n_{2} \times n_{2}}
\end{array}\right) .
$$

Az $N=U \cup V$ felbontásban $|U|=|V|$, hiszen $G$ reguláris és páros volta miatt a két halmaz objektumai fokszámának összege megegyezik, tehát $n$ páros. A Neumann-sor ugyan nem konvergens, azonban a $B$ mátrix problémát okozó $\lambda=-1$ sajátértéke az egységkör határán található, ezért a sor korlátos és oszcillál.

F.1. ábra. Az F.I.1. Példa rangsorolási problémája

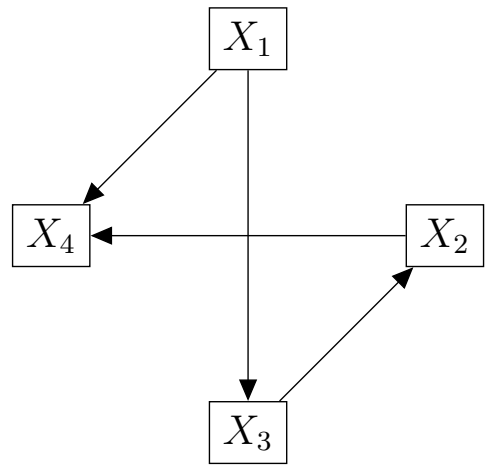

F.I.1. Példa. Tekintsük az $(N, A, M) \in \mathcal{R}_{U}^{4}$ súlyozatlan rangsorolási problémát (F.1. ábra), ahol:

$$
A=\left[\begin{array}{cccc}
0 & 0 & 1 & 1 \\
0 & 0 & -1 & 1 \\
-1 & 1 & 0 & 0 \\
-1 & -1 & 0 & 0
\end{array}\right] \quad \text { és } \quad M=\left[\begin{array}{llll}
0 & 1 & 1 & 0 \\
1 & 0 & 0 & 1 \\
1 & 0 & 0 & 1 \\
0 & 1 & 1 & 0
\end{array}\right]
$$

A $G$ összehasonlítási multigráf 2-reguláris $\left(d_{i}=2\right.$ minden $X_{i} \in N$-re) és páros az $U=\left\{X_{1}, X_{2}\right\}, V=\left\{X_{3}, X_{4}\right\}$ választással. Az iteráció különböző lépéseiben kapott értékelővektorok az F.2. ábrán láthatók.

A pontszám módszer az $X_{1} \succ\left(X_{2} \sim X_{3}\right) \succ X_{4}$ rangsort adja, a második helyen $X_{2}$ és $X_{3}$ között holtversennyel. Az ellenfelek erejének figyelembevételével a sorrend $\left(X_{1} \sim X_{3}\right) \succ\left(X_{2} \sim X_{4}\right)$, döntetlennel az első és harmadik pozíciókban. 
F.2. ábra. Az F.I.1. Példa q értékelővektorának közelítése

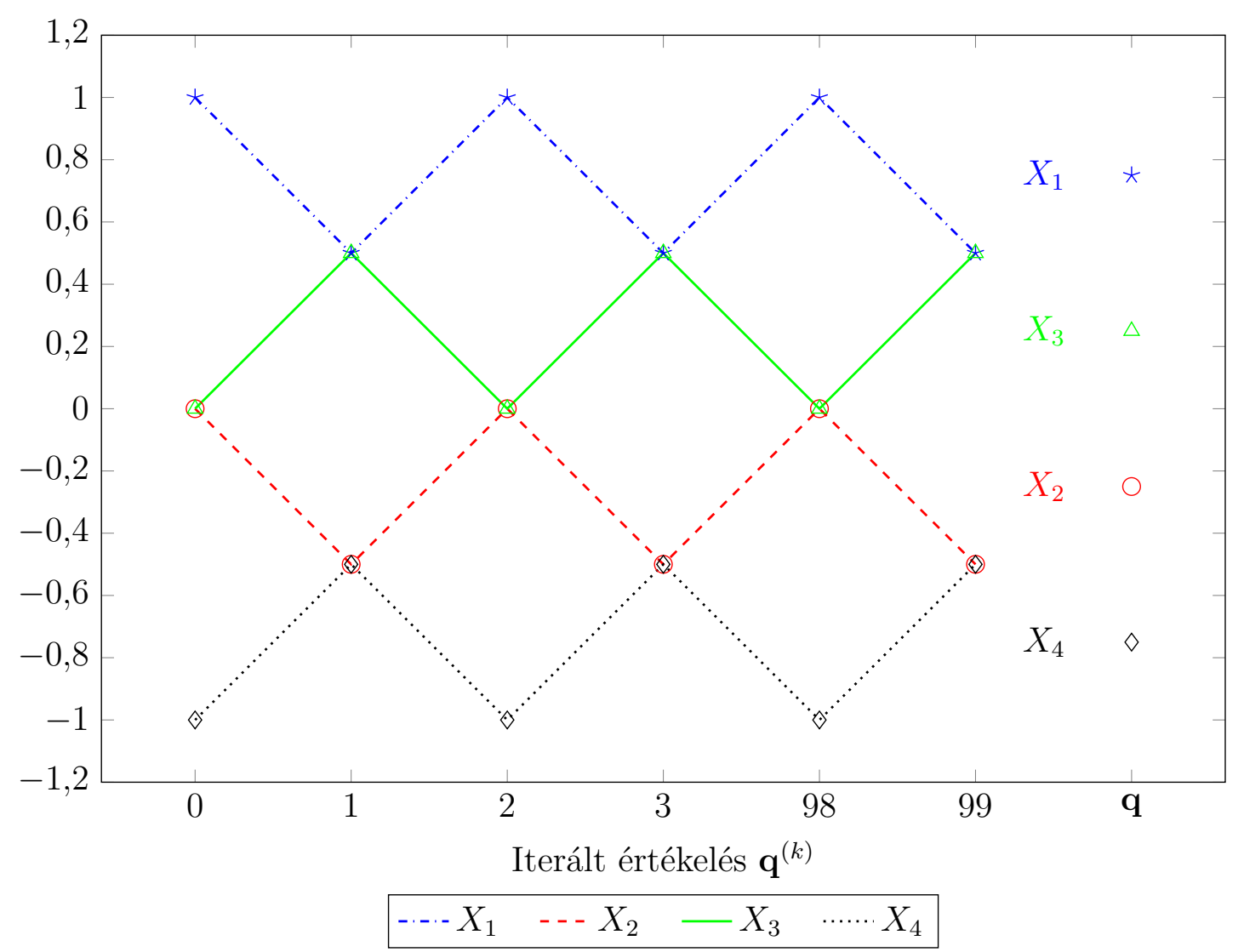

Minden páros, illetve páratlan számú iterációt követően ez a két rangsor fordul elő, a Neumann-soros felbontás nem konvergál, hanem a $\mathbf{q}^{(0)}$ és $\mathbf{q}^{(1)}$ vektorok között oszcillál. A legkisebb négyzetek módszerének q értékelővektora éppen ezek számtani közepe, a hozzá tartozó rangsor pedig $X_{1} \succ X_{3} \succ X_{2} \succ X_{4}$, holtverseny nélkül. A probléma oka, hogy az $U$ és $V$ halmazbeli objektumok értékelései csak szimultán módon határozhatók meg.

Ugyanakkor a $G$ összehasonlítási multigráf reguláris páros voltának kizárása csupán a Neumann-sor konvergenciájának elégséges, nem szükséges feltétele: léteznek olyan esetek, amikor a végső értékelés ennek ellenére megkapható az iterációból, például, ha $\mathbf{s}=\mathbf{0}$. Ez tetszőleges $M$ mérkőzésmátrix esetén előfordulhat, vagyis a konvergencia kérdése nem szükíthető le egyedül ennek vizsgálatára.

6. Sejtés. Legyen $(N, A, M) \in \mathcal{R}^{n}$ egy rangsorolási probléma. A 4.2. Tétel állitása akkor és csak akkor érvényes, ha az összehasonlítási multigráf nem reguláris páros $\operatorname{vagy} \mathbf{s}=\mathbf{0}$.

Az F.I.1. Példa a 6. Sejtéssel együtt sem mutatja meg az összes lehetséges esetet. Az alábbi példa szerint megtörténhet, hogy egy nem konvergens iteráció nem két állapot között oszcillál. 
F.3. ábra. Az F.I.2. Példa rangsorolási problémája

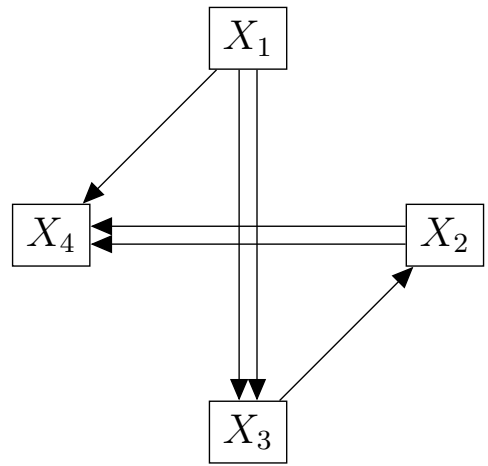

F.I.2. Példa. Tekintsük az $(N, A, M) \in \mathcal{R}_{U}^{4}$ súlyozatlan rangsorolási problémát (F.2. ábra), ahol:

$$
A=\left[\begin{array}{cccc}
0 & 0 & 2 & 1 \\
0 & 0 & -1 & 2 \\
-2 & 1 & 0 & 0 \\
-1 & -2 & 0 & 0
\end{array}\right] \quad \text { és } \quad M=\left[\begin{array}{llll}
0 & 1 & 2 & 0 \\
1 & 0 & 0 & 2 \\
2 & 0 & 0 & 1 \\
0 & 2 & 1 & 0
\end{array}\right] \text {. }
$$

A $G$ összehasonlítási multigráf 3-reguláris $\left(d_{i}=3\right.$ minden $X_{i} \in N$-re) és páros az $U=\left\{X_{1}, X_{2}\right\}, V=\left\{X_{3}, X_{4}\right\}$ választással. Az iteráció különböző lépéseiben kapott értékelővektorok az F.4. ábrán láthatók.

A pontszám módszer az $X_{1} \succ X_{2} \succ X_{3} \succ X_{4}$ rangsort adja, holtverseny nélkül. $\mathrm{Az}$ ellenfelek erejének figyelembevételével a sorrend $\left(X_{1} \sim X_{3}\right) \succ\left(X_{2} \sim X_{4}\right)$, döntetlennel az első és harmadik pozíciókban. Minden páros, illetve páratlan számú iterációt követően ez a rangsor érvényes, a feladat mégsem azonos az F.I.1. Példában megfigyelt esettel, hiszen most módosulnak az értékelővektorok. A lépések számának növekedésével viszont egyre stabilabbá válnak, $\mathbf{q}^{(97)} \approx \mathbf{q}^{(99)}$ és $\mathbf{q}^{(98)} \approx \mathbf{q}^{(100)}$, a legkisebb négyzetek módszerének $\mathbf{q}$ megoldása pedig közelítőleg $\mathbf{q}^{(98)}$ és $\mathbf{q}^{(99)}$ számtani közepe.

7. Sejtés. A páros, illetve páratlan számú lépéseket követöen kapott értékelövektoroknak akkor is létezik határértékük, ha egy $G$ reguláris páros összehasonlítási multigráf esetén a

$$
\begin{gathered}
\mathbf{q}^{(0)}=(1 / \mathfrak{d}) \mathbf{s}, \\
\mathbf{q}^{(k)}=\mathbf{q}^{(k-1)}+\frac{1}{\mathfrak{d}}\left(\frac{1}{\mathfrak{d}} C\right)^{k} \mathbf{s}, \quad k=1,2, \ldots
\end{gathered}
$$

sorozat nem konvergens. A legkisebb négyzetek módszerének $\mathbf{q}$ megoldása a két határérték számtani átlaga.

Formálisan, tetszóleges $\mu>0$-hoz létezik olyan $t \in \mathbb{N}$, hogy

$$
\left\|\mathbf{q}^{(2 z+2)}-\mathbf{q}^{(2 z)}\right\|_{2}<\mu
$$


F.4. ábra. Az F.I.2. Példa q értékelővektorának közelítése

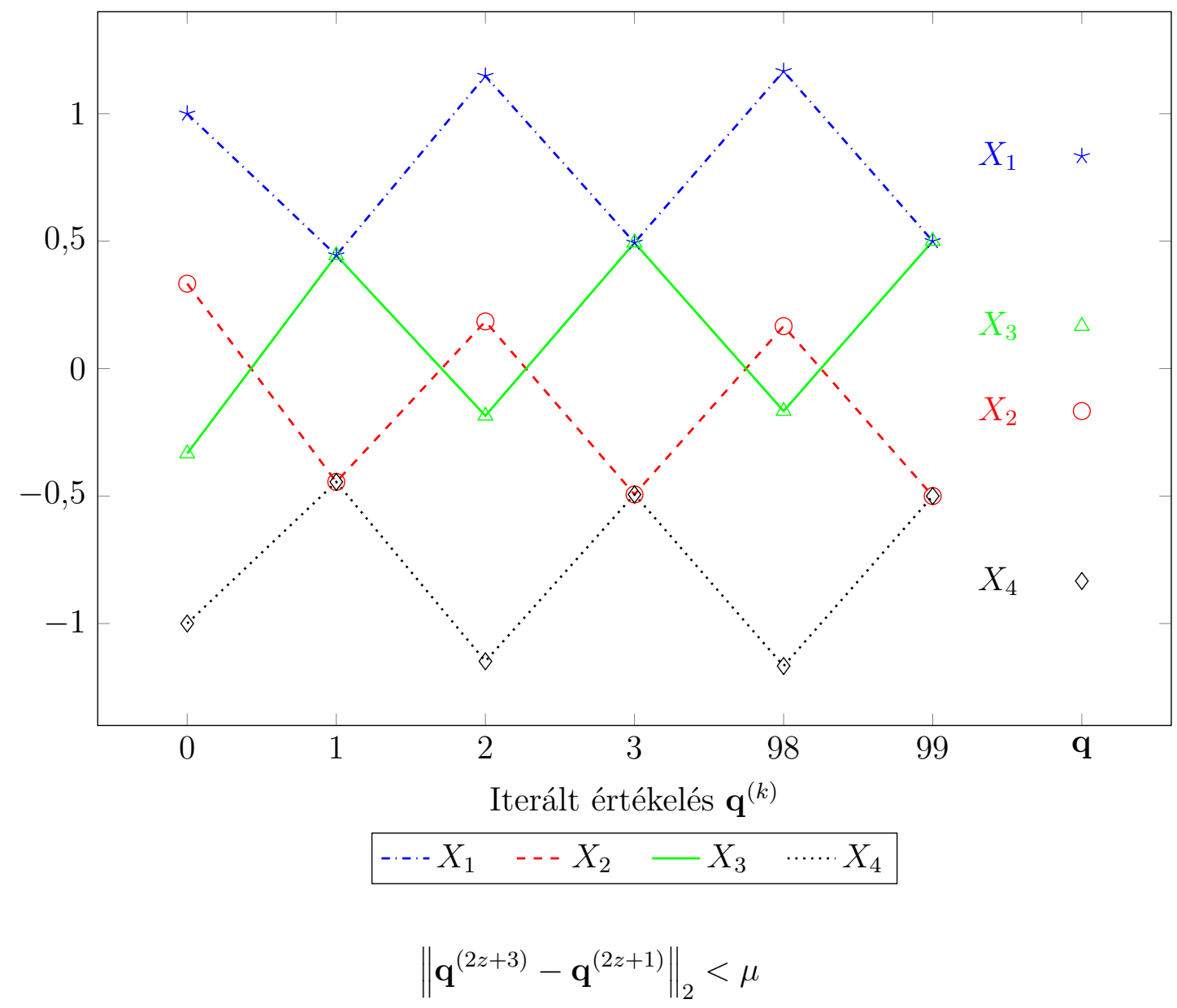

és

$$
\left\|\mathbf{q}-\frac{\mathbf{q}^{(2 z+1)}+\mathbf{q}^{(2 z)}}{2}\right\|_{2}<\mu,
$$

minden $z \geq t, z \in \mathbb{N}$ mellett.

A q vektor felbontásával kapcsolatban a 4.2. Tétel mellett az alábbi nyitott kérdések merülnek fel.

1. Probléma. Igaz-e, hogy egy $G$ reguláris páros összehasonlítási multigráf esetén három eset lehetséges:

I. a $\mathbf{q}^{(k)}$ iterált értékelővektorok akkor és csak akkor változatlanok, ha $\mathbf{s}=\mathbf{0}$ (lásd a 6. Sejtést);

II. a $\mathbf{q}^{(k)}$ iterált értékelővektorok 2 periódussal ismétlődnek, vagyis $\mathbf{q}^{(k)}=\mathbf{q}^{(k+2)}$ minden $k \in \mathbb{N}$-ra (lásd az F.I.1. Példát);

III. a $\mathbf{q}^{(k)}$ iterált értékelővektorok páros és páratlan $k \in \mathbb{N}$ esetén külön-külön konvergálnak (lásd az F.I.2. Példát és a 7. Sejtést)? 
Ha a válasz pozitív, teljesül-e, hogy a legkisebb négyzetek módszerének q megoldása a páros és páratlan $k \in \mathbb{N}$-ekre kapott értékelővektorok (a II. esetben), illetve ezek határértékeinek (a III. esetben) számtani közepe?

Hogyan karakterizálhatók az I., a II. és a III. pontokhoz tartozó $(N, A, M) \in \mathcal{R}^{n}$ rangsorolási problémák? Ehhez kapcsolódóan, rögzített $G$ összehasonlítási multigráf mellett előállítható-e a fenti három eset mindegyike az $A$ eredménymátrix alkalmas megválasztásával? Az I. pont esetén biztosan, mert az $a_{i j}=0$ minden $X_{i}, X_{j} \in N$-re definícióval elérhető $\mathbf{s}=\mathbf{0}$.

A gyakorlati alkalmazás szempontjából az iterált értékelések oszcillációja nem tűnik jelentős problémának, mert a reguláris páros gráfok nagyon speciális összehasonlítási szerkezetet határoznak meg.Ekkor a 2.8. Megjegyzés szerint például nem létezhetnek páratlan hosszú körök, köztük olyan $\left(X_{i}, X_{j}, X_{k}\right)$ triádok, melyekben az összehasonlítás eredménye mindhárom $\left(X_{i}, X_{j}\right),\left(X_{i}, X_{k}\right)$ és $\left(X_{j}, X_{k}\right)$ párra ismert.

A 4.2. Tétel szükséges feltételei közül a $G$ összehasonlítási multigráf összefüggősége a legkisebb négyzetek módszerének egyértelmű megoldhatóságához (3.4. Állítás) hasonlóan értékelhető, ez az objektumok összehasonlíthatóságának minimális követelménye. A konvergencia hiánya a regularitás és párosság együttes következménye, ilyen gráfokra az optimális súlyok számítása ciklikus: az egyik csoport értékeléseinek meghatározásához szükség van a másikéira, és fordítva.

Ez gyengébb feltétel, mint a rekurzív teljesítményre (Brozos-Vázquez et al., 2008) vonatkozó, ami egyetlen páros gráfra sem (feltétlenül) müködik. A legkisebb négyzetek módszerének felbontásában nem reguláris $G$ esetén már megjelennek a hurokélek a $G^{\prime}$ kiegyensúlyozott összehasonlítási multigráfban, ami biztosítja a határérték létezését. A rendhagyó eset tisztán matematikai érveléssel állt elő. A bizonyos esetekben reguláris páros gráfokra is megfigyelt konvergenciát nem a 4.2. Lemma, hanem az $A$ eredménymátrix garantálja. 


\section{F.II. Függelék: Lineáris rendezések távolsága}

A 7.2.2. alfejezetben a rangsorok (lineáris rendezések) összehasonlítását távolságuk definiálásával hajtottuk végre. Az alábbiakban Can (2014) alapján indokoljuk ezek kiválasztását.

F.II.1. Definíció. Eltérésfüggvény (dissimilarity function) : Egy $\delta: \mathcal{L}^{n} \times \mathcal{L}^{n} \rightarrow \mathbb{R}$ függvény eltérésfüggvény, ha teljesíti az alábbi feltételeket:

- Nemnegativitás (non-negativity):

$\delta\left(L, L^{\prime}\right) \geq 0$ minden $L, L^{\prime} \in \mathcal{L}^{n}$-re;

- Megkülönböztethetetlenség (identity of indiscernibles):

$\delta\left(L, L^{\prime}\right)=0 \Leftrightarrow L=L^{\prime}$ minden $L, L^{\prime} \in \mathcal{L}^{n}$-re;

- Szimmetria (symmetry):

$\delta\left(L, L^{\prime}\right)=\delta\left(L^{\prime}, L\right)$ minden $L, L^{\prime} \in \mathcal{L}^{n}$-re.

F.II.2. Definíció. Távolságfüggvény (distance function, metric): Egy $\delta: \mathcal{L}^{n} \times$ $\times \mathcal{L}^{n} \rightarrow \mathbb{R}$ eltérésfüggvény távolságfüggvény, amennyiben teljesíti a háromszögegyenlőtlenséget (triangular inequality), vagyis $\delta\left(L, L^{\prime \prime}\right) \leq \delta\left(L, L^{\prime}\right)+\delta\left(L^{\prime}, L^{\prime \prime}\right)$ minden $L, L^{\prime}, L^{\prime \prime} \in \mathcal{L}^{n}$ esetén.

F.II.3. Definíció. Kemény-távolság (Kemeny distance) (Kemeny, 1959): Az $L, L^{\prime} \in$ $\in \mathcal{L}^{n}$ lineáris rendezések $\delta^{K}\left(L, L^{\prime}\right)$ Kemény-távolsága az egyiktől a másikhoz történő eljutás érdekében felcserélendő objektumpárok száma.

A fogalom különböző tudományterületen más-más elnevezéssel szerepel (Can és Storcken, 2013), általunk ismert legkorábbi megjelenése Cramer (1750). Közgazdászoknak talán ismerősebben cseng a Kendall $\tau$ távolság (Kendall, 1938).

Kemeny és Snell (1962) Kemény-távolságra adott karakterizációjáról Can és Storcken (2013) megmutatta, hogy a felhasznált öt axióma logikailag nem független, közülük négy is elegendő az egyértelmüséghez.

F.II.1. Állítás. $A \delta^{K}$ Kemény-távolság az egyetlen olyan $\delta: \mathcal{L}^{n} \times \mathcal{L}^{n} \rightarrow \mathbb{R}$ távolságfüggvény, ami teljesíti az alábbi feltételeket:

- Erős dekomponálhatóság (strong decomposability, betweenness): $\delta\left(L, L^{\prime \prime}\right)=\delta\left(L, L^{\prime}\right)+\delta\left(L^{\prime}, L^{\prime \prime}\right)$ minden $L, L^{\prime}, L^{\prime \prime} \in \mathcal{L}^{n}-r e$;

- Semlegesség (neutrality): tetszőleges $\sigma: N \rightarrow N$ permutációra $\delta\left(L, L^{\prime}\right)=\delta\left(\sigma L, \sigma L^{\prime}\right)$ minden $L, L^{\prime} \in \mathcal{L}^{n}$ mellett;

- Normalizálás (normalization): $\min _{L, L^{\prime} \in \mathcal{L}^{n}}\left\{\delta\left(L, L^{\prime}\right): L \neq L^{\prime}\right\}=1$. 
Bizonyítás. Lásd Can és Storcken (2013, Corollary 1). Az első tulajdonság a távolságfüggvény definíciója.

F.II.1. Megjegyzés. A normalizálás követelményének elhagyásával $\delta^{K}$ pozitív konstansszorosai is megengedetté válnak (Can és Storcken, 2013), ez azonban nem változtat a rangsorok távolságainak arányán.

A Kemény-távolság a távolság számításánál nem tesz különbséget a szükséges cserék helye szerint, például az $X_{i} \succ X_{j} \succ X_{k}$ rangsortól ugyanolyan messze (egy távolságra) található $X_{j} \succ X_{i} \succ X_{k}$, mint $X_{i} \succ X_{k} \succ X_{j}$. Mégis úgy érezzük, előbbi az utóbbinál jobban eltér az eredetitől, mert az első és második helyezett változása fontosabbnak tűnik, mint a második és harmadik felcserélődése. Egy sakkverseny végeredményénél jogos felvetés lehet, hogy a mezőny első felének rangsorolása, különösen a dobogón végző csapatok meghatározása élvezzen prioritást.

Ennek beépítéséhez nyilván le kell mondanunk az F.II.1. Állításban szereplő tulajdonságok valamelyikéről. Az F.II.1. Megjegyzés szerint a normalizálás mellőzése nem szünteti meg a fenti problémát, a szimmetria kihagyása pedig indokolhatatlan. Amennyiben továbbra is távolságokat keresünk, csak az erős dekomponálhatóság maradt, miszerint a végeredmény szempontjából teljesen mindegy, milyen sorrendben végezzük el a szükséges cseréket. Részben ez az axióma is megőrizhető lesz.

F.II.4. Definíció. Lineáris rendezésekből álló út (path on linear orders) : Legyen $L, L^{\prime} \in \mathcal{L}^{n}$ két lineáris rendezés. $L=L_{0}, L_{1}, L_{2}, \ldots, L_{k}=L^{\prime}$ egy $L$-ből $L^{\prime}$-be vezető lineáris rendezésekböl álló út, ha $\delta^{K}\left(L_{\ell}, L_{\ell+1}\right)=1$ minden $\ell=0,1, \ldots, k-1$ esetén.

Tehát a lineáris rendezésekből álló út szomszédos elemei között mindig csak egyetlen cserét kell elvégezni.

F.II.1. Jelölés. Legyen $L, L^{\prime} \in \mathcal{L}^{n}$ két lineáris rendezés. $\mathcal{W}\left(L, L^{\prime}\right)$ az $L$-ből $L^{\prime}$-be vezető, lineáris rendezésekből álló utak halmaza.

F.II.5. Definíció. Dekomponálhatóság (decomposability) (Can, 2014): Egy $\delta: \mathcal{L}^{n} \times$ $\times \mathcal{L}^{n} \rightarrow \mathbb{R}$ eltérésfüggvény dekomponálható, ha minden $L, L^{\prime} \in \mathcal{L}^{n}$-re létezik olyan $L$-ből $L^{\prime}$-be vezető $\left(L=L_{0}, L_{1}, L_{2}, \ldots, L_{k}=L^{\prime}\right) \in \mathcal{W}\left(L, L^{\prime}\right)$ lineáris rendezésekből álló út, amire

$$
\delta\left(L, L^{\prime}\right)=\sum_{\ell=1}^{k-1} \delta\left(L_{\ell}, L_{\ell+1}\right) .
$$

Erősen dekomponálható távolságfüggvény esetén bármelyik $L$-ből $L^{\prime}$-be vezető $\left(L=L_{0}, L_{1}, L_{2}, \ldots, L_{k}=L^{\prime}\right) \in \mathcal{W}\left(L, L^{\prime}\right)$ lineáris rendezésekből álló út választható.

A következő axióma a semlegességet módosítja annak az új koncepciónak megfelelően, hogy a lineáris rendezésekben előforduló eltérések fontossága az elfoglalt helyezés függvénye lehet. 
F.II.6. Definíció. Pozíciós semlegesség (positional neutrality) (Can, 2014): Legyen $k<n, k \in \mathbb{N}$, illetve $L, L^{\prime} \in \mathcal{L}^{n}$ és $\bar{L}, \bar{L}^{\prime} \in \mathcal{L}^{n}$ olyan lineáris rendezések, hogy $L$ és $L^{\prime}$, valamint $\bar{L}$ és $\bar{L}^{\prime}$ a $k$-adik és $k+1$-edik objektum felcserélésével kapható egymásból, azaz $\delta^{K}\left(L, L^{\prime}\right)=\delta^{K}\left(\bar{L}, \bar{L}^{\prime}\right)=1$. Egy $\delta: \mathcal{L}^{n} \times \mathcal{L}^{n} \rightarrow \mathbb{R}$ eltérésfüggvény pozíciós semleges, ha $\delta\left(L, L^{\prime}\right)=\delta\left(\bar{L}, \bar{L}^{\prime}\right)$.

A pozíciós semlegesség fennállásakor két szomszédos rangsor távolsága kizárólag attól függ, melyik pozícióban történt változás.

F.II.2. Jelölés. A $h: \mathcal{L}^{n} \times \mathcal{L}^{n} \rightarrow\{1,2, \ldots, n-1\}$ függvény megadja, hogy az $\bar{L}, \bar{L}^{\prime} \in$ $\in \mathcal{L}^{n}$ szomszédos lineáris rendezések $\left(\delta^{K}\left(\bar{L}, \bar{L}^{\prime}\right)=1\right)$ között melyik pozíció cserélődik fel. Az indexelés a kettő közül a kisebb számmal történik.

F.II.7. Definíció. Súlyozott eltérésfüggvény (weighted dissimilarity function) (Can, 2014): Legyen $L, L^{\prime} \in \mathcal{L}^{n}$ két lineáris rendezés. Egy $\delta_{\omega}: \mathcal{L}^{n} \times \mathcal{L}^{n} \rightarrow \mathbb{R}$ eltérésfüggvény súlyozott, ha létezik olyan $\omega \in \mathbb{R}^{n-1}$ súlyvektor, amire valamelyik $L$-ből $L^{\prime}$-be vezető $\left(L=L_{0}, L_{1}, L_{2}, \ldots, L_{k}=L^{\prime}\right) \in \mathcal{W}\left(L, L^{\prime}\right)$ lineáris rendezésekből álló út esetén

$$
\delta_{\omega}\left(L, L^{\prime}\right)=\sum_{\ell=1}^{k-1} \omega_{h\left(L_{\ell}, L_{\ell+1}\right)} .
$$

Az $\omega \in \mathbb{R}^{n-1}$ súlyvektor definiálja az egyes pozíciókban végrehajtott cserék fontosságát: $\omega_{1}$ az első és második, $\omega_{2}$ a második és harmadik, és így tovább, $\omega_{n-1}$ az utolsó előtti és az utolsó helyezett felcserélésének értékét. A távolságok relatív nagysága invariáns az $\omega$ súlyvektor pozitív konstanssal való szorzására.

F.II.2. Állítás. Egy $\delta: \mathcal{L}^{n} \times \mathcal{L}^{n} \rightarrow \mathbb{R}$ eltérésfüggvény akkor és csak akkor dekomponálható és pozíció semleges, ha $\delta=\delta_{\omega}$ súlyozott eltérésfüggvény.

Bizonyítás. Lásd Can (2014, Proposition 1).

F.II.3. Állítás. Egy $\delta: \mathcal{L}^{n} \times \mathcal{L}^{n} \rightarrow \mathbb{R}$ eltérésfüggvény akkor és csak akkor erösen dekomponálható és pozíció semleges, ha $\delta=\delta_{\omega}$ súlyozott eltérésfüggvény az $\omega=$ $=[c, c, \ldots, c]^{\top} \in \mathbb{R}^{n-1}, c>0$ súlyvektorral.

Bizonyítás. Lásd Can (2014, Proposition 2).

F.II.2. Megjegyzés. Az $\omega=[c, c, \ldots, c]^{\top} \in \mathbb{R}^{n-1}, c>0$ súlyvektorral adott súlyozott eltérésfüggvényre $\delta_{\omega}=c \delta^{K}$, így a Kemény-távolság az $\omega=$ e választással írható le.

Vagyis, ha szeretnénk különböző súlyokat adni az egyes pozíciókban bekövetkező változásoknak, az erős dekomponálhatóságot már nem lehet megkövetelni. A súlyozott eltérésfüggvény F.II.7. Definíciója megengedi, hogy az $\left(L=L_{0}, L_{1}, L_{2}, \ldots, L_{k}=\right.$ $\left.=L^{\prime}\right) \in \mathcal{W}\left(L, L^{\prime}\right)$ dekompozíció a vizsgált $L, L^{\prime} \in \mathcal{L}^{n}$ lineáris rendezésekre ex ante rögzített legyen, ami meglehetősen furcsának tűnik. Ezt küszöböli ki a következő függvénycsalád. 
F.II.8. Definíció. Útminimalizáló súlyozott eltérésfüggvény (path-minimizing function) (Can, 2014): Egy $\delta_{\omega}^{P M}: \mathcal{L}^{n} \times \mathcal{L}^{n} \rightarrow \mathbb{R}$ súlyozott eltérésfüggvény útminimalizáló, ha létezik olyan $\omega \in \mathbb{R}^{n-1}$ súlyvektor, amire minden $L, L^{\prime} \in \mathcal{L}^{n}$ esetén

$$
\delta_{\omega}^{P M}\left(L, L^{\prime}\right)=\min _{\left(L=L_{0}, L_{1}, L_{2}, \ldots, L_{k}=L^{\prime}\right) \in \mathcal{W}\left(L, L^{\prime}\right)} \sum_{\ell=1}^{k-1} \omega_{h\left(L_{\ell}, L_{\ell+1}\right)} .
$$

Az útminimalizálás lehetővé teszi a távolságfüggvényekre való áttérést.

F.II.4. Állítás. Legyen $\omega \in \mathbb{R}^{n-1}$ egy rögzített súlyvektor. $A \quad \delta_{\omega}: \mathcal{L}^{n} \times \mathcal{L}^{n} \rightarrow$ $\mathbb{R}$ eltérésfüggvény akkor és csak akkor teljesíti a háromszög-egyenlötlenséget (azaz távolságfüggvény), ha $\delta_{\omega}=\delta_{\omega}^{P M}$ útminimalizáló súlyozott eltérésfüggvény.

Bizonyítás. Lásd Can (2014, Theorem 1). A bizonyítás kulcsa, hogy $\delta_{\omega}$-nak minden előre rögzített $\omega \in \mathbb{R}^{n-1}$ súlyvektor mellett távolságfüggvénynek kell lennie.

Az erős dekomponálhatóság hiánya továbbra is gondot okozhat, mert a végeredményben számítani fog a cserék végrehajtásának sorrendje. Az útminimalizáló lineáris rendezésekből álló út meghatározása bonyolult lehet, a Dijkstra-algoritmushoz hasonló módszerrel, vagy nyers erővel, a két rangsor közötti összes lehetséges út közül a minimális kiválasztásával kapható (Can, 2014). Bizonyos esetekben azonban az útminimalizáló dekompozíció explicit formában is megadható.

F.II.9. Definíció. Lehmer-függvény (Lehmer function) (Can, 2014): Egy $\delta_{\omega}^{L}: \mathcal{L}^{n} \times$ $\times \mathcal{L}^{n} \rightarrow \mathbb{R}$ súlyozott eltérésfüggvény Lehmer-függvény, ha minden $\omega \in \mathbb{R}^{n-1}$ súlyvektor és $L, L^{\prime} \in \mathcal{L}^{n}$ lineáris rendezés esetén

$$
\delta_{\omega}^{L}\left(L, L^{\prime}\right)=\min _{\left(L=L_{0}, L_{1}, L_{2}, \ldots, L_{k}=L^{\prime}\right) \in \mathcal{W}\left(L, L^{\prime}\right)} \sum_{\ell=1}^{k-1} \omega_{h\left(L_{\ell}, L_{\ell+1}\right)}=\sum_{\ell=1}^{k-1} \omega_{h\left(L_{\ell}^{w}, L_{\ell+1}^{w}\right)}
$$

ahol $\left(L=L_{0}^{w}, L_{1}^{w}, L_{2}^{w}, \ldots, L_{k}^{w}=L^{\prime}\right) \in \mathcal{W}\left(L, L^{\prime}\right)$ az az $L$-ből $L^{\prime}$-be vezető lineáris rendezésekből álló út, amely először az $L^{\prime}$-ben győztes objektumot viszi ebbe a pozícióba, majd az $L^{\prime}$-ben második objektum kerül a második helyre, és így tovább. ${ }^{38}$

A Lehmer-függvényben a két lineáris rendezés között alkalmazandó dekompozíció a fenti algoritmus által adott. Ezt illusztrálja az alábbi példa.

F.II.1. Példa. Legyen $L=\left\{X_{1}, X_{2}, X_{3}, X_{4}\right\}, L^{\prime}=\left\{X_{3}, X_{1}, X_{4}, X_{2}\right\}$, és $\omega=$ $=[3,2,1]$. Ekkor az F.II.9. Definícióban szereplő, $L$-ből $L^{\prime}$-be vezető lineáris rendezésekből álló út elemei:

38 Remélhetőleg nem okoz félreértést a $\delta_{\omega}^{L}$ jelölés, ebben $L$ nyilván nem egy lineáris rendezés. 


$$
\begin{aligned}
L_{0}^{w} & =\left\{X_{1}, X_{2}, X_{3}, X_{4}\right\}=L \\
L_{1}^{w} & =\left\{X_{1}, X_{3}, X_{2}, X_{4}\right\} \\
L_{2}^{w} & =\left\{X_{3}, X_{1}, X_{2}, X_{4}\right\} \\
L_{3}^{w} & =\left\{X_{3}, X_{1}, X_{4}, X_{3}\right\}=L^{\prime} .
\end{aligned}
$$

Tehát sorozatos elemi cserékkel először $X_{3}$-at visszük az első pozícióba, majd mivel $X_{1}$ már a helyén van - $X_{4}$-et a harmadikba. Ennek megfelelöen $\delta_{\omega}^{L}\left(L, L^{\prime}\right)=$ $=\delta_{\omega}^{L}\left(L_{0}^{w}, L_{1}^{w}\right)+\delta_{\omega}^{L}\left(L_{1}^{w}, L_{2}^{w}\right)+\delta_{\omega}^{L}\left(L_{2}^{w}, L_{3}^{w}\right)=\omega_{2}+\omega_{1}+\omega_{3}=6$.

A Kemény-távolság az $\bar{\omega}=[1,1,1]$ súlyvektorral kapható tetszőleges $L$-ből $L^{\prime}$-be vezető lineáris rendezésekből álló út mentén, ezért $\delta^{K}\left(L, L^{\prime}\right)=\delta_{\bar{\omega}}^{L}\left(L, L^{\prime}\right)=\bar{\omega}_{2}+\bar{\omega}_{1}+$ $+\bar{\omega}_{3}=3$.

F.II.5. Állítás. $\delta_{\omega}^{P M}\left(L, L^{\prime}\right)=\delta_{\omega}^{L}\left(L, L^{\prime}\right)$ minden $L, L^{\prime} \in \mathcal{L}^{n}$ esetén akkor és csak akkor, ha $\omega$ monoton csökkenö, $\omega_{k}<\omega_{k+1}$ minden $k=1,2, \ldots n-2$-re.

Bizonyítás. Lásd Can (2012, Proposition 3).

Az F.II.5. Állítás értelmében a Lehmer-függvény akkor és csak akkor útminimalizáló súlyozott eltérésfüggvény, ha az $\omega$ súlyvektor monoton csökkenő. Egy sakkverseny esetén ez elfogadható megszorításnak tünik, mert az egyes pozíciókban megfigyelt eltérések fontossága fokozatosan kisebb lehet. Más esetekben nem feltétlenül ez a helyzet. Amennyiben például egy 20 csapatos labdarúgó-bajnokság utolsó két helyezettje esik ki (kerül alsóbb osztályba), a 18. helyezés nagyobb jelentőségüvé válhat, mint a 13 . vagy a 16.

F.II.1. Következmény. Legyen $\omega \in \mathbb{R}^{n-1}$ egy rögzített súlyvektor. Egy $\delta_{\omega}^{L}: \mathcal{L}^{n} \times$ $\times \mathcal{L}^{n} \rightarrow \mathbb{R}$ Lehmer-függvény akkor és csak akkor távolságfüggvény (azaz teljesíti a háromszög-egyenlötlenséget), ha $\omega$ monoton csökkenö, $\omega_{k}<\omega_{k+1}$ minden $k=$ $=1,2, \ldots, n-2$-re.

Bizonyítás. Lásd Can (2012, Corollary 1). Az F.II.4. és az F.II.5. Állításból adódik.

A további részletek iránt érdeklődő olvasó figyelmébe ajánljuk Can (2014) tanulmányát.

Can (2014) fenti eredményei alapján egy ilyen (szigorúan) monoton csökkenő súlyvektort választottunk.

F.II.10. Definíció. Súlyozott távolság (weighted distance): A $\delta_{1 / k}^{L}: \mathcal{L}^{n} \times \mathcal{L}^{n} \rightarrow \mathbb{R}$ Lehmer-függvény súlyozott távolság, ha $\omega \in \mathbb{R}^{n-1}$ súlyvektorára $\omega_{k}=1 / k$ minden $k=1,2, \ldots, n-1$ mellett. 
Ekkor például az első és második helyezett felcserélődése kétszer olyan fontos, mint a másodiké és a harmadiké. A választás egyik előnye a könnyen kiszámítható maximum, ugyanis két teljesen ellentétes rangsor súlyozott távolsága

$$
\begin{aligned}
\left(\frac{1}{n-1}+\frac{1}{n-2}+\cdots+1\right)+\left(\frac{1}{n-1}+\cdots+\frac{1}{2}\right)+\cdots+\frac{1}{n-1} & = \\
=\frac{n-1}{n-1}+\frac{n-2}{n-2}+\cdots+1 & =n-1 .
\end{aligned}
$$

Tudomásunk szerint ez a Can-féle súlyozott távolságfüggvény első gyakorlati alkalmazása, ezért nem áll rendelkezésünkre olyan ismeret, ami alátámaszthatná vagy támadhatóvá tenné a fenti meghatározást.

F.II.3. Megjegyzés. Can (2014) eredményének publikálása előtt magunk is kísérletet tettünk a rangsor elején előforduló eltéréseknek nagyobb súlyt adó távolságfüggvény konstruálására a $\tau$ távolság bevezetésével (Csató, 2013a). Ennek azonban hiányzik az axiomatikus megalapozása, nem dekomponálható, néhány esetben pedig indokolatlannak tünő fontosságot tulajdonít az első pozíciókban bekövetkező változásoknak. Ezen problémákat Csató (2013a) értelemszerüen kevésbé hangsúlyozta. Ezúton is szeretnénk köszönetet mondani Burak Cannak a súlyozott távolságfüggvény korrekt megalapozásáért. 
F.III. Függelék: Sakkcsapat EB-k eredményei és rangsorai 
F.1. táblázat. A 2011-es sakkcsapat Európa-bajnokság eredményei

\begin{tabular}{|c|c|c|c|c|c|c|c|c|c|c|c|c|c|c|c|c|c|c|c|}
\hline & $\begin{array}{l}\stackrel{\pi}{60} \\
\underset{Z}{4}\end{array}$ & 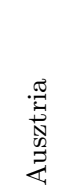 & 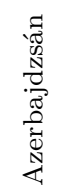 & 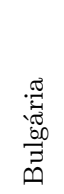 & 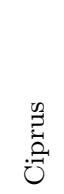 & $\begin{array}{l}60 \\
\mathbb{8} \\
0 \\
0 \\
0 \\
0 \\
0 \\
0 \\
0 \\
0\end{array}$ & $\stackrel{. \varpi}{\Xi}$ & 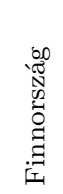 & 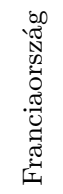 & 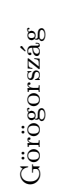 & 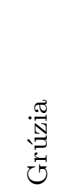 & 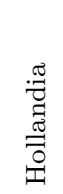 & 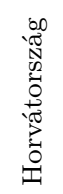 & $\begin{array}{l}\overrightarrow{\widetilde{Z}} \\
\frac{\mathbb{J}}{\mathbb{N}}\end{array}$ & $\begin{array}{l}\overrightarrow{\mathbb{J}} \\
\widetilde{\mathbb{N}}\end{array}$ & 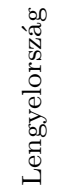 & 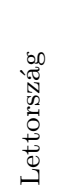 & 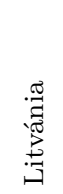 & 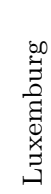 \\
\hline Anglia & - & - & - & - & - & 2 & - & 3,5 & - & 1,5 & - & - & - & - & 1,5 & 1 & 2,5 & 3 & - \\
\hline Ausztria & - & - & - & - & - & - & 2 & 2,5 & - & - & 2 & - & - & - & - & 1 & 1 & - & - \\
\hline Azerbajdzsán & - & - & - & 3,5 & - & - & - & - & 2 & 3 & - & - & - & - & - & - & - & - & - \\
\hline Bulgária & - & - & 0,5 & - & - & - & - & - & 2 & - & - & - & - & - & - & 2,5 & - & - & - \\
\hline Ciprus & - & - & - & - & - & - & 0 & 0 & - & 0 & 0 & - & - & - & - & - & - & - & 1,5 \\
\hline Csehország & 2 & - & - & - & - & - & - & - & - & - & - & 1,5 & - & - & 2,5 & - & 2 & - & - \\
\hline Dánia & - & 2 & - & - & 4 & - & - & - & - & - & - & - & - & - & 0,5 & - & 2,5 & - & - \\
\hline Finnország & 0,5 & 1,5 & - & - & 4 & - & - & - & - & - & - & 2 & - & - & - & 0 & - & - & 3,5 \\
\hline Franciaország & - & - & 2 & 2 & - & - & - & - & - & - & - & - & - & - & 2,5 & - & - & 3,5 & - \\
\hline Görögország & 2,5 & - & 1 & - & 4 & - & - & - & - & - & 2,5 & 1,5 & - & - & - & 2 & - & - & - \\
\hline Grúzia & - & 2 & - & - & 4 & - & - & - & - & 1,5 & - & - & 2 & 3 & - & - & - & - & - \\
\hline Hollandia & - & - & - & - & - & 2,5 & - & 2 & - & 2,5 & - & - & - & - & - & 2,5 & - & - & - \\
\hline Horvátország & - & - & - & - & - & - & - & - & - & - & 2 & - & - & - & - & 1 & - & - & - \\
\hline Izland & - & - & - & - & - & - & - & - & - & - & 1 & - & - & - & - & - & - & - & 3 \\
\hline Izrael & 2,5 & - & - & - & - & 1,5 & 3,5 & - & 1,5 & - & - & - & - & - & - & - & - & - & - \\
\hline Lengyelország & 3 & 3 & - & 1,5 & - & - & - & 4 & - & 2 & - & 1,5 & 3 & - & - & - & - & 2 & - \\
\hline Lettország & 1,5 & 3 & - & - & - & 2 & 1,5 & - & - & - & - & - & - & - & - & - & - & 2 & - \\
\hline Litvánia & 1 & - & - & - & - & - & - & - & 0,5 & - & - & - & - & - & - & 2 & 2 & - & - \\
\hline Luxemburg & - & - & - & - & 2,5 & - & - & 0,5 & - & - & - & - & - & 1 & - & - & - & - & - \\
\hline Macedónia & - & - & - & - & 4 & - & - & - & - & - & - & - & - & 1,5 & 1 & - & 1 & - & 2 \\
\hline Magyarország & - & - & - & 4 & - & 2 & 3 & - & - & - & - & - & 2 & - & - & - & 2,5 & - & - \\
\hline Moldova & - & 2,5 & - & - & - & 2 & 3 & - & 1,5 & - & - & - & 1,5 & - & - & - & - & - & 4 \\
\hline Montenegró & - & 2 & - & - & - & - & - & - & - & - & - & - & - & 1,5 & - & - & - & - & 3,5 \\
\hline Németország & - & - & 2,5 & 1 & - & - & - & - & - & - & - & - & - & - & 2 & - & - & - & - \\
\hline Norvégia & - & - & - & - & - & 0,5 & 0,5 & 3 & - & - & - & - & - & - & - & - & 1,5 & 2 & - \\
\hline Olaszország & - & - & 1,5 & 1 & - & - & - & - & - & 2,5 & - & - & - & - & 2,5 & - & - & - & - \\
\hline Oroszország & - & - & 1,5 & 1 & - & 3,5 & - & - & 2,5 & - & - & 2 & - & - & - & - & - & - & - \\
\hline Örményország & 2 & 3,5 & 1 & - & - & - & 3,5 & - & 2,5 & - & - & 3 & 3 & - & - & - & - & - & - \\
\hline Románia & - & - & 1 & - & - & - & - & - & - & 2,5 & - & 2,5 & - & - & - & - & - & 2,5 & - \\
\hline Skócia & - & - & - & - & 3 & - & 2 & 1 & - & - & 0,5 & - & 1 & 0 & - & - & - & 1 & - \\
\hline Spanyolország & - & - & 2 & - & - & - & - & - & 2,5 & 1,5 & - & - & - & 2,5 & - & - & 3 & - & - \\
\hline Svájc & - & - & - & 1,5 & - & - & - & - & - & - & - & - & 2 & - & 1,5 & - & - & 1 & - \\
\hline Svédország & - & - & - & - & - & - & - & 2,5 & 2 & - & 1 & 1,5 & 1,5 & - & - & - & - & - & 3 \\
\hline Szerbia & - & - & - & - & - & 1,5 & - & - & - & - & - & 1,5 & - & 2,5 & - & - & - & 3 & 4 \\
\hline Szlovénia & - & - & - & - & - & - & - & - & - & - & 2,5 & - & - & 3 & - & 2 & - & - & - \\
\hline Törökország & - & - & - & - & 3 & - & - & - & - & - & 2,5 & - & - & - & - & - & - & - & - \\
\hline Ukrajna & 2,5 & - & - & 2 & - & - & - & - & - & - & - & - & 3 & 3 & 2 & - & - & - & - \\
\hline Wales & - & 0 & - & - & 2 & - & - & - & - & - & - & - & - & - & - & - & - & - & 2 \\
\hline
\end{tabular}


F.1. táblázat. A 2011-es sakkcsapat Európa-bajnokság eredményei (folytatás)

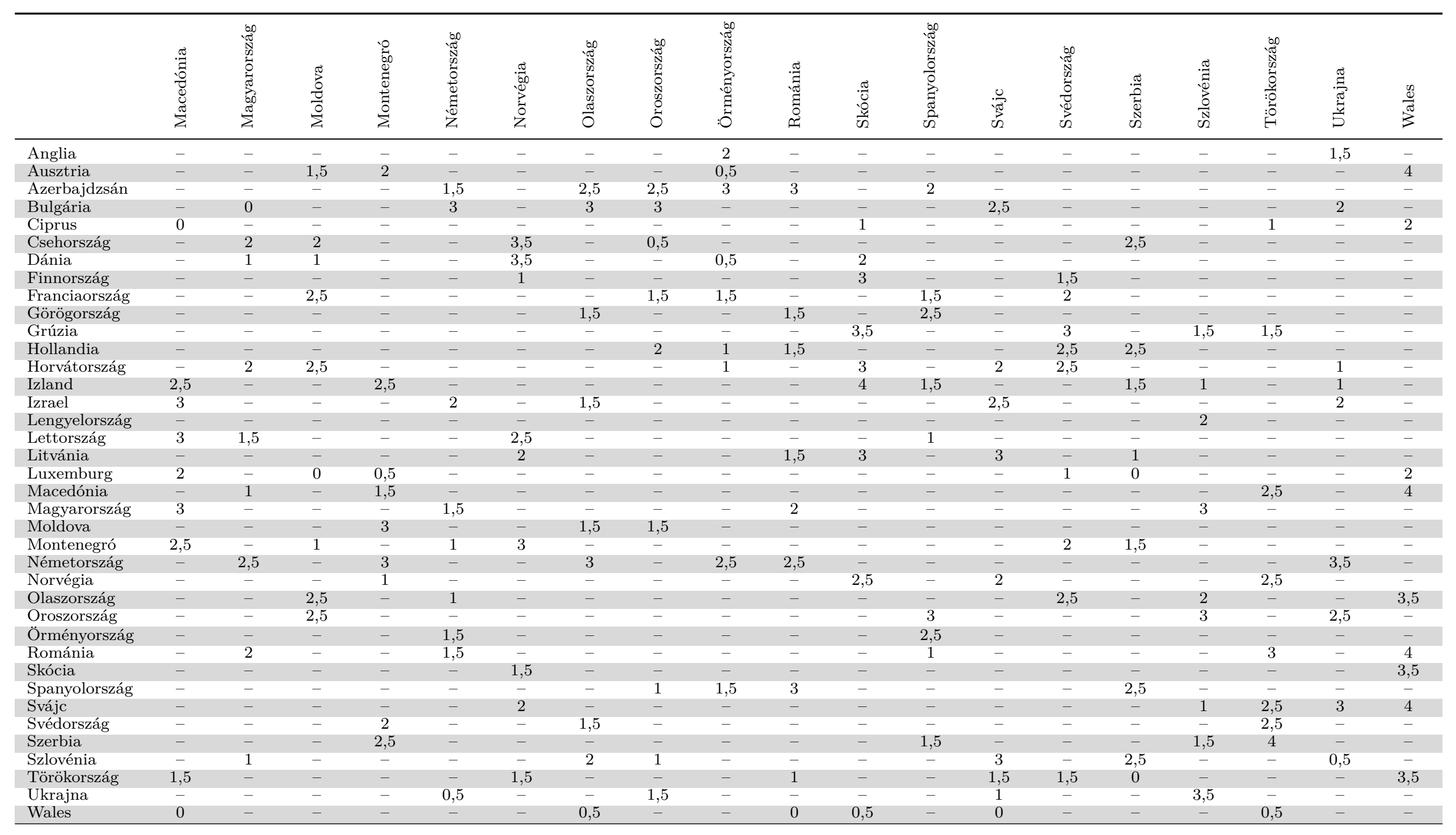

Anglia

Ausztria

Bulgária

sehorsz

Franciaország

örögország

Hollandi

larael

Lengyelorszá

Lettorszá

Luxemburg

Magyarország

Moldova

Németország

Norvégia

Románia

panyolorszá

vájc

zerbia

Törökor

Ukrajna

0,5

0,5 
F.2. táblázat. A 2013-as sakkcsapat Európa-bajnokság eredményei

\begin{tabular}{|c|c|c|c|c|c|c|c|c|c|c|c|c|c|c|c|c|c|c|c|}
\hline & $\begin{array}{l}\frac{\pi}{30} \\
\underset{8}{4}\end{array}$ & 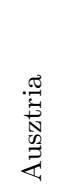 & 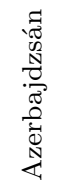 & 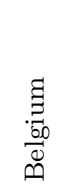 & 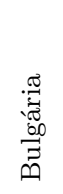 & 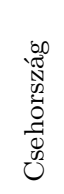 & 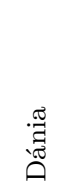 & 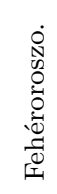 & 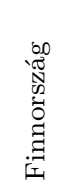 & 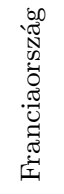 & 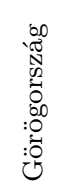 & 胥 & 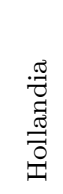 & 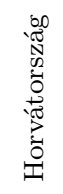 & $\begin{array}{l}\overrightarrow{\widetilde{Z}} \\
\stackrel{\widetilde{J}}{\mathbb{N}}\end{array}$ & $\begin{array}{l}\widetilde{\mathbb{W}} \\
\mathbb{N} \\
\end{array}$ & 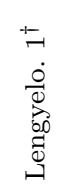 & 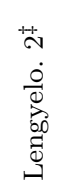 & 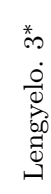 \\
\hline Anglia & - & - & - & - & - & - & - & - & - & - & 1 & 2 & - & - & - & - & 2 & - & 3 \\
\hline Ausztria & - & - & - & - & 1 & - & - & - & 2,5 & - & - & - & 2,5 & - & - & 0,5 & - & - & 2 \\
\hline Azerbajdzsán & - & - & - & - & 2,5 & 2,5 & - & - & - & 2 & 2,5 & 3 & - & - & - & - & 2,5 & - & - \\
\hline Belgium & - & - & - & - & - & - & 1,5 & - & - & - & - & 1,5 & - & - & 1,5 & - & - & - & - \\
\hline Bulgária & - & 3 & 1,5 & - & - & - & - & - & 3,5 & - & - & - & 0,5 & - & 2,5 & - & - & - & - \\
\hline Csehország & - & - & 1,5 & - & - & - & - & 2 & - & 1,5 & - & 2 & 2 & - & 2,5 & - & - & - & - \\
\hline Dánia & - & - & - & 2,5 & - & - & - & 1 & 2 & - & - & - & 1 & - & 1,5 & - & - & - & - \\
\hline Fehéroroszország & - & - & - & - & - & 2 & 3 & - & - & 1,5 & 1 & - & - & - & - & - & - & - & - \\
\hline Finnország & - & 1,5 & - & - & 0,5 & - & 2 & - & - & - & - & - & - & - & 2 & - & - & - & - \\
\hline Franciaország & - & - & 2 & - & - & 2,5 & - & 2,5 & - & - & 2,5 & - & - & - & - & - & - & - & - \\
\hline Görögország & 3 & - & 1,5 & - & - & - & - & 3 & - & 1,5 & - & 2 & - & 3 & - & - & - & - & - \\
\hline Grúzia & 2 & - & 1 & 2,5 & - & 2 & - & - & - & - & 2 & - & - & - & - & 3,5 & - & - & - \\
\hline Hollandia & - & 1,5 & - & - & 3,5 & 2 & 3 & - & - & - & - & - & - & - & - & 1,5 & - & - & 3 \\
\hline Horvátország & - & - & - & - & - & - & - & - & - & - & 1 & - & - & - & - & 2 & 2 & 3 & - \\
\hline Izland & - & - & - & 2,5 & 1,5 & 1,5 & 2,5 & - & 2 & - & - & - & - & - & - & - & 1 & - & 1,5 \\
\hline Izrael & - & 3,5 & - & - & - & - & - & - & - & - & - & 0,5 & 2,5 & 2 & - & - & - & 1,5 & - \\
\hline Lengyelország $1^{\dagger}$ & 2 & - & 1,5 & - & - & - & - & - & - & - & - & - & - & 2 & 3 & - & - & - & - \\
\hline Lengyelország $2^{\ddagger}$ & - & - & - & - & - & - & - & - & - & - & - & - & - & 1 & - & 2,5 & - & - & 3 \\
\hline Lengyelország $3^{*}$ & 1 & 2 & - & - & - & - & - & - & - & - & - & - & 1 & - & 2,5 & - & - & 1 & - \\
\hline Litvánia & - & - & - & 3 & - & - & 2 & - & 2,5 & - & 1,5 & - & - & - & - & - & - & 1 & 1,5 \\
\hline Macedónia & - & - & - & 1 & - & - & - & - & 1,5 & - & - & - & - & 1,5 & - & - & - & 0,5 & - \\
\hline Magyarország & 2 & - & 2 & - & - & - & 3 & 3 & - & 2 & - & 2 & - & - & - & - & - & - & - \\
\hline Montenegró & 0,5 & - & - & - & - & - & - & - & 2,5 & - & - & - & - & - & - & - & - & - & 2,5 \\
\hline Németország & 1,5 & - & - & - & - & - & - & - & - & - & - & 1,5 & - & - & - & 2,5 & 2 & 2 & - \\
\hline Norvégia & - & - & - & 0,5 & - & - & 0 & 1 & - & - & - & - & - & - & - & - & - & - & - \\
\hline Olaszország & - & - & - & - & 2,5 & 1 & - & - & 3 & - & 2 & - & - & - & - & 3,5 & - & - & - \\
\hline Oroszország & 2 & 4 & - & - & - & - & - & - & - & 2,5 & - & - & 2,5 & - & - & - & - & - & - \\
\hline Örményország & - & 2,5 & 2 & - & 2 & - & - & - & - & 2 & - & - & - & - & - & - & - & - & - \\
\hline Románia & - & 2 & - & - & - & 1,5 & - & - & - & - & 2 & - & - & 2 & - & - & - & - & 3 \\
\hline Skócia & - & - & - & 2 & - & - & - & - & - & - & - & - & - & - & 0,5 & - & - & - & - \\
\hline Spanyolország & - & 2 & - & - & - & - & - & - & - & - & - & - & - & 1,5 & 2,5 & - & 1,5 & 3 & - \\
\hline Svájc & - & - & - & - & 2,5 & - & - & - & - & - & - & - & - & - & - & 1 & 1 & - & - \\
\hline Svédország & - & - & 2 & - & 2 & - & - & - & - & - & - & - & - & - & - & - & - & 3 & - \\
\hline Szerbia & - & - & - & 3,5 & - & - & - & 1,5 & - & - & - & - & - & 2 & - & - & - & - & - \\
\hline Szlovénia & - & - & - & - & - & - & - & - & - & 1,5 & - & - & 0,5 & - & - & 2,5 & 2,5 & - & - \\
\hline Törökország & - & - & - & - & - & 0,5 & - & 1,5 & - & - & - & - & - & - & - & - & 2 & - & - \\
\hline Ukrajna & 2 & - & - & - & - & - & - & 2 & - & 1 & - & 1,5 & - & 2,5 & - & - & - & 3 & - \\
\hline Wales & - & - & - & 0 & - & - & 0,5 & - & 0 & - & - & - & 0 & - & - & - & - & - & 0,5 \\
\hline
\end{tabular}

${ }^{\dagger}$ Poland $\quad{ }^{\ddagger}$ Poland Futures $\quad{ }^{*}$ Poland Goldies 
F.2. táblázat. A 2013-as sakkcsapat Európa-bajnokság eredményei (folytatás)

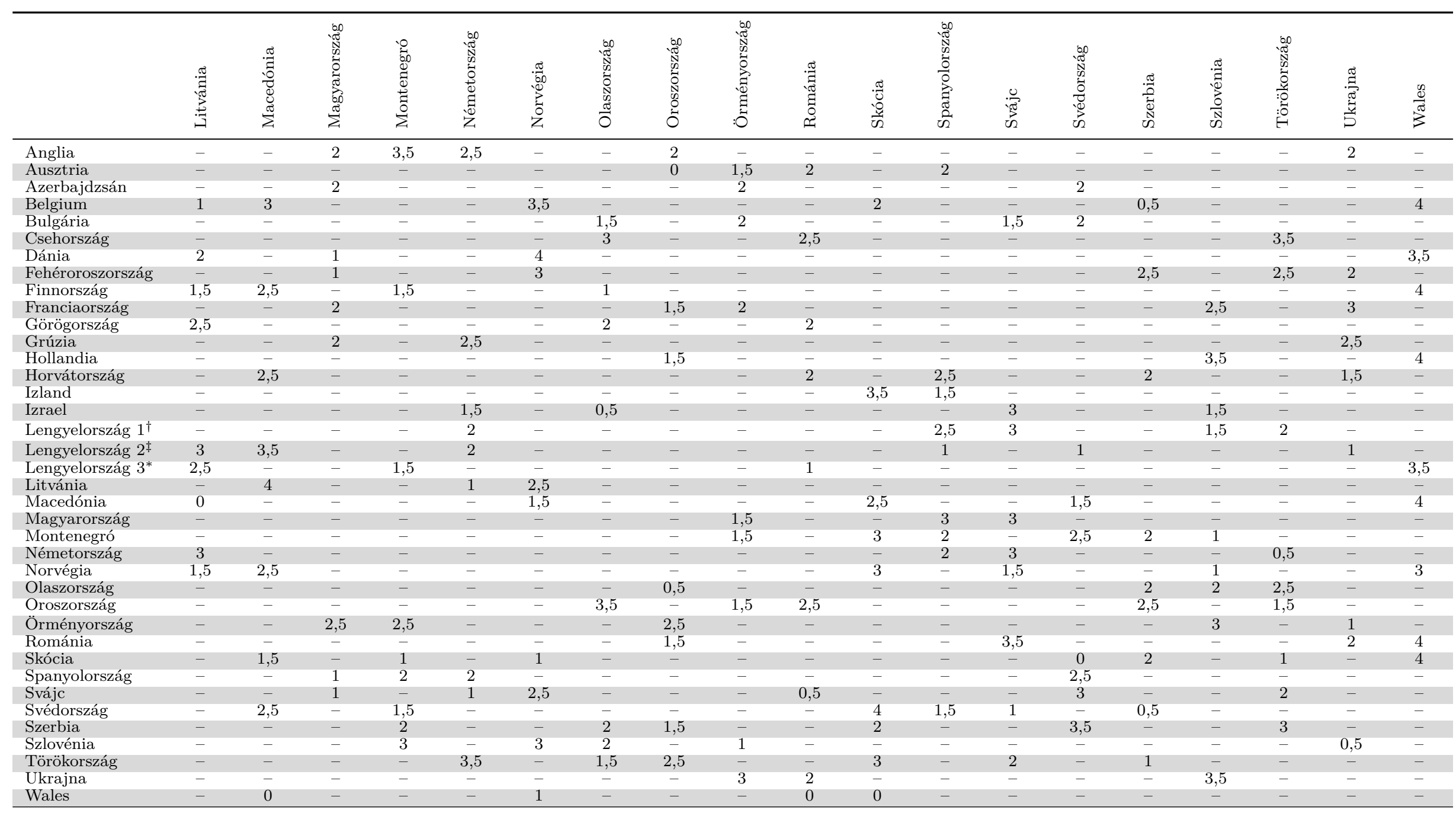

Anglia

Ausztria

Azerbajdzsán

Bulgária

D́́niszá

ehérorosz

Görögorszá

Horvátorsz

zrael

engyelország

Lengyelország

itvánia

Magyarorsz

Montenegró

orvégia

Orményország

panyolország

svédorsz

zerbia

Törökorszá

${ }^{\ddagger}$ Poland Future

${ }^{*}$ Poland Goldies 
F.3. táblázat. A 2011-es sakkcsapat Európa-bajnokság rangsorai

\begin{tabular}{|c|c|c|c|c|c|c|c|c|c|c|c|c|c|c|}
\hline Csapat & $\begin{array}{l}\text { 莧 } \\
\text { in }\end{array}$ & 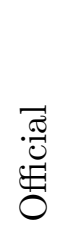 & 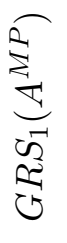 & 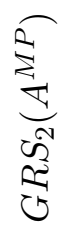 & 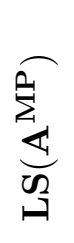 & 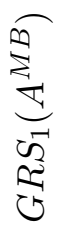 & 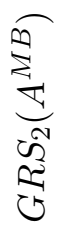 & 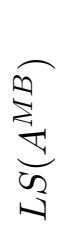 & 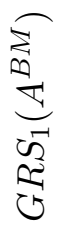 & 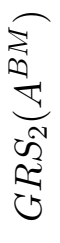 & 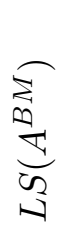 & 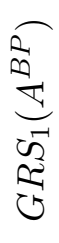 & 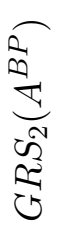 & $\frac{\overparen{a}}{\sqrt{0}}$ \\
\hline Anglia & 8 & 22 & 22 & 21 & 19 & 22 & 22 & 18 & 21 & 21 & 18 & 20 & 20 & 17 \\
\hline Ausztria & 23 & 32 & 31 & 31 & 30 & 32 & 31 & 30 & 31 & 30 & 30 & 31 & 30 & 30 \\
\hline Azerbajdzsán & 3 & 2 & 2 & 2 & 1 & 2 & 2 & 1 & 2 & 2 & 1 & 1 & 1 & 1 \\
\hline Bulgária & 7 & 7 & 6 & 5 & 4 & 7 & 6 & 4 & 11 & 6 & 5 & 18 & 9 & 6 \\
\hline Ciprus & 38 & 38 & 38 & 38 & 38 & 38 & 38 & 38 & 38 & 38 & 38 & 37 & 38 & 38 \\
\hline Csehország & 12 & 16 & 14 & 14 & 14 & 16 & 14 & 16 & 17 & 16 & 15 & 19 & 17 & 14 \\
\hline Dánia & 24 & 28 & 28 & 27 & 26 & 28 & 28 & 27 & 29 & 28 & 29 & 29 & 28 & 29 \\
\hline Finnország & 28 & 31 & 32 & 32 & 32 & 31 & 32 & 32 & 30 & 33 & 32 & 30 & 32 & 33 \\
\hline Franciaország & 6 & 19 & 18 & 15 & 10 & 19 & 15 & 9 & 18 & 13 & 8 & 14 & 11 & 8 \\
\hline Görögország & 19 & 20 & 19 & 17 & 17 & 20 & 18 & 17 & 19 & 18 & 17 & 16 & 18 & 18 \\
\hline Grúzia & 15 & 13 & 17 & 22 & 27 & 13 & 21 & 25 & 8 & 20 & 24 & 7 & 16 & 23 \\
\hline Hollandia & 9 & 6 & 7 & 7 & 8 & 6 & 7 & 8 & 9 & 9 & 9 & 13 & 13 & 12 \\
\hline Horvátország & 16 & 21 & 20 & 19 & 18 & 21 & 20 & 19 & 23 & 22 & 21 & 28 & 23 & 21 \\
\hline Izland & 32 & 26 & 26 & 28 & 28 & 26 & 27 & 28 & 26 & 26 & 26 & 25 & 25 & 26 \\
\hline Izrael & 11 & 14 & 15 & 16 & 15 & 14 & 16 & 15 & 13 & 14 & 14 & 10 & 10 & 11 \\
\hline Lengyelország & 14 & 8 & 11 & 12 & 16 & 8 & 11 & 13 & 6 & 8 & 12 & 5 & 6 & 9 \\
\hline Lettország & 27 & 24 & 23 & 23 & 22 & 24 & 23 & 22 & 24 & 23 & 22 & 23 & 22 & 22 \\
\hline Litvánia & 33 & 33 & 30 & 29 & 24 & 33 & 29 & 24 & 33 & 29 & 25 & 32 & 29 & 25 \\
\hline Luxemburg & 37 & 36 & 36 & 36 & 36 & 36 & 36 & 36 & 36 & 36 & 36 & 36 & 36 & 36 \\
\hline Macedónia & 30 & 30 & 33 & 33 & 33 & 30 & 33 & 33 & 28 & 31 & 33 & 22 & 31 & 31 \\
\hline Magyarorsz & 5 & 3 & 5 & 6 & 6 & 3 & 5 & 6 & 3 & 5 & 6 & 2 & 4 & 5 \\
\hline Mold & 20 & 18 & 21 & 20 & 20 & 18 & 19 & 20 & 15 & 19 & 20 & 9 & 14 & 20 \\
\hline Montenegró & 29 & 25 & 25 & 26 & 29 & 25 & 26 & 29 & 25 & 25 & 28 & 24 & 24 & 27 \\
\hline Németország & 10 & 1 & 1 & 1 & 2 & 1 & 1 & 2 & 1 & 1 & 2 & 3 & 2 & 2 \\
\hline Norvégia & 31 & 29 & 29 & 30 & 31 & 29 & 30 & 31 & 32 & 32 & 31 & 34 & 33 & 32 \\
\hline Olaszorszć & 22 & 11 & 9 & 9 & 9 & 11 & 10 & 10 & 14 & 12 & 11 & 17 & 19 & 15 \\
\hline Oroszország & 1 & 5 & 3 & 3 & 3 & 5 & 3 & 3 & 5 & 4 & 3 & 8 & 5 & 3 \\
\hline Örményország & 4 & 4 & 4 & 4 & 5 & 4 & 4 & 5 & 4 & 3 & 4 & 4 & 3 & 4 \\
\hline Románia & 17 & 9 & 10 & 10 & 12 & 9 & 9 & 12 & 10 & 10 & 13 & 11 & 12 & 13 \\
\hline Skócia & 35 & 35 & 35 & 35 & 35 & 35 & 35 & 35 & 35 & 35 & 35 & 35 & 35 & 35 \\
\hline Spanyolország & 13 & 10 & 8 & 8 & 7 & 10 & 8 & 7 & 12 & 7 & 7 & 12 & 8 & 7 \\
\hline Svájc & 26 & 23 & 27 & 24 & 23 & 23 & 24 & 23 & 22 & 24 & 23 & 21 & 26 & 24 \\
\hline Svédország & 25 & 27 & 24 & 25 & 25 & 27 & 25 & 26 & 27 & 27 & 27 & 27 & 27 & 28 \\
\hline Szerbia & 18 & 12 & 16 & 18 & 21 & 12 & 17 & 21 & 7 & 15 & 19 & 6 & 7 & 16 \\
\hline Szlovénia & 21 & 17 & 12 & 13 & 13 & 17 & 13 & 14 & 20 & 17 & 16 & 26 & 21 & 19 \\
\hline Törökország & 34 & 34 & 34 & 34 & 34 & 34 & 34 & 34 & 34 & 34 & 34 & 33 & 34 & 34 \\
\hline Ukrajna & 2 & 15 & 13 & 11 & 11 & 15 & 12 & 11 & 16 & 11 & 10 & 15 & 15 & 10 \\
\hline Wales & 36 & 37 & 37 & 37 & 37 & 37 & 37 & 37 & 37 & 37 & 37 & 38 & 37 & 37 \\
\hline
\end{tabular}


F.4. táblázat. A 2013-as sakkcsapat Európa-bajnokság rangsorai

\begin{tabular}{|c|c|c|c|c|c|c|c|c|c|c|c|c|c|c|}
\hline Csapat & 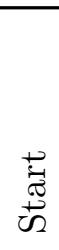 & 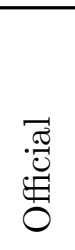 & 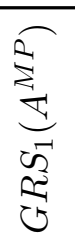 & 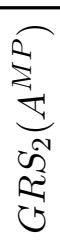 & 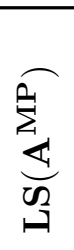 & 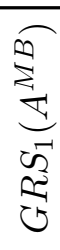 & 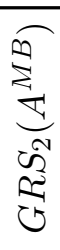 & 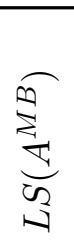 & 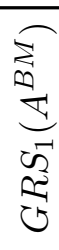 & 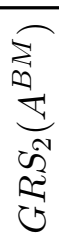 & 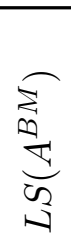 & 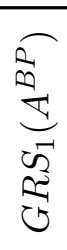 & 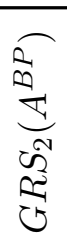 & $\frac{\overparen{\pi}}{\sqrt{2}}$ \\
\hline Anglia & 4 & 10 & 10 & 9 & 9 & 11 & 10 & 9 & 12 & 10 & 10 & 12 & 10 & 10 \\
\hline Ausztria & 27 & 30 & 29 & 28 & 25 & 33 & 28 & 26 & 34 & 30 & 26 & 34 & 33 & 29 \\
\hline Azerbajdzsán & 6 & 1 & 1 & 1 & 2 & 1 & 1 & 2 & 2 & 1 & 2 & 5 & 2 & 3 \\
\hline Belgium & 33 & 33 & 33 & 33 & 34 & 28 & 33 & 34 & 28 & 33 & 33 & 20 & 30 & 33 \\
\hline Bulgária & 21 & 25 & 25 & 24 & 23 & 25 & 24 & 23 & 24 & 23 & 22 & 21 & 19 & 21 \\
\hline Csehország & 9 & 8 & 9 & 10 & 10 & 10 & 9 & 10 & 9 & 9 & 9 & 8 & 7 & 6 \\
\hline Dánia & 26 & 27 & 27 & 30 & 32 & 24 & 29 & 32 & 23 & 28 & 31 & 19 & 26 & 30 \\
\hline Fehéroroszo. & 17 & 15 & 13 & 12 & 11 & 16 & 12 & 11 & 16 & 15 & 11 & 17 & 16 & 12 \\
\hline Finnország & 32 & 34 & 34 & 34 & 33 & 34 & 34 & 33 & 32 & 34 & 34 & 31 & 32 & 34 \\
\hline Franciaország & 3 & 2 & 2 & 2 & 1 & 3 & 2 & 1 & 4 & 3 & 1 & 7 & 4 & 1 \\
\hline Görögország & 15 & 7 & 7 & 7 & 8 & 8 & 7 & 7 & 8 & 7 & 6 & 9 & 6 & 5 \\
\hline Grúzia & 14 & 6 & 6 & 6 & 6 & 6 & 6 & 6 & 7 & 6 & 8 & 11 & 9 & 8 \\
\hline Hollandia & 8 & 11 & 12 & 14 & 17 & 7 & 13 & 17 & 3 & 11 & 15 & 1 & 5 & 11 \\
\hline Horvátország & 16 & 17 & 15 & 15 & 16 & 17 & 17 & 16 & 17 & 17 & 18 & 18 & 17 & 17 \\
\hline Izland & 28 & 29 & 32 & 32 & 31 & 29 & 32 & 31 & 29 & 29 & 30 & 28 & 28 & 28 \\
\hline Izrael & 29 & 28 & 28 & 26 & 24 & 30 & 27 & 24 & 30 & 27 & 24 & 30 & 29 & 23 \\
\hline Lengyelo. $1^{\dagger}$ & 12 & 16 & 14 & 13 & 14 & 15 & 14 & 13 & 15 & 16 & 13 & 14 & 15 & 16 \\
\hline Lengyelo. $2^{\ddagger}$ & 23 & 22 & 22 & 23 & 26 & 22 & 23 & 25 & 22 & 24 & 25 & 24 & 23 & 24 \\
\hline Lengyelo. $3^{*}$ & 24 & 31 & 31 & 31 & 29 & 31 & 31 & 30 & 31 & 32 & 32 & 32 & 31 & 32 \\
\hline Litvánia & 34 & 23 & 23 & 25 & 30 & 19 & 25 & 29 & 18 & 25 & 29 & 16 & 22 & 27 \\
\hline Macedónia & 35 & 37 & 37 & 37 & 37 & 36 & 37 & 37 & 36 & 36 & 37 & 35 & 36 & 36 \\
\hline Magyarország & 7 & 5 & 5 & 5 & 5 & 5 & 5 & 5 & 5 & 4 & 5 & 3 & 3 & 4 \\
\hline Montenegró & 30 & 18 & 18 & 19 & 21 & 18 & 19 & 22 & 19 & 21 & 23 & 27 & 27 & 25 \\
\hline Németország & 10 & 20 & 20 & 20 & 18 & 20 & 20 & 19 & 20 & 18 & 19 & 22 & 18 & 19 \\
\hline Norvégia & 36 & 35 & 35 & 35 & 35 & 35 & 35 & 35 & 35 & 35 & 35 & 36 & 35 & 35 \\
\hline Olaszország & 13 & 12 & 11 & 11 & 12 & 12 & 11 & 12 & 14 & 12 & 12 & 15 & 14 & 14 \\
\hline Oroszország & 1 & 3 & 4 & 4 & 4 & 2 & 4 & 4 & 1 & 2 & 3 & 2 & 1 & 2 \\
\hline Örményország & 2 & 4 & 3 & 3 & 3 & 4 & 3 & 3 & 6 & 5 & 4 & 13 & 11 & 9 \\
\hline Románia & 19 & 14 & 17 & 17 & 15 & 13 & 15 & 15 & 11 & 13 & 14 & 4 & 13 & 13 \\
\hline Skócia & 37 & 36 & 36 & 36 & 36 & 37 & 36 & 36 & 37 & 37 & 36 & 37 & 37 & 37 \\
\hline Spanyolország & 11 & 19 & 21 & 21 & 22 & 21 & 21 & 21 & 21 & 20 & 21 & 23 & 20 & 22 \\
\hline Svájc & 31 & 32 & 30 & 29 & 27 & 32 & 30 & 27 & 33 & 31 & 28 & 33 & 34 & 31 \\
\hline Svédország & 25 & 26 & 26 & 27 & 28 & 26 & 26 & 28 & 25 & 26 & 27 & 25 & 24 & 26 \\
\hline Szerbia & 20 & 13 & 16 & 18 & 19 & 14 & 16 & 18 & 13 & 14 & 16 & 6 & 12 & 15 \\
\hline Szlovénia & 22 & 21 & 19 & 16 & 13 & 23 & 18 & 14 & 26 & 19 & 17 & 29 & 25 & 20 \\
\hline Törökország & 18 & 24 & 24 & 22 & 20 & 27 & 22 & 20 & 27 & 22 & 20 & 26 & 21 & 18 \\
\hline Ukrajna & 5 & 9 & 8 & 8 & 7 & 9 & 8 & 8 & 10 & 8 & 7 & 10 & 8 & 7 \\
\hline Wales & 38 & 38 & 38 & 38 & 38 & 38 & 38 & 38 & 38 & 38 & 38 & 38 & 38 & 38 \\
\hline
\end{tabular}


F.IV. Függelék: Rangsorok összehasonlítói ábrái 
F.5. ábra. Következő forduló előrejelző képessége, 2013-as sakkcsapat EB

(a) Mérkőzéspont, $A^{M B}$ eredménymátrix

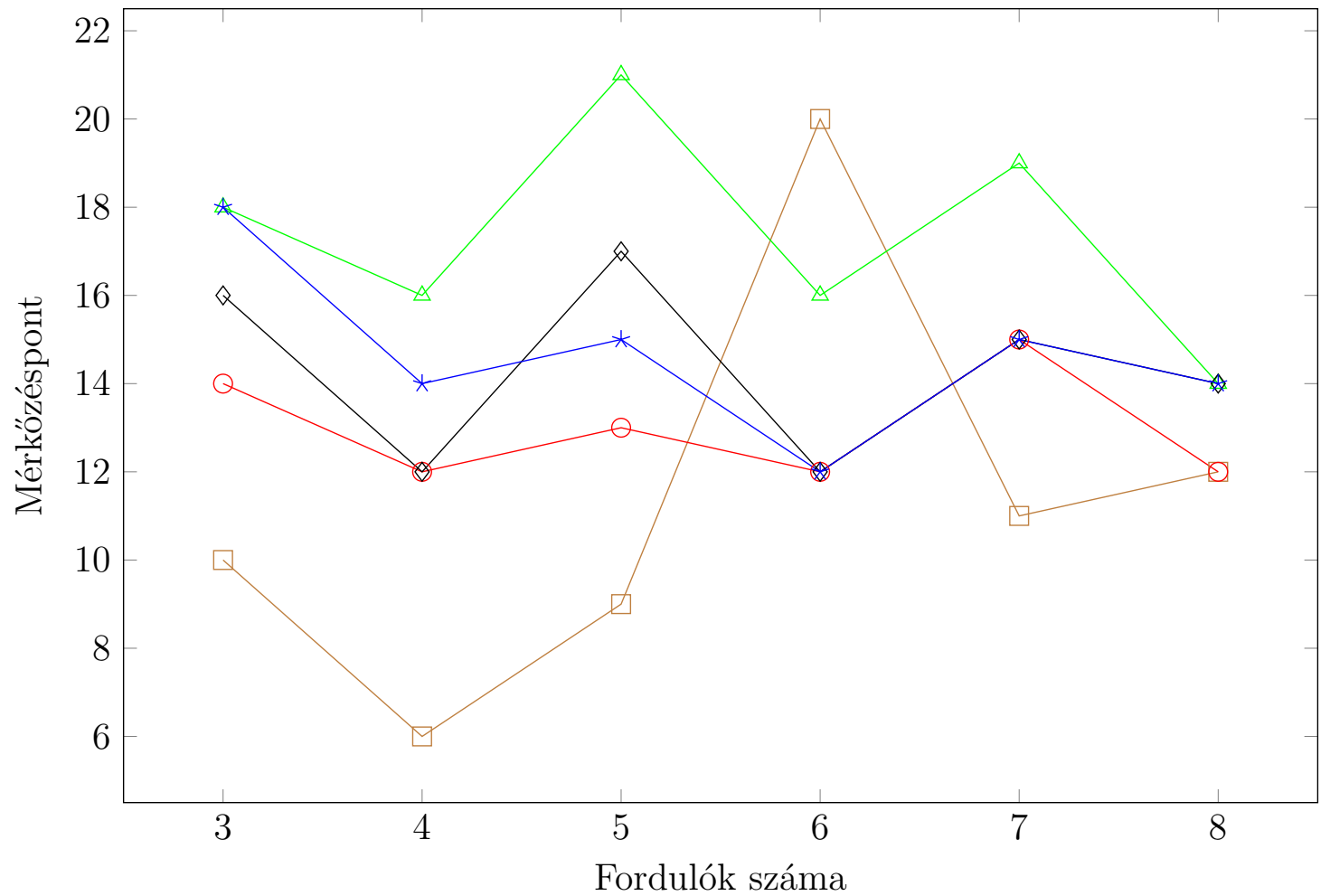

$\neg$ Start $\frown$ Off $\triangle \mathrm{G} 2 \multimap \mathrm{S} 2 \rightarrow \mathrm{L} 2$

(b) Táblapont, $A^{M B}$ eredménymátrix

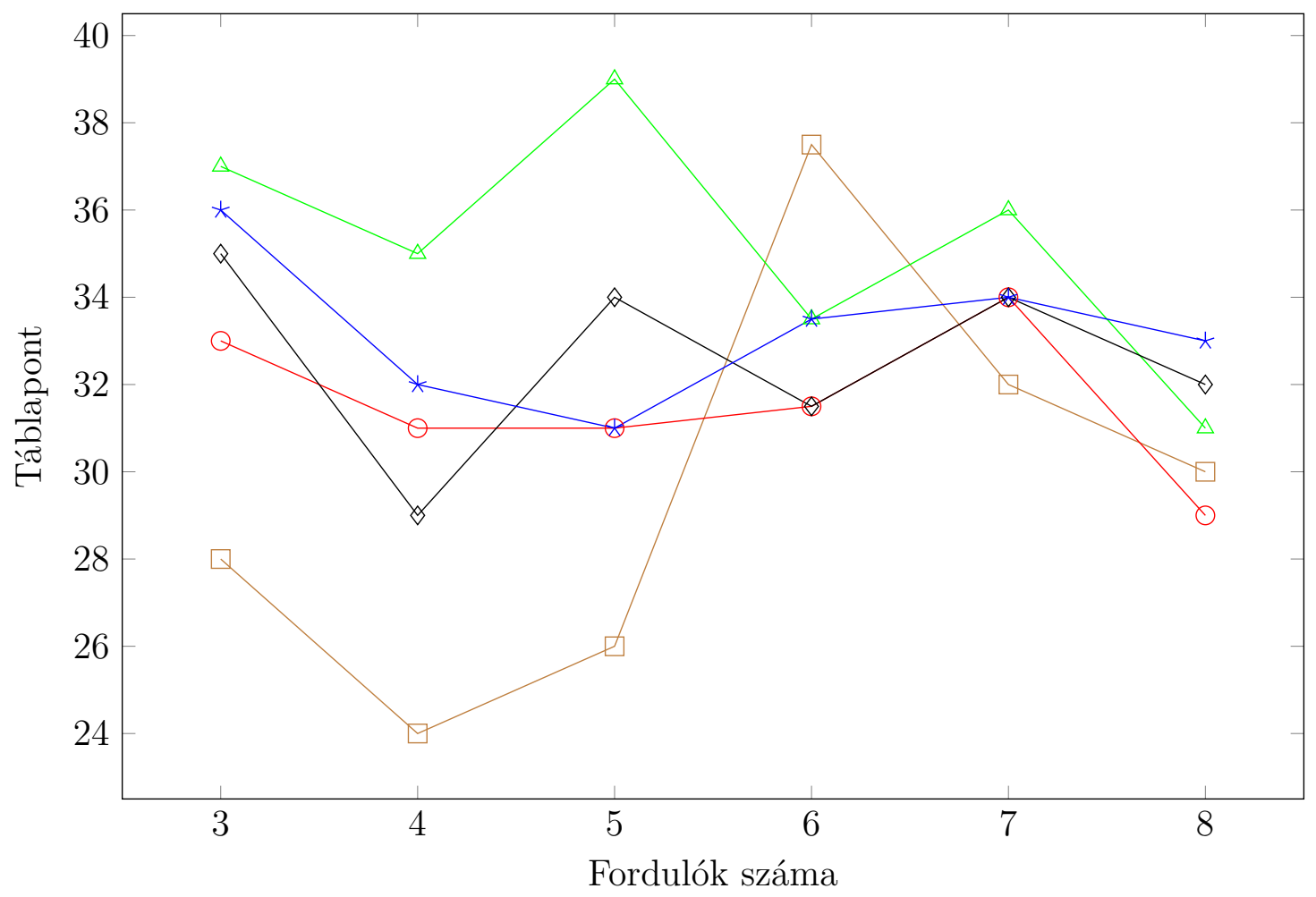

Start $\frown$ Off $\triangle \mathrm{G} 2 \multimap \mathrm{S} 2 \quad$ * L2 
F.6. ábra. Stabilitás a fordulók között, 2013-as sakkcsapat EB

(a) Kemény-távolság, $A^{M P}$ mérkőzéspont alapú eredménymátrix

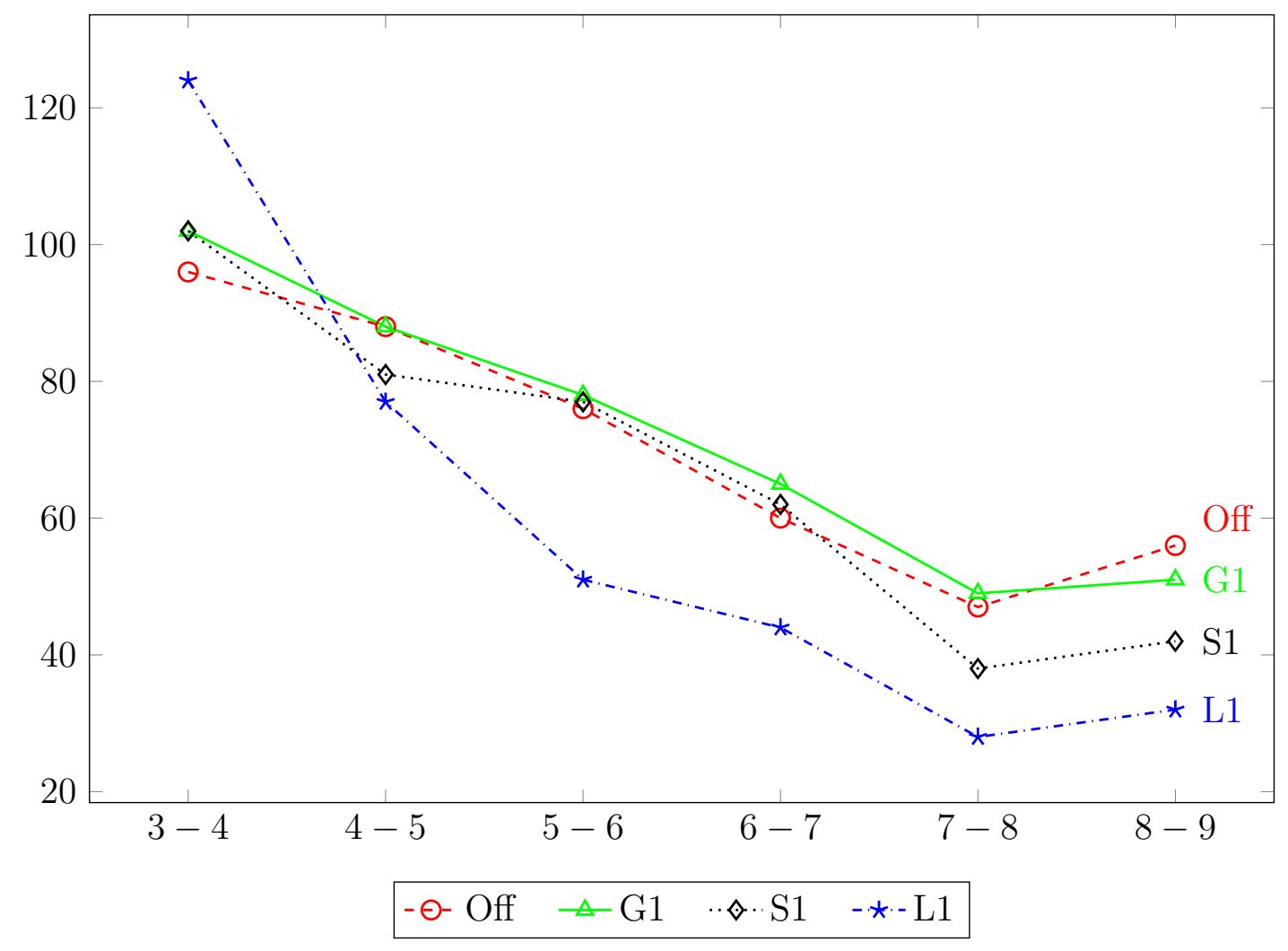

(b) Súlyozott távolság, $A^{M P}$ mérkőzéspont alapú eredménymátrix

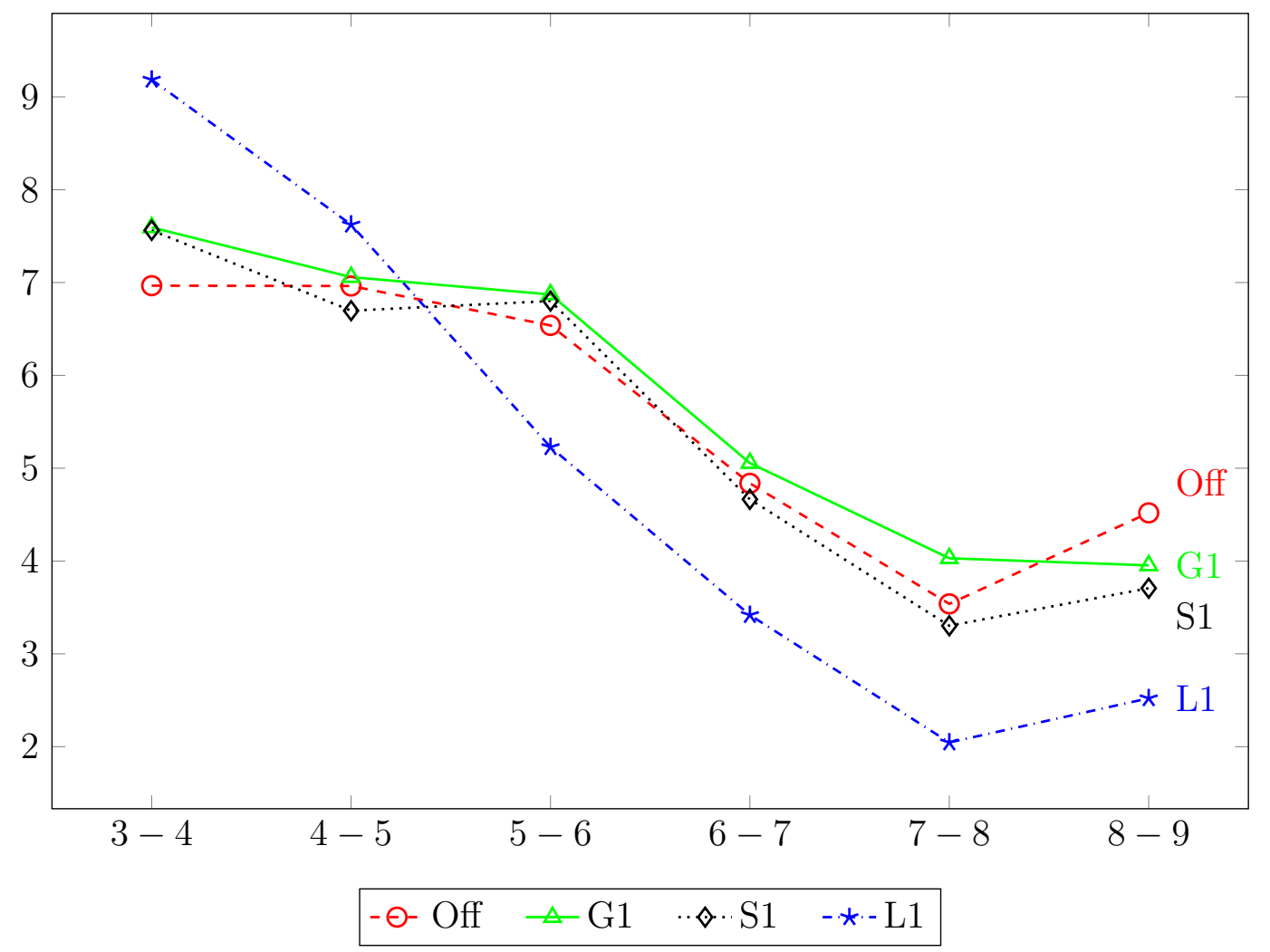




\section{F.V. Függelék: Axiómák összefoglaló táblázatai}

F.5. táblázat. Fogalmak és pontozási eljárások

\begin{tabular}{|c|c|c|}
\hline Fogalom & Definíció & Illusztráció \\
\hline Objektumhalmaz & 2.1. Definíció & - \\
\hline Egyéni páros összehasonlítási mátrix & 2.2. Definíció & - \\
\hline Preferenciaprofil & 2.3. Definíció & - \\
\hline Aggregált páros összehasonlítási mátrix & 2.4. Definíció & - \\
\hline Irreducibilitás & 2.5. Definíció & - \\
\hline \multirow[t]{2}{*}{ Rangsorolási probléma } & 2.6. Definíció & 2.1. Példa \\
\hline & 2.9. Definíció & \\
\hline Eredménymátrix & 2.7. Definíció & - \\
\hline Mérkőzésmátrix & 2.8. Definíció & - \\
\hline Speciális rangsorolási problémák & 2.10. Definíció & - \\
\hline Speciális mérkőzésmátrixok & 2.11. Definíció & - \\
\hline Multihalmaz & 2.12. Definíció & 2.2. Példa \\
\hline Ellenfél halmaz és multihalmaz & 2.13. Definíció & 2.3. Példa \\
\hline Összehasonlítások száma & 2.14. Definíció & - \\
\hline Gráfelméleti alapfogalmak & 2.15. Definíció & - \\
\hline Összehasonlítási multigráf & 2.16. Definíció & - \\
\hline Összefüggő rangsorolási probléma & 2.17. Definíció & - \\
\hline Rangsor & 2.18. Definíció & - \\
\hline Lineáris rendezés & 2.19. Definíció & - \\
\hline Rangsorolási módszer & 2.20. Definíció & - \\
\hline Általános pontozási eljárás & 2.21. Definíció & - \\
\hline Pontozási eljárás & 2.22. Definíció & - \\
\hline Arányosság & 2.23. Definíció & - \\
\hline Ekvivalencia & 2.24. Definíció & - \\
\hline Optimális lineáris rendezés & 2.25. Definíció & - \\
\hline
\end{tabular}


F.5. táblázat. Fogalmak és pontozási eljárások (folytatás)

\begin{tabular}{lll}
\hline Fogalom & Definíció & Illusztráció \\
\hline Név módszer & 3.1. Definíció & - \\
Egyenlö módszer & 3.2. Definíció & - \\
Pontszám módszer & 3.3. Definíció & 3.1. Példa \\
Általánosított sorösszeg módszer & 3.4. Definíció & 3.1. Példa \\
$\varepsilon$ észszerü választása & 3.5. Definíció & - \\
Pozíciós erő módszer & 3.6. Definíció & - \\
Legkisebb négyzetek módszere & 3.7. Definíció & 3.1. Példa \\
\hline Liga & 3.8. Definíció & 3.2. Példa \\
Ligák közötti dominancia & 3.9. Definíció & 3.3. Példa \\
\hline Kiegyensúlyozott összehasonlítási multigráf & 4.1. Definíció & 4.1 Példa \\
Általánosított Buchholz módszer & 4.2. Definíció & - \\
\hline Eredmények elfogadható transzformációja & 5.6. Definíció & 5.2 Példa \\
Objektumok lineáris rendezésének létezése & 5.13. Definíció & 5.4 . Példa \\
Döntetlen elfogadható transzformációja & 5.17. Definíció & 5.8. Példa \\
\hline Elemi körön elfogadható transzformáció & 6.3. Definíció & 6.2 . Példa \\
\hline Mérközéspont alapú eredménymátrix & 7.1. Definíció & - \\
Táblapont alapú eredménymátrix & 7.2. Definíció & - \\
Általánosított eredménymátrix & 7.3. Definíció & - \\
\hline Szavazó-alternatíva mátrix & 8.1. Definíció & - \\
\hline Eltérésfüggvény & F.II.1. Definíció & - \\
Távolságfüggvény & F.II.2. Definíció & - \\
Kemény-távolság & F.II.3. Definíció & F.II.1. Példa \\
Lineáris rendezésekből álló út & F.II.4. Definíció & - \\
Dekomponálhatóság & F.II.5. Definíció & - \\
Pozíciós semlegesség & F.II.6. Definíció & - \\
Súlyozott eltérésfüggvény & F.II.7. Definíció & - \\
Útminimalizáló súlyozott eltérésfüggvény & F.II.8. Definíció & - \\
Lehmer-függvény & F.II.9. Definíció & F.II.1. Példa \\
Súlyozott távolság & F.II.10. Definíció & - \\
\hline & & \\
\hline
\end{tabular}


F.6. táblázat. Pontozási eljárások az axiómák tükrében

\begin{tabular}{|c|c|c|c|}
\hline Tulajdonság & Korábbi megjelenés & Definíció & Pontszám $^{\dagger}$ \\
\hline$A N O$ & Young (1974) & 5.1. Definíció & $\begin{array}{l}\text { 5.1. Lemma } \\
\text { 5.2. Lemma }\end{array}$ \\
\hline$N E U$ & Young (1974) & 5.2. Definíció & 5.3. Lemma \\
\hline$C N T$ & Chebotarev (1994) & 5.3. Definíció & 5.4. Lemma \\
\hline$L R C R$ & Chebotarev (1994) & 5.4. Definíció & 5.1. Állítás \\
\hline$H O M$ & González-Díaz et al. (2014) & 5.5. Definíció & 5.5. Lemma \\
\hline$S I$ & 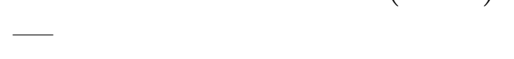 & 5.7. Definíció & 5.6. Lemma \\
\hline$C S$ & Young (1974) & 5.8. Definíció & 5.7. Lemma \\
\hline$F P$ & Slutzki és Volij (2005) & 5.9. Definíció & 5.8. Lemma \\
\hline$R C S$ & - & 5.10. Definíció & 5.9. Lemma \\
\hline$S Y M$ & González-Díaz et al. (2014) & 5.11. Definíció & 5.9. Lemma \\
\hline$I N V$ & Chebotarev (1994) & 5.12. Definíció & 5.12. Lemma \\
\hline$L O P$ & - & 5.14. Definíció & 5.9. Állítás \\
\hline$I I M$ & González-Díaz et al. (2014) & 5.15. Definíció & 5.10. Állítás \\
\hline$I I R$ & - & 5.16. Definíció & 5.14. Lemma \\
\hline$I D^{\ddagger}$ & - & 5.18. Definíció & 5.16. Lemma \\
\hline$S M$ & Bouyssou (1992) & 6.1. Definíció & 6.1. Lemma \\
\hline$C S M$ & Rubinstein (1980) & 6.2. Definíció & 6.2. Lemma \\
\hline$I C$ & Bouyssou (1992) & 6.4. Definíció & 6.4. Lemma \\
\hline$S C C$ & González-Díaz et al. (2014) & 6.5. Definíció & 6.6. Lemma \\
\hline$H T V$ & González-Díaz et al. (2014) & 6.6. Definíció & 6.6. Lemma \\
\hline HTO & - & 6.7. Definíció & 6.4. Állítás \\
\hline
\end{tabular}

Eredmények az $\mathcal{R}$-nél korlátozottabb értelmezési tartományt használó cikkek nélkül

† González-Díaz et al. (2014) eltérően definiálja a pontszám módszert

‡ Chebotarev (1994, Property 14) dinamikus monotonitás (2) feltételének kiterjesztése 
F.6. táblázat. Pontozási eljárások az axiómák tükrében (folytatás)

\begin{tabular}{|c|c|c|}
\hline Tulajdonság & Általánosított sorösszeg ${ }^{\dagger}$ & Legkisebb négyzetek \\
\hline$A N O$ & 5.1. Lemma; 5.2. Lemma & 5.1. Lemma; 5.2. Lemma \\
\hline \multirow[t]{2}{*}{$N E U$} & González-Díaz et al. (2014, 145. o.) & González-Díaz et al. $(2014,145$. o.) \\
\hline & 5.3. Lemma & 5.3. Lemma \\
\hline \multirow[t]{2}{*}{$C N T$} & Chebotarev (1994, Property 2) & 5.4. Lemma \\
\hline & 5.4. Lemma & \\
\hline \multirow[t]{2}{*}{$L R C R$} & Chebotarev (1994, Property 6) & 5.1. Állítás \\
\hline & 5.1. Állítás & \\
\hline \multirow[t]{2}{*}{$H O M$} & González-Díaz et al. (2014, 145. o.) & González-Díaz et al. $(2014,145$. o.) \\
\hline & 5.2. Állítás; 5.3. Állítás; 1. Sejtés ${ }^{1}$ & 5.5. Lemma \\
\hline$S I$ & 5.6. Lemma & 5.6. Lemma \\
\hline$C S$ & 5.4. Állítás ${ }^{2}$ & 5.4. Állítás ${ }^{2}$ \\
\hline \multirow[t]{2}{*}{$F P$} & González-Díaz et al. (2014, & González-Díaz et al. (2014, \\
\hline & Proposition 4.2); 5.8. Lemma & Corollary 4.3$)$; 5.8. Lemma \\
\hline$R C S$ & $\begin{array}{l}\text { 5.10. Lemma; 5.6. Állítás; } \\
\text { 2. Sejtés }{ }^{1}\end{array}$ & 5.5. Állítás \\
\hline \multirow[t]{2}{*}{$S Y M$} & González-Díaz et al. $(2014,150$. o.) & González-Díaz et al. $(2014,150$. o.) \\
\hline & 5.9. Lemma & 5.9. Lemma \\
\hline \multirow[t]{2}{*}{$I N V$} & Chebotarev (1994, Property 7) & González-Díaz et al. (2014, \\
\hline & 5.13. Lemma & Proposition 4.6); 5.13. Lemma \\
\hline$L O P$ & 5.9. Állítás; 3. Sejtés & 5.1. Tétel; 4. Sejtés \\
\hline$I I M$ & González-Díaz et al. (2014, & González-Díaz et al. (2014, \\
\hline$I I R$ & $\begin{array}{l}\text { Example 6.1); 5.15. Lemma } \\
\text { 5.11. Állítás }\end{array}$ & $\begin{array}{l}\text { Example 6.1); 5.15. Lemma } \\
\text { 5.11. Állítás }\end{array}$ \\
\hline \multirow[t]{2}{*}{$I D^{\ddagger}$} & 5.13. Állítás; 5.14. Állítás; 5. Sejtés & 5.13. Állítás; 5.14. Állítás; \\
\hline & & 5.15. Állítás \\
\hline \multirow[t]{2}{*}{$S M$} & Chebotarev (1994, Property 11) & (González-Díaz et al., 2014, \\
\hline & 6.1. Lemma & 159-160. о.); 6.3. Lemma ${ }^{3}$ \\
\hline \multirow{2}{*}{$\begin{array}{l}C S M \\
I C\end{array}$} & 6.2. Lemma & 6.1. Állítás ${ }^{3}$ \\
\hline & 6.4. Lemma & 6.4. Lemma \\
\hline \multirow[t]{2}{*}{$S C C$} & Chebotarev (1994, Property 3) & González-Díaz et al. (2014, \\
\hline & 6.6. Lemma & Proposition 5.3); 6.6. Lemma \\
\hline \multirow[t]{2}{*}{$H T V$} & Chebotarev (1994, Property 10) & González-Díaz et al. (2014, \\
\hline & 6.6. Lemma & Proposition 5.3); 6.6. Lemma \\
\hline HTO & 6.4. Állítás & 6.4. Állítás \\
\hline
\end{tabular}

† González-Díaz et al. (2014) csak az $\bar{\varepsilon}=[1 / m(n-2)]$ esetet vizsgálja

‡ Chebotarev (1994, Property 14) dinamikus monotonitás (2) feltételének kiterjesztése

${ }^{1}(N, A, M) \in \mathcal{R}_{R}^{n}$ körmérkőzéses rangsorolási probléma esetén: 6.7. Lemma

${ }^{2}(N, A, M) \in \mathcal{R}_{R}^{n}$ körmérkőzéses rangsorolási probléma esetén : 6.8. Lemma

${ }^{3}(N, A, M) \in \mathcal{R}_{R}^{n}$ körmérkőzéses rangsorolási probléma esetén: 6.9. Lemma 
F.7. táblázat. Tulajdonságok kapcsolata

\begin{tabular}{lll}
\hline Összefüggés & Értelmezési tartomány & Bizonyítás \\
\hline$L R C R \Rightarrow S I$ & $(N, A, M) \in \mathcal{R}^{n}$ & 5.1. Következmény \\
$C S \Rightarrow F P$ & $(N, A, M) \in \mathcal{R}^{n}$ & 5.2. Következmény \\
$C S \Rightarrow R C S$ & $(N, A, M) \in \mathcal{R}^{n}$ & 5.3. Következmény \\
$C S \Rightarrow H O M^{\dagger}$ & $(N, A, M) \in \mathcal{R}^{n}$ & 5.4. Következmény \\
$R C S \Rightarrow H O M^{\dagger}$ & $(N, A, M) \in \mathcal{R}^{n}$ & 5.4. Következmény \\
$I N V \Rightarrow S Y M$ & $(N, A, M) \in \mathcal{R}^{n}$ & 5.5. Következmény \\
$C S+S Y M \Rightarrow I N V$ & $(N, A, M) \in \mathcal{R}^{n}$ & 5.7. Állítás \\
$R C S+S Y M \Rightarrow I N V$ & $(N, A, M) \in \mathcal{R}^{n}$ & 5.7. Állítás \\
$L R C R+S Y M \Rightarrow I N V$ & $(N, A, M) \in \mathcal{R}^{n}$ & 5.8. Állítás \\
$N E U+C S+S Y M \Rightarrow I I M$ & $(N, A, M) \in \mathcal{R}^{n}$ & 5.2. Tétel \\
$N E U+R C S+S Y M \Rightarrow I I R$ & $(N, A, M) \in \mathcal{R}^{n}$ & 5.12. Állítás \\
$I I M \Rightarrow I I R$ & $(N, A, M) \in \mathcal{R}^{n}$ & 5.6. Következmény \\
$I I M \Rightarrow I D$ & $(N, A, M) \in \mathcal{R}^{n}$ & 5.7. Következmény \\
$S M \Rightarrow C S M$ & $(N, A, M) \in \mathcal{R}^{n}$ & 6.1. Következmény \\
$N E U \cap S M \cap I C \neq \emptyset^{1}$ & $(N, A, M) \in \mathcal{R}_{R}^{n}$ & 6.2. Állítás ${ }^{\ddagger}$ \\
$N E U \cap S M \cap I C \neq \emptyset^{2}$ & $(N, A, M) \in \mathcal{R}_{B}^{n}$ & 6.3. Állítás ${ }^{\ddagger}$ \\
$N E U \cap S M \cap I C \neq \emptyset^{2}$ & $(N, A, M) \in \mathcal{R}_{U}^{n}$ & 6.3. Állítás ${ }^{\ddagger}$ \\
$H T V \Rightarrow S C C$ & $(N, A, M) \in \mathcal{R}^{n}$ & 6.2. Következmény \\
$H T O \Rightarrow S C C$ & $(N, A, M) \in \mathcal{R}^{n}$ & 6.3. Következmény \\
$H T O \Rightarrow H T V$ & $(N, A, M) \in \mathcal{R}^{n}$ & 6.3. Következmény \\
\hline
\end{tabular}

Korábbi eredmények a szövegben

† Csak pozitív egész $k$-kra

₹ Függetlenség: 6.5. Lemma

${ }^{1}$ Csak a pontszám módszer (karakterizáció)

${ }^{2}$ Például a pontszám és az általánosított sorösszeg 


\section{Idézetek}

\section{Az idézetek forrása}

A fejezetek elején szereplő idézetek fellelhetősége:

Mottó (VI. oldal) http://www.histoire-france.net/annexes/citations.

Köszönetnyilvánítás (VII. oldal) - Voltaire [1965]: XII. Károly svéd király története. Európa Könyvkiadó, Budapest. 286. o.

1. fejezet-http://en.wikiquote.org/wiki/Ernest_Rutherford.

2. fejezet-Bordes, G. [1976]: Consistency, rationality and collective choice. The Review of Economic Studies, 43(3):451-457. 453. o.

DOI: http://dx.doi.org/10.2307/2297222.

4. fejezet - http://www.spiegel.de/kultur/literatur/beruehmte-abschiedsworte-otto-lilienthal-1848-1896-a-475916.html.

4. fejezet-Chebotarev és Shamis (1999, 206. o.).

5. fejezet-Bouyssou (2004, 270. o.).

6. fejezet-Hamilton, R. F. és Herwig, H. H. (szerk.) [2009]: War Planning 1914. Cambridge University Press, Cambridge (UK). 142. o.

DOI: http://dx.doi.org/10.1017/cbo9780511642371.

7. fejezet - http://www.zitate.eu/de/zitat/186085/helmuth-von- moltke.

8. fejezet - http://www.notablebiographies.com/supp/Supplement-Mi-So/Ritchie-Dennis.html.

9. fejezet - Wiegand K. és Czanyuga J. (szerk.) [1864]: 1168 Latin közmondás gyüjteménye - Iskolai és házi használatra. Lampel Róbert, Pest. 1048. URL: http://mek.oszk.hu/07500/07576/07576.pdf. 


\section{Az idézetek fordítása}

A nem angol nyelvű idézetek fordítása:

Mottó (VI. oldal) - Francia; lásd Lefebvre, G. [1975]: Napóleon. Gondolat, Budapest. 487. o.

Il n'y a que deux puissances au monde, le sabre et l'esprit: à la longue, le sabre est toujours vaincu par l'esprit. $\approx$ Csak két hatalom van a világon, a kard és a szellem; hosszú távon a szellem mindig legyözi a kardot.

3. fejezet - Német; saját, nem szó szerinti átirat Kleine Opfer müssen gebracht werden. $\approx$ A kis áldozatokat meg kell hozni.

7. fejezet-Német; saját, nem szó szerinti átirat Man muß das Unmögliche fordern, damit das Mögliche erreicht wird. $\approx A$ lehetetlen megkövetelésével elérhetö a lehetséges.

4 9. fejezet - Latin; lásd a megadott forrást Sero venientibus ossa. $\approx A$ későn érkezők csak a csontokat kapják. 


\section{Irodalomjegyzék}

Ali, I., Cook, W. D. és Kress, M. [1986]: On the minimum violations ranking of a tournament. Management Science, 32(6):660-672.

DOI: http://dx.doi.org/10.1287/mnsc.32.6.660.

Altman, A. és Tennenholtz, M. [2005]: Ranking systems: the PageRank axioms. In EC '05: Proceedings of the 6th ACM conference on Electronic commerce, pp. 1-8. DOI: http://dx.doi.org/10.1145/1064009.1064010.

Altman, A. és Tennenholtz, M. [2008]: Axiomatic foundations for ranking systems. Journal of Artificial Intelligence Research, 31(1):473-495.

DOI: http://dx.doi.org/10.1613/jair.2306.

Anderson, W. N. és Morley, T. D. [1985] : Eigenvalues of the Laplacian of a graph. Linear and Multilinear Algebra, 18(2):141-145.

DOI: http://dx.doi .org/10.1080/03081088508817681.

Arrow, K. J. [1951]: Social choice and invidual values. Wiley, New York.

URL: http: //cowles. econ.yale.edu/P/cm/m12/.

Avery, C. N., Glickman, M. E., Hoxby, C. M. és Metrick, A. [2013]: A revealed preference ranking of U.S. colleges and universities. The Quarterly Journal of Economics, 128(1):425-467. DOI: http://dx.doi.org/10.1093/qje/qjs043.

Bassett, Jr. G. W. [1997]: Robust sports ratings based on least absolute errors. The American Statistician, 51(2):99-105.

DOI: http://dx.doi.org/10.1080/00031305.1997.10473938.

Borda, M. de [1781]: Mémoire sur les élections au scrutin. Mémoires de l'Académie Royale des Sciences.

URL: http://gerardgreco.free.fr/IMG/pdf/MA_c_moire-Borda-1781.pdf.

Borm, P., van den Brink, R. és Slikker M. [2002] : An iterative procedure for evaluating digraph competitions. Annals of Operations Research, 109(1-4):61-75.

DOI: http://dx.doi.org/10.1023/A:1016339832755. 
Bouyssou, D. [1992]: Ranking methods based on valued preference relations: a characterization of the net flow method. European Journal of Operational Research, 60(1):61-67. DOI: http://dx.doi .org/10.1016/0377-2217(92)90333-5.

Bouyssou, D. [2004]: Monotonicity of 'ranking by choosing': a progress report. Social Choice and Welfare, 23(2):249-273.

DOI: http://dx.doi.org/10.1007/s00355-003-0250-x.

Bozóki, S., Fülöp, J. és Rónyai, L. [2010]: On optimal completion of incomplete pairwise comparison matrices. Mathematical and Computer Modelling, 52(1-2): 318-333. DOI: http://dx.doi.org/10.1016/j.mcm.2010.02.047.

Bozóki, S., Csató, L., Rónyai, L. és Tapolcai, J. [2014]: Robust peer review decision process. Kézirat.

Bradley, R. A. és Terry, M. E. [1952]: Rank analysis of incomplete block designs: I. The method of paired comparisons. Biometrika, 39(3/4):324-345.

DOI: http://dx.doi.org/10.2307/2334029.

Brin, S. és Page, L. [1998]: The anatomy of a large-scale hypertextual web search engine. Computer networks and ISDN systems, 30(1):107-117.

DOI: http://dx.doi.org/10.1016/S0169-7552(98)00110-X.

Brozos-Vázquez, M., Campo-Cabana, M. A., Díaz-Ramos, J. C. és González-Díaz, J. [2008] Ranking participants in tournaments by means of rating functions. Journal of Mathematical Economics, 44(11):1246-1256.

DOI: http://dx.doi.org/10.1016/j.jmateco.2008.03.002.

Brozos-Vázquez, M., Campo-Cabana, M. A., Díaz-Ramos, J. C. és González-Díaz, J. [2010]: Recursive tie-breaks for chess tournaments. URL: http://eio.usc . es/pub/julio/Desempate/Performance_Recursiva_en.htm.

Can, B. [2012]: Weighted distances between preferences. Technical Report RM/12/056, Maastricht University School of Business and Economics, Graduate School of Business and Economics.

URL: http: //edocs .ub.unimaas.nl/loader/file.asp?id=1728.

Can, B. [2014]: Weighted distances between preferences. Journal of Mathematical Economics, 51:109-115.

DOI: http://dx.doi.org/10.1016/j.jmateco.2014.01.002.

Can, B. és Storcken, T. [2013]: A re-characterization of the Kemeny distance. Technical Report RM/13/009, Maastricht University School of Business and 
Economics, Graduate School of Business and Economics. URL: http://pub. maastrichtuniversity.nl/5bc99848-9276-4cd5-95fc-88162618ab20.

Charon, I. és Hudry, O. A survey on the linear ordering problem for weighted or unweighted tournaments. 4OR, 5(1):5-60, 2007.

DOI: http://dx.doi.org/10.1007/s10288-007-0036-6.

Charon, I. és Hudry, O. [2010]: An updated survey on the linear ordering problem for weighted or unweighted tournaments. Annals of Operations Research, 175(1): 107-158. DOI: http://dx.doi.org/10.1007/s10479-009-0648-7.

Chebotarev, P. [1989] An extension of the method of string sums for incomplete pairwise comparisons (oroszul). Avtomatika $i$ Telemekhanika, 50(8):125-137.

URL: http://mi .mathnet.ru/eng/at6388.

Chebotarev, P. [1994] : Aggregation of preferences by the generalized row sum method. Mathematical Social Sciences, 27(3):293-320.

DOI: http://dx.doi.org/10.1016/0165-4896(93)00740-L.

Chebotarev, P. [2012]: The walk distances in graphs. Discrete Applied Mathematics, 160(10):1484-1500. DOI: http://dx.doi.org/10.1016/j.dam.2012.02.015.

Chebotarev, P. és Agaev, R. [2002]: Forest matrices around the Laplacian matrix. Linear Algebra and its Applications, 356(1-3):253-274.

DOI: http://dx.doi .org/10.1016/S0024-3795(02)00388-9.

Chebotarev, P. és Shamis, E. [1997]: Constructing an objective function for aggregating incomplete preferences. In Tangian, A. és Gruber, J. (szerk.): Constructing Scalar-Valued Objective Functions. Lecture Notes in Economics and Mathematical Systems, volume 453. Springer, Berlin-Heidelberg, pp. 100-124.

DOI: http://dx.doi.org/10.1007/978-3-642-48773-6_8.

Chebotarev, P. és Shamis, E. [1998a]: Characterizations of scoring methods for preference aggregation. Annals of Operations Research, 80:299-332.

DOI: http://dx.doi.org/10.1023/A:1018928301345.

Chebotarev, P. és Shamis, E. [1998b]: On proximity indices for vertices of graphs (oroszul). Avtomatika i Telemekhanika, 59(10):113-133.

URL: http://mi . mathnet.ru/eng/at2808.

Chebotarev, P. és Shamis, E. [1999]: Preference fusion when the number of alternatives exceeds two: indirect scoring procedures. Journal of the Franklin Institute, 336(2):205-226. DOI: http://dx.doi .org/10.1016/S0016-0032 (98)00017-9. 
Coleman, B. J. [2005]: Minimizing game score violations in college football rankings. Interfaces, 35(6):483-496. DOI: http://dx.doi .org/10.1287/inte.1050.0172.

Condorcet, M. le Marquis de. [1785]: Essai sur l'application de l'analyse à la probabilité des décisions rendues à la pluralité des voix. De l'imprimerie royale, Paris. URL: http://gallica.bnf.fr/ark:/12148/bpt6k417181.

Conner, G. R. és Grant, C. P. [2000]: An extension of Zermelo's model for ranking by paired comparisons. European Journal of Applied Mathematics, 11(3):225-247. DOI: http://dx.doi.org/10.1017/s0956792500004150.

Conner, G. R. és Grant, C. P. [2009]: Neighborhood monotonicity, the extended Zermelo model, and symmetric knockout tournaments. Discrete Mathematics, 309 (12):3998-4010. DOI: http://dx.doi.org/10.1016/j.disc.2008.11.026.

Copeland, A. H. [1951]: A reasonable social welfare function. Seminar on Applications of Mathematics to social sciences, University of Michigan.

Cramer, G. [1750]: Introduction à l'analyse des lignes courbes algébriques. Frères Cramer \& Cl. Philibert, Genève.

URL: http://books.google.hu/books/about/Introduction_\%C3\%AO_l_ analyse_des_lignes_cou.html?id=HzcVAAAAQAAJ\&redir_esc=y.

Crawford, G. és Williams, C. [1980]: Analysis of subjective judgment matrices. Interim report R-2572-AF, Rand Corporation, Santa Monica.

URL: http://oai.dtic.mil/oai/oai?verb=getRecord\&metadataPrefix= $=$ html\&identifier=ADA087851.

Crawford, G. és Williams, C. [1985]: A note on the analysis of subjective judgment matrices. Journal of Mathematical Psychology, 29(4):387-405.

DOI: http://dx.doi.org/10.1016/0022-2496(85)90002-1.

Csató, L. [2012a]: A pairwise comparison approach to ranking in chess team championships. In Fülöp P. (szerk.): Tavaszi Szél 2012 Konferenciakötet. Doktoranduszok Országos Szövetsége, Budapest, 514-519. o.

Csató, L. [2012b]: A paired comparisons ranking and Swiss-system chess team tournaments. Magyar Közgazdaságtudományi Egyesület VI. éves konferencia. URL: http://media. coauthors.net/konferencia/conferences/7/LLSM_ Buch_ranking_-. pdf.

Csató, L. [2013a]: Ranking by pairwise comparisons for Swiss-system tournaments. Central European Journal of Operations Research, 21(4):783-803.

DOI: http://dx.doi.org/10.1007/s10100-012-0261-8. 
Csató L. [2013b]: Páros összehasonlításon alapuló pontozási eljárások monotonitása: önkonzisztencia és önkonzisztens monotonitás. Adalékok a pontozási eljárások axiomatikus tárgyalásához. Műhelytanulmány (working paper), Budapesti Corvinus Egyetem, Budapest. URL: http://unipub.lib.uni-corvinus.hu/1399/.

Csató L. [2013c] : Rangsorolás páros összehasonlításokkal. Kiegészítések a felvételizői preferencia-sorrendek módszertanához. Közgazdasági Szemle, LX(12):1333-1353. URL: http: //unipub.lib.uni-corvinus.hu/1395/.

Csató L. [2013d]: Páros összehasonlításokon alapuló rangsorolási módszerek. Szigma, XLIV(3-4):155-198. URL: http://unipub.lib.uni-corvinus.hu/1645/.

Csató, L. [2014a]: A graph interpretation of the least squares ranking method. Social Choice and Welfare. Megjelenés alatt.

DOI: http://dx.doi.org/10.1007/s00355-014-0820-0.

Csató, L. [2014b]: Additive and multiplicative properties of scoring methods for preference aggregation. Corvinus Economics Working Papers 3/2014, Corvinus University of Budapest, Budapest.

URL: http: //unipub.lib.uni-corvinus.hu/1562/.

Csató L. [2014c]: Svájci rendszerű sakk csapatversenyek rangsorolása. Mühelytanulmány (working paper), Budapesti Corvinus Egyetem, Budapest.

URL: http: //unipub.lib.uni-corvinus.hu/1604/.

Daniels, H. E. [1969] : Round-robin tournament scores. Biometrika, 56(2):295-299. DOI: http://dx.doi.org/10.1093/biomet/56.2.295.

David, H. A. [1987]: Ranking from unbalanced paired-comparison data. Biometrika, 74(2):432-436. DOI: http://dx.doi.org/10.1093/biomet/74.2.432.

de Graan, J. G. [1980]: Extensions of the multiple criteria analysis method of T.L. Saaty. National Institute for Water Supply, Voorburg.

Dodd, F. J., Donegan, H. A. és McMaster, T. B. M. [1995]: Inverse inconsistency in analytic hierarchies. European Journal of Operational Research, 80(1):86-93.

DOI: http://dx.doi .org/10.1016/0377-2217(94)e0342-9.

Einstein, A. és Grossmann, M. [1914]: Kovarianzeigenschaften der Feldgleichungen der auf die verallgemeinerte Relativitätstheorie gegründeten Gravitationstheorie. Zeitschrift für Mathematik und Physik, 63:215-225.

Éltető Ö. és Köves P. [1964]: Egy nemzetközi összehasonlításoknál fellépő indexszámítási problémáról. Statisztikai Szemle, 42(5):507-518. 
URL: http://www.ksh.hu/statszemle_archive/viewer.html?ev=1964\&szam= $=05 \& o l d=53 \& l a p=12$.

European Chess Union (ECU) [2012]: Tournament Rules.

URL: http://europechess.net/index.php?option=com_content\&view= $=$ article\&id=9\&Itemid $=15$.

European Chess Union (ECU) [2013]: Tournament Rules.

URL: http://etcc2013.com/wp-content/uploads/2013/06/ETCC-2013-tournament-rules-June-06-2013.pdf.

Fédération Internationale des Échecs (FIDE) [2014]: Handbook.

URL: http://www.fide.com/fide/handbook.html.

Fisher, I. [1922]: The making of index numbers: a study of their varieties, tests, and reliability. Houghton Mifflin, Boston.

URL: https://archive.org/details/makingindexnumb00fishgoog.

Gale, D. és Shapley, L. S. [1962]: College admissions and the stability of marriage. The American Mathematical Monthly, 69(1):9-15.

DOI: http://dx.doi.org/10.2307/2312726

Garfield, E. [1955]: Citation indexes for science. A new dimension in documentation through association of ideas. Science, 122(3959):108-111.

DOI: http://dx.doi.org/10.1126/science.122.3159.108.

Geršgorin, S. [1931]: Über die Abgrenzung der Eigenwerte einer Matrix. Bulletin de l'Académie des Sciences de l'URSS. Classe des sciences mathématiques et naturelles, 6:749-754. URL: http://mi.mathnet.ru/eng/izv5235.

González-Díaz, J., Hendrickx, R. és Lohmann, E. [2014] : Paired comparisons analysis: an axiomatic approach to ranking methods. Social Choice and Welfare, 42(1): 139-169. DOI: http://dx.doi.org/10.1007/s00355-013-0726-2.

Gulliksen, H. [1956]: A least squares solution for paired comparisons with incomplete data. Psychometrika, 21(2):125-134.

DOI: http://dx.doi.org/10.1007/BF02289093.

Gutman, I. és Xiao, W. [2004]: Generalized inverse of the Laplacian matrix and some applications. Bulletin: Classe des sciences mathématiques et naturalles. Sciences mathématiques, 129(29):15-23.

DOI: http://dx.doi .org/10.2298/bmat0429015g. 
Hansson, B. és Sahlquist, H. [1976]: A proof technique for social choice with variable electorate. Journal of Economic Theory, 13(2):193-200.

DOI: http://dx.doi.org/10.1016/0022-0531(76)90014-4.

Harker, P. T. [1987]: Incomplete pairwise comparisons in the analytic hierarchy process. Mathematical Modelling, 9(11):837-848.

DOI: http://dx.doi.org/10.1016/0270-0255(87)90503-3.

Herings, P. J.-J., van der Laan, G. és Talman, D. [2005]: The positional power of nodes in digraphs. Social Choice and Welfare, 24(3):439-454.

DOI: http://dx.doi.org/10.1007/s00355-003-0308-9.

Horst, P. [1932]: A method for determining the absolute affective value of a series of stimulus situations. Journal of Educational Psychology, 23(6):418-440.

DOI: http://dx.doi.org/10.1037/h0070134.

Horváth Á., Körösi G. és Schepp Z. [2013]: Doktoranduszhallgatók Nyári Mühelye: MKE-PTE KTK, Pécs, 2013. június 28-29. Közgazdasági Szemle, LX (7-8):903-911. URL: http://epa.oszk.hu/00000/00017/00205/pdf/EPA00017_ kozgazdasagi_szemle_2013_07-08_903-911.pdf.

Hudry, O. [2009]: A survey on the complexity of tournament solutions. Mathematical Social Sciences, 57(3):292-303.

DOI: http://dx.doi.org/10.1016/j.mathsocsci.2008.12.002.

Jeremic, V. M. és Radojicic, Z. [2010]: A new approach in the evaluation of team chess championships rankings. Journal of Quantitative Analysis in Sports, 6(3): Article 7. DOI: http://dx.doi.org/10.2202/1559-0410.1257.

Jiang, X., Lim, L.-H., Yao, Y. és Ye, Y. [2011] : Statistical ranking and combinatorial Hodge theory. Mathematical Programming, 127(1):203-244.

DOI: $10.1007 / \mathrm{s} 10107-010-0419-\mathrm{x}$.

Kaiser, H. F. és Serlin, R. C. [1978]: Contributions to the method of paired comparisons. Applied Psychological Measurement, 2(3):423-432.

DOI: http://dx.doi .org/10.1177/014662167800200317.

Katz, L. [1953] : A new status index derived from sociometric analysis. Psychometrika, 18(1):39-43. DOI: http://dx.doi .org/10.1007/BF02289026.

Kemeny, J. G. [1959]: Mathematics without numbers. Daedalus, 88(4):577-591.

URL: http://www. jstor. org/stable/20026529. 
Kemeny, J. G. és Snell, L. J. [1962] : Preference ranking: an axiomatic approach. In Mathematical models in the social sciences. Ginn, New York, pp. 9-23.

URL: http://books.google.hu/books/about/Mathematical_Models_in_the_ Social_Scienc.html?id=yXYrAAAAIAAJ\&redir_esc=y.

Kendall, M. G. [1938]: A new measure of rank correlation. Biometrika, 30(1/2): 81-93. DOI: http://dx.doi.org/10.2307/2332226.

Kendall, M. G. [1955]: Further contributions to the theory of paired comparisons. Biometrics, 11(1):43-62. DOI: http://dx.doi.org/10.2307/3001479.

Kóczy, L. Á. és Nichifor, A. [2013]: The intellectual influence of economic journals: quality versus quantity. Economic Theory, 52(3):863-884.

DOI: http://dx.doi.org/10.1007/s00199-012-0708-0.

Kóczy, L. Á. és Strobel, M. [2010]: The world cup of economics journals: A ranking by a tournament method. IEHAS Discussion Papers 1018, Institute of Economics, Hungarian Academy of Sciences.

URL: http://econ. core. hu/file/download/MTDP/MTDP1018. pdf.

Kovács E. (szerk.) [2011]: Pénzügyi adatok statisztikai elemzése. 4., bővített kiadás. Tanszék Kft., Budapest.

Körösi G. és Schepp Z. [2014] : Doktoranduszhallgatók II. Nyári Mühelye: MKE-PTE KTK, Pécs, 2014. május 28-29. Közgazdasági Szemle, LXI(9):1065-1074.

URL: https://ideas.repec.org/a/ksa/szemle/1502.html.

Kruskal, J. B. és Wish, M. [1978]: Multidimensional scaling. Quantitative applications in the social sciences, volume 11. Sage Publications, Beverly Hills and London. URL: http://books.google.hu/books/about/Multidimensional_ Scaling.html?id=ZzmIPcEXPfOC\&redir_esc=y.

Kujansuu, E., Lindberg, T. és Mäkinen, E. [1999]: The stable roommates problem and chess tournament pairings. Divulgaciones Matemáticas, 7(1):19-28.

URL: https: //eudml .org/doc/48463.

Kwiesielewicz, M. [1996]: The logarithmic least squares and the generalized pseudoinverse in estimating ratios. European Journal of Operational Research, 93(3): 611-619. DOI : 10.1016/0377-2217(95)00079-8.

Landau, E. [1895]: Zur relativen Wertbemessung der Turnierresultate. Deutsches Wochenschach, 11:366-369.

Landau, E. [1914]: Über Preisverteilung bei Spielturnieren. Zeitschrift für Mathematik und Physik, 63:192-202. 
Laslier, J.-F. [1997]: Tournament solutions and majority voting. Springer, Berlin. URL: http://books.google.hu/books/about/Tournament_Solutions_ and_Majority_Voting.html?id=vYbGAAAAIAAJ\&redir_esc=y.

London, A. és Csendes, T. [2013]: HITS based network algorithm for evaluating the professional skills of wine tasters. Carpathian Applied Mathematics Workshop 2013. URL: http://www.inf.u-szeged.hu/ csendes/saci13107.pdf.

Machado, M. P., Mora, R. és Romero-Medina, A. [2012] : Can we infer hospital quality from medical graduates' residency choices? Journal of the European Economic Association, 10(6):1400-1424.

DOI: http://dx.doi.org/10.1111/j.1542-4774.2012.01087.x.

Meyer, C. D. [2000] : Matrix analysis and applied linear algebra. Society for Industrial and Applied Mathematics, Philadelphia.

URL: http: //www.matrixanalysis.com/

Mohar, B. [1991]: The Laplacian spectrum of graphs. In Alavi, Y., Chartrand, G., Oellermann, O. R. és Schwenk, A. J. (szerk.): Graph Theory, Combinatorics, and Applications, volume 2. Wiley, New York, pp. 871-898.

URL: http://www.fmf .uni-lj.si/ mohar/Papers/Spec.pdf.

Moon, J. W. és Pullman, N. J. [1970]: On generalized tournament matrices. SIAM Review, 12(3):384-399. DOI: http://dx.doi.org/10.1137/1012081.

Morrissey, J. H. [1955]: New method for the assignment of psychometric scale values from incomplete paired comparisons. Journal of the Optical Society of America, 45(5):373-378. DOI: http://dx.doi.org/10.1364/josa.45.000373.

Mosteller, F. [1951]: Remarks on the method of paired comparisons: I. The least squares solution assuming equal standard deviations and equal correlations. Psychometrika, 16(1):3-9.

DOI: http://dx.doi.org/10.1007/978-0-387-44956-2_8.

Moulin, H. [1986]: Choosing from a tournament. Social Choice and Welfare, 3(4): 271-291. DOI: http://dx.doi.org/10.1007/bf 00292732.

Neumann, C. [1877]: Untersuchungen über das logarithmische und Newton'sche Potential. B. G. Teubner, Leipzig.

URL: https://archive.org/details/untersuchungen00neumiala.

Nitzan, S. és Rubinstein, A. [1981] : A further characterization of Borda ranking method. Public Choice, 36(1):153-158.

DOI: http://dx.doi.org/10.1007/bf00163778. 
Palacios-Huerta, I. és Volij, O. [2004]: The measurement of intellectual influence. Econometrica, 72(3):963-977.

DOI: http://dx.doi.org/10.1111/j.1468-0262.2004.00519.x.

Pasteur, R. D. [2010]: When perfect isn't good enough: Retrodictive rankings in college football. In Gallian, J. A. (szerk.): Mathematics \& Sports, Dolciani Mathematical Expositions 43. Mathematical Association of America, pp. 131-146. DOI: http://dx.doi .org/10.5948/upo9781614442004.012.

Pinski, G. és Narin, F. [1976]: Citation influence for journal aggregates of scientific publications: Theory, with application to the literature of physics. Information Processing \& Management, 12(5):297-312.

DOI: http://dx.doi .org/10.1016/0306-4573(76)90048-0.

Pintér M. [2009]: A Shapley-érték axiomatizálásai. Alkalmazott Matematikai Lapok, 26:289-315. URL: http://aml.math.bme.hu/wp-content/uploads/2014/03/26-Pinter.pdf.

Radicchi, F. Who is the best player ever? A complex network analysis of the history of professional tennis. PloS one, 6(2):e17249, 2011.

DOI: http://dx.doi.org/10.1371/journal .pone.0017249.

Rao, C. R. és Mitra, S. K. [1971]: Generalized inverse of matrices and its applications. John Wiley \& Sons, New York.

URL: http://books.google.hu/books/about/Generalized_inverse_of_ matrices_and_its.html?id=EHpdrzuKeNYC\&redir_esc=y.

Rao, D. S. P. és Timmer, M. P. [2003]: Purchasing power parities for industry comparisons using weighted Elteto-Koves-Szulc (EKS) methods. Review of Income and Wealth, 49:491-511.

DOI: http://dx.doi.org/10.1111/j.0034-6586.2003.00101.x.

Rétallér O. és Tasnádi A. [2013]: Az impakt faktor és jelentősége a közgazdaságtudományban. Múhelytanulmány (working paper), Budapesti Corvinus Egyetem, Budapest. URL: http://unipub.lib.uni-corvinus.hu/1281/.

Rubinstein, A. [1980]: Ranking the participants in a tournament. SIAM Journal on Applied Mathematics, 38(1):108-111.

DOI: http://dx.doi.org/10.1137/0138009.

Saaty, T. L. [1980]: The Analytic Hierarchy Process: planning, priority setting, resource allocation. McGraw-Hill, New York.

URL: http://books.google.hu/books/about/The_Analytic_Hierarchy_ Process.html?id=Xxi7AAAAIAAJ\&redir_esc=y. 
Shamis, E. [1994]: Graph-theoretic interpretation of the generalized row sum method. Mathematical Social Sciences, 27(3):321-333.

DOI: http://dx.doi.org/10.1016/0165-4896(93)00741-c.

Shapley, L. S. [1952]: A value for $n$-person games. P-295, Rand Corporation, Santa Monica. URL: http://www.dtic.mil/dtic/tr/fulltext/u2/604084.pdf.

Sharpe, G. és Styan, G. [1965]: A note on the general network inverse. IEEE Transactions on Circuit Theory, 12(4):632-633.

DOI: http://dx.doi.org/10.1109/tct.1965.1082504.

Slater, P. [1961]: Inconsistencies in a schedule of paired comparisons. Biometrika, 48 (3/4):303-312. DOI: http://dx.doi.org/10.2307/2332752.

Slikker, M., Borm, P. és van den Brink, R. [2012]: Internal slackening scoring methods. Theory and Decision, 72(4):445-462.

DOI: http://dx.doi.org/10.1007/s11238-011-9281-4.

Slutzki, G. és Volij, O. [2005]: Ranking participants in generalized tournaments. International Journal of Game Theory, 33(2):255-270.

DOI: http://dx.doi.org/10.1007/s00182-005-0197-5.

Slutzki, G. és Volij, O. [2006]: Scoring of web pages and tournaments - axiomatizations. Social Choice and Welfare, 26(1):75-92.

DOI: http://dx.doi.org/10.1007/s00355-005-0033-7.

Stefani, R. T. [1980]: Improved least squares football, basketball, and soccer predictions. IEEE Transactions on Systems, Man, and Cybernetics, 10(2):116-123.

DOI: http://dx.doi.org/10.1109/tsmc.1980.4308442.

Szulc, B. [1964] : Indeksy dla porównań wieloregionalnych. Przeglad Statystyczny, 3: 239-254.

Telcs A., Kosztyán Zs. T. és Török Á. [2013a]: Hallgatói preferenciasorrendek készítése az egyetemi jelentkezések alapján. Közgazdasági Szemle, LX (3):290-317. URL: http://epa.oszk.hu/00000/00017/00201/pdf/EPA00017_ kozgazdasagi_szemle_2013_03_290-317.pdf.

Telcs A., Kosztyán Zs. T. és Török Á. [2013b]: Reflexiók Csató László vitairatára. Közgazdasági Szemle, LX(12):1354-1356.

URL: $\quad$ http://epa.oszk.hu/00000/00017/00209/pdf/EPA00017_ kozgazdasagi_szemle_2013_12_1354-1356.pdf. 
Temesi J., Csató L. és Bozóki S. [2012]: Mai és régi idők tenisze. A nem teljesen kitöltött páros összehasonlítás mátrixok egy alkalmazása. In Solymosi T. és Temesi J. (szerk.): Egyensúly és optimum. Tanulmányok Forgó Ferenc 70. születésnapjára. Aula Kiadó, Budapest, 213-245. o.

URL: http://unipub.lib.uni-corvinus.hu/892/.

Thurstone, L. L. [1927]: A law of comparative judgment. Psychological Review, 34 (4):273-286. DOI: http://dx.doi .org/10.1037/h0070288.

van den Brink, R. és Gilles, R. P. [2003]: Ranking by outdegree for directed graphs. Discrete Mathematics, 271(1-3):261-270.

DOI: http://dx.doi.org/10.1016/s0012-365x(03)00050-5.

Young, H. P. [1974]: An axiomatization of Borda's rule. Journal of Economic Theory, 9(1):43-52. DOI: http://dx.doi.org/10.1016/0022-0531(74)90073-8.

Wei, T. H. [1952]: The algebraic foundations of ranking theory. PhD thesis, University of Cambridge. URL: http://books.google.hu/books/about/The_Algebraic_ Foundations_of_Ranking_The.html?id=FnEsnQEACAAJ\&redir_esc=y.

Zermelo, E. [1929]: Die Berechnung der Turnier-Ergebnisse als ein Maximumproblem der Wahrscheinlichkeitsrechnung. Mathematische Zeitschrift, 29(1):436-460.

DOI: http://dx.doi.org/10.1007/BF01180541. 


\section{Saját publikációk}

\section{Idegen nyelvü}

\section{Referált szakmai folyóirat}

1) Csató, L. [2013a]: Ranking by pairwise comparisons for Swiss-system tournaments. Central European Journal of Operations Research, 21(4):783-803.

DOI: http://dx.doi.org/10.1007/s10100-012-0261-8.

2) Csató, L. [2014a]: A graph interpretation of the least squares ranking method. Social Choice and Welfare. Megjelenés alatt.

DOI: http://dx.doi.org/10.1007/s00355-014-0820-0.

\section{Tudományos könyvfejezet}

3) Csató, L. [2012a]: A pairwise comparison approach to ranking in chess team championships. In Fülöp P. (szerk.): Tavaszi Szél 2012 Konferenciakötet. Doktoranduszok Országos Szövetsége, Budapest, 514-519. o.

\section{Konferencia tanulmány, mühelytanulmány}

4) Csató, L. [2012b]: A paired comparisons ranking and Swiss-system chess team tournaments. Magyar Közgazdaságtudományi Egyesület VI. éves konferencia. URL: http://media. coauthors.net/konferencia/conferences/7/LLSM_ Buch_ranking_-.pdf.

5) Csató, L. [2014b]: Additive and multiplicative properties of scoring methods for preference aggregation. Corvinus Economics Working Papers 3/2014, Corvinus University of Budapest, Budapest.

URL: http://unipub.lib.uni-corvinus.hu/1562/.

\section{Egyéb}

6) Bozóki, S., Csató, L., Rónyai, L. és Tapolcai, J. [2014]: Robust peer review decision process. Kézirat. 


\section{Magyar nyelvü}

\section{Referált szakmai folyóirat}

7) Csató L. [2013c]: Rangsorolás páros összehasonlításokkal. Kiegészítések a felvételizői preferencia-sorrendek módszertanához. Közgazdasági Szemle, LX (12):1333-1353.

URL: http://unipub.lib.uni-corvinus.hu/1395/.

8) Csató L. [2013d]: Páros összehasonlításokon alapuló rangsorolási módszerek. Szigma, XLIV(3-4):155-198.

URL: http://unipub.lib.uni-corvinus.hu/1645/.

\section{Tudományos könyvfejezet}

9) Temesi J., Csató L. és Bozóki S. [2012] : Mai és régi idők tenisze. A nem teljesen kitöltött páros összehasonlítás mátrixok egy alkalmazása. In Solymosi T. és Temesi J. (szerk.): Egyensúly és optimum. Tanulmányok Forgó Ferenc 70. születésnapjára. Aula Kiadó, Budapest, 213-245. o.

URL: http://unipub.lib.uni-corvinus.hu/892/.

10) Bozóki S., Csató L. és Temesi J. [2013]: A Condorcet-paradoxon intranzitív dobókockákkal. In Matematikai közgazdaságtan: elmélet, modellezés, oktatás. Tanulmányok Zalai Ernőnek. Müszaki Kiadó, Magyar Minőség Társaság, Budapest, 41-53. o.

\section{Konferencia tanulmány, mühelytanulmány}

11) Csató L. [2011b]: Döntési módszerek és alternatív sakkeredmények. Magyar Közgazdaságtudományi Egyesület V. éves konferencia.

URL: http://media.coauthors.net/konferencia/conferences/5/MKE_ sakk.pdf.

12) Csató L. [2013b]: Páros összehasonlításon alapuló pontozási eljárások monotonitása: önkonzisztencia és önkonzisztens monotonitás. Adalékok a pontozási eljárások axiomatikus tárgyalásához. Mühelytanulmány (working paper), Budapesti Corvinus Egyetem, Budapest.

URL: http://unipub.lib.uni-corvinus.hu/1399/.

13) Csató L. [2013e]: Páros összehasonlításon alapuló pontozási eljárások szerkezeti tulajdonságai. Adalékok a pontozási eljárások axiomatikus tárgyalásához. Magyar Közgazdaságtudományi Egyesület VII. éves konferencia. 
14) Csató L. [2014c]: Svájci rendszerü sakk csapatversenyek rangsorolása. Mühelytanulmány (working paper), Budapesti Corvinus Egyetem, Budapest.

URL: http: //unipub.lib.uni-corvinus.hu/1604/.

\section{TDK dolgozat, szakdolgozat}

15) Csató L. [2009] : Külső egyensúlytalanságok a Baltikumban. BSc szakdolgozat, Budapesti Corvinus Egyetem, Közgazdaságtudományi Kar, Matematikai Közgazdaságtan és Gazdaságelemzés Tanszék.

URL: http://szd.lib.uni-corvinus.hu/3244/.

16) Csató L. [2010] : Tényleg csak matematika?: A korlátlan tengeralattjáró-háború szimulációs vizsgálata. TDK dolgozat, Budapesti Corvinus Egyetem, Gazdaságelemzés és gazdaságmodellezés II. szekció.

URL: http://szd.lib.uni-corvinus.hu/3014/.

17) Csató L. [2011a]: Döntési módszerek és alternatív sakkeredmények. TDK dolgozat, Budapesti Corvinus Egyetem, Gazdaságelemzés és gazdaságmodellezés szekció.

URL: http://szd.lib.uni-corvinus.hu/3256/.

18) Csató L. [2011c] : Globalizáció, jövedelemelosztás és input-output modellezés. MSc szakdolgozat, Budapesti Corvinus Egyetem, Közgazdaságtudományi Kar, Matematikai Közgazdaságtan és Gazdaságelemzés Tanszék.

URL: http://szd.lib.uni-corvinus.hu/3776/.

\section{Egyéb}

19) Csató L. [2006]: Cardano és a valószínüség. Természet Világa, 137(6) :CII-CIV. 